UNIVERSIDADE DE BRASÍLIA

INSTITUTO DE CIÊNCIAS SOCIAIS

DEPARTAMENTO DE SOCIOLOGIA

OS TUCANOS SE REPRODUZEM NA TERRA DA GAROA: UM ESTUDO ELEITORAL SOBRE A REELEIÇÃO DE GERALDO ALCKMIN EM SÃO PAULO

Jayane dos Santos Maia 
UNIVERSIDADE DE BRASÍLIA

INSTITUTO DE CIÊNCIAS SOCIAIS

DEPARTAMENTO DE SOCIOLOGIA

Jayane dos Santos Maia

Dissertação apresentada ao Departamento de Sociologia da Universidade de Brasília/UnB 


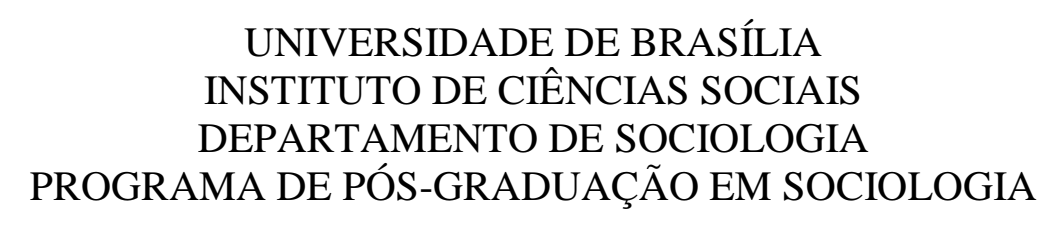

DISSERTAÇÃO DE MESTRADO

\title{
OS TUCANOS SE REPRODUZEM NA TERRA DA GAROA: UM ESTUDO ELEITORAL SOBRE A REELEIÇÃO DE GERALDO ALCKMIN EM SÃO PAULO
}

\author{
Jayane dos Santos Maia
}

Orientador: Doutor Luís Augusto Sarmento Cavalcanti de Gusmão (UnB)

Banca: Prof. Dr. Luís Augusto Sarmento Cavalcanti de Gusmão (UnB) Prof. ${ }^{a}$ Dr. ${ }^{a}$ Maria Filomena Pinto da Costa Coelho (UnB) Prof. ${ }^{a}$ Dr. ${ }^{a}$ Ana Cristina Murta Collares (UnB) 


\section{AGRADECIMENTOS}

Primeiramente, quero agradecer ao meu orientador, Prof. Gusmão, que durante minha estadia no mestrado e antes disso, quando fui sua aluna na graduação, sempre me ajudou, incentivando minhas ideias, dando conselhos imprescindíveis com relação às minhas pesquisas e tendo uma enorme paciência e disponibilidade em estabelecer longas conversas sobre os vários temas de estudo que rondavam minha cabeça e sobre minhas angústias acadêmicas e profissionais.

As suas recomendações referentes à escrita da dissertação e à sua estrutura foram essenciais para o melhoramento do trabalho e a elas se devem seus pontos positivos. O Prof. Gusmão com certeza muito contribuiu e ainda contribui para o meu crescimento intelectual por meio de suas formidáveis aulas e indicações de leitura. Nunca esquecerei as nossas discussões acaloradas sobre Gilberto Freyre em sala de aula e o que aprendi naquela ocasião.

Agradeço ao Prof. Gusmão a oportunidade de ter sido sua orientanda e fico extremamente honrada de ter trabalhado junto a um excelente professor e, além disso, a uma excelente pessoa, na qual me espelho para seguir minha carreira na academia.

Quero agradecer também à Prof. Ana Cristina por aceitar compor a banca examinadora bem como pelos conselhos e sugestões que me deu com relação à essa dissertação. Devo à professora os acertos principalmente da primeira parte desse trabalho, na qual faço uma análise quantitativa do meu objeto de estudo.

Os apontamentos da Prof. Ana, que é uma especialista excelente em técnicas e métodos quantitativos, foram de importância fundamental para que eu melhorasse a coleta e a análise dos dados. Suas recomendações e críticas com relação à organização da dissertação foram igualmente relevantes.

Agradeço ainda à Prof. Maria Filomena que aceitou de bom grado participar da banca examinadora dessa dissertação. Fico muito contente de tê-la como avaliadora do meu trabalho, pois a admiro muito como professora tanto por sua seriedade quanto por seu amplo e profundo conhecimento.

Tive a oportunidade de conhecê-la em uma disciplina ministrada por ela no Departamento de História da UnB e fiquei maravilhada com suas aulas, as quais me ajudaram muito em pensar na forma como eu iria reconstruir a história das três eleições de 
Geraldo Alckmin em São Paulo. Nesse sentido, a Prof. Filomena, por meio de suas aulas, foi uma figura essencial na construção dessa dissertação e o pouco contato que tive com ela fez total diferença tanto no resultado final do trabalho quanto no meu crescimento enquanto acadêmica.

Agradeço também à jornalista Julia Duailibi por sua imensa colaboração no início da minha pesquisa, atendendo-me com extrema disponibilidade. Seu trabalho primoroso acerca da política brasileira, em especial sobre a política paulista, aparece em várias partes dessa dissertação e foi essencial para o surgimento de minhas ideias.

Ao longo da feitura dessa dissertação muitos parentes e amigos foram importantes dando incentivo para a continuação da caminhada e alegrando meus dias. Quero agradecer imensamente ao meu pai, João, à minha mãe, Teresinha, e à minha irmã, Dayana, que são pessoas cruciais na minha vida e sempre, sem hesitação, ajudaram-me em tudo que eu precisei.

Quero, do fundo do meu coração, agradecer especialmente meu pai e minha mãe por sempre encorajarem meus estudos e meu crescimento. Sem a ajuda e o estímulo deles, eu não teria chegado até aqui. Quero agradecer também minha irmã, que sempre me escutou e aconselhou.

Meu namorado, Paulo César, também teve um papel importantíssimo tanto na minha vida pessoal quanto na minha jornada acadêmica. Foi companheiro e amigo nas alegrias e nas dificuldades que enfrentei no mestrado, além de me auxiliar com sua experiência e conhecimento, dando sugestões para a elaboração da pesquisa e incentivando ideias.

Também sou muito grata à minha sogra, Nacir, e ao meu sogro, Geraldo, pessoas boníssimas com as quais sei que posso contar e que torcem por mim e pelo meu sucesso.

Agradeço ainda à amizade de Camilla, Vanessa, Carol, Aisha e Adna, amigas que sempre desejaram meu crescimento e se entusiasmaram com meu objeto de pesquisa nessa dissertação.

Agradeço também à Capes pelo incentivo à pesquisa por meio de seu programa de bolsas. Ao Departamento de Sociologia da UnB que me acolheu para a realização do mestrado. Aos professores doutores da UnB, da UFPR e da UFSCar que colaboraram para o meu crescimento acadêmico e profissional. Às secretárias da pós-graduação, Patrícia, 
Ana Paula e Gabriella, que sempre atenderam minhas solicitações com muita paciência e empenho. Ao colega Paulo Moreira que, de forma muito competente, me ajudou muitíssimo com a minha pesquisa. Ao novo amigo, Sidney Wanderley, que me auxiliou com a revisão do texto. Por fim, mas não menos importante, agradeço a Deus, que me permitiu terminar essa dissertação com saúde e que colocou em meu caminho pessoas que me ajudam e torcem por mim. 
Monsieur Diderot, ouvi atentamente e com o maior prazer todas as inspirações de sua mente brilhante. Mas todos os seus princípios grandiosos, que compreendo muito bem, funcionam esplendidamente nos livros e muito mal na prática. Em seus planos de reforma, você se esquece da diferença entre nossas duas posições: você trabalha apenas no papel, que aceita tudo, é suave e flexível, e não oferece obstáculo, nem à imaginação nem à pena, ao passo que eu, pobre imperatriz, trabalho na pele humana, muito mais sensivel e melindrosa.

- Catarina, a Grande, última mulher a governar a Rússia (1762-1796). 


\section{SUMÁRIO}

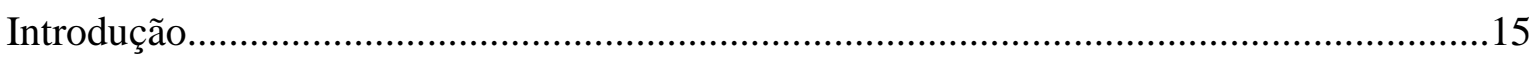

Apresentação e importância do problema de pesquisa.....................................................15

Capítulo 1 - Voto e indicadores socioeconômicos municipais nas eleições do tucano

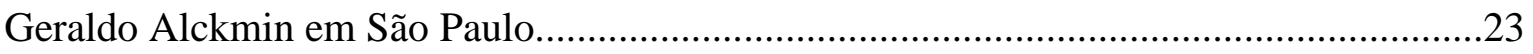

1.1. O papel das clivagens sociais nas arenas política e eleitoral......................................23

1.2. Hipóteses para explicação do sucesso de Alckmin em São Paulo: voto e status

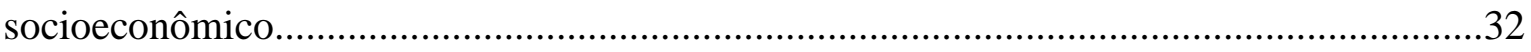

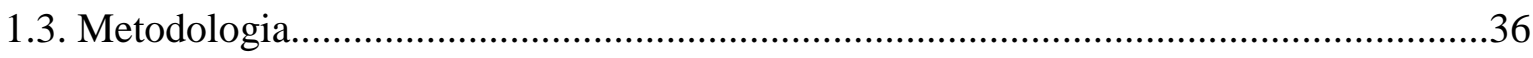

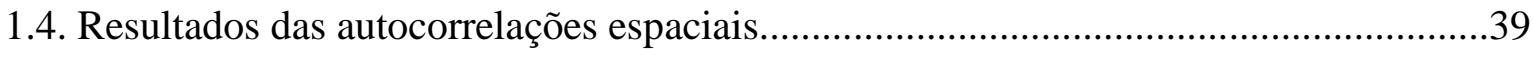

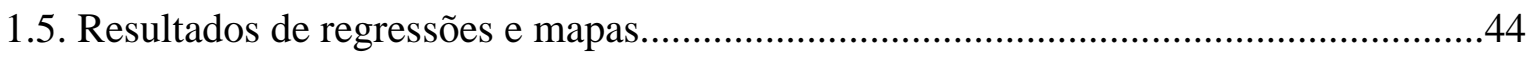

Capítulo 2 - O PSDB paulista: a hegemonia tucana na terra da garoa................................60

2.1. A criação do Partido da Social Democracia Brasileira e o reduto do partido em São Paulo.

2.2. O contexto político de São Paulo na década de 90: a pavimentação por Mário Covas do caminho de Alckmin..

2.3. Eleições 2002: a vitória de Geraldo Alckmin, o pupilo e herdeiro político de Covas.

2.4. O decorrer do primeiro mandando como governador e a derrota para Presidente em 2006.

2.5. A saga para o retorno de Alckmin: derrota consecutiva em 2008, secretário em 2009 e

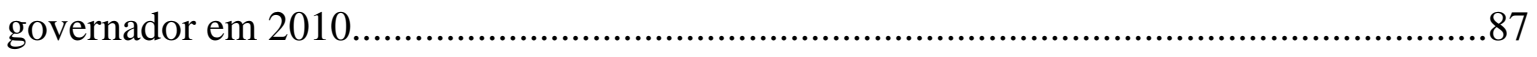

2.6. A quase unanimidade dos municípios na reeleição de Alckmin em 2014....................93

2.7. Alianças e eleições: a modelagem da disputa pelas elites políticas.............................100

2.8. A importância dos aliados para as vitórias tucanas em São Paulo...............................102

3. Capítulo 3 - A importância da imagem de Alckmin para aliados e eleitores.................111

3.1. A centralidade da imagem do candidato nas eleições e suas causas...........................111

3.2. Quem é o político Geraldo Alckmin? O bom moço metódico e paciente.....................113

4. Capítulo 4 - Antipetismo em SP? Dificuldades do Partido dos Trabalhadores como

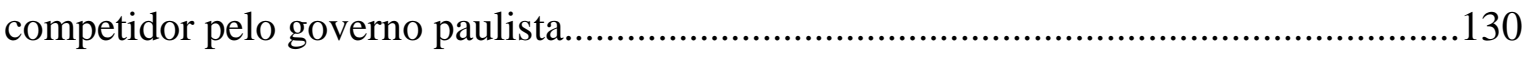

4.1. Breve história do partido e trajetória da luta pelo governo paulista............................130 
Considerações finais

Referências bibliográficas

\section{LISTA DE TABELAS}

Tabela 1 - Variáveis independentes utilizadas nos modelos, relacionadas por ano eleitoral.

Tabela 2 - Valores do índice de Moran I (I) para as proporções de voto em Alckmin, em 2002 ( $1^{\circ}$ e $2^{\circ}$ turnos), 2010 e 2014.

Tabela 3 - Resultados dos modelos lineares generalizados (GLM) por ano eleitoral.

Tabela 4 - Porcentagens de votos válidos para o governador eleito em São Paulo em 1998, Mário Covas (PSDB), nos municípios do Vale do Paraíba, referentes ao $1^{\circ}$ turno.

Tabela 5 - Resultado da eleição em 2014 para governador em São Paulo. .98

Tabela 6 - Bancadas eleitas na Assembleia Legislativa de São Paulo (19942014)

Tabela 7 - Valor do total de emendas liberadas pelo governo de São Paulo entre 2007 e outubro de 2011 por partido (em milhões de reais).

Tabela 8 - Resultado parcial (em 19/11/1982) da eleição em 1982 para governador em São Paulo.

Tabela 9 - Resultado da eleição em 1986 para governador em São Paulo.

Tabela 10 - \% de votos válidos recebida pelos quatro primeiros colocados no primeiro turno para o governo de SP, por região.

Tabela 11 - Resultado do primeiro turno da eleição em 1998 para governador em SP.

Tabela 12 - \% de votos válidos recebidos por Serra (PSDB) e Mercadante (PT) por região administrativa do estado de SP. 
Tabela 13 - Desempenho do Partido dos Trabalhadores na disputa para o governo de São Paulo (1982-2014).

\section{LISTA DE GRÁFICOS}

Gráfico 1 - Porcentagens do valor total de emendas (em R\$) destinadas à base do governo e à oposição na Assembleia Legislativa de SP entre 2007 e 2011. 108

\section{LISTA DE MAPAS}

Mapa 1: votação de Geraldo Alckmin (PSDB) para governador em 2002, por município SP.

Mapa 2: votação de Geraldo Alckmin (PSDB) para governador em 2010, por município SP.

Mapa 3: votação de Geraldo Alckmin (PSDB) para governador em 2014, por município SP.

Mapa 4: relação entre anos de estudo (2000) e \% de votos válidos para o governador eleito em São Paulo (2002), por município - SP.

Mapa 5: relação entre IDHM renda (2002) e \% de votos válidos para o governador eleito em São Paulo (2002), por município - SP

Mapa 6: relação entre índice de Gini (2000) e \% de votos válidos para o governador eleito em São Paulo (2002), por município - SP

Mapa 7: relação entre índice de envelhecimento (2002) e \% de votos válidos para o governador eleito em São Paulo (2002), por município - SP.

Mapa 8: relação entre anos de estudo (2010) e \% de votos válidos para o governador eleito em São Paulo (2010), por município - SP.

Mapa 9: relação entre IDHM renda (2010) e \% de votos válidos para o governador eleito em São Paulo (2010), por município - SP

Mapa 10: relação entre índice de Gini (2010) e \% de votos válidos para o governador eleito em São Paulo (2010), por município - SP

Mapa 11: relação entre índice de envelhecimento (2010) e \% de votos válidos para o governador eleito em São Paulo (2010), por município - SP.

Mapa 12: relação entre \% de empregos formais (2010) e \% de votos válidos para o governador eleito em São Paulo (2010), por município - SP 
Mapa 13: relação entre \% de famílias beneficiárias do Programa Bolsa Família (2010) e \% de votos válidos para o governador eleito em São Paulo (2010), por município - SP.....

Mapa 14: relação entre IPRS escolaridade (2012) e \% de votos válidos para o governador eleito em São Paulo (2014), por município - SP.

Mapa 15: relação entre IPRS riqueza (2012) e \% de votos válidos para o governador eleito em São Paulo (2014), por município - SP

Mapa 16: relação entre \% de famílias beneficiárias do Programa Bolsa Família (2013) e \% de votos válidos para o governador eleito em São Paulo (2014), por município SP.

Mapa 17: relação entre índice de envelhecimento (2014) e \% de votos válidos para o governador eleito em São Paulo (2014), por município - SP

Mapa 18: relação entre \% de empregos formais (2014) e \% de votos válidos para o governador eleito em São Paulo (2014), por município - SP 


\section{LISTA DE SIGLAS}

\section{Partidos Brasileiros}

ARENA - Aliança Renovadora Nacional

MDB - Movimento Democrático Brasileiro

PCB - Partido Comunista do Brasil

PCdoB - Partido Comunista do Brasil

PCO - Partido da Causa Operária

PDC - Partido Democrata Cristão

PDS - Partido Democrático Social

PDT - Partido Democrático Trabalhista

PFL - Partido da Frente Liberal

PMDB - Partido do Movimento Democrático Brasileiro

PP - Partido Progressista

PPB - Partido Progressista Brasileiro

PPR - Partido Progressista Renovador

PPS - Partido Popular Socialista

PSDB - Partido da Social Democracia Brasileira

PSP - Partido Social Progressista

PT - Partido dos Trabalhadores

PTB - Partido Trabalhista Brasileiro

PTN - Partido Trabalhista Nacional

UDN - União Democrática Nacional

PV - Partido Verde

\section{Partidos Portugueses}

CDS - Partido do Centro Democrático Social

PCP - Partido Comunista Português

PDS - Partido Social Democrata 


\section{RESUMO}

MAIA, Jayane. Os tucanos se reproduzem na terra da garoa: um estudo eleitoral sobre a reeleição de Geraldo Alckmin em São Paulo. 2016. 143 páginas. Dissertação (Mestrado) - Departamento de Sociologia, Universidade de Brasília, Brasília, 2016.

O sucesso eleitoral do PSDB e de seus candidatos no governo do estado de São Paulo vem de longa data. Este estudo visa contribuir com a discussão acerca da manutenção do poder por esse partido no referido estado. Para isso, foram estudadas as vitórias de Geraldo Alckmin, que venceu três $(2002,2010$ e 2014) das seis eleições ocorridas desde 1994, ano em que Mário Covas conquistou o primeiro mandato dos tucanos em SP. A fim de avaliar os fatores determinantes das vitórias de Alckmin no estado, foram trabalhadas quatro hipóteses de pesquisa. A primeira foi a de que indicadores socioeconômicos municipais interferem de algum modo na proporção de votos obtida nos municípios pelo candidato psdebista, aumentando-a ou diminuindo-a. A partir da elaboração de três modelos logísticos lineares generalizados (GLM) - um para cada eleição -, aferiu-se a relevância de índices como anos de estudo e Gini na variação dos dados relativos às proporções de votos. A segunda hipótese procurou, a partir da reconstrução do contexto de cada eleição, examinar a importância eleitoral das alianças firmadas pelo PSDB em SP, acreditando-se que a coligação com partidos e lideranças de peso pode beneficiar o partido e seus candidatos. A facilidade de Alckmin em reunir aliados, sendo atencioso, e de cativar eleitores, ajudado pela imagem de bom moço apegado à família, certamente o beneficia, e esse foi o ponto abordado na terceira hipótese. Por fim, a quarta hipótese trabalhou a ideia de que o sucesso eleitoral do PSDB em São Paulo é resultado ainda da dificuldade do Partido dos Trabalhadores (PT), atualmente o principal partido de oposição, em estabelecer candidaturas viáveis aos olhos do eleitorado, o que é agravado pela disseminação de um sentimento antipetista por meios de comunicação possuidores de audiência significativa no estado. Concluiu-se que, embora os modelos estatísticos de cada ano eleitoral tenham apontado como significantes para as votações de Alckmin alguns índices socioeconômicos - como anos de estudo, índice de envelhecimento e Gini -, eles explicaram pouco da variação total das proporções de votos. Isso demonstrou que outros fatores contextuais, como os apresentados nas demais hipóteses, não relacionados à estrutura socioeconômica, repercutem no sucesso eleitoral de Alckmin em São Paulo.

Palavras-chave: eleição, governador, São Paulo, Alckmin, PSDB. 


\begin{abstract}
MAIA, Jayane. Toucans reproduce in the Land of Drizzle: an electoral study on the reelection of Geraldo Alckmin in São Paulo. 2016. 143 pages. Master Dissertation Department of Sociology, University of Brasília, Brasília, 2016.

The electoral success of PSDB and its candidates for the governorship of the state of São Paulo goes back a long way. This study aims to contribute to the discussion regarding that party's maintenance of political power in that state. In order to do so, we studied the victories of Geraldo Alckmin, who won three (2002, 2010, and 2014) of the six elections that have taken place since 1994, the year in which Mário Covas earned toucans their first term of office in the state of São Paulo. In order to assess the determining factors for Alckmin's state victories, we worked with four research hypotheses. The first hypothesis is that local socioeconomic indicators in some way affect the proportion of votes obtained municipally by the PSDB candidate, increasing or decreasing it. From the formulation of three generalized linear logistic models (GLM) - one for each election -, we assessed the relevance of indicators such as years of education and Gini coefficient to the variation in data relating to vote proportion. By reconstructing the context of each election, the second hypothesis intends to examine the electoral importance of the alliances that PSDB has consolidated in the state of São Paulo, believing that the coalition with heavyweight parties and leaderships can benefit the party and its candidates. The easiness with which Alckmin has gathered allies, by being attentive, and captivated voters, with the help of a wholesome, family-oriented guy image, certainly benefits him, and that is what the third hypothesis addresses. Finally, the fourth hypothesis works on the idea that PSDB's electoral success in São Paulo is, furthermore, a result of the difficulty PT (Worker's Party), currently the major oppositional party, has in establishing candidacies that are viable in the eyes of voters, a difficulty aggravated by the dissemination of an anti-PT sentiment by media of significant audience in that state. We have concluded that even though statistical models of each electoral year indicated some socioeconomic indicators - such as years of education, aging index, and Gini coefficient - as significant to Alckmin's votes, they clarify very little about the total variation in vote proportion. That demonstrated that other contextual factors, such as those presented by the other hypotheses and unrelated to socioeconomic structure, do have an impact on Alckmin's electoral success in São Paulo.
\end{abstract}

Keywords: election, governor, São Paulo, Alckmin, PSDB. 


\section{INTRODUÇÃO}

\section{Apresentação e importância do problema de pesquisa}

Antes de tratar de um aspecto específico - seja política, economia, cultura ou religião - de um país, federação, estado, região ou distrito, cabe ao pesquisador questionarse acerca do motivo da escolha, em primeiro lugar, do seu objeto de estudo, e depois, do seu recorte espacial e temporal, na tentativa de assegurar-se sobre o terreno no qual está pisando. Nesse sentido, pode-se indagar: por que Karl Marx se preocupou em analisar a conjuntura política e social da França entre 1848 e 1850? Ou por qual razão Gilberto Freyre se debruçou sobre a cultura do norte açucareiro especialmente entre os séculos XVIII e XIX? É certo que quaisquer aspectos da vida e das relações humanas em qualquer tempo são passíveis de ser estudados, mas certamente alguns temas se impõem - como diz Gustave Flaubert em uma de suas correspondências - ao olhar do pesquisador, a depender de sua área e interesses. A contextualização do objeto se liga à justificativa de sua escolha, e é baseado nesse apontamento que se desenvolverá este trabalho.

São Paulo hoje se destaca por vários aspectos. Trata-se do estado que, atualmente, possuindo o maior parque industrial entre todos os estados, é responsável pela maior participação no PIB nacional. Destaca-se ainda por ter uma população diversa, advinda de diferentes origens: migrantes de outros estados brasileiros e imigrantes de vários países ${ }^{1}$. É, portanto, o estado que possui a maior heterogeneidade populacional.

Também seguindo a via superlativa, porém negativa, SP tem a maior população carcerária do país e a segunda maior taxa de encarceramento (497,4/100 mil habitantes), segundo dados do Ministério da Justiça. Sendo o estado mais populoso do Brasil, com mais de 40 milhões de habitantes, possui consequentemente o maior colégio eleitoral, com mais de 31 milhões de eleitores. Esse número com certeza faz com que o estado seja de extrema importância para os candidatos à Presidência da República e, por isso, mereça atenção especial, principalmente em períodos eleitorais.

\footnotetext{
${ }^{1}$ Segundo dados da Pesquisa Nacional de Amostras por Domicílio (PNAD) relativos ao ano de 2013, São Paulo é o estado que possui o maior número de migrantes, com mais de 10 milhões. Já de acordo com o Sistema Nacional de Cadastramento e Registro de Estrangeiros (Sincre), mais da metade dos estrangeiros registrados no Brasil estão no estado de São Paulo, o que corresponde a 561.912 imigrantes. A Polícia Federal registrou que portugueses, bolivianos e japoneses somam 177.908 habitantes apenas na capital paulista. Eles formam, nessa ordem, as três maiores comunidades de imigrantes na cidade.
} 
A significância do estado de São Paulo, que vem desde os tempos coloniais, estende-se até hoje em diferentes aspectos, entre eles, na política nacional. Atualmente, o estado também chama atenção pela característica que une todos os seus governadores eleitos desde o pleito de 1994. Desde esse ano, com a vitória de Mário Covas, candidatos do Partido da Social Democracia Brasileira (PSDB) ocupam o Palácio dos Bandeirantes. Em 2018, o PSDB, ao que tudo indica, completará 24 anos à frente do governo do estado ${ }^{2}$, tendo em vista a eleição em primeiro turno de Geraldo Alckmin nas eleições de 2014. São Paulo se destaca ainda pelo maior número de mandatos de um mesmo partido no governo estadual. Perto dele há apenas o Acre, onde candidatos do principal rival, o Partido dos Trabalhadores (PT), vencem as eleições para o governo acreano desde 1998.

O PSDB, hoje, possui grande visibilidade nacional, graças, em partes, ao seu papel de principal opositor do governo petista. Segundo dados do Tribunal Superior Eleitoral (TSE), em 2015 o partido foi o quarto colocado em número de filiados no Brasil, com 1.409.515 eleitores inscritos, estando atrás de PMDB, PT e PP. Só em São Paulo o partido, até abril de 2016, possuía 302.966 filiados, ocupando também a quarta colocação em número de inscritos, sendo, entre os cinco primeiros da lista, o partido que mais aumentou em filiados em São Paulo desde dezembro de 2015.

Nas últimas eleições, obteve a vitória para o governo de cinco estados, os quais somam, juntos, uma população que representa mais de 1/3 do total de habitantes do país. Criado em 1988, no período da Assembleia Nacional Constituinte, o PSDB foi formado por dissidentes do PMDB como Mário Covas, Fernando Henrique Cardoso, André Franco Montoro, Luiz Carlos Bresser-Pereira, Geraldo Alckmin, José Serra e José Richa. Entre os 116 fundadores do partido, segundo a ata da reunião de fundação, 35 eram paulistas, o que correspondia à maioria de representantes de um estado.

São Paulo é, portanto, considerado o berço do PSDB, por ser tanto o seu local de nascimento como a origem de grande parte das suas principais lideranças criadoras e futuras. Entre essas últimas está atualmente o governador de São Paulo, Geraldo Alckmin, o qual, embora estivesse presente desde a fundação do partido, somente anos depois adquiriu a expressividade política que possui hoje estadual e nacionalmente. Personagem

\footnotetext{
${ }^{2}$ Mais detalhadamente, o PSDB poderá completar à frente do governo de SP 23 anos e três meses. Isso porque, em 2006, houve uma interrupção de nove meses, quando Geraldo Alckmin deixou o governo para disputar a eleição presidencial. Em seu lugar assumiu o seu vice, Claudio Lembo, filiado ao então Partido da Frente Liberal (PFL).
} 
importante na política paulista, Alckmin destaca-se por ser o candidato tucano que mais ocupou o cargo de governador de SP: foi eleito em 2002, 2010 e 2014. Foi ainda duas vezes vice-governador, com a vitória em 1994 e 1998 de Mário Covas (seu principal cabo eleitoral), tendo-o substituído a partir de março de 2001, após sua morte. Alckmin iniciou sua carreira política como vereador em Pindamonhangaba, sua cidade natal, e se pode dizer que as suas vitórias para o Executivo estadual paulista certamente contribuíram para o seu estabelecimento como uma das lideranças atuais do PSDB.

Perguntando-se sobre o que leva o PSDB a se reeleger continuadamente para o governo de São Paulo e mais especificamente sobre quais seriam os motivos que corroboram de forma positiva para o ganho de votos por Alckmin e sustentam sua eleição, analisar-se-ão aqui especificamente as eleições nas quais ele foi o vitorioso para o Executivo paulista nos anos de 2002, 2010 e 2014. Intenta-se tornar inteligíveis as sucessivas vitórias do atual governador de SP e de seu partido, considerando-se quatro aspectos, sabendo que, numa democracia competitiva, é mais provável que a soma destes interfira no sucesso eleitoral: i) a influência do PSDB e das alianças estabelecidas; ii) a importância da figura de Alckmin; iii) a dificuldade do Partido dos Trabalhadores (PT) de se colocar como um concorrente viável para o governo de SP perante os eleitores paulistas; e, iv) o peso das bases eleitorais, caso essas realmente existam no estado.

Com relação ao último aspecto, questionando-se em um primeiro momento a opinião dos autores que apontam para o total enfraquecimento das clivagens sociais na escolha do voto (DALTON, 1996; CLARK, LIPSET, REMPEL, 2001; DOGAN, 2001), o peso das bases eleitorais foi avaliado a partir de indicadores socioeconômicos municipais associados à votação recebida pelo tucano Geraldo Alckmin nas eleições de 2002, 2010 e 2014, visando à captação, caso existam, de padrões socioeconômicos e geográficos relativos à distribuição de votos em Alckmin nos municípios paulistas.

A investigação da possibilidade de haver um padrão no perfil dos votantes em Alckmin durante os anos em que ele foi eleito é uma forma de medir até que ponto aspectos como educação, renda e idade de uma população interferem e pesam na votação dada a um candidato e a seu partido. A identificação de um reduto eleitoral ou de uma base de apoio que favoreça em São Paulo a vitória tucana é importante na medida em que mostra qual ou quais grupo(s) tende(m) a preferir os candidatos psdebistas ou a rejeitar as opções dadas contra o governo. 
Tendo em vista a literatura que associa características sociais e econômicas ao tipo de comportamento político dos votantes no contexto eleitoral (LIPSET, ROKKAN, 1967; LISI, 2011), bem como os estudos que veem os partidos políticos como organizações capazes de mobilizar clivagens sociais e representar grupos sociais (LISI, 2011; HOUT, BROOKS, MANZA, 2001), avaliou-se se variáveis socioeconômicas e a variável política referente ao partido do prefeito repercutiram nas três votações do governador.

Levando em consideração também a literatura sobre geografia eleitoral, que aponta para a existência de bases eleitorais dos candidatos centradas em determinados espaços geográficos (SOARES, TERRON, 2008; STORNI, 2010), verificou-se se, em São Paulo, essa alegação se ajusta à distribuição de votos em Alckmin, a evidenciar um padrão entre eleições e, portanto, bastiões com os quais o governador pode contar para seu êxito eleitoral. Em termos mais específicos, investigou-se a afirmativa de que Alckmin tem maior apoio eleitoral no interior de São Paulo do que na região metropolitana do estado.

Observou-se, por meio de regressões múltiplas, se variáveis socioeconômicas municipais interferiram de alguma maneira na votação de Alckmin, aumentando-a ou diminuindo-a. Foram definidas como hipóteses que o aumento da idade, da renda, da educação e do número de empregos formais no município favoreceria uma distribuição crescente da proporção de votos em Alckmin no município. Isto é, quanto maiores forem a educação e a riqueza do município e menor for a desigualdade de renda entre a população, acreditou-se haver uma tendência para o crescimento da votação tucana. Ao passo que o recebimento do programa social Bolsa Família, supôs-se, tenderia a diminuí-la, o que também se acreditou que ocorra quando o partido do prefeito no município é da oposição ao governo do estado.

Nota-se que tais hipóteses se baseiam em assertivas formuladas por autores diversos que agregam a literatura sobre o tema, o que possibilita vários questionamentos e revisões sobre aquilo que já foi colocado. Embora parte dos teóricos que estudam eleições, tanto em âmbito nacional quanto internacional, apontem as clivagens sociais como fracos preditores eleitorais (INGLEHART, 1984; NIEWBEERTA, 2001), alguns estudos, apesar de confirmarem tal afirmação, identificam alguns padrões que relacionam características socioeconômicas e partidos (LISI, 2011). 
Marco Lisi (2011), ao tratar do caso dos partidos portugueses, aponta, por exemplo, que maiores índices de envelhecimento e nível educacional mais elevado estão ligados ao voto nos partidos de centro-direita, os quais, segundo ele, têm maior capacidade de atrair, em comparação com os partidos considerados de esquerda, indivíduos de quadros dirigentes como empresários e profissionais liberais. Em termos de composição socioprofissional, as bases de apoio dos partidos de esquerda em Portugal são formadas mais significativamente por trabalhadores assalariados.

No entanto, ainda que índices sociais e econômicos possam ser associados à tomada de decisão do eleitor e, por sua vez, aos resultados eleitorais, a fragilidade dessa relação existe, conforme se verá posteriormente. A explicação estrutural do voto, baseada em presumidas variáveis independentes de alcance transcontextual, revela-se insuficiente para lidar com a complexidade das eleições e de seus resultados e abre espaço para a procura de variáveis contextuais, que se ligam às dinâmicas e estratégias político-eleitorais.

A importância de se analisar o contexto numa explicação causal é sublinhada por Anthony Giddens para quem "a história é a estruturação de eventos no tempo e no espaço mediante a interação contínua de agência e estrutura, a interconexão da natureza mundana da vida diária com as formas institucionais que se estendem sobre imensos períodos de tempo e de espaço" (GIDDENS, 2003, p. 427). É nesse sentido que os demais aspectos mencionados anteriormente colocam-se como possíveis influências, não excludentes, para o sucesso eleitoral de Alckmin e de seu partido nas eleições para o governo de São Paulo; são eles que se somarão à perspectiva dos indicadores socioeconômicos, na tentativa de complementá-la.

No que se refere à análise da influência do PSDB nas eleições de Alckmin, buscou-se compreender qual o peso do partido e de suas alianças na montagem e no desenrolar da competição eleitoral. A compreensão da história política recente do estado requer que se dê atenção a algumas figuras que foram ou ainda são responsáveis por escrever parte dessa narrativa, mediante a sua inserção no jogo político e nas dinâmicas de poder, e ainda por meio da construção de redes de relações políticas que viabilizam estratégias contra os opositores. Geraldo Alckmin, sem dúvida, é uma das figuras que devem ser estudadas quando se trata de entender o contexto da política paulista. Mas não só ele: também as pessoas ligadas a ele que o ajudaram de alguma forma durante sua 
trajetória - inclusive aliados -, bem como os seus adversários, todos responsáveis por construir o contexto no qual se dará a competição eleitoral.

A partir disso, pretende-se apresentar a literatura que não trilha o caminho pessimista no qual os partidos foram comumente colocados nos últimos anos (KINZO, 2005; NICOLAU, 2006) e colocar em discussão a bibliografia que considera o êxito nas eleições como advindo quase totalmente da imagem que tem o candidato perante os eleitores (SAMUELS, 1997). Embora se acredite que, nos últimos anos, os trabalhos tenham dado peso demasiado à figura do candidato, excluindo outros aspectos importantes, não se nega a relevância daquele que se apresenta perante os eleitores; por isso, a imagem de Geraldo Alckmin é destacada aqui visando à elucidação das suas vitórias. Com efeito, atenta-se para o fato de que aqui a imagem do político será conjugada com o papel da estrutura partidária e das alianças do PSDB em São Paulo.

Outro aspecto avaliado foi a dificuldade que o Partido dos Trabalhadores tem tido nas últimas eleições em colocar seus candidatos como opções viáveis para o governo de São Paulo. Das seis eleições que ocorreram desde 1994, os candidatos petistas ficaram em metade delas apenas em terceiro lugar. Nas eleições de 2002 e 2010, os concorrentes de Alckmin, José Genoíno (PT) e Aloisio Mercadante (PT), respectivamente, ficaram em segundo lugar na disputa; apenas Genoíno alcançou o segundo turno. Já em 2014, Alexandre Padilha (PT) foi o terceiro colocado, ficando atrás do candidato peemedebista Paulo Skaf e contabilizando uma diferença negativa de mais de 8 milhões de votos em relação ao vitorioso Geraldo Alckmin, a maior diferença entre os rivais desde 1994.

Não obstante o berço do PT ser o estado de São Paulo, especialmente a região do ABC, e ainda o fato de a Grande São Paulo formar o que a imprensa chama de “cinturão vermelho", tendo em vista o sucesso eleitoral petista na localidade, São Paulo é conhecido por ser um estado com um significativo sentimento antipetista, sendo os paulistas - não todos, claro - os precursores de manifestações contra o partido que ocupa atualmente, de modo oficial, o governo federal.

Uma vez que o PT é tido hoje como principal opositor do PSDB, disputa essa que, no caso de São Paulo, transpõe-se do âmbito nacional, embora nem sempre tenha sido ele o principal concorrente no estado, é provável que o sucesso eleitoral dos tucanos corresponda também à debilidade do PT - assim como dos outros partidos - de se contraporem ao PSDB, mostrando-se como alternativas viáveis ao eleitorado. Assumindo- 
se como verdadeira essa hipótese, pode-se dizer que pelo menos parte dos votos nos candidatos psdebistas seria não necessariamente de preferência, mas de rejeição aos outros partidos e candidatos que disputam a eleição.

Por se saber da centralidade do período eleitoral no contexto democrático bem como da peculiaridade da dinâmica política que existe em cada estado brasileiro, entendese que a análise das eleições de Geraldo Alckmin para governador de São Paulo contribuirá com a discussão acerca da participação e permanência tanto do PSDB quanto do político em questão no governo do estado e, de modo mais geral, colaborará com os estudos sobre reeleição no Brasil.

Ao tratar de eleições é praticamente impossível não mencionar aqueles que são responsáveis por elas, isto é, os eleitores. Portanto, serão feitas considerações referentes ao comportamento eleitoral dos votantes, na medida em que isso contribua tanto para um melhor esclarecimento das questões que estão sendo abordadas, quanto para discussões que possam ser aprofundadas em estudos posteriores. Nesse sentido, teve-se como objetivo não só apresentar as limitações dos indicadores socioeconômicos referentes à população na explicação do resultado eleitoral, mas também colocar em pauta um conjunto de fatores relativos à conjuntura política pré-eleitoral e durante as eleições, e avaliá-los como possíveis fundamentos, não excludentes, do sucesso eleitoral do partido e do candidato no estado de São Paulo.

Visando contribuir, ainda que minimamente, com as pesquisas acerca do contexto político de São Paulo no que se refere ao Poder Executivo estadual, o trabalho tem como foco três eleições específicas, mas constituiria um equívoco não relacioná-las ao contexto político-eleitoral mais amplo, sabendo que o jogo político é contínuo, não sendo iniciado e finalizado quando começa e termina uma eleição, bem como que o sucesso eleitoral de um partido e de seu candidato pode se relacionar à ausência no pleito de certas forças políticas, que estavam presentes em períodos anteriores, e/ou ao grau de viabilidade das demais candidaturas.

A organização das forças políticas, que estão sempre em movimento, interfere na escolha do eleitor, e a relação entre esse aspecto e as clivagens sociais também será abordada. Com efeito, tentou-se, por meio da formulação, da discussão e da verificação empírica de hipóteses, investigar mais a fundo quatro aspectos que podem estar ligados à inserção exitosa de Alckmin e de seu partido no governo de SP. Além disso, por se 
acreditar que uma vitória eleitoral é consequência da conjunção de diversos fatores, investigou-se em que medida a movimentação dos atores políticos e outras variáveis políticas se associam às clivagens sociais e/ou as substituem na decisão do voto pelo eleitor.

No campo da sociologia eleitoral, o estudo das reeleições e da dinâmica política que as envolve ainda carece de contribuições, o que também ocorre com os estudos acerca do ambiente político dos governos estaduais. Pesquisas relacionadas ao Poder Legislativo e aos governos municipais ainda sobressaem, juntamente com trabalhos que tratam do Poder Executivo federal (LIMONGI; GUARNIERI, 2015; JACOB; HEES; WANIEZ; BRUSTLEIN, 2003; SOARES; TERRON, 2008; CERVI, 2009; ALMEIDA; LOPEZ, 2012).

Não havendo estudos significativos publicados sobre questões políticas e eleitorais que abarquem o estado de São Paulo, com exceção dos trabalhos de Roma (2000), Braga (2008) e Storni (2010), as eleições municipais da capital do estado são protagonistas em boa parte dos trabalhos (MARQUES, 2003; LIMONGI; MESQUITA, 2011; ROCHA, 2012). Talvez se possa justificar a preferência pelo município em detrimento do estado tendo em vista a enorme complexidade que é tratar das eleições para governador num estado que tem o maior número de municípios e tantas diversidades. Há, portanto, uma lacuna considerável quando se trata da eleição do governo dos estados e, nesse sentido, este trabalho aborda também esse aspecto. 


\section{CAPÍTULO 1 - VOTO E INDICADORES SOCIOECONÔMICOS MUNICIPAIS NAS ELEIÇÕES DO TUCANO GERALDO ALCKMIN EM SÃO PAULO}

\subsection{O papel das clivagens sociais nas arenas política e eleitoral}

A associação entre indicadores socioeconômicos e resultados eleitorais é, há algum tempo, uma prática comum entre os estudiosos que pretendem verificar quais as bases de apoio de um ou outro candidato. A ideia da existência de um reduto eleitoral que apoie um político ou um partido e que seja decisivo para seu sucesso é defendida por muitos e pode se basear em padrões de voto encontrados em localidades geográficas bem como em populações que compartilham características semelhantes.

Essa perspectiva pressupõe que as representações políticas produzidas pelos eleitores são influenciadas - e não necessariamente determinadas - pelo grupo social e/ou geográfico ao qual pertencem. Entendendo-se por representação política a forma como o indivíduo vê tanto a atividade política como os encarregados por ela, o comportamento eleitoral se ligaria ao lugar de onde esse indivíduo pensa e fala, lugar que, afetado por diferentes fatores, sejam eles sociais, econômicos ou culturais, reflete nas experiências e, por consequência, no modo como se percebe o mundo.

Giddens, ao trabalhar a relação entre geografia e sociologia, aponta que o contexto existe no tempo e no espaço e que "na geografia humana, as formas espaciais são sempre formas sociais" (GIDDENS, 2003, p. 433), de modo que certamente “(...) os contextos localizados da vida cotidiana" (GIDDENS, 2003, p. 432) são mais importantes para fazer aflorar um sentimento de pertencimento do que aqueles advindos de locais mais abrangentes como países, regiões etc. Para o autor, "um senso de lugar parece ser de grande importância na sustentação da segurança ontológica, precisamente porque fornece um elo psicológico entre a biografia do indivíduo e os locais que constituem os cenários dos percursos tempo-espaço onde o indivíduo se movimenta" (GIDDENS, 2003, p. 432).

É nesse sentido que a análise sociológica do comportamento político deve se abster de explicações homogêneas ou suprassociais do voto e atentar para a relevância eleitoral de fatores palpáveis na sociedade, como é o caso dos estratos socioeconômicos, os quais “(...) constituem agrupamentos espaciais que se distribuem diferencialmente entre 
bairros de uma cidade em função das possibilidades de acesso a habitações de certo padrão, a serviços de infraestrutura etc." (LAMOUNIER, 1975, p. 22).

Teoricamente, os partidos políticos são essenciais em uma democracia devido à função que exercem de representação da população seja nas arenas eleitoral ou legislativa. Basicamente, de acordo com essa perspectiva, a vida útil das organizações partidárias está atrelada à sua capacidade de agregar interesses e fazê-los refletir politicamente. Segundo Marco Lisi (2011), os partidos, ao possuírem uma dimensão interna cooperativa baseada na lógica organizativa de criação de identidades, exercem a função de mobilização eleitoral, intermediando o contato entre cidadãos e esfera pública, embora, hoje, não sejam as únicas entidades que exerçam esse papel e existam controvérsias quanto à sua efetividade. Compõe-se, assim, o sistema partidário, o qual, ao mesmo tempo que é influenciado e influencia o sistema eleitoral, faz trabalhar o sistema político como um todo.

Mesmo que na realidade os partidos sejam fruto menos da necessidade de representação dos cidadãos e mais da divergência entre indivíduos políticos - choque de vaidades e egos - e da necessidade de sobrevivência política, eles são os responsáveis por estruturar o contexto eleitoral, e fazem isso a partir da formação de alianças e da agregação dos interesses dos eleitores, o que se torna fundamental para o sucesso eleitoral. Dessa forma, os partidos estão longe de ser apenas abstrações jurídico-institucionais que possuem relevância somente no meio parlamentar, de modo que seria compreensível se, no âmbito eleitoral, eles, em face de seu caráter representativo, se organizassem a partir das divisões sociais existentes.

No Brasil, visando fins eleitorais e cientes da diversidade de votantes, as organizações partidárias tendem a deixar de lado a fidelidade ideológica, caso essa já tenha existido, para conduzir sua estratégia política por dois caminhos: mobilizar outras clivagens que extrapolem a polarização esquerda-direita, sensibilizando um eleitorado específico, ou investir na busca por um apoio mais amplo, pautado pelo eleitor mediano, o qual é mais flexível e influenciado especialmente por fatores de curto prazo (KIRCHHEIMER, 1966; LISI, 2011).

Os partidos que escolhem o primeiro caminho possuem, na literatura, a denominação de "partidos de massa" (DUVERGER, 1970; SARTORI, 1976), por organizarem e representarem uma camada social em particular, estabelecendo, com isso, raízes sociais. Já os partidos que adotam a segunda alternativa, assemelhando-se a 
máquinas eleitorais, recebem a denominação de "partidos catch-all" (KIRCHHEIMER, 1966), já que desejam captar para si o máximo de eleitores possível, independentemente do grupo social a que esses pertençam.

Atualmente, a competição eleitoral no Brasil aponta para a existência, em sua grande maioria, de partidos que se ajustam mais à segunda definição do que à primeira, o que pode ser visto nos estudos que os caracterizam na arena eleitoral por uma alta taxa de volatilidade e carência ideológica (NICOLAU, 1998; KINZO, 2005). Sem dúvida, a probabilidade de sucesso eleitoral de um partido que, por assim dizer, atira para todos os lados é maior do que as chances de vitória daquele que se centra na captação de um grupo social claramente definido ou que tem grande apelo ideológico ${ }^{3}$. O resultado disso é a estruturação de um sistema partidário composto, em geral, por organizações que se formam e caminham segundo o autointeresse de seus integrantes, que buscam, entre outras coisas, reconhecimento social, prestígio, espaço político e poder. Como consequência, o quadro eleitoral construído por essas organizações baseia-se em propostas não ideológicas de programas de governo bem como em um discurso generalista, superficial, que não costuma mobilizar nem pontuar divisões sociais que possam servir como diferenças potenciais entre os concorrentes.

Considerando o contexto brasileiro, não serviria como um argumento plausível para a não mobilização de clivagens sociais pelos partidos e candidatos o fato de essas não existirem. Raça, renda, região, gênero e religião são exemplos de temas conflituais que, no Brasil, ainda suscitam preconceitos e desigualdades e que, portanto, poderiam ser articulados por eles de forma específica para funcionar como catapultas eleitorais. No entanto, conforme já mencionado, o investimento eleitoral em um grupo particular não é uma estratégia política comum, e como exemplo de sua baixíssima eficiência eleitoral pode-se citar o caso brasileiro do Partido da Causa Operária (PCO), que mobilizando claramente a clivagem de classe e posicionando-se a favor dos trabalhadores, em seus 20 anos de fundação nunca conquistou mandato algum em nenhuma das três esferas de

\footnotetext{
${ }^{3}$ E essa é uma realidade não só do sistema político brasileiro. Lisi (2011), ao analisar a evolução ideológica e programática dos partidos portugueses, conclui que, com exceção parcial do Partido Comunista Português (PCP), a estratégia político-eleitoral antecedeu a definição ideológica. Contrariando a trajetória típica dos partidos de democracias mais antigas, os partidos portugueses primeiro decidiram para onde iriam e depois estabeleceram quem eram, visando serem reconhecidos pelos eleitores como atores legítimos dentro do sistema político. A importância da captação dos eleitores de centro, principalmente, fez o PCP, para citar um exemplo, adaptar as suas orientações programáticas em 1988, tendo como principal objetivo não mais realizar uma "revolução democrática e nacional" e sim "lutar por uma democracia avançada" (LISI, 2011, p. $52)$.
} 
governo. Tudo isso parece confirmar a ideia weberiana da irredutibilidade do político ao socioeconômico.

Nesse cenário, a disputa eleitoral é orquestrada pela elite política, sobre bases formadas por fatores de curto prazo e propostas programáticas criadas a partir de temas que são mobilizados pelos candidatos no decorrer da campanha, a depender da temática dos deslizes cometidos por quem está no governo, que certamente serão explorados pelos adversários, ou de qual seja a questão que esses últimos mais dominam para se impor no debate. Com efeito, as diferenças entre os candidatos, quando existem, baseiam-se em aspectos voláteis e não estruturais, tática utilizada para captar o maior eleitorado possível, o que faz com que os partidos acabem lutando pela mesma faixa de eleitores.

Nas eleições de 2002 para o governo paulista, por exemplo, a questão da violência e segurança pautou boa parte da campanha política dos candidatos, devido tanto a fatores ocasionais quanto à facilidade do candidato Paulo Maluf (PPB) de mobilizar em seu discurso esse tema e captar eleitores preocupados com ele. O resultado foi que os outros dois principais candidatos, Geraldo Alckmin (PSDB) e José Genoíno (PT), também se voltaram para essa questão, na tentativa de adentrar no terreno seguro de Maluf e competir com este pelos votos desse eleitorado. A campanha política de Alckmin se voltou com afinco para o interior de São Paulo, tendo em vista que, segundo pesquisas encomendadas pelo PSDB, lá estavam os eleitores mais vulneráveis ao discurso de Maluf sobre segurança.

Ainda que existam estudos de sociologia eleitoral que apontem e comprovem a heterogeneidade e a indiferenciação social das bases eleitorais das organizações partidárias (GASPAR; ANDRÉ, 1989; FREIRE, 2001; AMES, 2003; LISI, 2011), isso não significa dizer que os partidos não sejam capazes, mesmo utilizando estratégias políticas voltadas para um eleitorado amplo, de mobilizar e estruturar o voto de um tipo de eleitor em particular. A peculiaridade desse grupo de eleitores pode não estar em sua consonância com as linhas ideológicas ou programáticas do partido e sim na sua qualidade de simpatizantes, ou seja, eleitores que simplesmente apoiam ou se identificam com determinado partido e/ou com seu candidato (WHITELEY; SEYD, 2002).

Deve-se lembrar que a compreensão que os eleitores possuem do processo político-eleitoral depende da atuação dos partidos, os quais não são somente agregadores de interesse, mas também formadores de opiniões e atitudes. O voto, portanto, torna-se, 
além de um mecanismo de escolha, um instrumento de expressão em apoio àquilo que é defendido por certo partido e seu candidato.

Se a ideologia não tem hoje no Brasil grande peso na distribuição dos votos nos partidos políticos e em seus candidatos, é possível que os eleitores simpatizantes formem um grupo homogêneo em termos socioeconômicos e geográficos o suficiente para permitir que eles interfiram potencialmente nos resultados eleitorais. Mesmo que os principais partidos brasileiros sejam organizações interclassistas, competindo por bases eleitorais semelhantes e heterogêneas, deve-se considerar a possibilidade de que, dentro dessa heterogeneidade, estejam grupos de eleitores que compartilham características (idade, educação, renda, localização geográfica etc.) e que podem pesar no sucesso eleitoral de uma candidatura.

Vários estudos foram feitos nesse sentido, abarcando especificamente $\mathrm{o}$ contexto eleitoral da cidade de São Paulo, e não do estado. Acredita-se, no entanto, que as ideias e conclusões advindas desses trabalhos são de grande valia para ilustrar o que tem sido produzido até o momento nesse campo e, mais importante, para auxiliar a pesquisa produzida aqui e mostrar ao longo dos anos quais clivagens foram consideradas e colocadas em primeiro plano por diferentes autores.

Aziz Simão, em trabalho intitulado “O voto operário em São Paulo" (1956), estuda a distribuição do voto operário entre o eleitorado paulista nas eleições de 1947 para as assembleias estaduais. A partir da divisão da cidade em quatro zonas eleitorais majoritariamente operárias ${ }^{4}$, o autor observou que o Partido Comunista do Brasil (PCB) e o Partido Trabalhista Brasileiro (PTB) foram os partidos principais entre os quais se dividiram os votos dessas regiões. Segundo Simão, o eleitorado do PCB incluía pessoas nascidas na capital, as quais residiam, em grande parte, nos antigos bairros industriais, destacando-se os homens entre 18 e 40 anos, trabalhadores em serviços especializados. Já o PTB tinha como eleitores pessoas advindas das zonas rurais nos anos 40, as quais estavam empregadas menos em fábricas e mais em serviços que exigiam pouca ou

\footnotetext{
${ }^{4}$ A primeira zona, que margeava o que Simão denominou de Y ferroviário, reunia o maior eleitorado operário da cidade de São Paulo, com 68\%, e compreendia 19 distritos; entre eles estavam Ipiranga, Mooca, Brás, Tatuapé, Penha, Bom Retiro, Barra Funda e Lapa. A segunda zona, por ser mais afastada do eixo ferroviário e possuir ocupação recente, abrangia $7 \%$ do total de eleitores operários da capital, os quais estavam divididos nos distritos de Santo Amaro, Indianópolis, Ibirapuera e Saúde. A terceira zona, classificada pelo autor de "suburbana", concentrava somente 4\% dos eleitores operários, divididos entre Itaquera, Baquirivu, Guaianases, Pirituba, Perus e Osasco. Por fim, a quarta zona incluía três distritos (Butantã, Capela do Socorro e Parelheiros), que abarcavam 1,21\% do total do eleitorado operário.
} 
nenhuma qualificação profissional nas áreas de pequenos ofícios, construção civil e transportes. Segundo o autor, o eleitorado petebista, principalmente aquele originário do êxodo rural, via a legislação trabalhista de Getúlio Vargas com bons olhos e retribuía isso votando em seu partido. Nesse sentido, para Simão, a clivagem urbano-rural era fundamental para entender as bases de apoio dos partidos.

O trabalho de Oliveiros Ferreira, intitulado "Comportamento Eleitoral em São Paulo" (1960), que foca igualmente a divisão rural versus urbano, como fez Simão, analisou, além das eleições para senador e deputado estadual e federal em 1958, as eleições para o governo do estado nesse ano e em 1954, considerando, para isso, também a estrutura socioeconômica. A clivagem urbano-rural foi trabalhada pelo autor a partir do índice de industrialização do município, o que permitiu o agrupamento desses em três zonas diferentes. No pleito de 1954, Jânio Quadros, que concorreu pelo pequeno Partido Trabalhista Nacional (PTN), venceu Adhemar de Barros, do Partido Social Progressista (PSP), que era o candidato do governo apoiado tanto pelo PTB quanto pelo agora ilegal PCB. Segundo Ferreira, Jânio, com um discurso pautado pela impessoalidade e eficiência administrativa, obteve mais votos na zona com maior índice de industrialização, enquanto o seu adversário, enfatizando a tradição e a manutenção do status quo, perdia votos à medida que a região se tornava mais industrializada/urbanizada.

Em 1958, Barros perdeu novamente, mesmo contando com a estrutura montada pelos partidos aliados tanto na capital quanto no interior do estado - desta feita, para Carvalho Pinto, do Partido Democrata Cristão (PDC), que, sendo apoiado por Jânio, apropriou-se de seu discurso da campanha anterior. Para Ferreira, o padrão de votação nas três áreas era claro: o voto na oposição ocorria nas regiões mais industrializadas e o contrário acontecia com relação ao voto no governo. Segundo Francisco Weffort, seria plausível a hipótese “(...) segundo a qual Jânio Quadros tenderia a expressar politicamente os setores assalariados - operários e classe média assalariada - mais integrados no desenvolvimento capitalista, diversamente de Adhemar de Barros, que daria expressão a camadas marginais a este processo, em particular pequenos proprietários e setores assalariados de tipo lúmpen ${ }^{5 "}$ (WEFFORT, 1965, p. 56).

No tocante ao período da ditadura militar, Bolívar Lamounier, no artigo “Comportamento Eleitoral em São Paulo: passado e presente” (1975), vinculou voto e

\footnotetext{
${ }^{5}$ Lúmpen é um termo utilizado para designar assalariados de remuneração extremamente baixa. Segundo Bolívar Lamounier (1980), as pessoas de baixíssima renda votariam tanto na ARENA quanto no MDB.
} 
posição socioeconômica no estudo que fez das eleições legislativas na cidade de SP, mais especificamente, da votação de Orestes Quércia, candidato ao Senado pelo Movimento Democrático Brasileiro (MDB). Lamounier, utilizando método semelhante aos utilizados pelos autores já citados, dividiu o mapa da capital em quatro áreas diferentes, de acordo com a votação de Quércia, o que indicou que os votos ao MDB aumentavam quanto maior e mais periférica fosse a área. Os dados organizados pelo autor mostravam ainda que o MDB era a escolha principal (80\%) entre os eleitores que eram empregados domésticos, ambulantes ou que trabalhavam ocasionalmente. Essa porcentagem caía para $60 \%$ entre operários qualificados e trabalhadores manuais com baixos salários e para $48 \%$ entre empregadores - administradores, proprietários e gerentes. Dessa forma, o MDB, partido de oposição ao governo, estaria associado aos mais pobres, enquanto a ARENA se relacionaria com os mais ricos. Segundo o autor, a vinculação entre diferenciações socioeconômicas e voto “(...) desqualifica a hipótese de um comportamento caótico ou puramente clientelista" (LAMOUNIER, 1975, p. 22). Em outro trabalho intitulado "O voto em São Paulo, 1970-1978”, Lamounier, valendo-se da divisão social pautada pela idade, apontou que os mais jovens tenderiam a votar no MDB, enquanto os mais velhos se inclinariam a votar na ARENA.

Após a ditadura, período no qual os governadores e prefeitos eram indicados aos cargos, Jânio Quadros foi eleito prefeito de São Paulo (1/1986 a 12/1988); posteriormente, vieram Luiza Erundina, do Partido dos Trabalhadores (1/1989 a 12/1992), e Paulo Maluf, do então Partido Democrático Social (1/1993 a 12/1996). Antônio Flávio Pierucci, em "São Paulo 92, a vitória da direita" (1993), mostra a emergência na capital da polarização entre a esquerda petista e a direita malufista. Descreve essa polarização a partir de regiões socioeconômicas da cidade e aponta que o PT se fortaleceu na capital graças aos votos de bairros periféricos e carentes, mobilizando o eleitorado mais pobre da periferia paulistana bem como alguns eleitores progressistas das classes médias e médias altas. Já Maluf começou a ganhar votos entre os distritos da classe média baixa e entre os eleitores de classe alta.

Segundo Limongi e Mesquita (2008), as oscilações na votação para a prefeitura de São Paulo entre esquerda e direita são explicadas pelo fato de que, devido ao alto grau de polarização ideológica, as vitórias de um ou outro lado seriam decididas pelos eleitores de centro, os quais votariam de acordo com fatores de curto prazo. Ao analisarem as 
eleições para a prefeitura da capital de 1985 até 2004, ano da vitória de José Serra (PSDB), objetivando "(...) caracterizar o apoio aos diferentes partidos ao longo do tempo" (LIMONGI; MESQUITA, 2008, p. 51), os autores apontam que o PT, a partir da vitória de Maluf nas eleições de 1992, começa a ser visto como um partido de oposição apoiado, na capital, principalmente pelos eleitores de baixa renda e baixo grau de escolaridade. Conforme aponta Rocha (2012, p. 277), “(...) São Paulo [a cidade] acolheu o PT, entre idas e vindas, como o principal partido de esquerda oposicionista, que mobiliza, atualmente, sobretudo as camadas trabalhadoras mais empobrecidas".

Segundo dados de entrevistas realizadas em 2014 pela jornalista Julia Duailibi ${ }^{6}$ com pessoas ligadas à campanha tucana em SP, nas eleições desse ano o governador e candidato à reeleição, Geraldo Alckmin, juntamente com sua equipe de assessores, munidos de resultados advindos de pesquisa qualitativa, estratificaram o eleitorado paulista em cinco tipos: "hard pró", "soft pró", "hard contra", "soft contra" e "indeciso".

Os eleitores "hard pró", que representavam 19\% do eleitorado, eram os totalmente a favor de Alckmin e avaliavam seu governo como bom ou ótimo, dando-lhe nota entre sete e dez. Esse estrato correspondia aos eleitores interioranos com mais de 45 anos, que ganhavam até dois salários mínimos. Citando um dos entrevistados, "o eleitor do Alckmin é baixa renda, é o eleitor que era do PT”.

Os "soft pró” são os eleitores que “(...) a favor, mas não pulam do viaduto com ele [Alckmin]". Esse estrato representava 34\% do eleitorado que normalmente se mantém entre as eleições, o qual não precisa de muitos argumentos para dar o voto. Encaixam-se nesse tipo de eleitor homens com ensino fundamental e renda entre dois e dez salários mínimos, que moram na periferia, sobretudo no interior e em municípios de 50 a 200 mil habitantes.

Os eleitores qualificados como "hard contra" eram os que rejeitavam Alckmin e avaliavam o governo como ruim ou péssimo, atribuindo-lhe nota de zero a três. Entre

\footnotetext{
${ }^{6}$ Julia Duailibi é jornalista especializada em reportagem política e já trabalhou na Folha de S. Paulo, no Estadão e atualmente está na Revista Piauí. No número 99 da Revista Piauí, lançado em dezembro de 2014, Duailibi foi a autora de um artigo sobre o perfil de Geraldo Alckmin, intitulado "O paulista Ge-ral-do: quem é o político católico e caipira que assume pela quarta vez o governo de São Paulo". A jornalista acompanhou a campanha política de Alckmin no estado e fez entrevistas com várias pessoas ligadas à história do candidato, como o marqueteiro Nelson Biondi, Mário Covas Neto, Paulo Maluf e Fernando Henrique Cardoso. Sabendo do amplo conhecimento que Duailibi tinha adquirido no tempo em que ficou perto do governador, entrei em contato com ela, sendo-me então disponibilizados alguns dados que havia coletado. As informações do seu material que estão nesse artigo não mencionam os nomes dos entrevistados, a pedido da jornalista.
} 
eles estavam os que possuíam ensino superior e renda maior que dez salários mínimos, que moram na capital do estado e em cidades acima de 200 mil habitantes.

Já os eleitores "soft contra", que eram 15\%, não rejeitavam Alckmin, mas também não votavam nele. Nessa classificação se encaixava o cidadão com ensino superior e renda entre dois a cinco salários mínimos.

Por fim, havia $22 \%$ de eleitores indecisos, principalmente mulheres com ensino superior, que não avaliavam o governador nem como ruim, nem como péssimo.

Percebe-se, a partir do que foi exposto, que clivagens como idade, gênero, renda e local de moradia mostram-se importantes para a definição da estratégia de captura de votos no contexto eleitoral paulistano e paulista. É interessante notar que em 2014, por exemplo, o conhecimento do perfil social e econômico do eleitorado não foi utilizado visando à escolha e à manutenção de um grupo de eleitores em particular; ao contrário, pretendeu-se identificar onde estava o ponto mais fraco, isto é, os eleitores que não apoiavam e não votariam em Alckmin, a fim de estabelecer estratégias que os trouxessem para o lado desejado.

As pesquisas qualitativas contratadas por partidos, candidatos e governos sobretudo no período próximo às eleições são fundamentais na montagem das estratégias políticas para as campanhas. Diferentemente das pesquisas quantitativas, que medem as intenções de votos e ajudam partidos e candidatos a mensurar sua popularidade ante os eleitores, as pesquisas qualitativas os auxiliam na definição da melhor tática para conquistar votos. Para isso é preciso saber quem são, onde estão e quais as demandas dos potenciais eleitores, bem como dos não eleitores. Em outras palavras, a maioria dos atores políticos de uma competição eleitoral não se organiza a partir de clivagens sociais, mas as levam em consideração para a delimitação de métodos de abordagem do eleitorado. É dessa maneira que as políticas propostas pelos candidatos se tornam generalistas e desfocadas, tornando-os praticamente iguais perante os eleitores.

É fato que os eleitores simpatizantes, ao contrário do que poderia supor um marxismo economicista mais inflexível, nem sempre constituem um eleitorado estável, de modo que fatores circunstanciais como crise política, escândalos de corrupção, mau andamento da economia, alta taxa de desemprego ou até uma simples troca de candidato, são capazes de mudar o seu comportamento e de modificar sua decisão. Não obstante a importância do contexto e das circunstâncias para o resultado eleitoral, as bases eleitorais 
dos candidatos apontam para clivagens e divisões que podem ser mobilizadas e articuladas por partidos e atores políticos como linhas de conflito, indicando a capacidade deles de restringir a competição política em torno de uma questão, tema ou proposta política.

Idade, educação, gênero, renda, local de moradia e as dimensões religiosa e socioprofissional são atualmente as principais clivagens sociais, as quais tendem a permanecer as mesmas entre as diversas disputas eleitorais (LIMONGI; MESQUITA, 2011), sabendo da habilidade dos partidos em condicionar as opções dos eleitores apesar das mudanças sociais latentes (MAIR, 1997).

\subsection{Hipóteses para explicação do sucesso de Alckmin em São Paulo: voto e status socioeconômico}

No caso das eleições de Geraldo Alckmin para o governo de São Paulo, considerando a possível relevância dos índices sociais e econômicos nos resultados eleitorais, a primeira hipótese é a de que variáveis socioeconômicas relativas aos municípios paulistas interferem na votação de Alckmin na localidade, aumentando-a ou diminuindo-a. Mais especificamente, desejou-se verificar se o aumento da idade, da renda e da educação favorece uma distribuição positiva do voto em Alckmin no município, contribuindo para o seu êxito eleitoral no estado. Esse pressuposto baseia-se principalmente em achados de autores que se debruçaram em seus estudos sobre a relação entre os partidos políticos e suas bases eleitorais e o perfil dessas.

Marco Lisi (2011), em seu trabalho sobre os partidos políticos em Portugal, salienta que o peso dos votantes mais idosos - aqueles com mais de 55 anos - nas organizações partidárias passou nos últimos anos de aproximadamente 1/3 do eleitorado para cerca de $40 \%$, especialmente quando se trata dos partidos que ocupam o governo e daqueles localizados à direita do espectro ideológico. $\mathrm{O}$ autor considera que esse processo está intimamente relacionado ao gradual envelhecimento da sociedade e com o relativo afastamento da camada mais jovem da população da arena política, o que culmina na dificuldade dos partidos em estruturar seus votos (LISI, 2011). Ao analisar a evolução

etária das bases dos partidos portugueses, o autor aponta que "o declínio mais evidente dos grupos etários mais novos registra-se no PSD [Partido Social Democrata], em que a 
percentagem dos eleitores com menos de 34 anos passou de quase 34\% em 1984 para cerca de 25\% em 2005" (LISI, 2011, p. 106).

$\mathrm{O}$ autor demonstra ainda que os eleitores dos partidos de centro-direita tendem a possuir grau de educação mais elevado que os dos partidos de esquerda. Em Portugal, o PSD e o Partido do Centro Democrático Social (CDS), ambos considerados de centrodireita, possuem as maiores proporções de eleitores com nível educacional elevado (LISI, 2011). Cerca de $30 \%$ dos eleitores do CDS têm um curso (ou frequência) de licenciatura, de modo que "esta percentagem é, no caso dos partidos de esquerda, equivalente a cerca de um quinto dos respectivos eleitorados" (LISI, 2011, p. 107). No que se refere ao Partido da Social Democracia Brasileira (PSDB), considerado por muitos autores um partido de centro $^{7}$, a sua aliança, no caso do Poder Executivo paulista, com partidos localizados à direita do espectro ideológico, em especial com o antigo PFL - hoje Democratas -, a qual se mostra importante para a vitória tucana, como se verá posteriormente, motivou a construção dessa hipótese nessa direção.

Supõe-se também que quanto menor for a desigualdade de renda entre a população e maior for a taxa de empregos formais no município, a votação em Alckmin terá distribuição positiva. Conforme dito nas páginas anteriores, aspectos relativos ao contexto político e ao dia a dia dos eleitores são passíveis de influenciar o seu comportamento quanto à tomada de decisão do voto. $\mathrm{O}$ contentamento da população com a sua qualidade de vida, o que inclui desde boas condições de infraestrutura - transporte público, iluminação, estradas - até o melhoramento da educação, saúde e segurança, bem como o aumento das vagas de emprego, certamente possui um peso significativo na vitória de quem ocupa o governo.

Para citar um caso, basta lembrar que a reeleição de Mário Covas, que tinha Alckmin como candidato a vice, quase foi prejudicada por altas taxas de desemprego e criminalidade, que foram consequências de medidas de austeridade implantadas no primeiro mandato, a fim de controlar um desequilíbrio fiscal iniciado no governo antecessor, o que resultou no bloqueio dos gastos públicos. Esse é um exemplo de como

\footnotetext{
${ }^{7}$ Oficialmente, o PSDB se autodenomina um partido de centro-esquerda, o que pode ser percebido pelo que está colocado no artigo segundo do seu estatuto: "O PSDB tem como base a democracia interna e a disciplina e, como objetivos programáticos (...) a construção de uma ordem social justa e garantida pela igualdade de oportunidades (...) e a realização do desenvolvimento de forma harmoniosa, com a prevalência do trabalho sobre o capital, buscando a distribuição equilibrada da riqueza nacional entre todas as regiões e classes sociais". Ver estatuto completo em http://static.psdb.org.br/wpcontent/uploads/2016/02/Estatuto\%202015 12 final.pdf.
} 
problemas que são não apenas mostrados numericamente, mas sentidos no dia a dia dos cidadãos, podem afetar negativamente as pretensões eleitorais de atores políticos que se encontram no governo.

As políticas, sejam aquelas criadas pelo governo, sejam pela oposição, também podem influir no comportamento do eleitor e beneficiar uma ou outra parte, a depender de quem o eleitorado entende ser o seu criador. O Bolsa Família, instituído em 2003 pelo governo federal petista, é um programa de transferência de renda comumente associado ao Partido dos Trabalhadores e, por essa razão, considerado um instrumento de ganho de votos para seus integrantes. Estudos comprovam que a cobertura do programa Bolsa Família (PBF), isto é, a proporção de famílias que são beneficiadas no município, associase positivamente, por exemplo, com a votação obtida por Lula nas eleições de 2006 (LIMONGI; GUARNIERI, 2015; ZUCCO, 2008).

Limongi e Guarnieri (2015), embora ressaltem que essa relação positiva não comprova que o Bolsa Família seja o fator determinante para explicar o comportamento do eleitor em benefício do PT, concluíram que em 2006 a relação entre a cobertura da política e o voto em Alckmin, concorrente nesse ano à presidência pelo PSDB, era inversa à que ocorria com Lula: o petista ganhava, comparado ao tucano, mais votos nas regiões com maior número de famílias atendidas pelo programa. Com efeito, é visando medir a influência do alcance do Bolsa Família na votação atribuída à Alckmin e ao PSDB na competição pelo governo paulista que o número de famílias beneficiadas em cada município foi incluído como variável nesse estudo. A hipótese é de que ocorra no pleito estadual aquilo que Limongi e Guarnieri encontraram nas eleições federais: a votação em Alckmin é menor nos municípios com mais famílias atendidas pelo PBF.

De outro lado, o projeto obreiro de governantes, que se resume na feitura ou na inauguração de obras realizadas às vésperas de uma eleição, pode ter consequências tanto para o bem, possuindo alta capilaridade eleitoral, quanto para o mal. Nas eleições de 2014, Alckmin não venceu em apenas um dos 645 municípios do estado: Hortolândia, que dista cerca de 110 quilômetros da capital. Muitas causas foram atribuídas à derrota tucana nesse município, e entre elas estava o fato de que na gestão do PSDB na prefeitura houve a construção do complexo penitenciário Professor Ataliba Nogueira, apelidado de "Carandiru Caipira", por ter recebido a maior parte dos presos da antiga Casa de Detenção de São Paulo, quando da sua desativação em 2002. Embora esse caso fizesse parte do 
passado, a população hortolandense o considerou parte de um passado recente, que parece ter ficado ainda mais vivo quando o governador do estado anunciou em 2005 a instalação da Fundação Casa - antiga Fundação Estadual do Bem- Estar do Menor (FEBEM) - no município, o que acarretou uma série de protestos e manifestações, obrigando Alckmin a voltar atrás na decisão. Nessa época, a gestão de Hortolândia já tinha passado para as mãos do PT e o sucesso do prefeito petista, reforçado pelos deslizes cometidos pelos tucanos, também foi avaliado como uma das causas para a única derrota de Alckmin em $2014^{8}$.

Dado o papel-chave do prefeito nas eleições estaduais, já que ele funciona como cabo eleitoral de candidatos a deputado, governador e até mesmo presidente, também foi incluída na análise das vitórias de Geraldo Alckmin a variável política referente ao prefeito do município. Verificou-se se a votação dada a Alckmin foi afetada em alguma medida pelo fato de o prefeito ser de partido aliado ao governo ou pertencente à oposição. Teoricamente, diante da personificação do partido no prefeito, o mais provável seria que a votação diminuísse nos municípios que contam com prefeitos que compõem partidos da oposição.

Seja por fatores socioeconômicos ou por conta de variáveis políticas como a colaboração do prefeito ou a construção de obras visíveis aos olhos da população, é possível que um candidato consiga dispor de bases eleitorais com as quais pode contar para a vitória. A literatura sobre geografia eleitoral, área acadêmica recente que ainda está em expansão no Brasil e mundialmente, aponta para a existência de bases eleitorais instaladas geograficamente seja em um estado, município ou bairro, que funcionam como redutos de votos para determinado candidato.

Os vínculos estabelecidos entre essas localidades e seus escolhidos políticos são vários e podem ir desde um elo representativo formal até ligações clientelistas bilaterais, baseadas na política do toma lá, dá cá. O tipo de relação construída entre esses eleitores e políticos definirá de que forma os últimos irão manter tais votos, o que é o mais importante para a batalha travada na competição eleitoral.

Sobretudo nas duas últimas eleições (2010 e 2014), o sucesso eleitoral de Alckmin foi associado à sua força política entre os eleitores que vivem nos municípios do interior do estado. Se consultadas algumas das pesquisas de opinião feitas por diversos

\footnotetext{
${ }^{8}$ Essas informações foram retiradas da matéria intitulada "Em Hortolândia, o PSDB não tem vez" escrita pela jornalista Marsílea Gombata e publicada on-line na revista Carta Capital em 14/10/2014. Ver em http://www.cartacapital.com.br/politica/em-hortolandia-o-psdd-nao-tem-vez-7597.html.
} 
institutos antes das três eleições do tucano, ver-se-á que o panorama de apoio eleitoral pode realmente ter mudado um pouco entre 2002 e 2010. Em 2002, pesquisa do Ibope divulgada pouco antes do segundo turno das eleições mostrava que Alckmin, apesar de estar na frente de seu adversário, José Genoíno, do PT, tinha maior rejeição no interior de SP $(29 \%)^{9}$. Nessa eleição, o tucano acabou vencendo em todas as macrorregiões do estado.

Já em 2010, de acordo com pesquisa do Datafolha divulgada em agosto ${ }^{10}$, Alckmin aparecia com 58\% das intenções de voto entre os eleitores interioranos, 43 pontos à frente do petista Aloizio Mercadante. Alckmin se saiu vitorioso em 2010 já no primeiro turno. Faltando pouco mais de um ano para as eleições de 2014, pesquisa do Datafolha divulgada em julho ${ }^{11}$, em meio às manifestações de 2013, mostrava Alckmin com 46\% das intenções de voto no interior, contra 19\% do segundo colocado, Paulo Skaf (PMDB). Nessa eleição, o desempenho eleitoral do tucano foi surpreendente: não venceu em apenas um município no primeiro turno.

\subsection{Metodologia}

Primeiramente, antes de avaliar a relevância do peso eleitoral que possuem os fatores socioeconômicos na votação de Geraldo Alckmin, replicando e tornando mais robusta a análise feita por outros autores, entendeu-se ser de extrema importância descrever o arranjo das proporções de votos recebidas pelo tucano no estado em suas três eleições. Buscou-se, a partir de um estudo geográfico, observar algum padrão espacial de regiões onde ocorra grande ou baixa votação. Além disso, sabendo que análises geográficas pressupõem autocorrelação espacial, calculou-se o Índice de Moran I visando identificar o grau de autocorrelação espacial da proporção de votos recebida por Alckmin em suas vitórias.

O índice I de Moran (I), também chamado de Moran Global, indica a correlação espacial univariada de uma ou mais variáveis espaciais. No caso, a variável espacial é a proporção de votos recebida por Alckmin em SP. Sendo o índice calculado a partir dos centroides de cada município, foram extraídos a partir do site do IBGE os dados

\footnotetext{
${ }^{9}$ Ver http://www4.ibope.com.br/opp/pesquisa/politica/eleicoes/download/eleicoes_2002_sp_opp514_01.pdf. 10 Ver http://datafolha.folha.uol.com.br/eleicoes/2010/08/1131267-geraldo-alckmin-psdb-mantem-alideranca.shtml.

11 Ver http://www1.folha.uol.com.br/poder/2013/07/1304683-interior-salva-alckmin-de-recuo-maior-empesquisa.shtml.
} 
de latitude e longitude de cada um deles para o cálculo de uma matriz de distância, necessária para estimar a variabilidade espacial dos dados (SOARES; TERRON, 2008). A partir das distâncias e do valor de cada variável para os pontos, calculou-se a autocorrelação espacial global da proporção de votos, verificando-se se pontos próximos tinham valores parecidos na média.

$\mathrm{O}$ índice varia de -1 a 1 . Valores próximos a -1 indicam autocorrelação espacial negativa (pontos dispersos). Valores próximos a 1 indicam autocorrelação espacial positiva (pontos agrupados). Já valores próximos a zero apontam para ausência de autocorrelação espacial, ou seja, padrão espacial aleatório. Nesse sentido, o objetivo do índice de Moran I foi indicar um padrão que possa caracterizar territórios eleitorais (bases eleitorais). Dessa forma, foram calculados quatro índices $(I)$, um para cada ano eleitoral, incluindo ainda o referente ao segundo turno em 2002.

Feito isso, as variáveis mostradas na tabela 1 foram selecionadas por município paulista - ao todo 645 -, a fim de compor a investigação sobre o êxito eleitoral de Geraldo Alckmin nas eleições de 2002, 2010 e 2014 em relação a variáveis socioeconômicas, ressaltando que os dados eleitorais de 2002 correspondem ao segundo turno. Para cada ano foi construído um modelo logístico linear generalizado (generalized linear model - GLM), obedecendo-se às premissas de linearidade, aleatoriedade e normalidade. Os dados eleitorais foram adquiridos no site do Tribunal Superior Eleitoral (TSE) e os indicadores socioeconômicos tiveram como fonte as informações do Instituto Brasileiro de Geografia e Estatística (IBGE) bem como da Fundação Sistema Estadual de Análise de Dados (SEADE). Assumiu-se que a proporção de votos em Geraldo Alckmin decorre de uma combinação de fatores socioeconômicos e variáveis políticas, os quais, destacados por ano eleitoral, correspondem às variáveis independentes descritas abaixo ${ }^{12}$ :

Tabela 1 - Variáveis independentes utilizadas nos modelos, relacionadas por ano eleitoral

\begin{tabular}{c|c}
\hline $\begin{array}{c}\text { Ano } \\
\text { eleitoral }\end{array}$ & Variáveis Independentes \\
\hline 2002 & $\begin{array}{c}\text { Anos de estudo (2000), IDHM* - dimensão renda (2000), índice de envelhecimento, índice de } \\
\text { Gini (2000), partido do prefeito e número de empregos formais. }\end{array}$ \\
\hline 2010 & $\begin{array}{c}\text { Anos de estudo, IDHM - dimensão renda, índice de envelhecimento, índice de Gini, partido do } \\
\text { prefeito, número de empregos formais e número de famílias que recebem o Programa Bolsa } \\
\text { Família. }\end{array}$ \\
\hline
\end{tabular}

\footnotetext{
${ }^{12}$ As estatísticas descritivas das variáveis utilizadas nos modelos estão dispostas no apêndice (tabela A.1), ao final da dissertação.
} 
IPRS** - dimensão escolaridade (2012), IPRS - dimensão riqueza (2012), índice de envelhecimento, índice de Gini (2010), partido do prefeito, número de empregos formais e número de famílias que recebem o Programa Bolsa Família.

\footnotetext{
*Índice de Desenvolvimento Humano Municipal.

**Índice Paulista de Responsabilidade Social: é um indicador que, semelhante ao IDH, tem a finalidade de medir a qualidade de vida da população paulista, incluindo as dimensões de escolaridade, rendimento e longevidade. Foi elaborado pela Fundação Sistema Estadual de Análise de Dados (SEADE).

Fonte: elaboração da autora.
}

Antes, porém, de seguir com o resultado das análises, algumas considerações metodológicas precisam ser explicitadas. Tendo em vista a dificuldade de se encontrar, em alguns casos, indicadores que correspondessem exatamente ao ano em que houve as eleições, foram feitas aproximações, utilizando-se dados disponibilizados de anos próximos. As variáveis que não correspondem ao ano eleitoral em questão têm o seu ano equivalente mostrado entre parênteses na tabela 1. Além disso, algumas variáveis relativas aos anos de 2002 e 2010 não foram encontradas disponíveis para o ano de 2014; por isso, a fim de se aferir educação e renda, foram escolhidos outros indicadores: o Índice Paulista de Responsabilidade Social (IPRS) - dimensão escolaridade e o IPRS-dimensão riqueza, ambos referentes ao ano de 2012.

Vale ressaltar ainda que devido à indisponibilidade do índice de Gini para o ano de 2014, este índice relativo ao ano de 2010 foi incluído na análise da última eleição, a fim de se ter essa medida como forma de controle em todos os anos eleitorais. Por último, cabe pontuar que tanto o número de famílias que são beneficiadas pelo programa Bolsa Família quanto o número de empregos formais, por representarem variáveis com valores absolutos por município, foram transformados em porcentagem, utilizando-se, para tanto, a população municipal no ano respectivo. Após isso, a variável proporção de empregos formais foi transformada para logaritmo neperiano, para que fosse mantida a premissa de linearidade.

A fim de visualizar geograficamente a votação de Alckmin no estado em relação a aspectos sociais e econômicos dos municípios paulistas, foram elaborados mapas nos quais foram plotadas as proporções de votos por município, bem como as variáveis independentes que se mostraram significativas de acordo com os modelos estatísticos. As classes das variáveis para as legendas foram criadas a partir da identificação do máximo e do mínimo observado em cada variável. A partir disso se separou cada variável em seis grupos com o mesmo número de observações. Os máximos e os mínimos de cada grupo resultaram nos valores das classes nas legendas. 


\subsection{Resultados das autocorrelações espaciais}

Sabendo que o valor de $p$ indica a significância associada ao índice, o cálculo do Moran I para as eleições de Geraldo Alckmin resultou nos seguintes valores mostrados na tabela 2, abaixo:

Tabela 2 - Valores do índice de Moran I (I) para as proporções de voto em

\begin{tabular}{|c|c|c|c|c|}
\hline & $\begin{array}{c}2002-10 \\
\text { turno }\end{array}$ & $\begin{array}{c}2002-20 \\
\text { turno }\end{array}$ & $\begin{array}{c}2010-10 \\
\text { turno }\end{array}$ & $\begin{array}{c}2014-19 \\
\text { turno }\end{array}$ \\
\hline Alckmin & 0,$077 ; p=0$ & 0,$065 ; p=0$ & 0,$069 ; p=0$ & 0,$095 ; p=0$ \\
\hline
\end{tabular}

De acordo com o índice I de Moran, que se mostra próximo de zero em todos os casos, em nenhuma das três eleições em que Alckmin se saiu vitorioso houve um padrão de autocorrelação da proporção de votos. Esse resultado indica uma boa distribuição dos votos de Alckmin por São Paulo, o que sinaliza para uma estadualização do apoio eleitoral dado ao tucano. Na verdade, o sucesso de Alckmin parece estar relacionado não a bases eleitorais concentradas em determinadas regiões, mas, ao contrário, à desconcentração da votação, que se espalha por todo o estado.

Em trabalho intitulado "Geografia eleitoral e manutenção do poder: a importância das bases eleitorais para a reeleição do executivo estadual" (2014), analisei as reeleições do candidato, do partido e da coligação em uma amostra de estados brasileiros e mostrei que a dispersão da votação está associada à reeleição do candidato, diversamente do que ocorre quando o partido consegue se reeleger com uma candidatura diferente. Com efeito, apontei que “(...) na reeleição do partido há certa municipalização dos votos favoráveis, de forma que o aumento da proporção de votos ocorre em municípios concentrados em regiões específicas do estado" (MAIA, 2014, p. 435). Nesse sentido, infere-se que a figura do candidato é importante para que o partido consiga a reeleição.

Tiago Prata Storni, na sua dissertação de mestrado intitulada "Comportamento Eleitoral e Estratégia Partidária: uma análise espaço-temporal das eleições de SP e MG a partir dos conceitos de Inovação e Representações Sociais" (2010), analisa geograficamente os resultados das eleições para o governo de São Paulo entre 1994 e 2006, as quais abarcam duas gestões de Mário Covas (1994 e 1998), uma de Geraldo Alckmin 
(2002) e uma de José Serra (2006). Utilizando uma metodologia de análise espacial pautada pelo Indicador Local de Autocorrelação Espacial (Local Indicator of Spatial Correlation - LISA) ou Moran Local, seus achados corroboram a ideia apresentada aqui de que a estadualização dos votos do PSDB em SP não é uma peculiaridade do tucano Geraldo Alckmin.

Storni observa a presença de clusters no estado a partir da votação recebida por Covas em 1994. O autor destaca a alta votação do tucano nas regiões de Ribeirão Preto, Taubaté e na capital, apontando que “(...) Covas conseguiu nessas eleições aliar forças metropolitanas e áreas interioranas" (STORNI, 2010, p. 87). Em 1998, identifica-se uma votação em Covas mais distribuída que a da eleição anterior. Nessa eleição, o tucano perdeu os clusters de Taubaté e Ribeirão Preto, bem como teve sua votação diminuída nos municípios com população significativa, o que, segundo o autor, “(...) fragilizou a posição de Covas em relação às eleições de 94" (STORNI, 2010, p. 93). Tentando se reeleger, Covas realmente passou por dificuldades perante o eleitorado, o que the causou certa instabilidade política, fato que será tratado posteriormente. Não obstante, Covas venceu o adversário Paulo Maluf no segundo turno.

Uma maior distribuição da votação no PSDB também foi observada pelo autor na eleição de Alckmin em 2002, destacando-se a favor do tucano as regiões do Vale do Paraíba, incluindo Pindamonhangaba, sua cidade natal, e Guaratinguetá. Já em 2010, Alckmin não manteve nos municípios a votação obtida por José Serra em 2006; isso indica que "as bases eleitorais não foram sustentadas de uma eleição para outra" (MAIA, 2014, p. 428), conforme pode ser observado no mapa abaixo, referente à diferença da votação para o governo estadual em São Paulo entre 2006 e 2010 ${ }^{13}$. Ainda assim, Alckmin em 2010 contou com uma votação bem distribuída pelo estado.

\footnotetext{
${ }^{13} \mathrm{O}$ mapa foi retirado do meu trabalho intitulado "Geografia eleitoral e manutenção do poder: a importância das bases eleitorais para a reeleição do executivo estadual", publicado na Paraná Eleitoral (a referência completa está na bibliografia). Os três intervalos que constam na legenda do mapa foram obtidos por meio de quartis advindos dos valores obtidos pela fórmula Dif(votmun) $=\% \operatorname{Vot}($ eleição $t)-\% \operatorname{Vot}($ eleição t-4). Para mais detalhes, ver trabalho.
} 


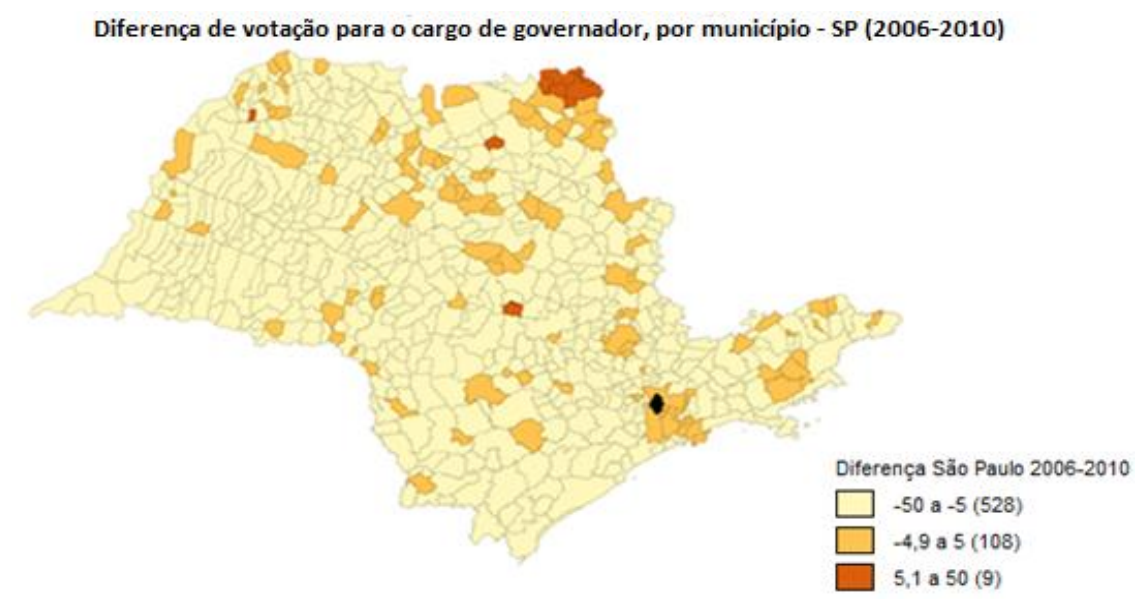

Storni conclui que os candidatos que representavam o partido governista manifestaram “(...) bases eleitorais menos visíveis espacialmente, sendo mais dispersas e inconsistentes" (STORNI, 2010, p. 108), fato que o autor destacou como importante para as vitórias tucanas, especialmente no primeiro turno. Segundo Storni, "a falta de concentração das bases eleitorais desse partido sugere que a maior parte do eleitorado não é alinhada diretamente a partidos políticos, mas que podem ser mais suscetíveis a tendências inerciais [fenômenos de campanha e visibilidade dos partidos e candidatos mais conhecidos], sendo pouco atingidos por ideias de mudança" (STORNI, 2010, p. 108/109).

Os mapas das três votações de Alckmin corroboram a distribuição da proporção de votos pelo estado, demonstrada pelo índice de Moran I. No entanto, é possível observar visualmente a diferença geográfica da votação recebida pelo tucano nos anos em que foi vitorioso, podendo-se identificar regiões de maior e menor votação nas três eleições, as quais nem sempre se repetem. No mapa relativo à votação de Alckmin em 2002 (mapa 1), observam-se regiões de destaque eleitoral - pintadas em vermelho - no leste do estado, incluindo alguns municípios que fazem fronteira com Minas Gerais e compõem o Vale do Paraíba, como Campos do Jordão, Tremembé, Pindamonhangaba e Caçapava, bem como alguns que fazem parte da macrorregião de Campinas, como Bragança Paulista, Vargem, Atibaia e Águas de Lindoia. Na região que abarca a capital e a Baixada Santista, constata-se uma votação menor que a verificada nos municípios das localidades citadas, assim como é o caso de parte significativa da macrorregião de Sorocaba, ao sul do estado. De modo geral, no interior verifica-se uma votação em Alckmin bastante distribuída e heterogênea. 


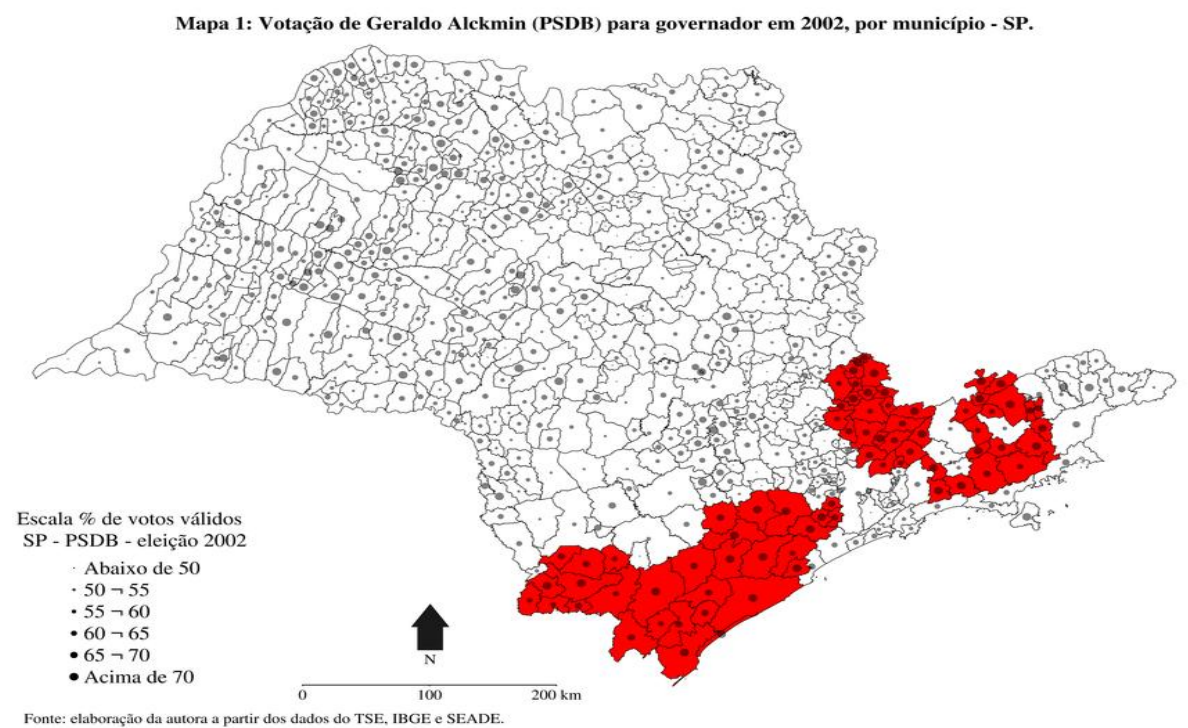

Nas eleições de 2010 (mapa 2), a votação recebida por Alckmin no segundo turno foi, assim como em 2002, bem distribuída pelo estado, tendo em vista que ele recebeu em vários municípios de todas as 15 regiões administrativas de São Paulo votação acima de 50\%. Ele manteve os redutos eleitorais situados na região do Vale do Paraíba, incluindo sua cidade natal, Pindamonhangaba. Comparado a 2002, sua votação diminuiu drasticamente nos arredores da capital.

O tucano também perdeu votos em municípios do sul e do leste, apresentando uma votação mais esvaziada nessas localidades, principalmente no extremo sul, assim como ocorreu nos municípios localizados a noroeste - próximos à fronteira de Minas Gerais - e a oeste - próximos a Mato Grosso do Sul. Conforme mostrado anteriormente, Alckmin teve uma votação menor que a conquistada por Serra em 2006 e, comparado à sua eleição em 2002, perdeu redutos eleitorais significativos. Uma das hipóteses para isso é a de que Alckmin foi prejudicado pelo seu afastamento da política, que ocorreu após duas derrotas seguidas: para presidente da República em 2006 e para prefeito da capital em 2008 . 


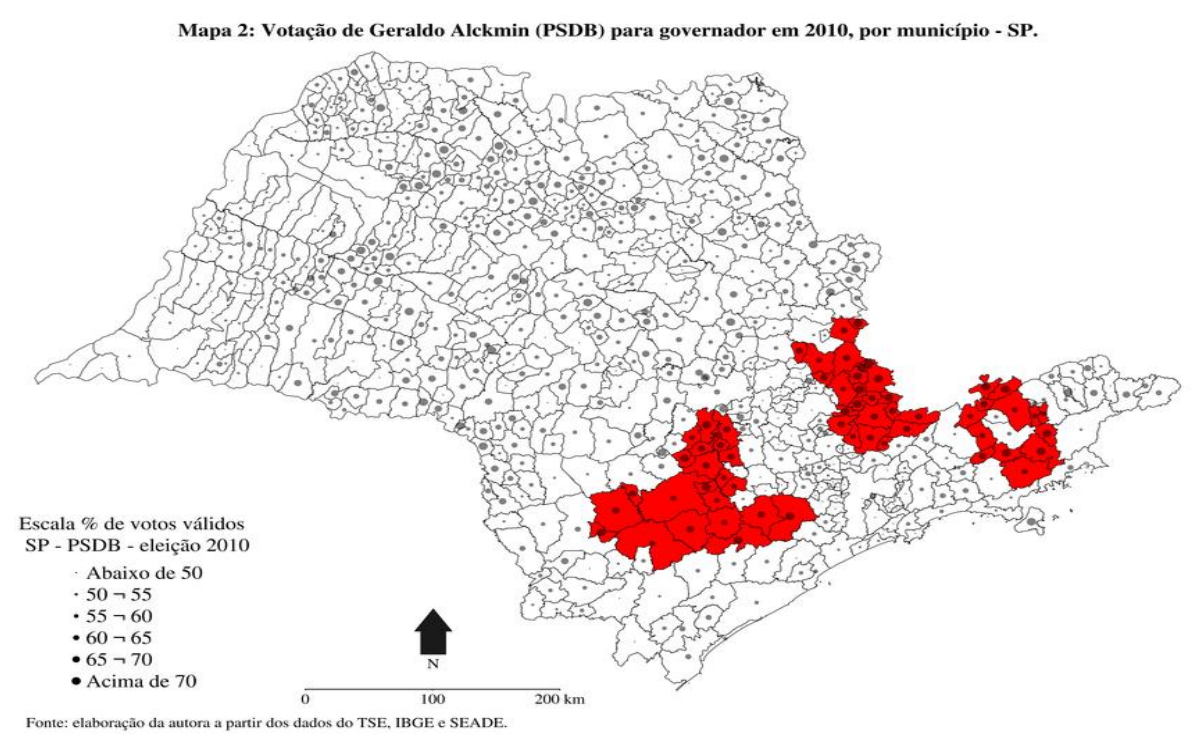

Alckmin, nas eleições de 2014, contou, assim como nas anteriores, com uma votação bem distribuída por São Paulo. A diferença foi que nesse pleito a porcentagem de votos acima de $65 \%$ se espalhou pelo estado - regiões destacadas em vermelho - de uma forma que não havia acontecido antes, fato que, juntamente com a presença na disputa de candidatos com pouca expressividade, facilitou a sua vitória no primeiro turno.

Os municípios interior a dentro de São Paulo representaram redutos eleitorais ainda não vistos nas eleições anteriores, como aconteceu especialmente com os municípios localizados a noroeste do estado. Observa-se que nas três eleições, Alckmin manteve praticamente intacto apenas o reduto ao leste do estado, que engloba municípios situados na Serra da Mantiqueira, como Bragança Paulista, Serra Negra e Campos do Jordão.

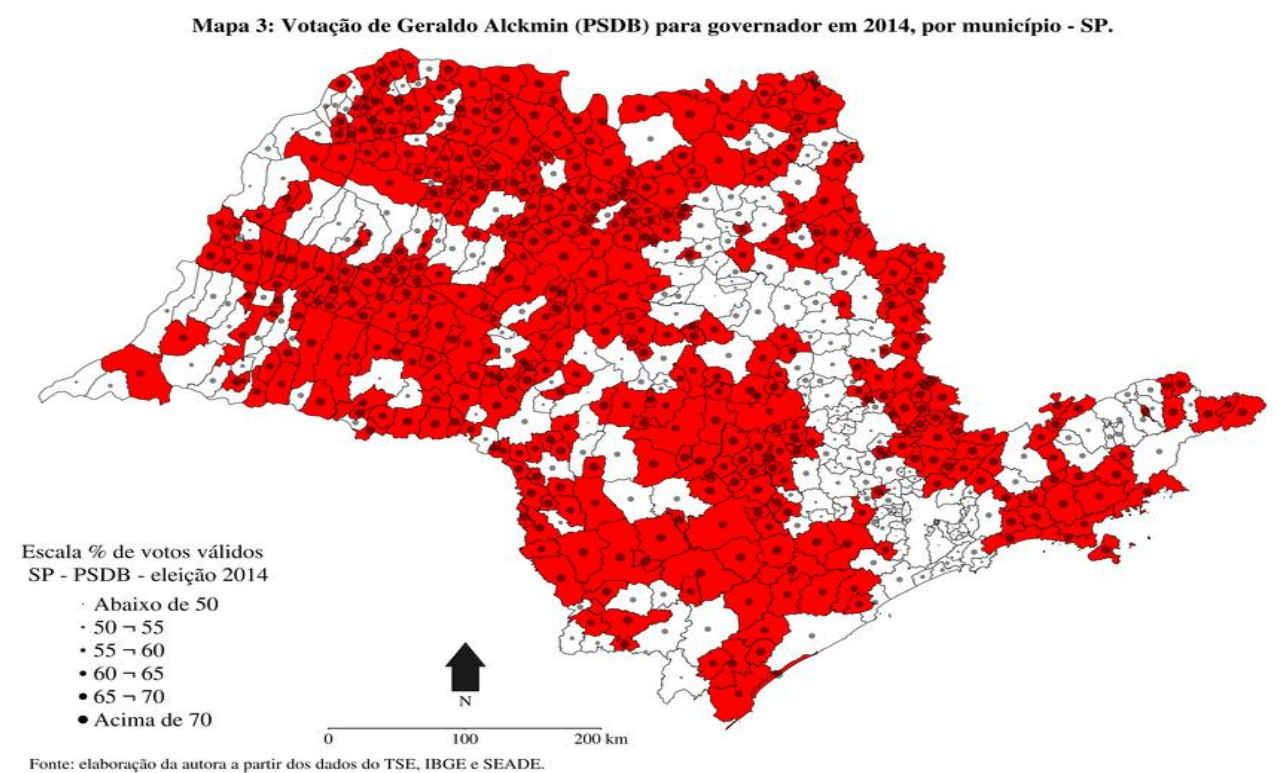




\subsection{Resultados de regressões e mapas}

Os resultados das regressões estatísticas derivaram da estimativa dos coeficientes associados a cada variável e do teste posterior, que revelou se os valores encontrados eram estatisticamente significativos ou não. Os valores de $p$ foram considerados significativos abaixo de 0,05 , conforme pode ser observado na tabela 3 , abaixo.

Tabela 3 - Resultados dos modelos lineares generalizados (GLM) por ano eleitoral ${ }^{1}$

\begin{tabular}{|c|c|c|c|c|c|}
\hline Modelo & Variáveis & Coeficientes & Erro padrão & $t$ & $p$ \\
\hline \multirow[t]{7}{*}{ Eleição 2002* } & Intercepto & 80,108 & 6,145 & 13,036 & $<0,001$ \\
\hline & Anos de estudo (2000) & $-1,916$ & 0,489 & $-3,914$ & $<0,001$ \\
\hline & IDHM - dimensão renda (2000) & $-36,341$ & 7,722 & $-4,706$ & $<0,001$ \\
\hline & Índice de envelhecimento & 0,143 & 0,023 & 6,087 & $<0,001$ \\
\hline & Índice de Gini (2000) & 32,409 & 5,742 & 5,644 & $<0,001$ \\
\hline & Partido do prefeito & $-0,364$ & 0,611 & $-0,595$ & 0,552 \\
\hline & Log (prop. empregos formais) & 0,156 & 0,709 & 0,220 & 0,826 \\
\hline \multirow[t]{8}{*}{ Eleição 2010** } & Intercepto & 144,411 & 11,641 & 9,828 & $<0,001$ \\
\hline & Anos de estudo & $-1,808$ & 0,458 & $-3,945$ & $<0,001$ \\
\hline & IDHM - dimensão renda & $-90,561$ & 18,015 & $-5,027$ & $<0,001$ \\
\hline & Índice de envelhecimento & 0,145 & 0,017 & 8,379 & $<0,001$ \\
\hline & Índice de Gini & 23,855 & 8,410 & 2,836 & $<0,01$ \\
\hline & Partido do prefeito & $-0,227$ & 0,675 & $-0,337$ & 0,736 \\
\hline & Log (prop. empregos formais) & 3,660 & 0,808 & 4,531 & $<0,001$ \\
\hline & Proporção Bolsa Família & $-0,910$ & 0,310 & $-2,929$ & $<0,01$ \\
\hline \multirow[t]{8}{*}{ Eleição 2014*** } & Intercepto & 66,668 & 4,873 & 13,681 & $<0,001$ \\
\hline & IPRS - dimensão escolaridade (2012) & 0,113 & 0,051 & 2,219 & $<0,05$ \\
\hline & IPRS - dimensão riqueza (2012) & $-0,626$ & 0,075 & $-8,329$ & $<0,001$ \\
\hline & Índice de envelhecimento & 0,034 & 0,015 & 2,288 & $<0,05$ \\
\hline & Índice de Gini (2010) & 9,993 & 5,441 & 1,836 & $<0,1$ \\
\hline & Partido do prefeito & $-0,606$ & 0,624 & $-0,971$ & 0,332 \\
\hline & Log (prop. empregos formais) & 3,985 & 0,888 & 4,486 & $<0,001$ \\
\hline & Proporção Bolsa Família & $-0,392$ & 0,210 & $-1,861$ & $<0,1$ \\
\hline
\end{tabular}

${ }^{1}$ Todos os valores significativos a $\mathrm{p}<0,05$.

* Resultados do modelo para 2002: $\left(\mathrm{F} 6,634=14,62, p<0,001, \operatorname{Radj}^{2}=0,11\right)$.

** Resultados do modelo para 2010: $\left(\mathrm{F} 7,636=13, p<0,001, \operatorname{Radj}^{2}=0,11\right)$.

*** Resultados do modelo para 2014: $\left(\mathrm{F} 7,636=21,49, p<0,001, \operatorname{Radj}^{2}=0,18\right)$.

Fontes: TSE, IBGE, SEADE e processamento da autora.

Ao se analisar os resultados do modelo relativo ao ano de 2002, no qual ocorreu a primeira eleição de Alckmin para o governo de São Paulo, quatro variáveis se 
mostraram estatisticamente significantes: anos de estudo (2000), IDHM-dimensão renda (2000), índice de Gini (2000) e índice de envelhecimento. Mantendo-se constantes todas as demais variáveis do modelo, tem-se que, quanto maior foi o nível de escolaridade da população do município, a proporção de votos no candidato tucano tendeu a diminuir, demonstrando uma relação inversamente proporcional entre anos de estudo e voto nessa eleição. O mesmo efeito teve o IDHM-dimensão renda sobre o voto em Alckmin: quanto maior foi o IDHM-Renda no município em 2002, menor se apresentou a votação no psdebista. Nesse sentido, infere-se que municípios com menor nível educacional e menor renda se mostraram mais favoráveis ao voto em Alckmin na sua primeira eleição para o Executivo paulista.

No mapa 4, abaixo, onde está plotada a variável anos de estudo e a votação de Alckmin no segundo turno de 2002, apesar de não ser possível observar uma relação geográfica clara entre essas duas variáveis, tendo em vista a dispersão da votação nesse ano, verifica-se que em algumas regiões os municípios que possuíam menor escolarização - os de cor mais clara - apresentaram maior votação em Alckmin. Isso pode ser observado principalmente nos municípios ao leste próximos a Campinas (Socorro, Pedra Bela, Tuiuti, Joanópolis e Bom Jesus dos Perdões), na região do Vale do Paraíba (São Bento do Sapucaí, Santo Antônio do Pinhal e Silveiras) e ao sul do estado (Itariri, Miracatu, Juquitiba, Ibiúna, Piedade e Tapiraí). Menor votação no psdebista foi encontrada nos municípios com maior escolaridade, localizados especialmente no centro e no norte do estado, bem como na região metropolitana.

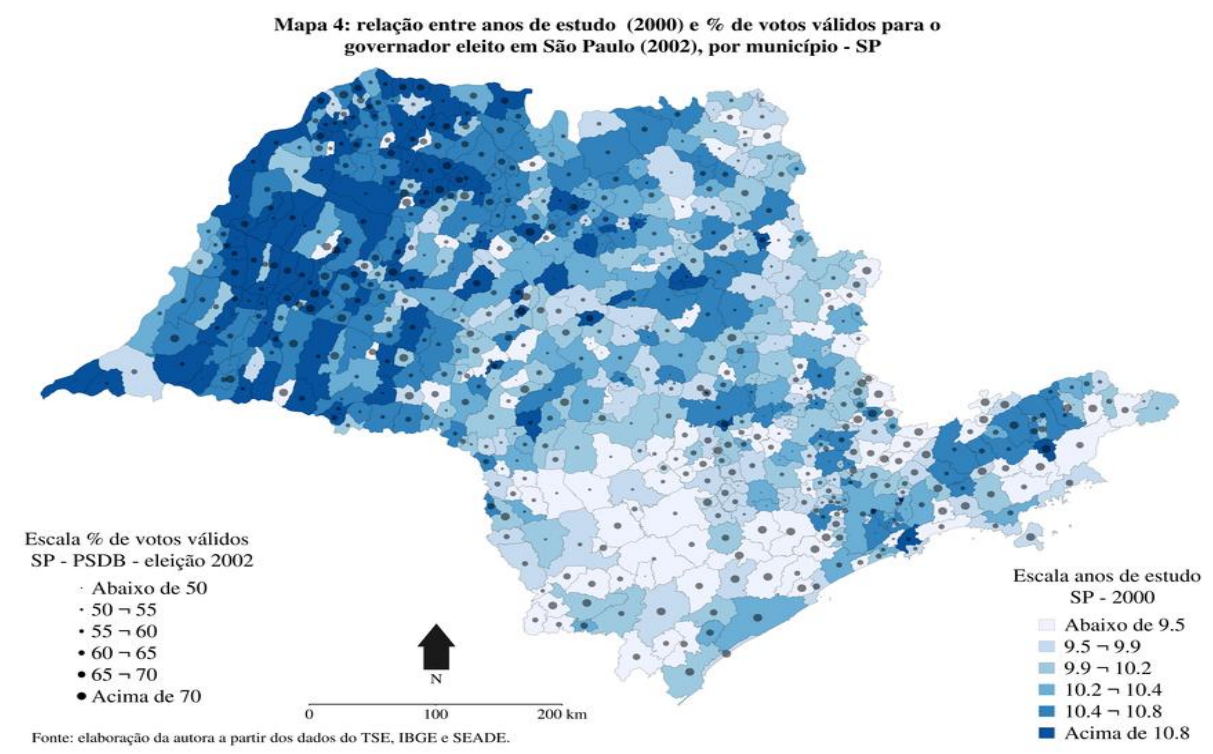


As regiões de maior escolarização em 2002 tiveram destaque eleitoral na votação do petista José Genoíno, adversário de Alckmin no segundo turno, conforme aponta o trabalho já citado de Storni (2010). Nessa eleição, a captação pelo PT de votos da população mais escolarizada em São Paulo foi um fenômeno que ocorreu em todo o Brasil com a candidatura de Lula ao Planalto.

Limongi e Guarnieri (2015), utilizando dados de escolaridade dispostos no cadastro eleitoral, apontam que entre 1998 e 2002 o PT avançou sobre o eleitorado mais escolarizado, apresentando um baixo desempenho entre os grupos mais desfavorecidos do que entre os demais. Segundo os autores, foi a partir da eleição de 2006 que o partido passou “(...) a ser sobrevotado entre os menos escolarizados (leia-se "os de menor renda") e subvotado entre os mais escolarizados (leia-se "os de maior renda")" (LIMONGI; GUARNIERI, 2015, p. 79). Ponderando que o uso de dados agregados não nos permite tirar conclusões sobre o comportamento do eleitor em si, os autores, ainda assim, fazem essa observação considerando o ponto de vista da composição do voto petista.

No mapa 5, pode-se observar a tendência do aumento da votação em Alckmin em 2002 nos municípios que tinham IDHM-Renda mais baixo, principalmente naqueles que possuíam essa característica e se localizam no interior e no sul. A exceção está nos municípios do leste do estado que possuíam alto IDHM-Renda, onde o tucano recebeu boa votação, como Campos do Jordão, Pindamonhangaba (sua cidade natal), São José dos Campos, Caçapava, Taubaté, Bragança Paulista, Socorro, Águas de Lindoia e Monte Alegre do Sul.

Novamente, os municípios do centro e do norte, que possuíam alto IDHMRenda, destacaram-se na votação em Genoíno, como aqueles das regiões administrativas de Ribeirão Preto (Pontal, Pitangueiras, Sertãozinho e Jaboticabal), Central (Matão, Araraquara e São Carlos), Campinas (Pedreira, Jaguariúna, Paulínia, Sumaré, Limeira e Araras) e nos municípios a sudeste da capital (São Caetano do Sul, Diadema, São Bernardo do Campo, Santo André, Mauá e Ribeirão Pires). 


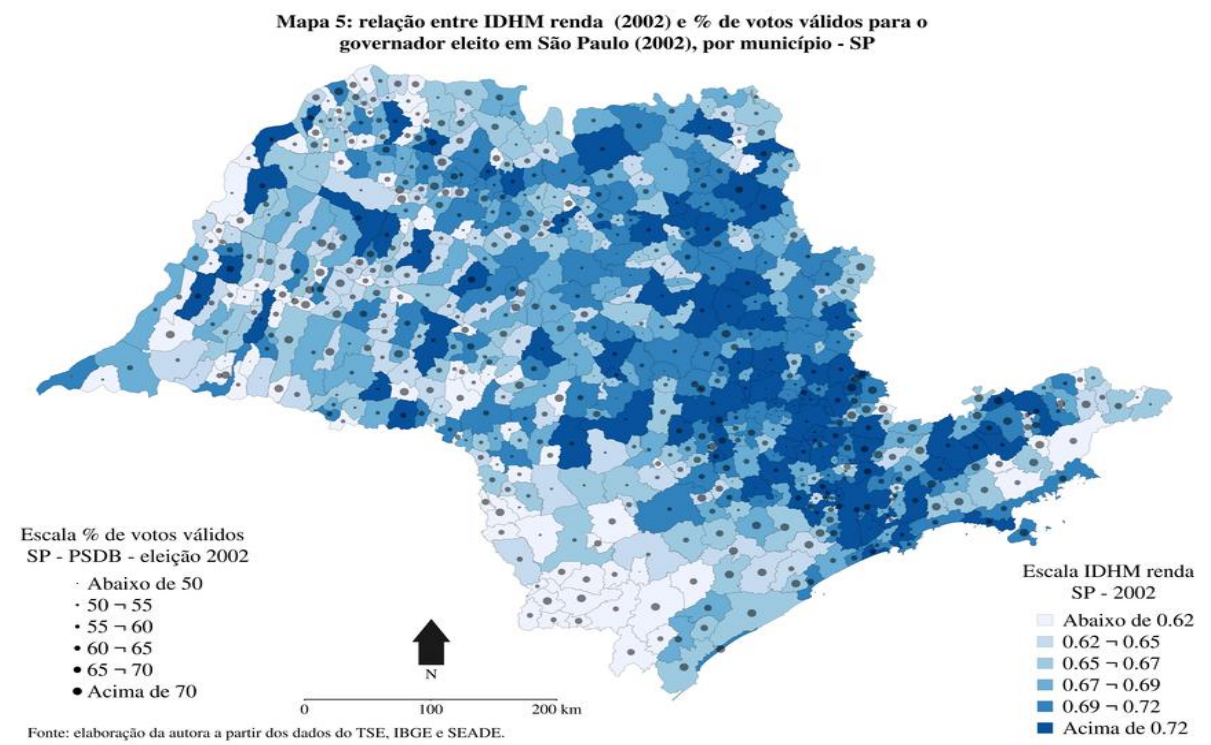

O modelo estatístico de 2002 evidencia ainda que quanto maior foi o índice de Gini municipal, maior se mostrou a proporção de votos no candidato, mantendo-se as outras variáveis constantes. Ou seja, municípios com maior concentração de renda e, por consequência, com populações mais desiguais entre si, apresentaram nesse ano uma maior proporção de votos em Alckmin. Foi o caso, por exemplo, do sul do estado, incluindo Cananeia, Barra do Turvo, Jacupiranga, Registro, Iguape, Apiaí, Iporanga e Itacaré, bem como daqueles municípios que se localizam no leste, conforme se pode observar no mapa 6.

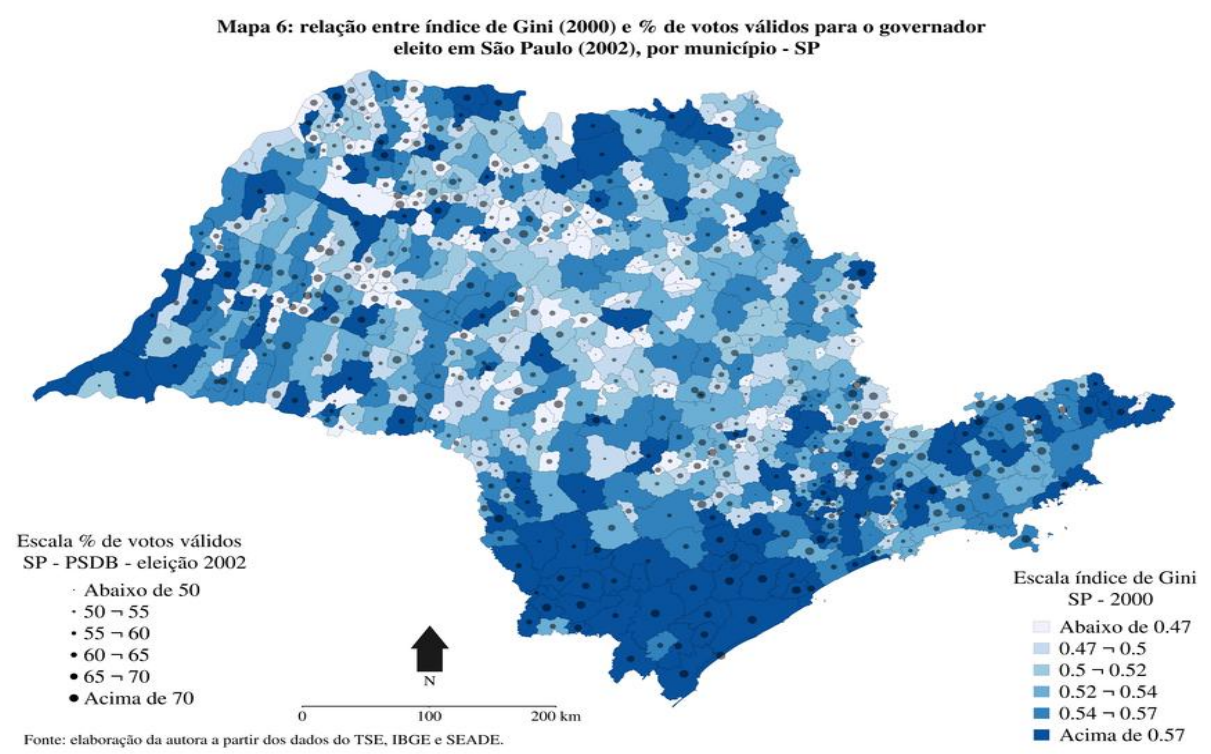

Ressalta-se que alguns municípios que apresentaram baixa renda e alto índice de desigualdade foram aqueles nos quais Alckmin mais ganhou no segundo turno, como no caso dos municípios ao sul do estado. Isso vai ao encontro da ideia de Limongi e Guarnieri 
(2015) de que em 2002, ao contrário dos tucanos, o PT avançou sobre os mais ricos, eleitorado considerado genericamente do PSDB.

O mesmo efeito diretamente proporcional também aconteceu com o índice de envelhecimento: quanto maior se mostrou o grau de envelhecimento no município houve um aumento na votação em Alckmin.

No mapa 7, verifica-se, de modo geral, que os municípios interioranos com população mais idosa apresentam votação maior em Alckmin em comparação com os municípios mais jovens localizados especialmente na região metropolitana e no centro do estado. Mesmo que não seja possível inferir o perfil do eleitor a partir de dados agregados, em termos da composição do voto psdebista é possível dizer que, em 2002, parte significativa do eleitorado mais velho tenha optado pelo voto em Alckmin. Uma das hipóteses para isso é que o eleitor mais velho tenha escolhido aquilo que já era conhecido, dado o seu espírito normalmente mais conservador ou tradicionalista.

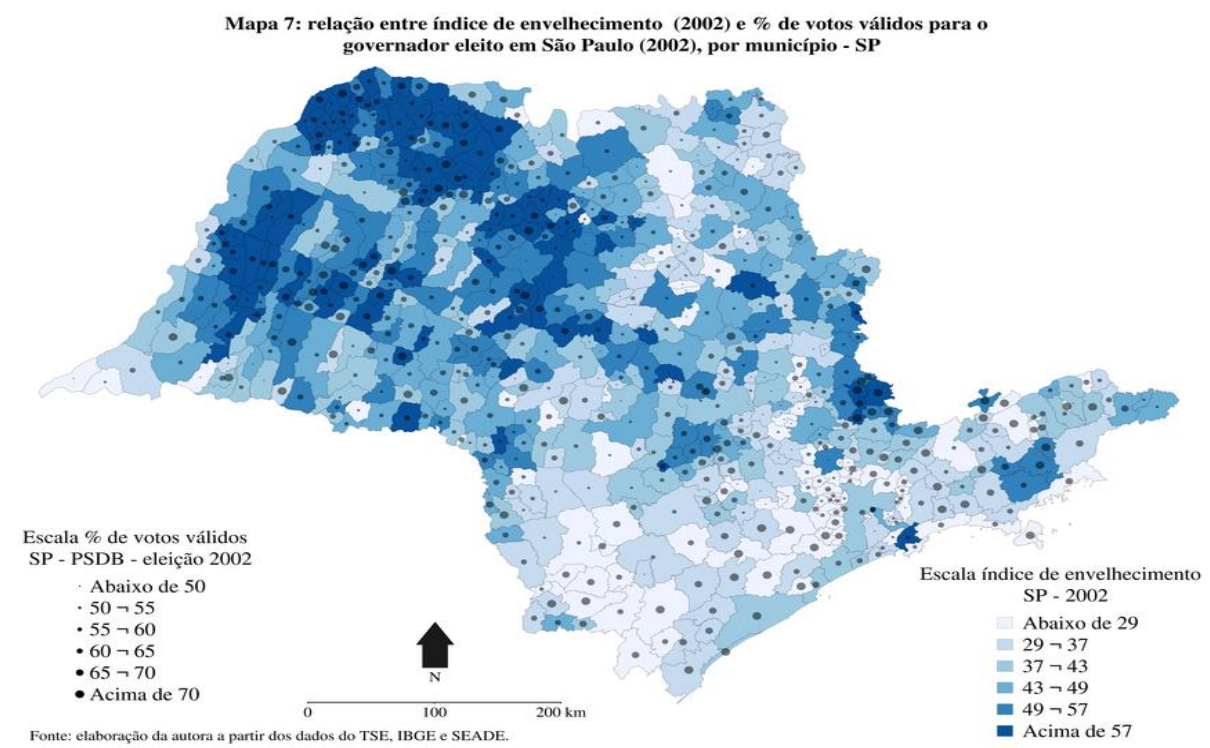

Com efeito, mesmo que Alckmin tenha sido em parte um candidato novo nessa eleição, seu partido já estava no poder há oito anos, e considerando que ele tinha sido o vice-governador nos dois mandatos do seu antecessor, o tucano Mário Covas, é provável que o eleitor mais idoso o tenha visto como sinônimo de continuidade.

Outra possibilidade é a de que esses eleitores tenham votado em Alckmin por quererem, antes de qualquer coisa, ordem. Com a saída de Paulo Maluf da disputa nesse ano, candidato que tinha um discurso duro sobre violência e segurança e contava com a aceitação principalmente dos mais velhos, é provável que Alckmin, no segundo turno, haja 
sido o preferido por essa parte do eleitorado, já que aderiu a um discurso sobre violência semelhante ao de Maluf, embora esse tenha apoiado o petista José Genoíno.

O filósofo britânico Michael Oakeshott via a "disposição conservadora” ligada ao tempo presente devido à relação de familiaridade que o indivíduo estabelece com aquilo que existe e é positivo. Nesse sentido, para ele, o conservadorismo está mais relacionado com aquilo que pode ser palpável no agora do que com a exaltação de um passado glorioso. O medo da mudança imputado aos conservadores existe, segundo Oakeshott, na medida em que a transformação é vista, não necessariamente como algo que traz progresso e melhoria, mas sim como uma ameaça à identidade, àquilo que se conquistou e é familiar. Portanto, "ser conservador [...] é preferir o familiar ao desconhecido, preferir o experimentado ao não experimentado, o fato ao mistério, o real ao possível, o limitado ao ilimitado, o próximo ao distante, o suficiente ao superabundante, o conveniente ao perfeito, um presente alegre a uma felicidade utópica" (OAKESHOTT, 1991, p. 408).

Os resultados obtidos pelo modelo referente às eleições de 2010 mostraram que as mesmas variáveis do modelo de 2002 tiveram significância estatística - anos de estudo, IDHM- Renda, Gini e índice de envelhecimento -, adicionando-se a relevância da variável logaritmo de empregos formais e da proporção de famílias que recebiam o Programa Bolsa Família (PBF). Em 2010, assim como ocorreu em 2002, anos de estudo e IDHM-Renda se mostraram inversamente proporcionais à votação em Alckmin. Municípios com menor nível de escolarização e menor renda apresentaram maior tendência no voto no psdebista.

No mapa 8, abaixo, observa-se que nos municípios a noroeste e a oeste do estado, que apresentam maior escolaridade, Alckmin obteve menor votação. Quanto à visualização geográfica da votação em relação ao IDHM-Renda (mapa 9), apesar de não ser possível observar um padrão visual definido, verifica-se que algumas regiões que possuíam municípios com maior IDHM-Renda, como aqueles localizados na Baixada Santista e ao redor da capital e de Campinas, como é o caso de Pedreira, Jaguariúna, Paulínia, Americana, Sumaré, Hortolândia e Indaiatuba, apresentaram votação menor em Alckmin. 

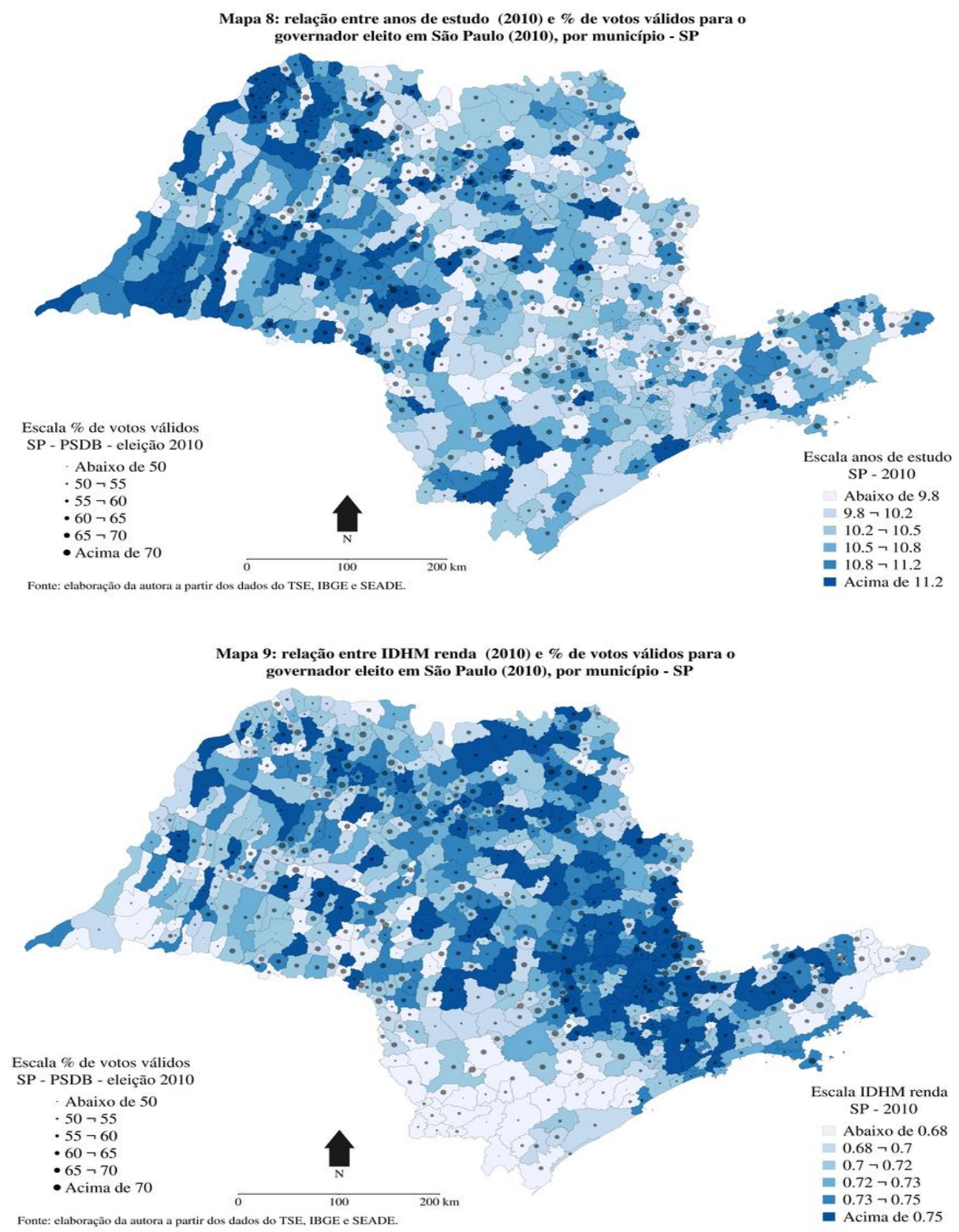

O índice de Gini em 2010 também possui o mesmo efeito de 2002: quanto maior foi a desigualdade de renda no município, tendeu a crescer o voto em Alckmin, mantendo-se ambas as variáveis constantes. Verifica-se ainda, conforme pode ser notado no mapa 10, a tendência, em algumas regiões, de municípios que tinham alto índice de Gini apresentarem maior votação em Alckmin. Esse é o caso de municípios localizados ao nordeste e ao leste do estado, que fazem fronteira com MG, como aqueles que rodeiam Bragança Paulista - Pedra Bela, Pinhalzinho, Tuiuti, Amparo e Atibaia, bem como aqueles que compõem o Vale do Paraíba - São Bento do Sapucaí, Campos do Jordão, Guaratinguetá, Pindamonhangaba e Lavrinhas. 


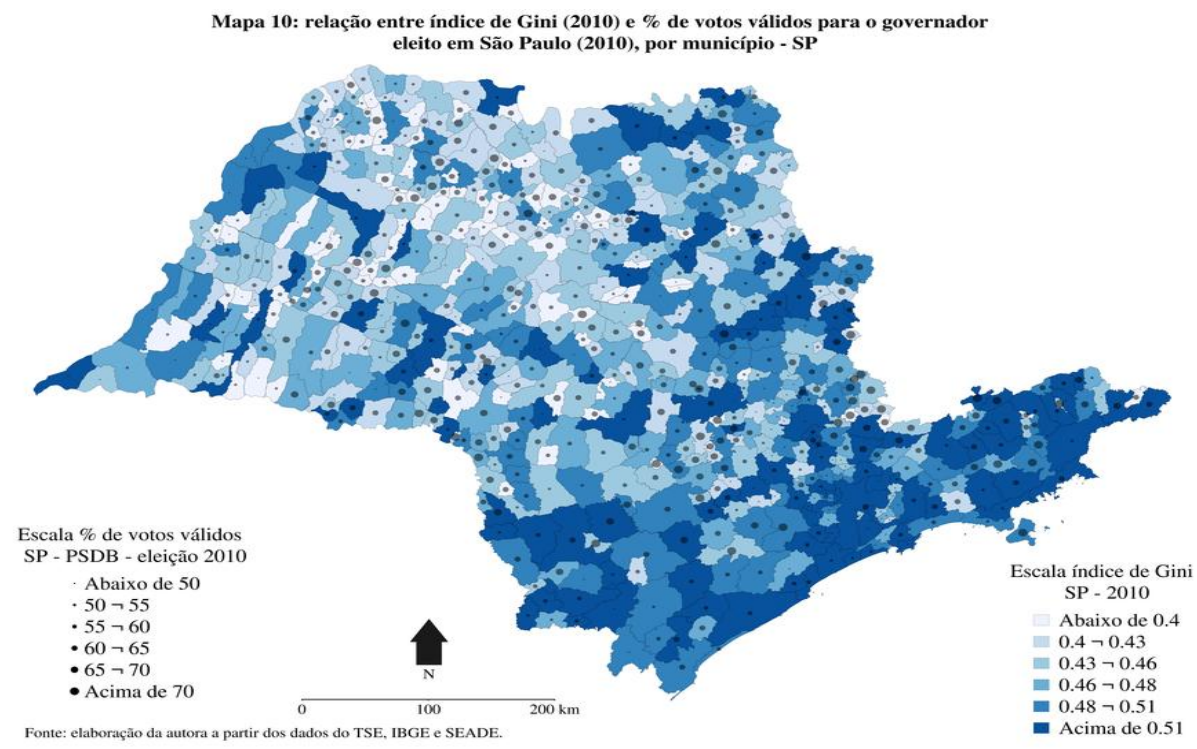

O efeito do índice de envelhecimento também pode ser interpretado da mesma forma que em 2002. O aumento da população mais velha no município tendeu a acarretar o crescimento da proporção de votos em Alckmin na eleição de 2010. Embora não seja um padrão geográfico, observa-se no mapa 11 que nos municípios com grau de envelhecimento maior, especialmente localizados no interior de SP, Alckmin obteve uma votação maior que nos municípios mais jovens, como os da região metropolitana de São Paulo e da Baixada Santista.

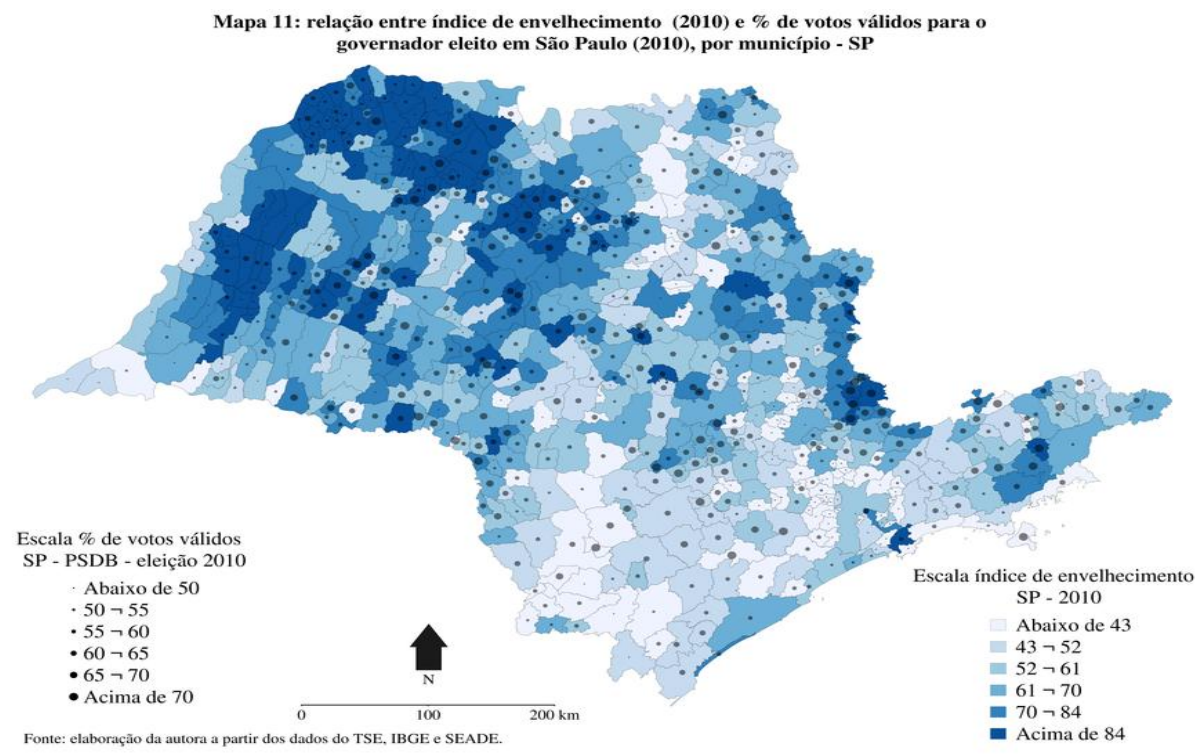

Segundo o colunista Hélio Schwartsman, a hegemonia tucana em São Paulo nas eleições de 2010 tinha como uma de suas causas o elemento demográfico do estado: "mais adultos e menos crianças equivalem a mais renda e menos despesas, o que contribui 
para um "fell good fator" que vem beneficiando o PSDB. (...) o próprio envelhecimento da população resulta num voto mais conservador. Em geral, são os jovens e os que sentem não estar avançando que arriscam votos heterodoxos" ${ }^{\text {"14 }}$. O mesmo argumento que direciona para o conservadorismo dos mais velhos foi utilizado anteriormente como uma possibilidade de explicação para a relevância estatística dos municípios com maior índice de envelhecimento na votação em Alckmin em 2002.

A variável logaritmo da proporção de empregos formais em 2010 também contribuiu de forma positiva para a votação no governador. Tem-se que, fixando as demais variáveis, quanto maior foi a proporção de empregos formais no município, a proporção de votos no tucano aumentou. Observa-se mais nitidamente nos municípios do extremo sul do estado, onde a proporção de empregos formais é menor, que a votação em Alckmin também foi menor (mapa 12). A estabilidade proporcionada pelo emprego formal pode fazer com que os eleitores empregados votem mais no candidato governista do que o contrário.

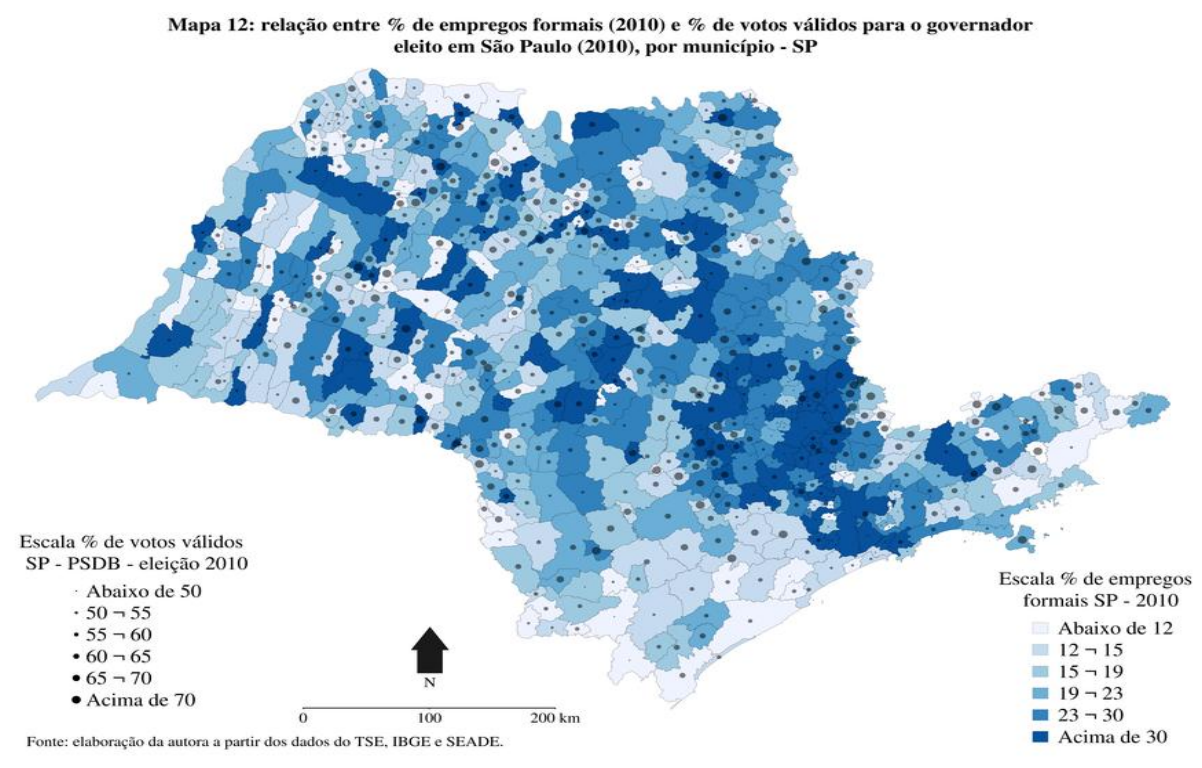

O mesmo efeito não ocorre quando se considera a variável proporção de famílias que recebiam o Bolsa Família no município. Conforme essa proporção aumentou, a quantidade de votos em Alckmin tendeu a diminuir, mantendo constantes as demais variáveis.

\footnotetext{
${ }^{14}$ Em Folha de S. Paulo, Especial Eleições 2, 4 de outubro de 2010, p. 2.
} 
Observa-se no mapa 13 que essa tendência se verifica, por exemplo, nos municípios ao sul do estado, como Barra do Turvo, Eldorado, Iporanga e Ribeirão Branco, localizados na mesma região que em 2002 apresentou maior concentração de renda, e naqueles do extremo oeste, como Rosana, Euclides da Cunha Paulista, Presidente Epitácio e Presidente Prudente. A importância do Bolsa Família ocorreu tanto para os candidatos petistas a governador quanto para o candidato do partido à Presidência da República.

Limongi e Guarnieri (2015) mostram que em São Paulo, nas eleições de 2006, a relação entre voto em Lula e Bolsa Família é mais direta que, por exemplo, no Maranhão. Isso significa que no caso maranhense, mesmo nas localidades onde a cobertura do PBF era baixa, Lula obteve bons resultados, ao passo que em São Paulo, "quanto mais famílias no Programa, maior a votação em Lula. [Já] Nos municípios [paulistas] onde não há famílias cobertas pelo Programa, a vantagem de Alckmin sobre Lula é superior a 30\%" (LIMONGI; GUARNIERI, 2015, p. 73).

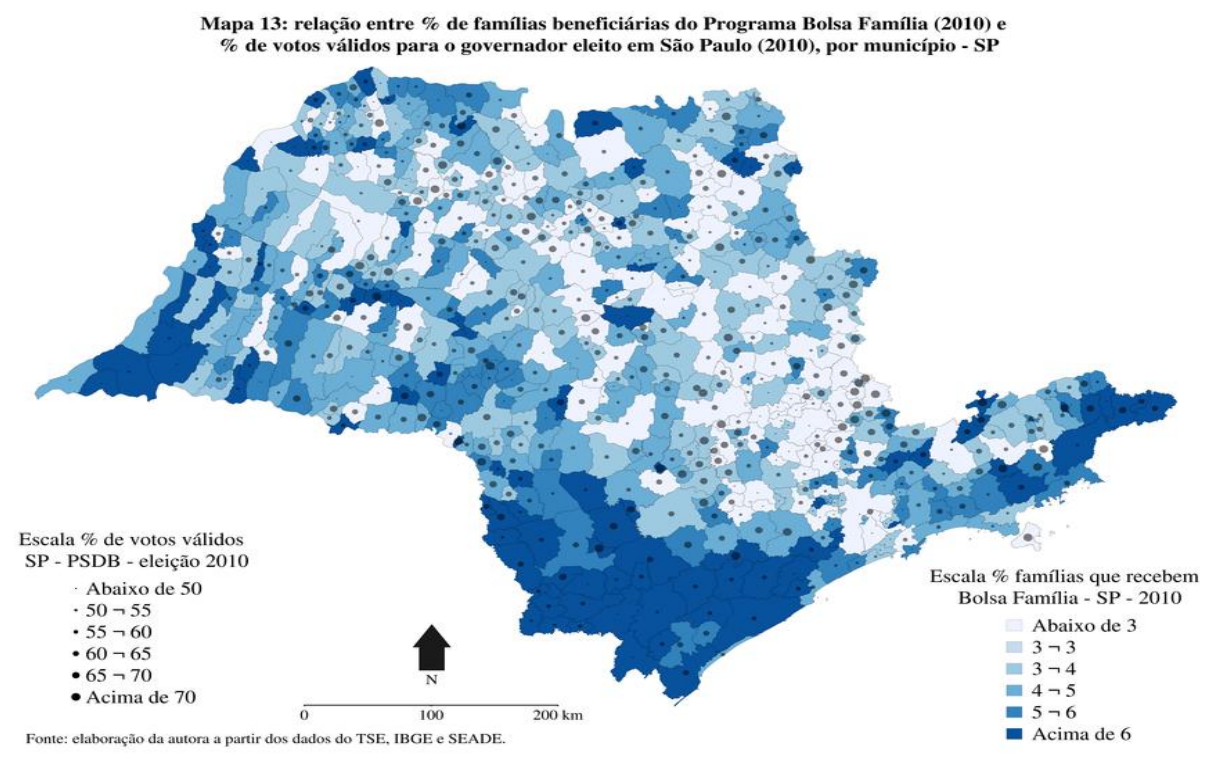

No modelo feito para 2014, apenas a variável relativa ao partido do prefeito não apresentou nenhuma significância estatística. A variável IPRS-Escolaridade teve efeito contrário ao demonstrado pela variável anos de estudo utilizada nos modelos de 2002 e 2010, embora tenha apresentado, quando comparada a essa, um grau de significância menor. A tendência é que quanto maior foi o IPRS-Escolaridade no município em 2014, maior haja sido a votação em Alckmin, mantidas as demais variáveis constantes, o que não tinha sido observado nas outras eleições. 
Exemplo disso, conforme pode ser observado no mapa 14, é a diferença que há entre a votação de Alckmin nos municípios a noroeste do estado, com maior escolaridade, e os municípios a sudeste, incluindo a capital, com menor nível educacional. O efeito distinto de escolaridade sobre a votação de Alckmin nas eleições de 2014 em comparação com os outros anos evidencia que o apoio eleitoral de uma ou outra parcela da população não é imutável entre eleições, e que certamente fatores temporais como a conjuntura econômica e/ou política podem alterá-lo.

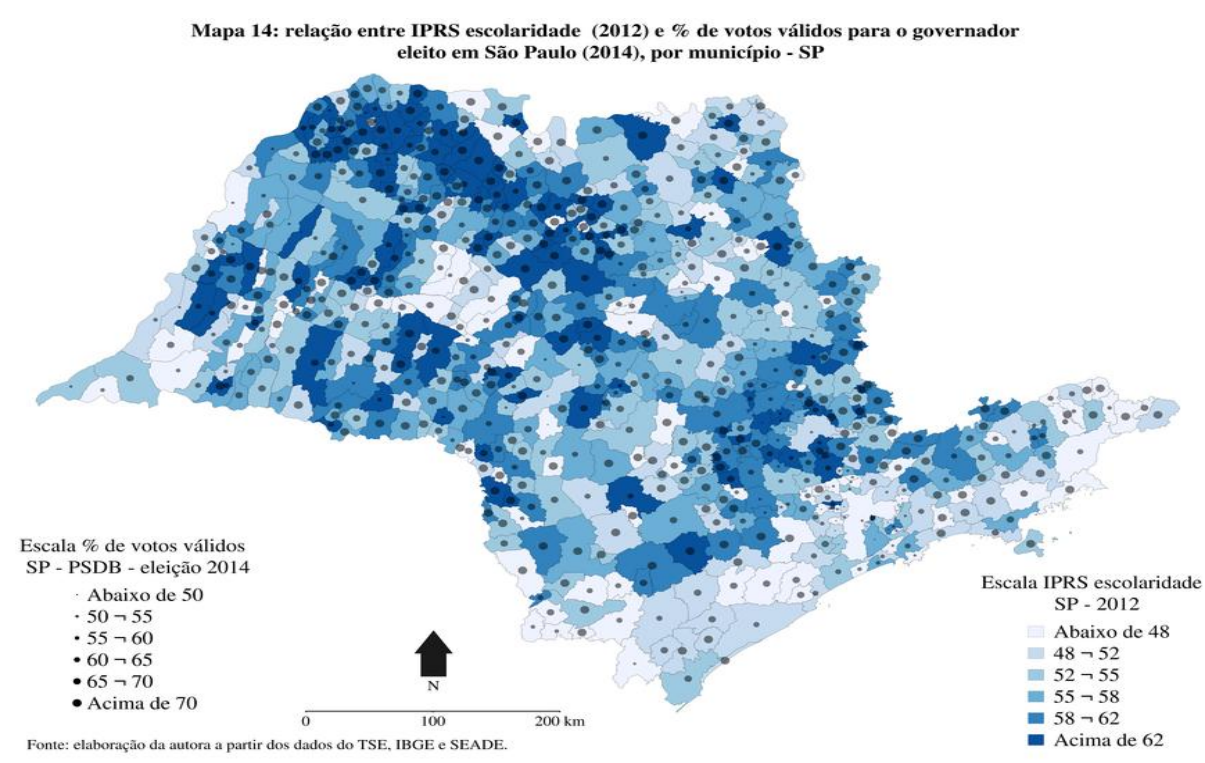

Em 2014, percebe-se que a votação do psdebista cresceu por todo o estado mais que nos pleitos anteriores. É clara a indicação de que ele aumentou sua votação nas regiões mais escolarizadas que chegaram a pertencer ao PT, partido que perdeu seus redutos eleitorais nesse ano por, provavelmente, dois motivos: i) ter emplacado a candidatura de Alexandre Padilha, que não era conhecido e nunca tinha disputado nenhuma eleição; ii) em 2014 agravou-se a crise do partido, iniciada no primeiro mandato de Lula com o escândalo do mensalão, principalmente no governo federal, o que deve ter repercutido no âmbito estadual.

Já as variáveis IPRS-Renda, que substituiu IDHM-Renda, índice de envelhecimento e logaritmo da proporção de empregos formais tiveram o mesmo efeito na proporção de votos que o resultado obtido em 2002 e 2010. Os municípios de maior renda também em 2014 se mostraram menos favoráveis ao voto em Alckmin.

A região metropolitana de São Paulo é um exemplo dessa relação inversamente proporcional, assim como os municípios que rodeiam a parte oeste de Campinas, como 
Paulínia, Sumaré, Hortolândia e Santa Bárbara d'Oeste, conforme mostra o mapa 15. O contrário ocorreu, em geral, nos municípios do interior do estado que possuíam menor renda - regiões claras do mapa - e apresentaram grande votação em Alckmin. Tradicionalmente, as regiões que englobam a capital e Campinas apresentam votações menores em Alckmin. No entanto, não se pode asseverar que tais municípios e seus arredores ampliaram nesse ano a votação dos adversários do tucano, porque ele obteve a maior proporção de votos válidos em todos eles, em comparação com seus concorrentes.

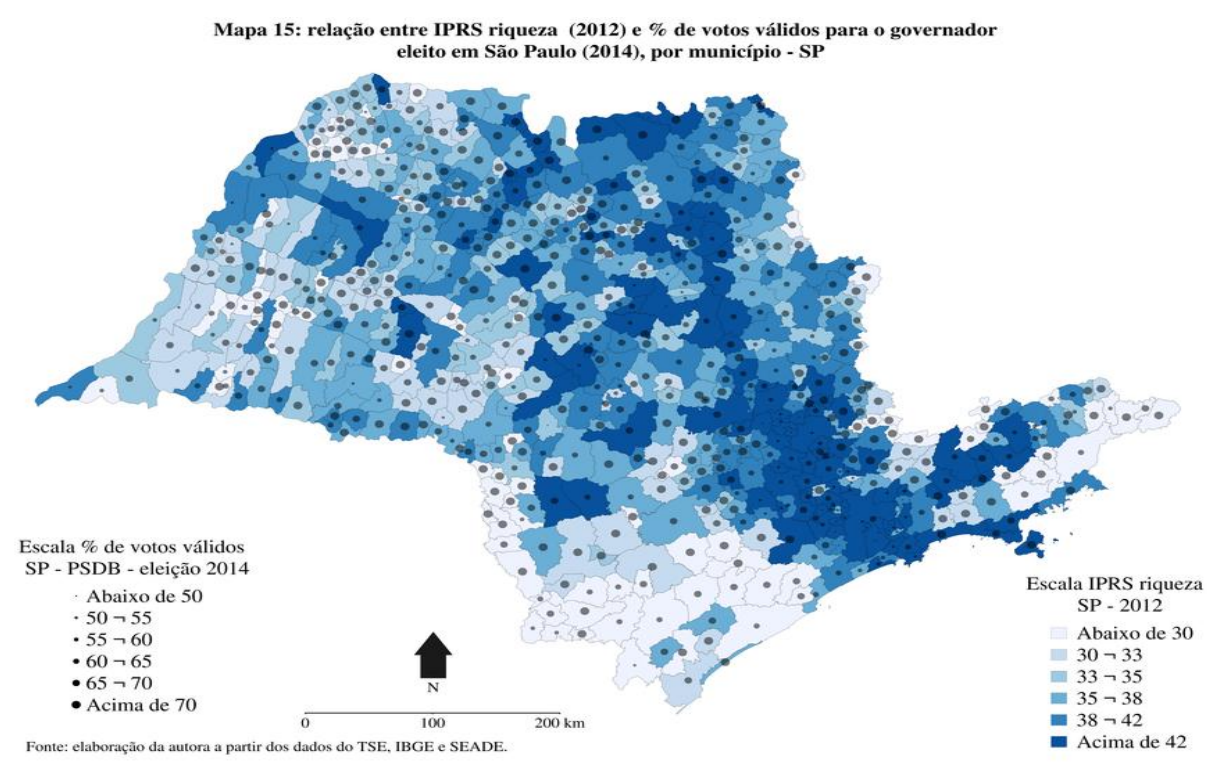

O índice de Gini relativo ao ano de 2010, utilizado em 2014 como forma de controle, bem como a proporção de famílias que recebiam o PBF apresentaram um baixo grau de significância estatística quando comparadas às demais variáveis que apresentaram relevância nesse modelo. Apesar disso, tiveram os mesmos efeitos sobre a votação em Alckmin que aqueles evidenciados nas regressões anteriores. Infere-se, em 2014, que quanto maior foi o índice de Gini no município, maior foi a proporção de votos em Alckmin.

Além disso, mantendo as demais variáveis fixas, a tendência é que quanto maior foi a proporção de famílias beneficiadas pelo PBF no município em 2014, menor haja sido a proporção de votos no candidato do PSDB, como se observa em alguns municípios do oeste do estado. Ressalta-se, no entanto, que na última eleição, a votação em Alckmin aumentou nos municípios com maior cobertura do PBF, em comparação com 2010, conforme pode ser observado no mapa 16. 
Mais uma vez se evidencia que o PBF não é um determinante de votos no PT, pois nesse ano Alckmin foi capaz de conquistar os votos de eleitores beneficiados com base em outros apelos. Percebe-se que “(...) a estrutura da competição - quais são os candidatos e quais as alianças estaduais que os sustentam - influi no desempenho tanto do PT quanto do PSDB. A base social do eleitorado de um e de outro é definida conjuntamente pela competição pelo voto” (LIMONGI; GUARNIERI, 2015, p. 61).

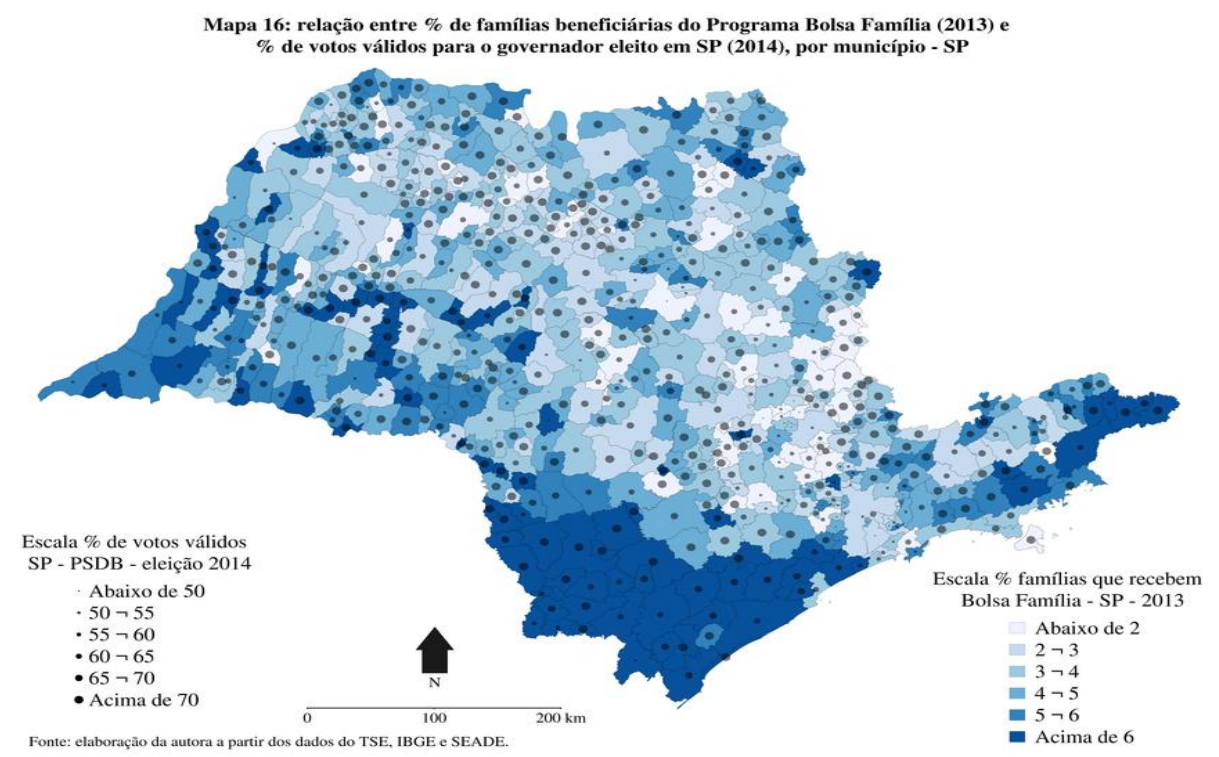

Já quanto maior foi o aumento do índice de envelhecimento e da proporção de empregos formais no município em 2014, maior foi a proporção de votos no tucano. Com relação ao envelhecimento (mapa 17), pode-se notar a diferença de votação entre os municípios do interior, principalmente aqueles a noroeste e a oeste que apresentam população mais idosa - Populina, Mesópolis, Santa Clara d'Oeste, Indiaporã e Araçatuba-, aqueles que rodeiam a capital e que possuem população mais jovem - Caieiras, Guarulhos, Taboão da Serra, Diadema, Ferraz de Vasconcelos e Itaquaquecetuba. 


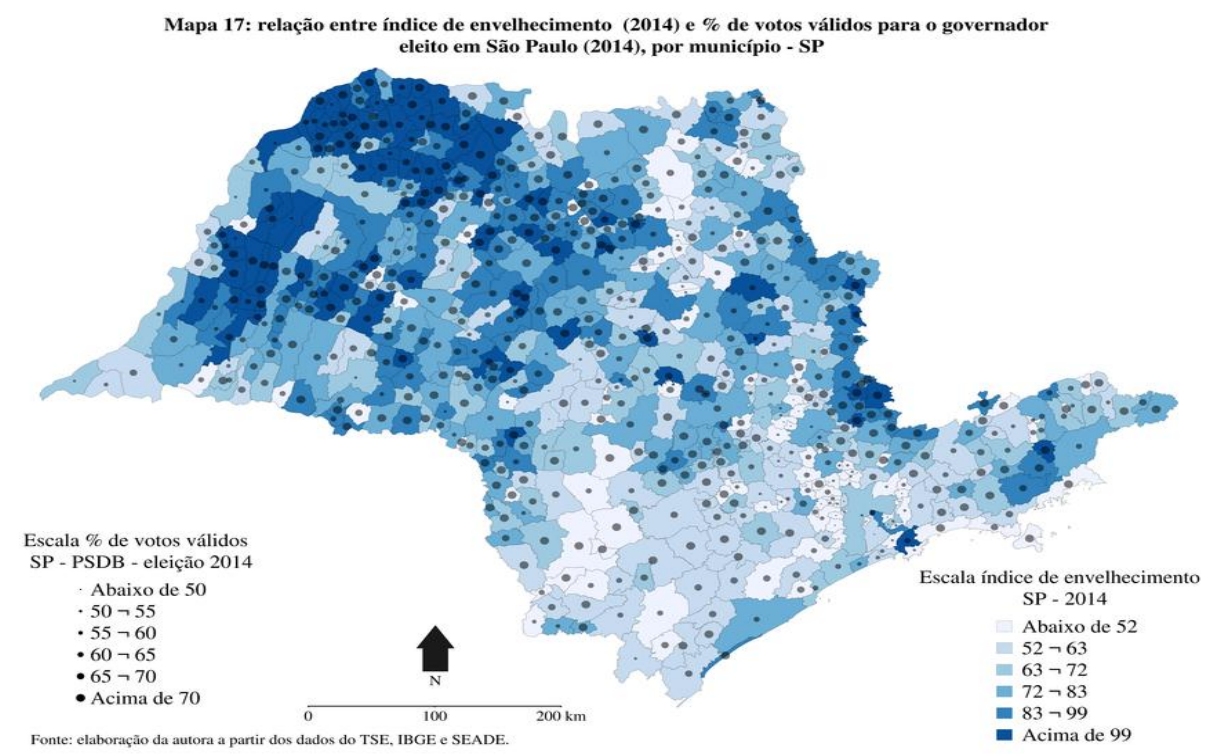

No que se refere à proporção de empregos formais (mapa 18), observa-se maior votação em municípios com alta porcentagem de empregos formais - o que também aconteceu em 2010 -, como aqueles ao norte e ao leste de Campinas, como Jaguariúna, Santo Antônio de Posse, Mogi-Mirim, Morungaba e Itatiba.

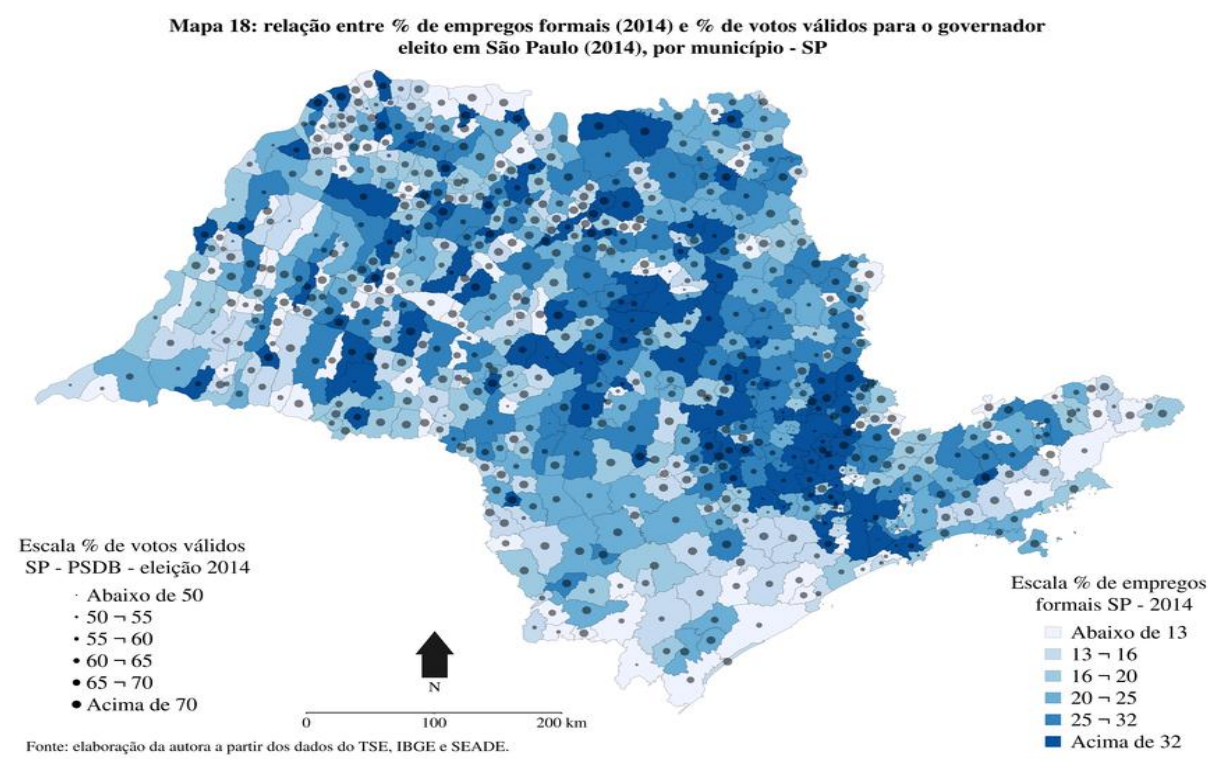

Diante dos resultados evidenciados pelos três modelos, entende-se que Geraldo Alckmin em suas três vitórias para o governo paulista teve sua proporção de votos aumentada nos municípios menos ricos, com maior concentração de renda e entre aqueles que apresentaram população mais idosa. Em 2002 e 2010 sua votação se mostrou maior nos municípios com menor grau de escolaridade, o que não ocorreu em 2014, embora a significância estatística da educação para entender a votação do tucano tenha sido maior nas suas duas primeiras eleições. 
Os municípios que apresentaram maior proporção de empregos formais também contribuíram positivamente para a votação no tucano nas eleições consecutivas de 2010 e 2014. Já os municípios que apresentaram maior proporção de famílias beneficiadas pelo Programa Bolsa Família não se mostraram propensos a votar em Alckmin, o que corrobora a hipótese formulada, baseada em estudos anteriores que asseguram que o PBF pode afugentar o voto nos candidatos e partidos que não o criaram.

Além dos resultados descritos acima, cabe assinalar o quanto os modelos propostos para a verificação das hipóteses colaboraram para o entendimento da proporção de votos dada a Geraldo Alckmin nas três eleições. O $\operatorname{Radj}^{2}$ (R ajustado ao quadrado) é o índice responsável por medir o ajustamento do modelo estatístico em relação aos valores observados na amostra. De acordo com a tabela 3, os Radj $^{2}$ dos modelos relativos a 2002, 2010 e 2014 são, respectivamente, 0,11, 0,11 e 0,18. Isso significa dizer que, especificamente, as variáveis independentes contidas no modelo de 2002 e 2010 explicam apenas $11 \%$ da variação da proporção de votos dada ao governador. Já em 2014, essa porcentagem é de $18 \%$.

Os modelos estatísticos mostraram, portanto, não ser suficientes para explicar o êxito eleitoral de Geraldo Alckmin; com isso, alertam para o fato de que outros fatores, além dos indicadores socioeconômicos, devem ser incluídos para a compreensão da proporção de votos dada ao tucano eleito em São Paulo. Buscar-se-á a seguir sinalizar três aspectos que podem estar relacionados às vitórias de Alckmin e do PSDB.

$\mathrm{O}$ primeiro deles corresponde às alianças firmadas pelo PSDB e por Geraldo Alckmin em São Paulo. A capacidade de um candidato e de seu partido de agregar aliados certamente fortalece a candidatura proposta em termos políticos, isto é, na disputa com adversários, e também em termos eleitorais, tendo em vista a possibilidade de uma transferência de votos dos eleitores de um partido ou político para outro. Nesse sentido, acredita-se que Alckmin é beneficiado no estado por reunir em torno de si aliados das mais variadas legendas partidárias.

A fim de descrever o ambiente eleitoral no qual as alianças tucanas foram firmadas, foi feita a reconstrução do contexto de cada eleição a partir da consulta a material de imprensa, principalmente aos acervos disponibilizados pelos jornais Folha de S. Paulo e $O$ Estado de S. Paulo. Outras fontes também foram consultadas, como jornais locais e artigos de revistas avulsas. 
A imagem de Alckmin perante o eleitorado é outro aspecto que compõe a análise de suas vitórias. Por meio de matérias publicadas na imprensa e mediante informações de pessoas próximas sobre sua personalidade e estilo de trabalho, foi possível traçar um perfil do político Alckmin e perceber que seu tom conciliador e seu jeito atencioso o ajuda a cativar aliados e votantes.

Ao passo que o PSDB e seus candidatos avançam sobre o eleitorado paulista, o Partido dos Trabalhadores, seu principal adversário, recua - e esse foi outro aspecto analisado. Acredita-se que o sucesso eleitoral dos tucanos em SP não decorre somente do mérito próprio, mas também tem como causa o desprestígio do PT no estado, diante do seu envolvimento, principalmente nos últimos anos, em escândalos de corrupção e do lançamento de candidaturas inexpressivas.

Ressalta-se que os três fatores apresentados bem como a relação entre voto e indicadores socioeconômicos não se excluem como possíveis motivos para o sucesso de Alckmin. Na realidade, eles podem ser incluídos em conjunto numa explicação contextual empiricamente mais rica desse sucesso. É tendo isso em vista que a pesquisa será desenvolvida a seguir. 


\section{CAPÍTULO 2 - O PSDB PAULISTA: A HEGEMONIA TUCANA NA TERRA DA GAROA}

\subsection{A criação do Partido da Social Democracia Brasileira e o reduto do partido em São Paulo}

A forte presença paulista na direção do PMDB, antigo MDB no período da ditadura, fez com que São Paulo, o centro econômico do país, politicamente minoritário desde a Revolução de 1930, ganhasse preponderância em Brasília. Até a Segunda Guerra Mundial o Rio de Janeiro era o centro político, econômico e cultural do Brasil. Ao contrário do que poderia supor um marxista ortodoxo, o poder econômico de São Paulo durante muito tempo não correspondeu ao seu poder político. Foi no início dos anos 1980 que a elite paulista converteu seu capital econômico em capital político, como diria Pierre Bourdieu, sendo São Paulo visto a partir daí como o estado modernizador da política nacional.

Criado em junho de 1988, em meio à Assembleia Constituinte, o Partido da Social Democracia Brasileira (PSDB) foi fundado, sobretudo, por dissidentes do Partido do Movimento Democrático Brasileiro (PMDB). Dos 559 constituintes, 44 se juntaram na formação do novo partido; desses, 37 estavam antes no PMDB. De um total de 116 fundadores, segundo a ata da reunião de fundação, 35 eram paulistas; nenhum outro estado da federação tinha tantos representantes.

O discurso oficial da separação abarcou a existência, em tese, de divisões programáticas entre membros do partido. Políticos peemedebistas notórios à época como os senadores Fernando Henrique Cardoso (SP), Mário Covas (SP) e José Richa (PR), bem como os deputados federais José Serra (SP), Geraldo Alckmin (SP), Pimenta da Veiga (MG) e Euclides Scalco (PR), e também o ex-governador de São Paulo André Franco Montoro, diziam-se descontentes com os rumos tomados pelo PMDB durante a Assembleia Constituinte de 1988, especialmente quando uma ala de centro-direita do partido formou o denominado "Centrão", articulação que era contrária à aprovação de medidas progressistas na Constituição.

Entretanto, na verdade, sabe-se que a dissidência se deu também (ou tão somente) pelo anseio de alguns integrantes por mais poder dentro do partido, de modo que 
vários dos separatistas mudaram de legenda por falta de espaço político, insatisfeitos com o diálogo político com o então Presidente da República, José Sarney, ou atritados com o governador de Minas Gerais, Newton Cardoso, ou com o governador de São Paulo, Orestes Quércia. Pode-se lembrar, como exemplo, o paulista e um dos principais futuros fundadores do PSDB, Mário Covas, que desistiu, após pressões do PMDB, de ser o candidato a vice na chapa de Franco Montoro para o governo de SP em 1982, cedendo seu lugar a Quércia. Partidários de Covas alegaram na época que acordos não teriam sido cumpridos. Ou em 1986, quando Covas mais uma vez foi preterido pelo partido, agora para encabeçar a disputa pelo governo paulista, em benefício de Quércia ${ }^{15}$.

$\mathrm{O}$ fato é que as divergências entre integrantes do PMDB e Quércia fizeram com que dois senadores e dez deputados, todos eleitos por São Paulo, deixassem o partido. Ao mesmo tempo, adversários de Newton Cardoso contribuíram para o novo partido com sete deputados federais da bancada peemedebista mineira. Além de integrantes do PMDB, quatro políticos do PFL e três mulheres, cada uma do PDT, PTB e PSB, abandonaram seus partidos para dar início ao PSDB.

A justificativa do descontentamento com o "Centrão" para a formação da nova legenda fica fragilizada na medida em que alguns políticos que se alinharam em muitas votações com a ala de centro-direita se filiaram ao PSDB. O ex-deputado Silvio Abreu, eleito pelo PMDB mineiro, é um exemplo disso. Ele assinou a sua ficha de inscrição no novo partido logo após se estranhar com o governador de Minas Gerais por começar a receber favores do ex-ministro Aníbal Teixeira para o município de Juiz de Fora, sua base eleitoral ${ }^{16}$. Além disso, tem-se notícia de que alguns políticos ameaçaram não contribuir com seus nomes para o novo partido quando viram o nome de outros na lista.

As adversidades e divergências que, segundo o então deputado constituinte Geraldo Alckmin, estariam longe de se instalar no novo partido, o qual seria "maior que as pessoas que o integram"17, estavam presentes desde sua formação, e só o tempo diria se os interesses partidários, tão afirmados, chegariam a ser superados por questões provincianas e regionais. Mais tarde, após as eleições de 2002, o PSDB paulista veria sua hegemonia

\footnotetext{
${ }^{15}$ Em janeiro de 1986, Covas, mesmo insatisfeito com a perda de espaço que seus aliados dentro do partido tinham sofrido na escolha do Diretório Regional, que contava com mais membros partidários de Quércia, chegou a dizer que não o incomodava a corrente quercista, pois julgava "(...) a escolha do candidato ao governo estadual uma questão diferenciada da eleição da Executiva Regional do PMDB, porque o partido é permanente". Em Folha de S. Paulo de 27 de janeiro de 1986.

${ }^{16}$ Folha de S. Paulo, sábado, 25 de junho de 1988, Primeiro Caderno, Política, p. A 5.

${ }^{17}$ Idem.
} 
questionada por outro núcleo psdebista formado, entre outros, por Aécio Neves (MG) e Tasso Jereissati (CE), os quais, com a saída do PSDB da presidência da República, afirmavam que estava na hora de "arejar o partido".

A nova legenda, que também tinha por opção de nome chamar-se Partido Democrático Popular (PDP), formou a terceira bancada no plenário do Congresso constituinte, atrás de PMDB e PFL, sendo sua base constituída especialmente por parlamentares das regiões Sudeste e Sul.

Logo após a criação do partido vieram as eleições de 1989. Mário Covas, primeiro presidente do PSDB, foi lançado pelo partido como candidato à Presidência da República, ficando apenas em quarto lugar. José Serra, no mesmo ano, teve sua candidatura lançada para prefeito da cidade de São Paulo e, nessa eleição, já foi possível verificar a transferência de votos do candidato do PMDB, João Oswaldo Leiva, para Serra, devido à queda de votos do primeiro e ao aumento na mesma proporção dos votos no segundo. Ainda que isso não tenha sido suficiente para colocar o candidato tucano na frente, serviu para acirrar os ânimos na reta final das eleições daquele ano. Um ano antes, no entanto, nas eleições municipais, o partido, que ainda estava em fase de constituição, conseguiu eleger 18 prefeitos, e já nas eleições de 1992 esse número subiu para 293.

De início, o programa partidário psdebista, apoiando o parlamentarismo, pautava o estabelecimento da justiça social e da distribuição de renda para o desenvolvimento do país, uma economia de mercado regulada pelo Estado, bem como o equilíbrio entre as liberdades individuais e a efetivação de políticas sociais de combate às desigualdades. Com essa agenda política, qualificada na época de centro-esquerda, o PSDB foi visto como uma promessa para o cenário político brasileiro que estava se formando, tendo em vista que, para muitos, reunia algumas cabeças que estariam dispostas historicamente a contribuir com o regime democrático.

Atualmente, o PSDB pode ser considerado um partido com visibilidade nacional, devido ao aumento nos últimos anos de sua representatividade nos âmbitos federal, estadual e municipal, e ao consequente aumento da sua inserção no contexto político brasileiro. Embora seus candidatos não ganhem uma eleição para Presidente da República desde 1998, ano da reeleição de Fernando Henrique Cardoso, o partido, nas quatro últimas eleições para o cargo, vem aumentando o número de eleitores, indo sempre ao segundo turno. 
Na Câmara Federal o partido é hoje o terceiro colocado no número de cadeiras, tendo 54 deputados. Além disso, ele está no comando de 702 prefeituras, ficando atrás apenas do PMDB, que tem 1.031, e hoje governa cinco estados, os quais somam mais de $1 / 3$ do total da população do país, o que corresponde a mais de 70 milhões de habitantes. $\mathrm{O}$ estado com maior peso nesse cálculo é São Paulo. Nele, o PSDB nas eleições de 2014 conquistou o sexto mandato consecutivo. A alternância de governo não é vista no poder executivo estadual paulista há 20 anos.

Para alguns - aqueles adeptos de uma vertente sociológica associada à teoria do desenvolvimento político -, a instabilidade eleitoral corresponderia, não à vitalidade do sistema político, como aponta Pasquino (2005), mas sim à baixa efetividade do governo e à fragilidade partidária, direcionando até para a debilidade da democracia. Para esses, a renovação de poder seria sinônimo da baixa institucionalização partidária, em que os partidos não conseguem exercer sua função de mobilizar clivagens sociais e formar identidades políticas. A estabilidade do comportamento eleitoral é vista como positiva porque, caso a competição permaneça em um nível mínimo, os partidos manteriam fortes vínculos sociais com os indivíduos. Na ausência dela, muitas vezes fala-se em crise, e a culpa recai, para alguns, nos partidos, por sua descaracterização, para outros, nos eleitores, por sua alienação e irracionalidade. Contrariamente, há também os que veem a instabilidade como positiva, porquanto a escolha eleitoral se dá de forma racional $^{18}$, baseada em um cálculo utilitário.

Como se vê, certamente essas questões propiciam um longo e animado debate, dentro do qual existem infinitas divergências entre os autores. No entanto, entende-se, considerando os fins deste estudo, que valorizar uma abordagem em detrimento de outra é ter uma visão simplória da dinâmica político-eleitoral e resulta na marginalização de aspectos que juntos constroem o que realmente é a política.

Concordando-se com Bartolini e Mair (1990), ao mesmo tempo que, em longo prazo, a estabilidade eleitoral contribui para a consolidação do regime democrático, certo grau de instabilidade se faz necessário para que haja responsividade e accountability dos governos perante os eleitores. Assim, qualificar uma ou outra de boa ou má é dar voltas, contrárias, em torno de um mesmo ponto e, com isso, perder de vista interpretações alternativas que possam agregar mais em comparação àquelas clássicas.

\footnotetext{
${ }^{18}$ Entende-se por racionalidade a capacidade de escolha estruturada de maneira coerente e ordenada.
} 
É nesse sentido que, conforme aponta Paulo Sergio Peres (2013), a renovação ou não de quem está no poder deve ser vista como um resultado das dinâmicas do mercado eleitoral, onde as normas vigentes e os recursos disponíveis afetam a "oferta" e a "demanda", e não como algo associado a uma crise dos partidos ou do sistema representativo, ou ainda, com a suposta irracionalidade de quem vota.

Para Peres, entendendo-se o sistema partidário como o constituidor do mercado eleitoral, os resultados eleitorais que beneficiam o governo ou os seus concorrentes devem ser contextualizados, levando-se em consideração quem está na competição, quem realmente é competitivo e por isso se torna uma candidatura viável aos olhos dos votantes e, por fim, quais são as regras e o ambiente político-eleitoral no qual se inserem candidatos e eleitores.

É sabido que os votantes respondem às opções que lhes são dadas em uma eleição, as quais foram anteriormente escolhidas pelos grupos políticos, tendo em vista diferentes nomes e fatores, sem contar as regras que cada partido possui para a seleção, bem como a influência nesse sentido das lideranças. Segundo Peres (2013, p. 38), “(...) tanto a estabilidade (...) como a instabilidade (...) poderiam ser interpretadas no contexto da competição eleitoral e da escolha estratégica dos eleitores vis-à-vis a maior ou menor coordenação das elites políticas (...)”. Na mesma linha de pensamento, Zygmunt Bauman aponta que "a liberdade de opção individual" opera segundo uma agenda de alternativas de fato disponíveis, de forma que "toda opção implica escolher uma coisa dentre outras e raramente o conjunto de coisas a escolher depende daquele que escolhe" (BAUMAN, 2000, p. 79).

Portanto, deve-se compreender tanto uma eleição quanto a renovação de um mandato a partir de aspectos que façam parte daquilo que está presente na disputa, sejam as rivalidades ou as alianças entre políticos e partidos, a abordagem da mídia acerca dos candidatos, a campanha eleitoral desses, a conjuntura social e econômica ou os ânimos dos eleitores. Torna-se improdutivo explicar o sucesso ou o fracasso eleitoral apenas por meio de conjecturas baseadas no dever-ser que pregam muitas das teorias políticas tradicionais, salientando, contudo, a contribuição que estas deram ao seu tempo e para o desenvolvimento de novas ideias. É baseado nesse pensamento que serão descritas e interpretadas as eleições tucanas para o governo de São Paulo. 


\subsection{O contexto político de São Paulo na década de 90: a pavimentação por Mário Covas do caminho de Alckmin}

O nome de Mário Covas foi novamente escolhido pelo PSDB para participar das eleições, desta feita para governador de São Paulo, em 1990. As pesquisas de boca de urna apontavam na véspera da eleição o candidato tucano em terceiro lugar, à frente do concorrente petista Plínio Sampaio e atrás de Paulo Maluf (Partido Democrático Social PSD) e de Luís Antônio Fleury Filho (PMDB), os quais, em novembro do mesmo ano, disputariam o segundo turno, confirmando que ainda não seria daquela vez que o PSDB conquistaria o governo paulista. Segundo a manchete do jornal Folha de S. Paulo do dia 26 de novembro de 1990, um dia após o segundo turno, a "vitória no interior [faria] de Fleury virtual governador de São Paulo”.

$\mathrm{Na}$ época, o resultado das apurações não saía tão rápido como hoje. Com a vitória em 1990 do PMDB, foi a terceira vez consecutiva que esse partido ganhou as eleições para o governo de São Paulo e, segundo as previsões feitas pelo Datafolha, pela segunda vez graças aos eleitores interioranos. Essa característica do eleitorado de Fleury, apontada pelo instituto de pesquisa, deve ser destacada, tendo em vista que, diante da maleabilidade do cenário político entre períodos eleitorais - o que inclui a entrada e a saída de candidatos e partidos da competição bem como a perda de força eleitoral por alguns e ganho por outros -, acredita-se que o PSDB, a partir de 1994, atraiu para si pelo menos parte dos eleitores que antes pertenciam, com certa vantagem, ao PMDB. A importância eleitoral do interior de São Paulo para as consecutivas vitórias tucanas, especialmente as de Geraldo Alckmin, será discutida em momento oportuno mais adiante.

Enquanto a vitória de Fleury era associada aos eleitores interioranos, seu rival, Paulo Maluf, obteria vantagem na Grande São Paulo, tendo como eleitor típico o cidadão de baixa escolaridade, porém com nível de renda médio ${ }^{19}$. É plausível que essa vantagem malufista na região metropolitana esteja associada à liderança que o candidato exerceu na região, porquanto exercera o cargo de prefeito de São Paulo por duas vezes: uma por indicação, no final da década de 60, e outra, mais tarde, por eleição em 1992.

${ }^{19}$ O perfil do típico eleitor malufista foi traçado pelo sociólogo Antônio Flávio Pierucci mediante a realização de 170 entrevistas feitas em 1986. Na época, Pierucci calculou que o eleitorado típico de Paulo Maluf com baixa escolaridade e renda média equivalia ao seu eleitorado permanente, o qual seria de $15 \%$ a $20 \%$ dos paulistas. Mais detalhes do estudo podem ser encontrados no jornal Folha de S. Paulo de 4 de outubro de 1990 < http://acervo.folha.uol.com.br/fsp/1990/10/04/125/> 
Cabe ressaltar ainda que a preferência na Grande São Paulo por Maluf estava repetindo a tendência do eleitorado paulistano de optar por candidatos de oposição ao governo do estado, conforme ocorreu nas eleições municipais de 1985 e 1988 com a escolha, respectivamente, de Jânio Quadros e Luiza Erundina, e nas eleições estaduais de 1986 com a vitória na capital de Antônio Ermírio de Moraes (PTB). Essa tendência do eleitorado paulistano observada nas eleições da década de 80 evidencia-se também nas últimas eleições municipais com a vitória de Fernando Haddad, do Partido dos Trabalhadores (PT), para prefeito de São Paulo, ou até mesmo com a vitória de Marta Suplicy (PT) em 2000, ou de Gilberto Kassab (Democratas) em 2008, para o mesmo cargo.

A conquista de três mandatos pelos petistas para a prefeitura de São Paulo, a despeito de não conseguirem se inserir no governo estadual, faz com que a imprensa afirme existir um "cinturão vermelho" que engloba a cidade e os municípios que a rodeiam, de modo que os candidatos tucanos ao governo estadual teriam suas votações diminuídas nessa região em comparação, por exemplo, com o interior do estado. Nesse sentido, com a saída de Paulo Maluf das competições eleitorais no estado, a preferência política do paulistano passou do PDS - mais tarde PPB -, partido de Maluf, para o PT. Como este e os demais partidos que disputam o governo estadual se relacionam às sucessivas vitórias do PSDB será um tema discutido posteriormente.

Embora em 1990 o PSDB tenha ficado em terceiro lugar com a candidatura de Covas, esse foi um ótimo resultado para uma agremiação que havia sido criada há pouco mais de dois anos. O PSDB não contava com o apoio formal de nenhum partido, e na primeira disputa para o Poder Executivo estadual desbancou o PT, criado há dez anos, obtendo no primeiro turno uma diferença de menos de 2 milhões de votos para o então segundo colocado PMDB, que tinha na coligação o PFL como principal força. Fleury Filho, ao vencer o segundo turno contra Maluf, substituiu seu padrinho político, Orestes Quércia, no governo de São Paulo. No entanto, por protagonizar atritos entre filiados, o partido não conseguiria manter o governo no pleito de 1994.

Fleury assumiu o governo em meio a denúncias contra a gestão do exgovernador e teve de lidar com dívidas e obras paralisadas. O "caso Banespa" tornou-se um escândalo em dois momentos do governo Quércia e serviu para enfraquecer o PMDB 
em São Paulo ${ }^{20}$. Às vésperas da eleição de 1990, o governador foi apontado como o responsável por mais um desmando no então maior banco estadual do Brasil, o que resultara na retirada pelo governo de mais de 670 milhões de dólares em empréstimos especiais denominados de "antecipação de receita orçamentária - ARO". Logo, os problemas superaram a afeição entre padrinho e afilhado, e Quércia e Fleury tornaram-se adversários. O resultado foi a renúncia do primeiro da presidência do PMDB em 1993, acusando o ex-pupilo de traição.

No entanto, os excessos em relação ao Banespa continuaram no governo Fleury, e no final de seu mandato a dívida do estado com o banco era de aproximadamente 10 bilhões de dólares. Apesar dos investimentos sociais feitos por Fleury em São Paulo, como o programa habitacional que viabilizou a construção de 250 mil moradias, os pontos negativos de sua gestão pesaram mais para os paulistas e para seus apoiadores, prejudicando a tentativa de reeleição do PMDB com Barros Munhoz, que em 1994 já não tinha o apoio do PFL e de outros partidos que fizeram parte da coligação em 1990.

$\mathrm{Na}$ sua segunda tentativa para se eleger como governador de SP, Covas concentrou sua campanha em cinco cidades do Vale do Paraíba - São José dos Campos, Taubaté, Lorena, Cruzeiro e São Sebastião -, que foram escolhidas de acordo com critérios geográficos e importância política, segundo o então coordenador da campanha ${ }^{21}$. O PSDB realmente possuía fortes razões para definir a região como prioritária. São José dos Campos tinha o maior colégio eleitoral do Vale e as cidades de Taubaté, Cruzeiro e Lorena tinham prefeitos tucanos, os quais poderiam intermediar o contato de Covas com a população e auxiliar no seu convencimento. Além disso, o Vale do Paraíba era a principal base eleitoral do vice de Mário Covas, Geraldo Alckmin, natural de Pindamonhangaba, cidade na qual foi vereador e prefeito. Para exemplificar, em 2002, quando candidato ao governo de SP, Alckmin, mesmo com o pior índice de aprovação, tinha sua melhor avaliação entre os eleitores interioranos ${ }^{22}$.

Em 1994, Mário Covas venceu em segundo turno - com o apoio do terceiro colocado José Dirceu e de seu partido, o PT - Francisco Rossi, do Partido Democrático

\footnotetext{
${ }^{20}$ Fleury venceu a eleição de 1990 para governador de SP, mas com dificuldade, certamente em decorrência dos escândalos ocorridos principalmente no final do mandato de seu antecessor. $\mathrm{O}$ primeiro turno foi marcado pela vitória de Paulo Maluf (PDS) com 34,28\% e Fleury em segundo lugar com 22,20\% dos votos válidos. Uma das hipóteses para a virada do candidato do PMDB é a predileção que o mesmo possuía entre os eleitores do interior do estado, conforme já apontado.

${ }^{21}$ Folha de S. Paulo, Folha Vale, 6 de Junho de 1994.

${ }^{22}$ Folha de S. Paulo, 19 de agosto de 2002, Folha Eleições 2002.
} 
Trabalhista (PDT). Radialista e tendo como base de sustentação o segmento evangélico, Rossi tinha sido por duas vezes prefeito de Osasco e, embora houvesse exercido o cargo de secretário de educação e turismo na gestão de Maluf no governo de SP, não recebeu o apoio dele para a sua candidatura. Ao contrário, Maluf, que era na época o prefeito de São Paulo, formalizou, no segundo turno, o apoio do seu partido, o Partido Progressista Reformador (PPR), ao candidato do PSDB, após ter se coligado no primeiro turno com o PP, apoiando Luiz Antonio Medeiros, que ficou em quinto lugar.

Na ocasião, em reunião com Fernando Henrique Cardoso, presidente eleito, Maluf, que foi adversário de Covas na eleição de 1990, afirmou que "São Paulo [precisava] de um governador alinhado com o novo presidente" ${ }^{23}$. Além do apoio das duas maiores forças políticas do estado de São Paulo, o PFL e o PPR de Maluf, Covas e o PSDB também tinham o suporte de parte significativa das prefeituras de alguns dos redutos peemedebistas, entre eles o de São José do Rio Preto, cidade que contava com cerca de 1 milhão de eleitores. Segundo um dos coordenadores da campanha tucana, a estratégia do partido para garantir votos de última hora foi convocar as lideranças regionais dos partidos apoiadores e orientá-los a conversar com os eleitores ${ }^{24}$.

Certamente o maior tempo de propaganda eleitoral na TV e no rádio também contribuiu para o crescimento da visibilidade tucana nesse ano. Em linhas gerais, o cálculo da divisão do horário eleitoral gratuito beneficia os partidos com maior representação na Câmara dos Deputados, considerando o resultado da eleição imediatamente anterior. Em 1994 o PSDB conquistou o segundo maior tempo de propaganda eleitoral gratuita graças a sua aliança com o PFL. Ambos os partidos somaram nas eleições de 1990 o total de 191 deputados, o que representava mais de $37 \%$ da composição total da Câmara.

Apenas no pleito de 1998 o PSDB não foi para o segundo turno possuindo a maior porcentagem de votos, colocação que foi ocupada, na época, pelo Partido Progressista Brasileiro (PPB), com Paulo Maluf, partido este que possuía até o momento uma força significativa na política paulista graças à liderança de seu candidato. A deputada federal Marta Suplicy foi a candidata lançada pelo PT; mesmo tendo como principal cabo eleitoral o marido Eduardo Suplicy, reeleito para o Senado Federal, fez uma campanha que contava com poucos recursos financeiros, ficando em terceiro lugar na disputa e apoiando posteriormente Covas no segundo turno.

\footnotetext{
${ }^{23}$ Folha de S. Paulo, Primeiro Caderno, segunda-feira, 31 de outubro de 1994, p. 1.

${ }^{24}$ Folha de S. Paulo, Folha Norte, terça-feira, 15 de novembro de 1994, p. 1.
} 
Nessa eleição, o PFL e o quarto colocado no primeiro turno pelo PDT, Francisco Rossi, estavam do lado de seu principal rival ${ }^{25}$. No âmbito nacional, o PDT de Rossi apoiava a candidatura do petista Luiz Inácio Lula da Silva, tendo Leonel Brizola como candidato a vice-presidente. PTB, PSD e PV eram os partidos aos quais os tucanos estavam coligados e, em certa medida, refaziam a aliança de centro-direita que o PSDB possuía com o PFL na eleição anterior. Alckmin, novamente candidato a vice-governador, antes do pleito procurou Covas para dizer que ele ficasse à vontade para montar a chapa com um vice do PFL, o que manteria o partido na coligação. Ouviu a indagação: "Está com medo de perder a eleição? Não tem discussão, é você mesmo"26.

O foco do PSDB no interior do estado também ocorreu em 1998 e foi imprescindível para a reeleição de Covas em outubro, em prejuízo de seu rival Paulo Maluf (PPB), que, em setembro daquele ano, ainda mantinha a liderança na disputa. Sabendo que enfrentaria uma campanha árdua e difícil, Covas se licenciou do governo para se dedicar somente à reeleição, e Alckmin o assumiu o governo estadual pela primeira vez. Na época, o governo psdebista encarou sérias dificuldades em relação ao eleitorado por conta da política de "arrocho" que havia implementado no primeiro mandato, resultando em corte de despesas e alta taxa de desemprego. Nos três primeiros anos de governo, Covas gastou mais com a dívida de São Paulo, deixada pelos mandatos do PMDB, do que com políticas de saúde ou segurança, fato que era mostrado como forma de ataque pelo seu concorrente Maluf no horário eleitoral na $\mathrm{TV}^{27}$.

A tabela 4, abaixo, mostra que os resultados do candidato tucano à reeleição nos municípios do Vale do Paraíba foram bem melhores em 1994 do que em 1998; de uma eleição para a outra os votos em todos os municípios dessa região caíram pela metade no primeiro turno. Covas, que em sua campanha afirmou que a tarefa de seu primeiro governo tinha sido "colocar a casa em ordem", acabou indo, com dificuldade, ao segundo turno e ganhou com uma diferença menor que 2 milhões de votos em relação a Maluf, que, tendo sido governador de São Paulo por indicação do governo Geisel ${ }^{28}$, já tinha perdido, para o

\footnotetext{
${ }^{26}$ Folha de S. Paulo, Primeiro Caderno, 15 de março de 2006, p. 8.

${ }^{27}$ Ver horário eleitoral em https://www.youtube.com/watch?v=V23Cgj6Po-8.

${ }^{28}$ Maluf venceu, em 1978, a convenção da Arena, partido que, no comando, indicava quem seriam os governadores. Em seu mandato, que durou até 1982, realizou uma administração controversa. Criou a Paulipetro, empresa estatal que seria responsável por procurar e extrair petróleo e gás natural da bacia do rio Paraná. Na época, foram gastos cerca de 500 milhões de dólares em perfurações, sem nenhum resultado significativo.
} 
mesmo cargo, as eleições diretas de 1986 e 1990. Mesmo com uma disputa bastante acirrada, à época, a votação obtida por Covas - mais de 9 milhões de votos - foi a maior em números absolutos já conquistada por um governador eleito no país.

Tabela 4 - Porcentagens de votos válidos para o governador eleito em São Paulo em 1998, Mário Covas (PSDB), nos municípios do Vale do Paraíba, referentes ao 1 o turno

\begin{tabular}{|c|c|c|c|c|}
\hline Município & $\begin{array}{c}\text { Colocação } \\
1994\end{array}$ & $\begin{array}{c}\text { Porcentagem Votos } \\
\text { Válidos } 1994\end{array}$ & $\begin{array}{c}\text { Colocação } \\
1998\end{array}$ & $\begin{array}{c}\text { Porcentagem Votos } \\
\text { Válidos } 1998 \\
\end{array}$ \\
\hline Lagoinha & $1^{\mathrm{o}}$ & $81,33 \%$ & $122^{\circ}$ & $32,49 \%$ \\
\hline Pindamonhangaba & $5^{\circ}$ & $74,48 \%$ & $58^{\circ}$ & $39,90 \%$ \\
\hline Roseira & $6^{\circ}$ & $73,96 \%$ & $163^{\circ}$ & $29,56 \%$ \\
\hline São José do Barreiro & $11^{\circ}$ & $72,10 \%$ & $133^{\circ}$ & $31,44 \%$ \\
\hline São Luiz do Paraitinga & $19^{\circ}$ & $70,33 \%$ & $346^{\circ}$ & $21,61 \%$ \\
\hline Aparecida & $20^{\circ}$ & $70,27 \%$ & $300^{\circ}$ & $23,09 \%$ \\
\hline Areias & $21^{\circ}$ & $70,11 \%$ & $84^{\circ}$ & $36,23 \%$ \\
\hline Queluz & $25^{\circ}$ & $69,37 \%$ & $421^{\circ}$ & $19,32 \%$ \\
\hline Bananal & $26^{\circ}$ & $69,21 \%$ & $56^{\circ}$ & $40,04 \%$ \\
\hline Redenção da Serra & $38^{\circ}$ & $66,98 \%$ & $248^{\circ}$ & $25,10 \%$ \\
\hline Arapeí & $46^{\circ}$ & $66,20 \%$ & $83^{\circ}$ & $36,54 \%$ \\
\hline Monteiro Lobato & $51^{\circ}$ & $65,90 \%$ & $206^{\circ}$ & $27,03 \%$ \\
\hline Guaratinguetá & $52^{\circ}$ & $65,78 \%$ & $130^{\circ}$ & $31,74 \%$ \\
\hline Cunha & $78^{\circ}$ & $63,72 \%$ & $331^{\circ}$ & $22,09 \%$ \\
\hline Taubaté & $84^{\circ}$ & $63,43 \%$ & $192^{\circ}$ & $27,55 \%$ \\
\hline Potim & $95^{\circ}$ & $63,13 \%$ & $267^{\circ}$ & $24,52 \%$ \\
\hline Natividade da Serra & $97^{\circ}$ & $62,97 \%$ & $535^{\circ}$ & $16,10 \%$ \\
\hline Tremembé & $106^{\circ}$ & $62,30 \%$ & $343^{\circ}$ & $21,81 \%$ \\
\hline Silveiras & $117^{\circ}$ & $61,92 \%$ & $280^{\circ}$ & $23,83 \%$ \\
\hline Igaratá & $130^{\circ}$ & $61,22 \%$ & $621^{\circ}$ & $12,01 \%$ \\
\hline Lavrinhas & $170^{\circ}$ & $59,82 \%$ & $43^{\circ}$ & $41,98 \%$ \\
\hline Caraguatatuba & $177^{\circ}$ & $59,33 \%$ & $91^{\circ}$ & $35,16 \%$ \\
\hline Ubatuba & $188^{\circ}$ & $58,96 \%$ & $235^{\circ}$ & $25,67 \%$ \\
\hline Piquete & $192^{\circ}$ & $58,87 \%$ & $467^{\circ}$ & $17,83 \%$ \\
\hline Cruzeiro & $194^{\circ}$ & $58,85 \%$ & $426^{\circ}$ & $19,05 \%$ \\
\hline São José dos Campos & $210^{\circ}$ & $58,10 \%$ & $316^{\circ}$ & $22,52 \%$ \\
\hline Lorena & $218^{\circ}$ & $57,80 \%$ & $194^{\circ}$ & $27,52 \%$ \\
\hline Paraibuna & $219^{\circ}$ & $57,67 \%$ & $478^{\circ}$ & $17,57 \%$ \\
\hline Jambeiro & $261^{\circ}$ & $56,29 \%$ & $185^{\circ}$ & $28,38 \%$ \\
\hline Atibaia & $269^{\circ}$ & $56,13 \%$ & $214^{\circ}$ & $26,83 \%$ \\
\hline Nazaré Paulista & $282^{\circ}$ & $55,91 \%$ & $432^{\circ}$ & $18,96 \%$ \\
\hline Salesópolis & $305^{\circ}$ & $55,07 \%$ & $452^{\circ}$ & $18,31 \%$ \\
\hline Campos do Jordão & $321^{\circ}$ & $54,62 \%$ & $405^{\circ}$ & $19,59 \%$ \\
\hline Santa Branca & $369^{\circ}$ & $52,97 \%$ & $489^{\circ}$ & $17,36 \%$ \\
\hline São Sebastião & $397^{\circ}$ & $52,17 \%$ & $226^{\circ}$ & $26,06 \%$ \\
\hline
\end{tabular}




\begin{tabular}{c|cc|cc} 
Jacareí & $407^{\circ}$ & $51,75 \%$ & $471^{\circ}$ & $17,69 \%$ \\
Guararema & $425^{\circ}$ & $50,83 \%$ & $485^{\circ}$ & $17,45 \%$ \\
Caçapava & $475^{\circ}$ & $48,85 \%$ & $464^{\circ}$ & $17,94 \%$ \\
Cachoeira Paulista & $469^{\circ}$ & $40,70 \%$ & $227^{\circ}$ & $26,05 \%$ \\
Canas* & & & $66^{\circ}$ & $38,77 \%$ \\
\hline
\end{tabular}

Fonte: elaboração da autora a partir de dados do TSE.

*Na base do ano de 1994 não havia dados para o município de Canas.

Após o seu envolvimento em denúncias de corrupção que estouraram no início dos anos 2000, o PPB e Maluf entraram em decadência ${ }^{29}$ com a desarticulação das suas bases municipais de apoio $^{30}$ (LIMONGI; MESQUITA, 2011) e a perda de suas principais bandeiras, abrindo espaço para uma inserção maior do PT na arena política estadual bem como na capital paulista. Nas três eleições estaduais seguintes, candidatos do PT ficaram na segunda colocação, todavia a diferença de votos para o vitorioso PSDB chegou a ultrapassar os cinco milhões de votos na eleição de 2006. Assim como o PPB, o PMDB também tinha perdido espaço político em São Paulo desde as eleições de 1994. Com a decadência peemedebista no estado, o PSDB sobreveio como a força política substituta. E o protagonismo do PPB passou, pouco a pouco, para o PT, embora nenhum candidato petista tenha assumido o papel que a liderança de Maluf chegou a exercer.

No decorrer das eleições, o cenário político paulista foi se modificando e o peso dos partidos e candidatos foi se rearranjando em decorrência de diversas circunstâncias, entre elas o envolvimento em escândalos e desgaste de uns e a boa estratégia de outros para se colocarem como alternativas viáveis ao eleitorado. Com a nova conjuntura política os partidos de centro-direita como PPB, PMDB e PTB perderam parte significativa do poder que detinham e enfraqueceram-se os "caciques", tais como o próprio Maluf e Orestes Quércia em São Paulo, Esperidião Amin em Santa Catarina, Itamar Franco e Newton Cardoso em Minas Gerais, e Leonel Brizola no Rio de Janeiro. Abriu-se, então,

\footnotetext{
${ }^{29}$ A queda de Paulo Maluf como liderança política se iniciou quando ele foi prefeito de São Paulo entre 1993 e 1996 e teve seu nome envolvido em diversas acusações de irregularidades administrativas. O problema piorou quando Celso Pitta, seu afilhado político e secretário de finanças no seu governo, substituiu-o no cargo e fez uma administração desastrosa. Pitta, que nunca havia disputado uma eleição, teve como marca de seu mandato a precariedade financeira, que estava relacionada ao pagamento de muitas obras firmadas no último ano da gestão Maluf (MARQUES, 2003). Tendo sido implicado em diversas denúncias de corrupção, Pitta chegou a perder o cargo por decisão da justiça, recuperando-o posteriormente.

${ }^{30}$ Embora Maluf mantivesse o apoio de sua principal base eleitoral constituída por trabalhadores autônomos e profissionais liberais, essa se estreitara em termos relativos desde a década de 90. Além disso, os trabalhadores assalariados com renda mais elevada certamente deixaram de apoiá-lo durante a gestão Pitta, o que também deve ter ocorrido com parcela dos eleitores de baixa escolaridade e renda.
} 
espaço para o crescimento do PSDB e do PT, principalmente, bem como para a ascensão do PFL, especialmente em São Paulo.

Nesse contexto a liderança política de Covas em São Paulo era evidente; o PSDB no estado e nacionalmente certamente cresceria com ele e por causa dele. Em entrevista à Folha de S. Paulo em janeiro de $2001^{31}$, Antônio Carlos Magalhães chegou a dizer que, apesar das desavenças políticas ${ }^{32}$, considerava-o naquele momento a maior figura do PSDB. O governo e a liderança de Covas, no entanto, estavam com os dias contados. Em janeiro de 2001, Covas foi internado no Instituto do Coração em São Paulo e sua agenda, que incluía viagens ao interior do estado para a entrega de moradias, foi cumprida por seu vice, Geraldo Alckmin, que recebeu por onde passou imagens de santos, medalhas e cartas destinadas ao governador ${ }^{33}$. Ainda em janeiro Covas pediu licença do cargo para tratar de um câncer, e Alckmin assumiu interinamente. Um indício da importância política de Covas em São Paulo e de sua imagem perante os eleitores pode ser encontrado nas romarias realizadas por fiéis católicos pela recuperação de sua saúde.

Com essa reviravolta no governo paulista, Eliane Cantanhêde, então colunista da Folha de S. Paulo, fez uma análise interessante que vale a pena ser ressaltada. Segundo ela, a possibilidade de Covas sair de cena e ser sucedido no governo paulista afetava não só a esfera estadual como também a federal, e incidiria sobre as candidaturas tucanas em 2002 para presidente, governador e senador. Covas, como uma das lideranças nacionais do PSDB na época, estava procurando articular a candidatura de Tasso Jereissati, então governador do Ceará pelo PSDB, para Presidente da República, chegando a declarar apoio público. Com isso, ele desprezou José Serra, que seria até o momento o nome mais previsível para assumir a sua herança na política nacional.

\footnotetext{
${ }^{31}$ Folha de S. Paulo, Primeiro Caderno, 1 de janeiro de 2001.

${ }^{32}$ Essas desavenças políticas se iniciaram em meados de 1999, quando o Presidente da República Fernando Henrique Cardoso sancionou uma lei, aprovada no Congresso sob a orientação da bancada pefelista baiana, que concedia incentivos fiscais para a instalação de montadoras no Brasil. A lei, originária de uma Medida Provisória, beneficiava a Ford, que decidiu levar a montadora para a Bahia e não para o Rio Grande do Sul, como estava previsto inicialmente. Em uma conversa telefônica vazada na época, ACM teria dito a FHC que deixaria de apoiar seu governo se ele vetasse integralmente a MP da Ford. A concessão de incentivos fiscais advinda daí opôs Covas, que era contrário à medida, ao então senador Antônio Carlos Magalhães (PFL-BA), que a defendia. Em entrevista ao Estado de S. Paulo em 10 de julho de 1999, Covas afirmou que "com a instalação a Bahia produziria automóveis com um custo muito mais barato do que em outros estados" e que "a concessão pode acabar prejudicando todo o país, além de ser ruim também para os outros estados: seria uma concorrência predatória absolutamente descabida”. Ver também: http://www.senado.gov.br/noticias/opiniaopublica/inc/senamidia/historico/1999/7/zn07088.htm

${ }^{33}$ Folha de S. Paulo, Primeiro Caderno, 19 de janeiro de 2001.
} 
Ao seguir um caminho avesso ao que se esperava na escolha dos aliados intrapartidários, Covas abriu uma disputa no PSDB nacional, a qual se propagou por seu estado. Alckmin era o substituto perfeito aos seus olhos: era leal e, por isso, conveniente e precioso. Covas era quem dava as cartas do jogo político e, como observou Cantanhêde, "na sua falta, os demais passam a matutar aquela perversidade do poder: 'Por que o Tasso e não eu?' Ou: 'Por que o Alckmin e não eu?',34. Todavia, com Covas vivo, a política paulista estava apoiada nele, em Maluf e no PT, um tripé presumível e firme. Desse modo, o PSDB em São Paulo, para enfrentar as duas outras forças políticas do estado, precisava encarar Covas, já que ele funcionava como um interlocutor entre tucanos e petistas.

Dada a indefinição da melhora do estado de saúde de Covas, na época o tempo limite que ele poderia se afastar do governo suscitou dúvidas e discussões. Pela Constituição do Estado de São Paulo o afastamento do cargo é previsto em apenas duas situações: viagem superior a 15 dias ou impedimento em casos não especificados pela lei. Alguns advogados defendiam que a licença de Covas poderia se estender até o final do mandato, outros diziam que ela tinha um caráter provisório. Alguns, ainda, argumentavam a favor do direito da Assembleia Legislativa de solicitar a sucessão governamental. A Constituição do estado, no entanto, não é omissa quanto às possibilidades de sucessão. Prevê que o vice-governador assume legalmente o cargo quando existir vacância em caso de morte, renúncia ou por meio de um processo de impeachment. Covas, mesmo relutante, afastou-se formalmente, todavia, instalado em uma das salas do Palácio dos Bandeirantes, acompanhava de perto a agenda do governo.

No final de fevereiro, o seu quadro de saúde se agravou e ele foi internado com infecção generalizada. Em 6 de março de 2001 morreu de falência múltipla dos órgãos, aos setenta anos de idade, no Instituto do Coração. Era o fim da era Covas em São Paulo e no PSDB. A elite política brasileira tinha levado um baque: para muitos ele estava para os tucanos assim como Ulysses Guimarães esteve para o PMDB.

Independentemente do partido, os políticos reconheciam a liderança de Covas construída ao longo de seus quarenta anos de vida pública. Entre eles estava Luís Inácio Lula da Silva que, tendo sido congressista juntamente com Covas na Assembleia Nacional Constituinte, asseverou que o tucano tinha sido um "adversário leal" 35 . O governo Covas em São Paulo deixou para Alckmin, seu pupilo e agora sucessor no cargo, um estado com

\footnotetext{
${ }^{34}$ Folha de S. Paulo, Primeiro Caderno, 23 de janeiro de 2001.

${ }^{35}$ Folha de S. Paulo, Primeiro Caderno, 07 de março de 2001, p. 3.
} 
dívidas renegociadas, previsão de um superávit primário de 3 bilhões de reais e uma imensa agenda de entregas. No entanto, sabia-se que a herança política do covismo abriria uma luta entre os tucanos paulistas e poderia não ser tão facilmente herdada por Geraldo Alckmin.

\subsection{Eleições 2002: a vitória de Geraldo Alckmin, o pupilo e herdeiro político de Covas}

Antes mesmo da morte de Covas, já se questionava se Alckmin poderia ser candidato ao governo em 2002, caso substituísse em definitivo o governador. Com a aprovação da emenda da reeleição em $1997^{36}$, a questão era sobre a legalidade da sua disputa, pois ele já havia substituído Covas por duas vezes. Enquanto o alvo das especulações declarava que sua prioridade era cumprir os compromissos do governo enquanto Covas estivesse licenciado, alguns argumentavam em favor da sua candidatura, defendendo que ele poderia ser reconduzido apenas mais uma vez ao cargo; já outros, contrários, afirmavam que, tendo ele substituído Covas nos dois mandatos, não poderia se candidatar, uma vez que já havia ocupado o cargo por duas vezes.

Para a cúpula do PSDB, Alckmin era claramente um nome em ascensão e, ao possuir condições políticas, financeiras e administrativas notavelmente boas, poderia, além de suceder Covas no governo, ser seu sucessor político. Entretanto, os líderes psdebistas sabiam que o então senador e ministro da Saúde, José Serra, seria um ponto duvidoso na escalada de Alckmin. Mesmo sendo aliados na política local, algumas lideranças achavam que com a morte de Covas as circunstâncias colocariam um contra o outro.

Outro obstáculo à consolidação de Alckmin como herdeiro do covismo poderia ser o inconformismo de outros tucanos paulistas com a sua ascensão. Era sabido que José Aníbal, na época secretário de Ciência e Tecnologia de São Paulo, e a deputada federal Zulaiê Cobra, que já havia disputado as prévias do partido com Alckmin pela candidatura à prefeitura de São Paulo em 2000, detinham bases de apoio no estado e cogitavam concorrer para disputar a vaga do governo de SP. As possíveis dificuldades que Alckmin teria de enfrentar com a morte de Covas eram muitas; a maioria dizia respeito à sua aceitação ou não por seus aliados teóricos.

\footnotetext{
${ }^{36}$ Até 1997, a lei vedava a reeleição de ocupantes de cargos executivos. Os vices que pretendiam disputar outros cargos não podiam suceder ou substituir o titular nos seis meses antes da eleição.
} 
Agora como governador, Alckmin enfrentou no início de 2002 uma grave crise na segurança do estado, fato que, somado às disputas internas do partido, deixava sua candidatura ainda mais vulnerável. O assassinato, em janeiro, do prefeito de Santo André, o petista Celso Daniel, que havia sido escolhido o coordenador da campanha presidencial de Lula em 2002, intensificou o problema e expôs o governo paulista. A relevância de fatos considerados, à primeira vista, marginais para uma boa compreensão da história, é apontada por Alexis de Tocqueville, que diz

\begin{abstract}
“(...) que muitos fatos históricos importantes só podem ser explicados por circunstâncias acidentais e que muitos outros são inexplicáveis; e enfim que o acaso - ou antes o entrelaçamento de causas secundárias, que assim chamamos por não sabermos desenredá-las - tem um grande papel em tudo o que vemos no teatro do mundo" (TOCQUEVILLE, 2011, p. 104).
\end{abstract}

A morte de Celso Daniel foi um acontecimento inesperado que, no contexto vivido por SP de crise na segurança pública, funcionou como a última gota num copo d'água, tendo em vista que quem tinha morrido não era mais uma pessoa comum, e sim um político do principal partido de oposição ao PSDB, que teria um papel-chave na campanha nacional do PT. Diante das circunstâncias, os tucanos tiveram como única saída tentar despartidarizar a crise. O PSDB utilizou espaço no rádio e na televisão para dar uma satisfação à população e, com isso, minimizar possíveis danos ${ }^{37}$.

As medidas tomadas por Alckmin nesse sentido devem ser ressaltadas. Primeiro, o governador retirou do "caso Celso Daniel” o delegado Romeu Tuma Júnior, filho do senador pefelista Romeu Tuma, a fim de não passar a impressão de que a investigação tinha sido politizada. Visando dar uma resposta técnica à crise, também trocou o secretário de Segurança Pública do estado. Além disso, em reunião com o presidente Fernando Henrique Cardoso, apresentou um programa com 13 providências referentes à questão em crise, apontando que o problema também seria de responsabilidade do governo federal, visando provavelmente minimizar os dados que seu governo sofreria juntamente com a sua imagem e competência para encabeçar a eleição que estava por vir.

\footnotetext{
${ }^{37}$ A inserção do PSDB nos meios de comunicação se iniciou menos de uma semana depois do assassinato de Celso Daniel. Em um trecho: "O PSDB usa esse espaço para se solidarizar com o PT e a população de Santo André, pelo assassinato do prefeito Celso Daniel. É um crime brutal, que merece a repulsa e o esforço de todos na caça aos assassinos. Não é hora de fazer exploração política em cima da dor e da brutalidade". (Folha de S. Paulo, 24 de janeiro de 2002).
} 
À medida que ele tentava administrar a crise da segurança em São Paulo, surgiam mais problemas: ações do Primeiro Comando da Capital (PCC) pelo estado, rebeliões em presídios, o sequestro do apresentador Silvio Santos e a posterior morte do sequestrador, além dos assassinatos de Toninho do PT, prefeito de Campinas, em 2001, e depois de Celso Daniel. Já mais perto das eleições, em junho, e priorizando o interior, Alckmin anunciou um pacote de medidas para combater a violência em Campinas e a desativação da cadeia pública de Vila Branca, que era a mais antiga e complicada unidade prisional de Ribeirão Preto. Além disso, segundo reportagem de Julia Duailibi e Cláudia Croitor $^{38}$, concedeu no primeiro semestre de 2002 mais carros de polícia (2.104) do que em todo o ano de 2001 (386), estando presente na maioria dos eventos de entrega. Ainda de acordo com a matéria, "O interior, que conta com o lobby de deputados, recebeu quase o mesmo número de unidades que a capital e cidades da Grande São Paulo, onde se concentram os números da violência".

Ainda no final de janeiro, Eliane Cantanhêde comentou na Folha de S. Paulo que "Os sequestros, sozinhos, não determinam a derrota e muito menos a vitória de Alckmin em outubro. Tudo depende de como ele e sua política enfrentarem a situação"39. Em São Paulo, a publicização de baixos índices de violência conjugados com altos indicadores de encarceramento até hoje rende ao governo um bom apoio por parte dos paulistas.

Em entrevista à Folha em 2002, quando interpelado sobre a crise na segurança, Alckmin disse: "Meu governo trabalha com a polícia, e a polícia do meu governo está trabalhando. Estamos com 260 sequestradores presos no estado e 18 foram mortos" ${ }^{\text {} 40}$. Na verdade, todos os possíveis candidatos ao governo de São Paulo nas eleições de 2002 - em janeiro, José Genoíno já era pré-candidato do PT e Luiza Erundina era dada como certa pelo Partido Socialista Brasileiro (PSB) - deveriam saber como tratar a questão em benefício próprio, sabendo que segurança e violência sempre se colocaram como aspectos importantes para a população e, por isso, bem explorados por aqueles que pleiteavam governar o estado.

Em abril, os principais pré-candidatos já estavam escolhidos em São Paulo nos principais partidos: Geraldo Alckmin (PSDB), José Genoíno (PT) e Paulo Maluf (PPB).

\footnotetext{
${ }^{38}$ Folha de S. Paulo, Primeiro Caderno, 29 de julho de 2002, p. 9.

${ }^{39}$ Folha de S. Paulo, Primeiro Caderno, 27 de janeiro de 2002, p. 2.

${ }^{40}$ Folha de S. Paulo, Primeiro Caderno, 25 de janeiro de 2002, p. 6.
} 
Assim como esperado, a violência foi apontada por todos como o tema prioritário de suas campanhas. Essa questão já havia sido um dos assuntos mais abordados por Maluf nas eleições anteriores, quando disputou com Covas, e funcionava como sua principal bandeira no estado.

Conhecido por mobilizar a violência como tema, Maluf, que chegou a propor a reativação do complexo do Carandiru, voltando atrás depois, em 2002, não foi o único a lidar com o problema. Alckmin e Genoíno também o tinham como prioridade, devido às circunstâncias. O petista lançou um programa de governo que tinha como pontos principais o combate à criminalidade. Já o candidato à reeleição, além das medidas já citadas, em maio propôs um pacote de segurança para as escolas, todavia, visando não dar margem aos comentários e ataques dos adversários sobre a segurança pública em São Paulo, procurou polarizar o debate no segundo ponto prioritário de sua campanha, que era a questão do desenvolvimento que incluía a criação de empregos, geração de renda e, mais especificamente, a construção da alça sul do Rodoanel. A ideia era dar visibilidade à melhoria dos índices sociais no horário eleitoral gratuito, o que, mesmo indiretamente, indicaria um ponto positivo na luta contra a violência no estado.

Diante da publicação, em março, pela Fundação Seade/Dieese de uma taxa de desemprego de 19,9\% na região metropolitana e aumento do número de desempregados no estado, Alckmin, mais uma vez tentando se desvencilhar das críticas, atribuiu tais índices à política econômica implantada pelo governo federal. Segundo Julia Duailibi e Maria Inês Nassif, "O plano de governo [de Alckmin previa] um polo de geração de empregos no interior, região que [preocupava] os tucanos. De acordo com pesquisas encomendadas pelo partido, [era] principalmente no interior que [estava] o eleitor suscetível ao discurso duro sobre segurança usado por Maluf" ${ }^{41}$. Genoíno seguiu Alckmin ao focar em políticas de desenvolvimento e apresentou, em maio, um pacote de grandes obras viárias e de infraestrutura.

A reunião da Executiva do PSDB para discutir a conjuntura eleitoral e tratar das pré-candidaturas em São Paulo ocorreu em meados de janeiro de 2002; Alckmin foi oficializado como candidato do partido somente no final de junho. Antes do anúncio, no entanto, como já se previa, Zulaiê Cobra se lançou pré-candidata ao governo paulista mesmo sabendo que suas chances eram mínimas, alegando que pretendia fortalecer seu

\footnotetext{
${ }^{41}$ Folha de S. Paulo, Primeiro Caderno, 12 de maio de 2002, p. 10.
} 
nome para a eleição seguinte. Alckmin saía na frente graças ao apoio da maioria do diretório estadual. Talvez por concorrer sem perspectiva de vitória ou por pressões intrapartidárias, a deputada acabou retirando sua pré-candidatura.

Antes mesmo de ter sua candidatura oficializada, Alckmin e o partido já tinham iniciado os trabalhos para a construção das alianças. O PFL, que não fez parte da coligação de Covas em 1998, já era dado como certo na aliança psdebista, no entanto, decidiu atrasar o acordo a fim de observar como a crise na segurança do estado afetaria a imagem de Alckmin. Os pefelistas chegaram a insinuar o lançamento da candidatura do senador Romeu Tuma para o governo, mas, ao refletirem que ele teria mais chances caso concorresse novamente ao Senado, decidiram apoiar Alckmin e o PSDB e pressionaram para ter o candidato a vice-governador, o que conseguiram com o nome de Claudio Lembo. Isso gerou críticas entre tucanos, especialmente aqueles ligados a Mário Covas, que preferiam uma chapa pura. Jaime Pereira, na época dirigente zonal do PSDB paulistano, disse que "Lembo representa o regime militar, que tantos tucanos lutaram para combater" ${ }^{\circ 2}$, referindo-se ao início da carreira política do candidato a vice-governador na Arena.

Em 26 de fevereiro, uma formalidade ameaçou a aliança do PSDB com o PFL em São Paulo. O Tribunal Superior Eleitoral tinha aprovado a obrigatoriedade de as coligações para os governos estaduais seguirem as alianças para a eleição presidencial. $\mathrm{O}$ PFL tinha Roseana Sarney como pré-candidata à presidência da República, assim como o PSDB tinha José Serra. A decisão do TSE estabelecia que os partidos que apoiassem determinado candidato a presidente não poderiam nos estados se aliar com legendas que estivessem coligadas a outra candidatura à presidência. Em suma, o Tribunal vetava, a partir daquele momento, alianças estaduais entre partidos que apresentassem candidato ao cargo máximo do Poder Executivo federal ou que apoiassem uma candidatura, de modo que a possibilidade apenas de aliança vertical obviamente prejudicava Alckmin.

Em março, depois de vários recursos impetrados pelos partidos nas instâncias legislativa e judiciária, o TSE decidiu liberar as alianças estaduais com partidos que não disputassem diretamente o Planalto. Em abril, Roseana Sarney, diante de uma série de acusações e denúncias de desvio de recursos públicos, decidiu retirar-se da disputa presidencial, o que deixou seu partido livre para participar de coligações nos estados.

\footnotetext{
${ }^{42}$ Folha de S. Paulo, Primeiro Caderno, 09 de janeiro de 2006, p. 4.
} 
Tendo resolvido a aliança com o PFL, que na época, junto com PSDB e PT, era um partido em ascensão, principalmente em São Paulo, Alckmin demonstrou preocupação em ficar sem o apoio do PTB, que em parceria com PPS e PDT poderia lançar candidato próprio buscando fortalecer a campanha de Ciro Gomes (PPS), que concorria à presidência da República. Mesmo que tenha se reunido com deputados petebistas, o que o tucano temia ocorreu: em fevereiro o PTB anunciou a pré-coligação com o PDT, aderindo a Ciro Gomes no âmbito nacional. Antônio Cabrera Mano Filho, nome do PTB, ficou em sétimo lugar na disputa. Mesmo com a impossibilidade de uma aliança formal entre PSDB, PPS e PTB por causa da verticalização das coligações, Ciro Gomes, em meados de agosto, expôs publicamente seu apoio a Geraldo Alckmin em São Paulo.

Alckmin também recebeu apoio da Força Sindical, central que, à época, reunia cerca de mil sindicatos e representava aproximadamente 5 milhões de trabalhadores em São Paulo. Além disso, desde 2001, com a morte de Covas, o governador vinha costurando apoio de prefeitos de outros partidos além da aliança PSDB-PFL, sendo eles filiados ao PPS, PTB, PDT, PSB e até mesmo ao PT. Segundo palavras dele, “aliança não se faz baseado em simpatias ou antipatias pessoais" ${ }^{\prime 43}$.

Próximo às eleições, os principais líderes tucanos em cada uma das 15 regiões administrativas de São Paulo orientavam os prefeitos que apoiavam o governador a irem para as ruas, rádios e palanques, para que pudessem pregar o voto em Alckmin. O coordenador da campanha do candidato psdebista, João Carlos Meirelles, chegou a dizer que o governador contava com o apoio de 531 dos 615 prefeitos de São Paulo na época ${ }^{44}$, os quais justificavam o apoio dizendo que Alckmin era muito atencioso com as cidades.

Apesar disso, as pesquisas em 2002 apontavam fraco desempenho do tucano no interior, quando comparado a Maluf, que procurava rádios interioranas e se oferecia para ser entrevistado. Quando perguntado sobre isso, respondeu: "Engraçado isso. Sou um caipira do interior, mas os índices são maiores na região metropolitana. A campanha [para a prefeitura de SP] não chegou ao interior, só à capital. No interior, não tenho o mesmo nível de conhecimento que tenho na capital. (...) Estou viajando e estou vendo isso"45.

Nesse pleito, o PSDB preparou material específico para cada cidade, no qual pormenorizava todas as suas ações. Segundo reportagem de José Alberto Bombig, que

\footnotetext{
${ }^{43}$ Folha de S. Paulo, 01 de abril de 2002, p. 6.

${ }^{44}$ Folha de S. Paulo, 16 de agosto de 2002.

${ }^{45}$ Folha de S. Paulo, 01 de abril de 2002, p. 6.
} 
utilizava dados do sistema de informação de acompanhamento de execução orçamentária, a região do Vale do Paraíba, entre janeiro e agosto de 2002, tivera o maior aumento nos valores empenhados ${ }^{46}$ pelo estado para investimentos diretos, em comparação ao mesmo período de 2001. Para exemplificar, São José dos Campos em 2002 recebeu do estado 25,8 milhões, ao passo que no ano anterior tinha recebido apenas 8,1 milhões, o que representou uma variação de 215\%. Já Pindamonhangaba, cidade natal de Alckmin, teve um incremento de $740 \%$ nos investimentos, adicionando a verba repassada pelo estado por meio de convênios.

A campanha no primeiro turno foi marcada por várias reviravoltas nas pesquisas de intenção de voto. Não obstante a crise vivida pelo malufismo em São Paulo, Maluf, agora com o apoio de partidos menores - PL, PSDC e PTN -, representando um "puxador de votos" para os parlamentares aliados, aparecia, no início de setembro de 2002 , segundo pesquisa do Datafolha, em primeiro lugar na disputa, com 35\%, seguido por Geraldo Alckmin (PSDB) com 25\% e José Genoíno (PT) com 17\%.

Prenunciando o que ocorreria nos meses seguintes, o destaque da pesquisa, divulgada pela Folha de S. Paulo ${ }^{47}$, era o de que em um mês a intenção de voto para Maluf tinha decaído cinco pontos percentuais e a de Genoíno tinha aumentado sete. Ao mesmo tempo, a rejeição ao primeiro havia aumentado e a do segundo, diminuído. Os dois primeiros colocados até aquele momento tinham eleitores de perfis diferentes, segundo as apurações. Conforme o Datafolha ${ }^{48}$, Maluf se destacava principalmente entre os homens mais velhos, entre os eleitores que moravam no interior e os de menor renda e baixo grau de escolaridade. Ao contrário, Alckmin era preferido entre as mulheres, os mais jovens e os de maior escolaridade e renda.

Com uma porcentagem de intenção de voto superior à dos dois outros adversários juntos, a hipótese é que Maluf se beneficiou, no início da campanha, de seu aparecimento, no período pré-eleitoral, nos meios de comunicação de massa antes que seus adversários, concentrando em si os votos de protesto ao governo, como opinou o cientista político Fernando Abrucio na época ${ }^{49}$.

\footnotetext{
${ }^{46}$ Valores empenhados são aqueles que o governo autoriza para serem utilizados em obras e na aquisição de materiais permanentes como ambulâncias e aparelhos hospitalares, por exemplo.

${ }^{47}$ Folha de S. Paulo, Folha Eleições, quarta-feira, 11 de setembro de 2002, p. 1.

${ }^{48}$ Folha de S. Paulo, Primeiro Caderno, 25 de fevereiro de 2002, p. 5.

${ }^{49}$ Análise divulgada na Folha de S. Paulo, Eleições, segunda-feira, 7 de outubro de 2002, p. A 5.
} 
Entretanto, a ascensão de Maluf seria momentânea por vários motivos. Um deles relaciona-se à quebra de sua reputação política. Em agosto de 2001, ele foi acusado de ter uma conta bancária num paraíso fiscal, de enriquecimento ilícito, evasão de divisas e improbidade administrativa, o que levou a Justiça a determinar a quebra do sigilo seu sigilo bancário, fiscal e telefônico a partir de janeiro de 1993. Além disso, ele, sendo ex-prefeito da capital (1993-1997), enfrentaria a CPI municipal da Dívida Pública que iria apurar o endividamento do município desde a gestão Jânio Quadros (1986-1988). Somado a isso, sua imagem ficara desgastada depois da péssima gestão de Celso Pitta, seu apadrinhado e sucessor na prefeitura de São Paulo.

Maluf, que começou bem melhor que os adversários, não resistiu à rejeição popular e à polarização do debate entre PSDB e PT, que possuíam discursos semelhantes, e, com isso, declinou a partir de meados de setembro daquele ano, quando pesquisa do Ibope $^{50}$ mostrou Alckmin um ponto percentual à sua frente (Maluf tinha então 28\%), enquanto Genoíno havia crescido cerca de dez pontos.

No final do mês de setembro, pesquisa do Datafolha ${ }^{51}$ corroborou tais resultados e indicou que Alckmin já liderava a disputa, à frente de Maluf e Genoíno. Quanto a esses dois candidatos, os institutos de pesquisa divergiam. A última pesquisa divulgada pelo Datafolha em outubro ${ }^{52}$ mostrava Maluf (27\%) na frente do petista $(24 \%)$. Já o Ibope ${ }^{53}$ considerava Genoíno (28\%) na frente de Maluf (27\%).

Diante do crescimento no país das forças políticas de esquerda e da "onda Lula", a equipe de Alckmin afirmava que o governador preferia enfrentar Maluf a Genoíno, embora ele mesmo nunca tenha admitido isso publicamente. Enquanto o candidato psdebista se apoiava na imagem de Mário Covas, Genoíno, que contava com o apoio do ex-governador pemedebista Orestes Quércia, amparou-se na imagem de Marta Suplicy, prefeita da capital, e do candidato à presidência pelo PT, Lula, que reforçou a agenda em SP e junto com o partido convocou reuniões com os prefeitos aliados.

Alckmin e Genoíno criaram fôlego, recuperaram-se e foram ao segundo turno. Na primeira fase da eleição, o candidato tucano ganhou em seis das dez maiores cidades administradas pelo PT, incluindo a capital, Ribeirão Preto e Piracicaba, onde obteve a

\footnotetext{
${ }^{50}$ Pesquisa Ibope divulgada em 16 de setembro de 2002.

${ }^{51}$ Folha de S. Paulo, Primeiro Caderno, 23 de setembro de 2002, p. 1.

${ }^{52}$ Folha de S. Paulo, Caderno Especial Eleições, 6 de outubro de 2002.

${ }^{53}$ Idem.
} 
maior vitória. Já o petista se saiu vitorioso em cinco dos dez maiores municípios com prefeitos psdebistas, entre eles São Bernardo do Campo e Jundiaí. PSDB e PT, dois partidos em ascensão, enfrentaram-se em São Paulo, e graças à definição de uma boa estratégia política, baseada, entre outras coisas, na aglutinação de apoio político, os tucanos foram os vitoriosos.

Alckmin, além do apoio de PFL e PSD, conseguiu no segundo turno o suporte do PTB, do PV, de parte do PDT, dos deputados do PPB, partido de Maluf, e da maioria dos deputados estaduais eleitos (50 de 94). Além disso, obteve o apoio público de alguns nomes como Arnaldo Jardim (PPS), Celso Russomanno (PPB) e Paulo Pereira da Silva, da Força Sindical.

José Genoíno, já tendo o apoio de PCdoB e PCB, angariou o apoiou do PL e de parte do PDT, além da adesão do candidato derrotado do PTB em SP, Antônio Cabrera, e do também derrotado Paulo Maluf, bem como de João Hermann (PPS), Luiz Antônio de Medeiros (PL) e Edinho Araújo (PPS), que era prefeito de São José do Rio Preto. O petista saiu prejudicado nas alianças ao desagradar tanto aos ruralistas como aos sem-terra do Pontal do Paranapanema ${ }^{54}$, região que compreende 32 municípios. Se, por um lado, os ruralistas não esqueciam que Genoíno havia participado nos anos 70 da Guerrilha do Araguaia $^{55}$, por outro, os sem-terra desconfiavam da linha "frágil”" do PT.

Alckmin, que ganhou a disputa em segundo turno contra o candidato petista, possuía esmagadora preferência (49\%) nos municípios do Vale do Paraíba, embora tenha obtido melhor desempenho na região no primeiro turno. Ele e o PSDB venceram em todas as macrorregiões de São Paulo, mesmo naquelas em que o PT concentrava prefeituras. Entre alguns municípios que preferiram Alckmin estavam Ribeirão Preto, Campinas, Franca, São Carlos, Jacareí, Araraquara, a capital e o litoral sul, onde se localizava Santos, cidade natal de Mário Covas.

\footnotetext{
${ }^{54}$ Localizado no extremo oeste de São Paulo, o Pontal do Paranapanema abriga o foco do principal conflito agrário no estado, devido à falta de precisão jurídica acerca da posse de muitas das propriedades da região. No decorrer do século XX, muitos dos fazendeiros que ocupam a área compraram terras de antigos grileiros ou ocuparam áreas públicas. O Movimento dos Trabalhadores Rurais sem Terra (MST) prioriza a região justamente pela imprecisão na posse da terra, o que o faz realizar invasões.

${ }^{55}$ A Guerrilha do Araguaia foi um movimento guerrilheiro criado pelo Partido Comunista do Brasil (PCdoB) que ocorreu ao longo do rio Araguaia, na Amazônia, entre as décadas de 1960 e 1970. O movimento tinha por objetivo iniciar no campo uma revolução socialista; a região escolhida foi a povoada ao longo do Araguaia, tendo em vista que seus habitantes, fugindo em sua maioria da seca do Nordeste, trabalhavam em fazendas em regime de escravidão, sob o domínio de latifundiários e autoridades corruptas. Em abril de 1972, José Genoíno foi o primeiro guerrilheiro capturado e preso, sendo enviado à Brasília para ser interrogado. Ver: http://www.cartacapital.com.br/politica/jose-genoino-e-o-araguaia.
} 


\subsection{O decorrer do primeiro mandato como governador e a derrota para Presidente em 2006}

Dois anos após vencer sua primeira eleição para o governo de São Paulo, em 2005, a eleição da presidência da Assembleia Legislativa foi o desafio que Alckmin teve de enfrentar. O governador tinha interesse que o deputado psdebista Edson Aparecido, seu aliado desde a época em que ele presidia o PSDB paulista, fosse o nome escolhido, o que facilitaria a aprovação no Legislativo de projetos importantes advindos do Executivo.

Para viabilizar a eleição de Aparecido, cujo principal adversário era o deputado Rodrigo Garcia (PFL), que surpreendentemente fazia parte do partido da base governista, a equipe de Alckmin, colocando em jogo as transferências de recursos para os municípios, acionou os prefeitos do interior para que eles pressionassem os respectivos deputados estaduais a votar como indicava o Palácio dos Bandeirantes. Alckmin chegou a receber em seu gabinete 48 deputados. Um deles, o deputado Tiãozinho da Farmácia (PV), o qual, teoricamente, deveria apoiar a candidatura de Garcia, disse após conversa com Alckmin: "Estou sempre precisando do governo do estado, que sempre me ajudou, na medida do possível. Agora, é hora de retribuir" ${ }^{, 56}$.

Apesar disso, tal esforço não foi suficiente. Em uma aliança com os deputados do PT, Garcia venceu Aparecido por 48 votos a 46, o que acabou com a hegemonia que o PSDB tinha na presidência da Assembleia há dez anos. A derrota de Aparecido significava a derrota de Alckmin.

Sabendo que o jogo político e a detenção do poder envolvem a barganha de favores e o peso pelos envolvidos das oportunidades disponíveis a curto, médio ou longo prazo, uma das interpretações cabíveis é a de que, “(...) ao que parece, as corporações parlamentares perceberam que alianças de ocasião para derrotar o Executivo criam uma oportunidade mais propícia à detenção de vantagens fisiológicas do que aquela oferecida por negociações prévias com vistas a sancionar a candidatura governista" ${ }^{27}$. Nesse contexto, cada decisão dos deputados que derrotaram Alckmin seria equivalente a uma troca de favores com o Executivo: a junção perfeita entre oportunismo e fisiologismo político.

\footnotetext{
${ }^{56}$ Folha de S. Paulo, Primeiro Caderno, 15 de março de 2005, p. 8.

${ }^{57}$ Folha de S. Paulo, Primeiro Caderno, 16 de março de 2005, p. 8.
} 
Nessa época, Alckmin já cogitava ser escolhido pelo PSDB para concorrer ao Palácio do Planalto, embora não tenha assumido isso até agosto de 2005. Apresentando-se como um exemplo de capacidade administrativa, em maio de 2005 Alckmin lançou um programa para acelerar a execução de 46 projetos que representavam um investimento de 12,3 bilhões de reais. Entre os dez projetos de mais alto investimento estavam aqueles relacionados à inteligência policial, modernização e ampliação do sistema prisional, que previam a construção de presídios e a descentralização da FEBEM, bem como projetos de educação. Além disso, travou com Lula, candidato petista à reeleição, um debate direto, certamente a fim de se colocar antecipadamente como candidato virtual.

A disputa, incitada por Alckmin, incluiu questões relacionadas à reforma agrária e à segurança pública, e resultou até mesmo na paralisação de obras e projetos em São Paulo, tendo em vista, segundo os tucanos, a diminuição e o atraso nas transferências de recursos da União para o estado em áreas prioritárias. A resposta oficial do Governo Federal foi que São Paulo não era o único estado a enfrentar tal situação. No entanto, segundo reportagem de Duailibi e Bombig ${ }^{58}$, a retenção de recursos federais parecia ter sido proposital, diante do fato de que o governador de São Paulo havia atuado nos bastidores contra o candidato do Planalto à presidência da Câmara dos Deputados, o paulista Luiz Eduardo Greenhalgh $(\mathrm{PT})^{59}$. Na ocasião, Greenhalgh foi derrotado pelo polêmico deputado Severino Cavalcanti (PP).

Após a derrota para o PFL de seu candidato para a Assembleia Legislativa paulista, Alckmin ficou mais reticente em entregar o governo para se candidatar à presidência da República, já que deixaria o cargo para o vice, o pefelista Cláudio Lembo. Somada a essa incerteza política estava a fragilidade administrativa vivida pelo governo, diante da crise no sistema prisional, que não era algo novo, assim como rebeliões na FEBEM e a explosiva dívida da Companhia Energética de São Paulo (CESP).

No entanto, mesmo sem assumir publicamente que postulava ser candidato em 2006, Alckmin não sumiu nas pesquisas de intenção de voto. Em consulta feita pelo Datafolha $^{60}$ com cem empresários, o nome de Alckmin apareceu como o mais forte para

\footnotetext{
${ }^{58}$ Folha de S. Paulo, Primeiro Caderno, 6 de março de 2005.

${ }^{59}$ Greenhalgh, um dos membros fundadores do PT, foi vice-prefeito de São Paulo no governo de Luiza Erundina (1989-1993). Além disso, foi o advogado do PT responsável por acompanhar as investigações do assassinato do ex-prefeito de Santo André, Celso Daniel, caso que trouxe algumas dores de cabeça para Alckmin.

${ }^{60}$ Pesquisa divulgada na Folha de S. Paulo no dia 4 de maio de 2005, p. 4.
} 
enfrentar Lula: 38\% dos entrevistados tinham a percepção de que o governador de São Paulo poderia vencer o petista. Em contraponto, pesquisa do instituto Ipsos $^{61}$, encomendada pelo PSDB, mostrava que José Serra era o nome com maiores chances de disputar em 2006, com 24\% das intenções de voto, enquanto Alckmin aparecia com 14\%. Era evidente que a disputa tucana pela candidatura ao Planalto seria entre Alckmin e Serra, que, pelas pesquisas, era o favorito para enfrentar Lula, e também o nome preferido pelo aliado PFL.

Apesar disso, Alckmin perseverou e saiu vitorioso da disputa intrapartidária pela candidatura ao Planalto. Em janeiro, anunciou que deixaria até $1^{\circ}$ de abril de 2006 o cargo de governador para tentar concorrer à presidência da República. Obtendo o apoio de 22 deputados tucanos da Assembleia Legislativa, sua candidatura, elogiada por empresários, foi anunciada em março. Alckmin se sobrepôs a Serra ao forçar sua desistência, dizendo que só deixaria a disputa caso fosse vencido numa convenção partidária, alternativa que não agradava ao tucano. Serra, que não compareceu ao evento de lançamento da candidatura de Alckmin, disse em nota que "seu senso de responsabilidade política" o levou a abdicar.

Todavia, ao que parece, uma série de fatores contribuiu para a vitória do governador paulista. Primeiramente, Serra estava indeciso quanto à sua candidatura, pois preferia que o partido estivesse unificado em torno do seu nome para concorrer à presidência, o que não ocorreu. Em contraposição, Alckmin insistiu na disputa interna, independentemente da divisão partidária. Costurou apoio com os demais governadores nos estados e negociou a aliança com o PFL. Com o suporte da burocracia do partido, Alckmin venceu Serra "por exaustão partidária e não por preferência das lideranças"62.

José Serra, então prefeito de São Paulo, foi apontado pelo partido para tentar a reeleição tucana no estado, deixando a prefeitura em 31 de março de 2006. Ele teve como principais adversários Aloizio Mercadante, do PT, e Orestes Quércia, do PMDB, que decidiu concorrer após Serra se negar a lhe dar a vaga de vice. O PSDB encabeçava a coligação "Compromisso com São Paulo", também formada por PFL, PTB e PPS. A coligação petista "Melhor para São Paulo" contava com partidos menores: PRB, PL e PCdoB. Já Quércia possuía apenas o apoio formal do PP.

\footnotetext{
${ }^{61}$ Pesquisa divulgada na Folha de S. Paulo no dia 25 de maio de 2005, p. 11.

${ }^{62}$ Opinião do colunista Fernando Rodrigues. Folha de S. Paulo, 15 de março de 2006, p. 2.
} 
Além das competições interpartidárias, essa eleição foi marcada pela disputa dentro do PSDB paulista entre Serra e Alckmin para formar suas bancadas, tendo em vista as eleições municipais de 2008 e a eleição nacional de 2010. Após deputados tucanos da Assembleia de São Paulo declararem apoio a Geraldo Alckmin na disputa com Serra pela vaga de candidato a presidente, o grupo serrista buscou eleger, com esforço próprio, alguns nomes de confiança para as câmaras estadual e federal, a fim de ter nas mãos o controle das duas bancadas, o que facilitaria a escolha de Serra para concorrer ao Planalto em 2010. Em outubro, a apuração da votação indicava que Serra teria uma Assembleia Legislativa favorável a ele, de modo que, dos cem candidatos mais votados para deputado, 44 eram do PSDB ou do PFL, e ainda, alguns dos eleitos eram nomes aliados ao tucano.

Pesquisa do Datafolha realizada a dois meses da eleição ${ }^{63}$ mostrava que o candidato psdebista possuía $49 \%$ das intenções de voto, contra 17\% de Mercadante e $10 \%$ de Quércia. Enquanto os peemedebistas voltavam ao cenário dos três primeiros colocados, o que não ocorria desde 1994, Mercadante, que repetia a segunda colocação do PT na eleição anterior, possuía dificuldade de associar-se à imagem de Lula, o que podia favorecê-lo diante do eleitorado. Teve ainda sua campanha abalada pelo "escândalo dos aloprados", também chamado de "escândalo do dossiê", episódio que eclodiu após um assessor de Mercadante ser pego entrando num hotel em São Paulo para supostamente comprar informações que prejudicariam o candidato tucano.

Serra, assim como Alckmin nas eleições anteriores, priorizou a segurança, evitando comentar as decisões de Cláudio Lembo (PFL), vice de Alckmin, que enfrentava uma crise nesse setor devido a ataques violentos do Primeiro Comando da Capital (PCC). Também teve de lidar em sua campanha com acusações que o envolviam no "esquema das sanguessugas" ${ }^{\text {64 }}$, quando foi ministro da Saúde em 2001, bem como com a polêmica do dossiê contra ele, comprado supostamente por petistas.

Ao enfrentar um candidato petista sem grande visibilidade em São Paulo e um peemedebista que estava há muito tempo marginalizado da política do estado, Serra venceu em primeiro turno com $57,93 \%$ dos votos válidos, o que foi inédito em todas as eleições

\footnotetext{
${ }^{63}$ Pesquisa Datafolha divulgada pela Folha de S. Paulo, Primeiro Caderno, 10 de agosto de 2006, p. 1.

64 "O esquema das sanguessugas" consistiu no desvio, que envolvia parlamentares, prefeitos e funcionários do alto escalão do governo federal, de aproximadamente 110 milhões de reais para a compra de ambulâncias destinadas a prefeituras de seis estados. Segundo a Polícia Federal, as propinas vinham por meio do superfaturamento dos veículos, que chegava a $260 \%$ do seu valor. Nas eleições de 2006, vieram à tona fotos nas quais José Serra (PSDB), então Ministro da Saúde, aparecia ao lado de deputados acusados de integrar a máfia, no momento da entrega das ambulâncias.
} 
para governador de SP ocorridas até aquele momento. Aloizio Mercadante ficou na segunda colocação, com 31,68\%.

Em dezembro de 2005, três meses antes de deixar o governo, pesquisa do Datafolha $^{65}$ mostrou que $62 \%$ da população paulista achava o governo de Alckmin bom ou ótimo; sua aprovação era maior no interior do estado (66\%). Além disso, explicitava que o governador se saía melhor entre os que tinham maior escolaridade e entre aqueles que ganhavam de cinco a dez salários mínimos. Lula, de acordo com reportagem feita pela Folha de S. Paulo em 30 de outubro de 2005, ganharia mais votos entre os beneficiados pelo Programa Bolsa Família.

Na eleição em 2006, apesar de Alckmin ter sido mais votado que Lula no estado de São Paulo no primeiro e no segundo turnos, perdeu a disputa, tendo recebido, no total da apuração, mais votos no primeiro turno do que no segundo, inclusive no estado que governava $^{66}$. Na segunda fase da eleição, Alckmin passou praticamente todo o tempo tentando dar explicações sobre as acusações do PT de que ele iria privatizar tudo no país. Para passar uma imagem diferente da de "privatizador", fez campanha vestido com roupas que tinham as logomarcas do Banco do Brasil, da Caixa, da Petrobras e dos Correios.

\subsection{A saga para o retorno de Alckmin: derrota consecutiva em 2008, secretário em 2009 e governador em 2010}

Após a derrota em 2006, Alckmin tentou ser presidente do PSDB. No entanto, José Serra e Aécio Neves o impediram. Em 2008, foi o candidato tucano para prefeito de São Paulo nas eleições municipais. O ex-governador foi apresentado como candidato único do partido após um acordo fechado por José Serra, que, embora negasse publicamente, preferiria apoiar Gilberto Kassab (DEM), seu vice e sucessor quando ele deixou a prefeitura em 2006.

Para o psdebista e ex-governador de São Paulo, Alberto Goldman, a decisão de Alckmin em concorrer para a prefeitura "foi um problema, porque o PSDB vinha participando com o Kassab no governo. Toda a prefeitura era nossa. Como você vai virar oposição?" ${ }^{67}$. Segundo pessoas próximas, Serra preferia apoiar Kassab, visando unificar o

\footnotetext{
${ }^{65}$ Pesquisa divulgada na Folha de S. Paulo no dia 18 de dezembro de 2005, p. 4.

${ }^{66} \mathrm{Ver}$ http://www.bbc.com/portuguese/reporterbbc/story/2006/10/061030_alckminapuracaocgdt.shtml.

67 “O paulista Ge-ral-do” por Julia Duailibi. Revista Piauí, n. 99, ano 8, 2014, dezembro, p. 24.
} 
DEM na aliança em torno de sua possível candidatura ao Planalto em 2010 e, ao mesmo tempo, enfraquecer deputados aliados de Alckmin, vistos como adversários serristas em São Paulo ${ }^{68}$. PMDB e DEM chegaram a manifestar apoio à candidatura de Alckmin em 2010 para governador, intentando, com sua desistência em concorrer para a prefeitura, manter o PSDB na aliança ${ }^{69}$. Em fevereiro de 2008, Alckmin, de acordo com as pesquisas, liderava a disputa para o cargo, seguido da petista Marta Suplicy e de Kassab.

Em agosto, a diferença entre o tucano e o candidato democrata havia caído pela metade: o primeiro aparecia com $24 \%$ das intenções de voto e o segundo, com $14 \%{ }^{70}$. Kassab, que crescia nas pesquisas da mesma forma que sua aprovação na prefeitura aumentava entre os paulistanos, disputou com Alckmin as vantagens do governo de Serra, tendo recebido ainda a colaboração de aliados do governador - e, alguns dizem, dele próprio - na sua candidatura.

Alckmin já não era desconhecido na capital, fato ao qual atribuiu a derrota em sua primeira disputa à prefeitura da capital em 2000, todavia ficou em terceiro lugar, com $22,48 \%$ dos votos válidos no primeiro turno nas eleições, oito anos depois. Marta com $32,79 \%$ e Kassab com 33,61\% seguiram para o segundo turno, e o pefelista acabou sendo o vitorioso.

Após mais uma derrota, Alckmin deixou a campanha com a imagem de Quixote - um idealista -, e fora do governo; “dava palestras e aplicava sessões de acupuntura num hospital público"71. No final de 2009, Serra preparava-se para ser candidato à presidência e enfrentar Lula em sua tentativa de reeleição. Ainda como governador de SP, observou que as pesquisas de opinião revelavam Alckmin como o candidato preferido para concorrer ao governo paulista em 2010. Após consultar alguns aliados como Alberto Goldman e Aloysio Nunes, Serra, na tentativa de unificar o partido, chamou Alckmin para fazer parte do seu governo.

Assim, "Geraldinho" assumiu em janeiro de 2009 o cargo de secretário estadual de Desenvolvimento. Desde então, priorizou sua agenda de viagens e inaugurações no interior de São Paulo. Pesquisa do Datafolha divulgada em meados desse

\footnotetext{
68 Ver Folha de S. Paulo em 24 de agosto de 2008. Ver também reportagem em http://politica.estadao.com.br/noticias/geral,alckmin-serra-e-importante-nome-do-psdb-para-2010,309643. 69 Ver $\quad$ http://g1.globo.com/Noticias/Politica/0, MUL424988-5601,00$\mathrm{DEM}+\mathrm{E}+\mathrm{PMDB}+\mathrm{APOIAM}+\mathrm{ALCKMIN+EM+PARA+TER+APOIO+TUCANO+A+KASSAB} \cdot h t m l$.

${ }^{70}$ Pesquisa Datafolha divulgada pela Folha de S. Paulo em 24 de agosto de 2008, p. 1.

71 “O paulista Ge-ral-do" por Julia Duailibi. Revista Piauí, n. 99, ano 8, 2014, dezembro, p. 24.
} 
ano mostrava que o tucano possuía entre $47 \%$ e $50 \%$ das intenções de voto, a depender de quem seriam seus concorrentes. Embora a petista Marta Suplicy tivesse sinalizado ao partido que não disputaria o governo, colocando-a como adversária de Alckmin, a pesquisa evidenciava que a distância entre ambos no estado seria de aproximadamente 32 pontos percentuais, a qual aumentava se fosse considerado apenas o interior: Alckmin, nesse caso, teria $53 \%$, e Marta, $10 \%$.

O fato é que as candidaturas ainda não estavam certas. O PT ainda não tinha um nome definido para a eleição de 2010. Chegou a cogitar apoiar a candidatura, bem vista aos olhos de Lula, de Ciro Gomes (PSB) em São Paulo, o que implicaria a mudança de domicílio eleitoral desse. Em novembro de 2009, Edinho Silva, presidente do Diretório Estadual do PT, anunciou que o partido apoiaria Ciro Gomes (PSB) ou teria candidatura própria.

O nome de Antonio Palocci era uma alternativa, caso ele fosse absolvido do julgamento pela acusação de ter, enquanto ministro da Fazenda, quebrado o sigilo bancário do caseiro Francenildo Costa, fato que ocorreu no âmbito do escândalo do Mensalão ${ }^{72}$. Alckmin também não estava garantido como candidato. Aloysio Nunes, secretário da Casa Civil de Serra, poderia ser um concorrente interno e contava com o apoio do PMDB e do DEM, partido que, por sua vez, poderia aceitar Gilberto Kassab como candidato a governador.

Ao final, nenhum dos candidatos cogitados pelo PT em meados de 2009 vingou. Em setembro do mesmo ano, Paulo Skaf, presidente da Federação das Indústrias do estado de São Paulo, filiou-se ao PSB, com possibilidades de se lançar candidato ao governo paulista, já que o partido buscava ampliar seu poder em São Paulo. A précandidatura de Skaf, que, amigo de Alckmin, tinha elogiado a sua escolha pelo PSDB para concorrer à presidência em 2006, foi confirmada em janeiro de 2010.

A perspectiva da candidatura de Ciro Gomes, nome preferido de Lula, foi afastada diante da decisão do PT paulista de indicar um candidato próprio da sigla. Entre as alternativas estavam os nomes de Palocci, Eduardo Suplicy, Fernando Haddad, Emídio de Souza, Arlindo Chinaglia e Aloizio Mercadante, que, embora fosse mencionado, tinha manifestado seu desejo de se reeleger ao Senado.

\footnotetext{
${ }^{72}$ Ver http://revistapiaui.estadao.com.br/materia/o-caseiro/.
} 
No caso da possível candidatura de Kassab pelo DEM, Serra, apesar de negar as negociações, conseguiu barrá-la. Fez isso porque pensava que a insistência do pefelista poderia criar um atrito na aliança entre PSDB e DEM, o que não seria bom para sua intenção de concorrer à presidência em 2010, e ainda tentando evitar a saída de Alckmin do PSDB, que havia recebido sondagens do PSB, graças à proximidade com o deputado e futuro secretário de Turismo do seu governo - Márcio França ${ }^{73}$, e também do PTB e PV. Já Aloysio Nunes não foi um grande obstáculo, pois decidiu, depois de conversas com aliados, concorrer ao Senado.

Em maio de 2010, ano em que o PSDB completou 15 anos à frente do governo de paulista, ocorreu o lançamento da pré-candidatura de Alckmin ao governo de São Paulo. Desde março o PSDB e o DEM estavam costurando a aliança que mantinham no estado há um bom tempo; nessa ocasião, o democrata Guilherme Afif Domingos foi apresentado como o candidato a vice na chapa encabeçada pelos tucanos.

Além do apoio do DEM, os tucanos contaram com o PMDB de Quércia, principal conciliador entre tucanos e peemedebistas. Antes do lançamento oficial da candidatura de Alckmin pelo PSDB, Quércia em evento em Araraquara já havia confirmado o nome do tucano e a aliança com o partido: "Como o PSDB demorou muito para lançar o Alckmin governador, nós estamos lançando. O PMDB que está lançando o nome dele"74. A aliança inédita entre tucanos e peemedebistas deveu-se, de um lado, ao interesse do PMDB de se fortalecer em São Paulo, e de outro, à intenção do PSDB de ter ao seu lado o partido que, junto com o DEM, havia apoiado a vitoriosa campanha do democrata Gilberto Kassab à prefeitura da capital em 2008.

Diante de todos os nomes cogitados pelo PT para o Poder Executivo paulista, Mercadante, em março de 2010, tinha como concorrente intrapartidário tão só Eduardo Suplicy. No dia $1^{\circ}$ de março, Suplicy cumpriu com a exigência do partido de que os précandidatos, para que tivessem a pré-candidatura convalidada, deveriam ter o apoio de pelo menos 2.970 assinaturas entre filiados do PT em São Paulo.

Após a desistência de Ciro Gomes em concorrer ao governo paulista, o então presidente Lula pediu que Mercadante fosse o candidato do PT, acreditando que a

\footnotetext{
${ }^{73}$ Ver http://www.tribunadonorte.com.br/noticia/alckmin-vetado-no-psb/34213 e Folha de S. Paulo em 15 de setembro de 2009, p. 9.

74 Ver

http://gazetaonline.globo.com/_conteudo/2010/04/626763quercia+lanca+candidatura+de+alckmin+em+araraquara.html.
} 
repetição da candidatura em São Paulo, que nunca havia acontecido desde então, traria vantagens ao partido na disputa. Mercadante, que tinha muitas chances de ser reeleito para o Senado, foi convencido por Lula e, na época, quando questionado sobre a desistência de concorrer para manter o mandato de senador, disse, referindo-se ao PT, que “(...) o melhor caminho, para nós, nunca foi o caminho mais fácil"75.

A decisão de Mercadante fez com que os demais nomes retirassem suas précandidaturas, exceto Suplicy, que recebeu o pedido unânime da direção estadual do partido para que abrisse mão espontaneamente da candidatura. Diante da pressão, Suplicy a retirou $^{76}$ e disse que não fazia sentido insistir em uma campanha “(...) em que todos os membros do partido recomendem que o candidato seja outro". Ainda no mês de março, dirigentes do PDT se reuniram com Mercadante e ofereceram apoio formal à sua candidatura pelo PT em troca da vaga de vice na chapa. O PT esperava formar uma aliança com o PSB. No entanto, com o lançamento da candidatura de Skaf, Mercadante foi oficializado como candidato, tendo como vice Antonio Clóvis Ferraz, do PDT.

Em 2010, o PSDB traçou a estratégia de priorizar as eleições para governador em quatro estados - incluindo São Paulo -, a fim de que a oposição sobrevivesse, caso houvesse a derrota do partido na eleição nacional para presidente. Tendo conseguido unificar o PSDB a seu favor e obtido o apoio de todos os diretórios do estado, o que não havia conseguido em 2006 e 2008, Alckmin se fortaleceu politicamente durante a campanha.

Em julho, pesquisa do Datafolha ${ }^{77}$ revelou que o candidato tucano tinha $49 \%$ das intenções de voto, contra $16 \%$ do rival Mercadante (PT), que concorrendo pela segunda vez consecutiva, era seu principal adversário. Pesquisa do Datafolha divulgada em maio, antes das campanhas ${ }^{78}$, indicava que a maioria dos simpatizantes do PSDB (51\%) dizia ser de direita. Diferentemente da pesquisa do Datafolha divulgada em 18 de dezembro de 2005, já mencionada anteriormente, no final de agosto de 2010, levantamento do mesmo instituto ${ }^{79}$ apontava que o candidato tucano era especialmente rejeitado entre aqueles que possuíam renda familiar mensal entre cinco e dez salários mínimos, ao tempo

\footnotetext{
$75 \quad$ Ver http://g1.globo.com/politica/noticia/2010/04/tese-de-repetir-candidato-reforcou-escolha-demercadante-em-sp.html.

${ }_{76}$ Ver pronunciamento de Eduardo Suplicy no Senado Federal sobre sua candidatura ao governo de São Paulo em https://www25.senado.leg.br/web/atividade/pronunciamentos/-/p/texto/383685.

${ }_{77}^{77}$ Pesquisa divulgada pela Folha de S. Paulo, Primeiro Caderno, 28 de julho de 2010, p. A11.

${ }^{78}$ Pesquisa divulgada pela Folha de S. Paulo, Primeiro Caderno, 30 de maio de 2010, p. 9.

${ }^{79}$ Pesquisa divulgada pela Folha de S. Paulo, Primeiro Caderno, 27 de agosto de 2010, p. 14.
} 
que liderava com vantagem no interior de São Paulo. Mercadante, que aparecia na segunda colocação, era, de acordo com a mesma pesquisa, rejeitado principalmente pelos eleitores mais ricos e entre aqueles com nível superior de escolaridade. Celso Russomanno (PP) aparecia na terceira posição com $7 \%$ das intenções de voto e Paulo Skaf (PSB) contava com $3 \%$.

Evitando na pré-campanha, quando já liderava com vantagem as pesquisas, o confronto de propostas com os adversários, Alckmin foi acusado pelo petista de utilizar a máquina pública paulista para se beneficiar; já Mercadante focava em questões de desenvolvimento que incluíam promessas de duplicar rodovias, melhorar o transporte público e reduzir pedágios, referindo-se à primeira gestão de Alckmin, que havia implantado diversas praças de pedágios. O psdebista privilegiava os números sobre segurança pública. Em sabatina realizada pela Folha de S. Paulo, o governador enfatizou o aumento no efetivo de policiais militares: "O fato é que reduzimos a criminalidade. Nós tínhamos 55 mil presos e hoje temos 165 mil presos. Nós enfrentamos o crime" ${ }^{\text {"80. }}$

Nos últimos dias antes das eleições, Mercadante conseguiu diminuir a diferença para Alckmin, devido, especialmente, aos eleitores com baixa escolaridade e aos que ganhavam entre dois e cinco salários mínimos, segundo as pesquisas. O tucano, de acordo com o Datafolha, venceria entre os eleitores mais ricos, mais escolarizados e mais velhos, de maneira que o envelhecimento da população foi considerado um fator favorável ao PSDB em São Paulo, ao passo que os mais jovens arriscariam votos menos tradicionais. Mesmo a diferença entre os dois sendo superior a vinte pontos percentuais, o candidato petista ainda acreditava no segundo turno.

Geraldo Alckmin, que encerrou a campanha sem apresentar seu programa de governo, foi eleito no primeiro turno com mais de 11 milhões de votos - 50,6\% das intenções de voto -, contra pouco mais de oito milhões de Mercadante $(35,2 \%)$, que teve uma votação melhor que a obtida em 2006. A volta de Alckmin ao governo representava o retorno de seus projetos bem como de secretários e membros de seu grupo. Ele teve ainda a Assembleia Legislativa recém-eleita favorável ao seu governo, com 52 deputados estaduais da base governista, 15 que poderiam negociar com o governo e 27 pertencentes à oposição. Entre os mais votados estavam os tucanos Bruno Covas, neto de Mário Covas, Pedro

\footnotetext{
${ }^{80}$ Folha de S. Paulo, Primeiro Caderno, 30 de julho de 2010, p. 10.
} 
Tobias, Fernando Capez e Barros Munhoz, além do petebista e alckmista Campos Machado.

\subsection{A quase unanimidade dos municípios na reeleição de Alckmin em 2014}

Em 2014, Alckmin tentou ser reeleito, e dessa vez teve como principais adversários candidatos do PT - novamente - e do PMDB. Os peemedebistas, devido ao grande incentivo do vice-presidente da República, Michel Temer (PMDB), lançaram a candidatura do empresário Paulo Skaf, que já havia concorrido ao governo de São Paulo em 2010, tendo ficado em quarto lugar, com pouco mais de 1 milhão de votos. No congresso regional do PMDB em São Paulo ocorrido em outubro de 2013, Skaf foi confirmado como pré-candidato, e Temer aproveitou a oportunidade para ratificar o lançamento de uma candidatura própria do partido em São Paulo, dizendo que "É muito importante para o nosso partido tentar chegar ao governo do estado. Assim como também é muito importante tentarmos eleger uma grande bancada de deputados federais e estaduais" ${ }^{\prime \prime}$.

As vantagens mencionadas pelo PMDB para lançar candidato próprio em São Paulo foram eleger mais deputados federais do que em 2010, quando apoiou o PSDB, e fortalecer o partido em São Paulo e suas lideranças, a exemplo de Michel Temer. Como principal desvantagem estava a dificuldade de Skaf para se colocar como uma alternativa à polarização recorrente estabelecida entre os candidatos do PSDB e do PT no estado.

Já Alexandre Padilha, que nunca havia participado de uma eleição e apenas ocupara o cargo de ministro, foi o petista escolhido pelo partido - na verdade por Lula para concorrer ao governo de São Paulo. A escolha de Padilha, feita em agosto de 2013, não era a primeira ideia do partido, nem de Lula, que o considerava "marinheiro de primeira viagem" e sem uma marca forte na gestão do Ministério da Saúde, diferente, por exemplo, de Fernando Haddad, ex-ministro da Educação, que foi eleito para a prefeitura da capital.

Padilha não era a preferência, mas foi a alternativa diante das recusas de Aloizio Mercadante e Marta Suplicy para concorrerem. Outra opção considerada pelo

\footnotetext{
${ }^{81}$ Folha de S. Paulo, Primeiro Caderno, 20 de outubro de 2013, p. 4.
} 
partido era o prefeito de São Bernardo, Luiz Marinho, que preferiu continuar na prefeitura para concluir seu mandato.

Mesmo sendo uma candidatura nova no estado, antes das eleições a equipe de Geraldo Alckmin demonstrou certa preocupação com Padilha, segundo reportagem de Fábio Zambeli na Folha de S. Paulo. Isso porque o petista, que já tinha sido titular da secretaria da presidência da República responsável por atender às reivindicações de municípios, conhecia de perto prefeitos e vereadores até de pequenos municípios do interior paulista, “(...) público para o qual intermediou farta liberação de recursos durante o governo Lula" ${ }^{\prime 2}$. Nesse sentido, os tucanos governistas temiam que Padilha concorresse de igual para igual com Alckmin pelos votos do interior.

A candidatura de Alckmin contou com a aliança recorde de 13 partidos, entre eles DEM, PPS e PSB. A aliança tucana com o PSB em São Paulo foi negociada ainda quando o então presidenciável Eduardo Campos era o presidente da sigla; Campos tinha interesse, mesmo com a resistência de sua vice Marina Silva (Rede), em alavancar sua candidatura no maior colégio eleitoral do país, aliando-se aos tucanos e ganhando com isso mais tempo no horário eleitoral gratuito. O resultado foi a indicação pelo PSB de Márcio França, principal articulador da aliança, como candidato a vice.

Já o apoio pelos tucanos do PRB, partido de Celso Russomanno, que foi candidato ao governo paulista em 2010, foi obtido pelos tucanos devido à nomeação de alguns indicados do ex-candidato para alguns órgãos paulistas, como o Procon. Além da aliança formal a tais partidos, Alckmin recebeu em setembro o apoio de 69 prefeituras comandadas por peemedebistas, das 92 existentes no estado ${ }^{83}$.

As conversas do PSDB com o PMDB iniciaram-se já em 2013. Entre outros interesses dos prefeitos que, em tese, deveriam ser apoiadores de Skaf, estava a garantia de verbas destinadas para o município, caso Alckmin fosse eleito. Certamente Alckmin se beneficiou do poder da máquina governamental para agregar o apoio das prefeituras, que funcionariam como uma rede de puxadores de votos.

Os principais adversários estavam coligados a partidos de menor representatividade no estado: os peemedebistas, a quatro partidos, entre os quais estavam o PDT, o PDS e o PP, partido de Paulo Maluf que apoiou o PMDB depois de também haver

\footnotetext{
${ }^{82}$ Folha de S. Paulo, Primeiro Caderno, 2 de agosto de 2013, p. 8.

Ver http://politica.estadao.com.br/noticias/eleicoes,prefeitos-do-pmdb-deixam-skaf-e-dao-apoio-aalckmin-imp-, 1568212.
} 
conversado com os tucanos e de ter declarado que apoiaria o candidato petista. O PDT, em junho de 2014, foi outro partido de desistiu de apoiar Padilha e declarou apoio aos peemedebistas em troca da indicação do candidato a vice na chapa, José Roberto Batochio, ex-deputado federal e ex-presidente da OAB-SP.

O PDS, partido de Gilberto Kassab, decidiu apoiar o PMDB depois da decisão tucana de se aproximar do PSB. O PT se aliou a PCdoB e PR, somente. A escolha de Padilha no PT fez com que alguns aliados se mostrassem resistentes a apoiar uma candidatura que seria, pelo menos de início, inexpressiva. O PR, por exemplo, tendo apoiado Serra em 2012 para a prefeitura paulistana, também negociou com os tucanos em 2013 e manifestou ao PT paulista que estava mais disposto a apoiar nomes mais experientes, como Mercadante ou Marta. O PR, no final das contas, manteve a aliança com o PT, o que fez com que o partido contasse com a ajuda do empresário Maurílio Biagi (PR), que, chegando a ser apontado como o candidato a vice na chapa petista, organizou uma série de encontros entre Padilha e empresários do agronegócio para motivar possíveis doações para a campanha. Com a recusa de Biagi em ser o vice de Padilha ${ }^{84}$, o PCdoB, na pessoa do deputado estadual Nivaldo Santana, ficou com a vaga.

Mesmo com as alianças firmadas, o governo paulista na véspera da eleição enfrentou várias dificuldades que poderiam prejudicar a reeleição; entre elas estavam as manifestações iniciadas em junho de 2013, que tiveram em São Paulo um reduto significativo e importante. Vários foram os protestos ocorridos contra o governador em meados desse ano, sendo um deles chamado "Ocupe Alckmin". Os manifestantes cobravam explicações sobre o escândalo do cartel dos trens, outro episódio que veio à tona na época, envolvendo as gestões do PSDB em São Paulo de 1999 a 2009.

Esse escândalo decorreu das acusações de que executivos de empresas estrangeiras, com a ajuda de servidores públicos, teriam fraudado licitações bilionárias do Metrô e da Companhia Paulista de Trens Metropolitanos (CPTM) no período citado. Em maio de 2013, a Siemens, empresa investigada, estabeleceu o compromisso de revelar informações sobre o caso $^{85}$ e apresentou documentos que apontavam para o aval do

\footnotetext{
84 Ver http://www.unica.com.br/noticia/21209732920313722805/maurilio-biagi-filho-decide-nao-ser-vicena-chapa-do-pt-em-sp/.

${ }_{85}$ Ver http://politica.estadao.com.br/blogs/fausto-macedo/promotoria-ja-pediu-dez-vezes-a-prisao-de-11executivos-do-cartel-de-trens-em-sp/.
} 
governo paulista em 2000 para a formação do conluio, o que motivou cartazes de manifestantes que diziam: "A Siemens já falou; e você, governador?”.

O governo paulista, nessa ocasião, alegou motivação política para as acusações e apontou o Conselho Administrativo de Defesa Econômica (CADE), órgão responsável pela investigação, como um "instrumento de polícia política" ${ }^{\text {"86 }}$ contra as gestões tucanas em São Paulo, em benefício da oposição. Geraldo Alckmin receava que, diante de tais acusações, seu governo fosse ligado a esquemas de corrupção em pleno período eleitoral.

O problema que mais poderia prejudicar, no entanto, a reeleição de Alckmin era a crise da água em todo o estado, que resultou em protestos diante da escassez e do racionamento imposto à população. Antes mesmo do início da campanha eleitoral, aliados de Alckmin consideravam o problema da água mais palpável pelo eleitor e, portanto, poderia interferir mais na decisão de em quem votar, do que as acusações relacionadas a ilegalidades no setor de transportes.

Durante a crise de abastecimento, o presidente estadual do PT-SP, Emídio de Souza, chegou a dizer que "Enquanto uma dona de casa de Guarulhos tem água um dia sim, dois não, Alckmin aumenta em $22 \%$ o consumo de seu palácio" ${ }^{27}$. Os adversários, como se esperava, utilizaram em seus programas eleitorais todos os problemas enfrentados pela gestão Alckmin a fim de confrontar o governo, inclusive questões de segurança, que sempre permearam as eleições paulistas.

Todavia, tais ataques não o pegaram desprevenido. Para minimizar os efeitos eleitorais negativos das denúncias de formação de cartel em licitações de trem e metrô no estado, Alckmin mencionou em propagandas ações de investigação dos desvios, objetivando, com isso, desarmar os ataques da oposição. Além disso, contando com uma boa estratégia de marketing, o governador evitou, em eventos, responder a perguntas de jornalistas e, durante sua campanha, não tratou diretamente do problema da água, que era o que mais lhe assombrava, até o penúltimo programa de $\mathrm{TV}^{88}$. Quando falava, relacionava o problema à "maior seca dos últimos 84 anos". Ademais, "em 2014, as campanhas publicitárias da Sabesp foram tímidas, e o logotipo do governo do estado, que acompanhava as peças, sumiu, numa tentativa de desvincular o Palácio da crise” ${ }^{\text {}}$.

\footnotetext{
${ }^{86}$ Folha de S. Paulo, Primeiro Caderno, 3 de agosto de 2013, p. 2.

${ }^{87}$ Folha de S. Paulo, Primeiro Caderno, 11 de abril de 2014, p. 4.

${ }^{88}$ DUAILIBI, Julia. "O paulista Ge-ral-do: Como Alckmin encarnou o homem comum e prolongou seu recorde no palácio, apesar da crise da água”. Revista Piauí, n. 99, dezembro 2014.

${ }^{89}$ Idem, p. 28.
} 
Alckmin fez questão de apontar a importância da experiência política para o exercício de um governo, utilizando-se da frase de que "ninguém vira governador do maior estado do Brasil da noite pro dia" ${ }^{90}$ para atacar indiretamente seus concorrentes. Além disso, recontou a história de como o PSDB com Covas assumiu São Paulo em 1994, citando a má gestão do PMDB e ligando o ex-governador Fleury Filho ao candidato Paulo Skaf; afirmou que o primeiro era o coordenador da campanha do pemedebista e que, portanto, Skaf não era sinônimo de uma nova política.

Somado a tudo isso, o governador valeu-se ainda da velha fórmula de mostrar aos eleitores que São Paulo é o estado que mais prende no Brasil. Nelson Biondi, marqueteiro de Alckmin nas últimas eleições, escolheu a estratégia de exaltar o tamanho da população carcerária paulista na campanha tucana, acreditando que a ideia "bandido bom é bandido morto" tem hoje "muito respaldo na sociedade", principalmente entre o eleitorado mais velho, que quer, acima de tudo, ordem.

Para minar de vez a candidatura de Padilha, Alckmin, valendo-se do currículo do petista, que tinha sido ministro da Saúde, utilizou pesquisas de percepção do eleitorado paulista a fim de mostrar que, de acordo com os eleitores, o problema da saúde pública no estado recaía mais sobre o governo federal e menos sobre o estadual. As mesmas pesquisas mostravam que o programa "Mais Médicos" "92, do governo federal, criado para conferir uma imagem positiva à gestão de Padilha na Saúde, suscitava dúvidas dos eleitores quanto à eficiência do trabalho de médicos estrangeiros.

Em contraposição, a grande aposta da campanha petista foi o ex-presidente Lula, que, assim como em outras campanhas, funcionou como o principal cabo eleitoral. Em um evento organizado em São Paulo para apresentar à militância Padilha como candidato, Lula chegou a dizer que "Esse estado é muito importante para ser governado

\footnotetext{
${ }^{90}$ Ver propaganda eleitoral em https://www.youtube.com/watch?v=afkCL4ThW34

9191 DUAILIBI, Julia. "O paulista Ge-ral-do: Como Alckmin encarnou o homem comum e prolongou seu recorde no palácio, apesar da crise da água”. Revista Piauí, n. 99, dezembro 2014, p. 22.

${ }^{92}$ O programa "Mais Médicos", criado em 2013 pelo governo federal em parceria com estados e municípios, tem como objetivo melhorar o atendimento dos usuários do Sistema Único de Saúde (SUS) a partir da contratação de médicos estrangeiros. Em defesa do programa, o então ministro da Saúde Alexandre Padilha disse em entrevista à revista Carta Capital (13/7/2013) que "Precisamos de mais médicos e mais perto da população. Isso exige enfrentamento imediato. (...) caso as vagas [do programa] não sejam preenchidas por brasileiros, o ministério vai fazer como outros países: atrair médicos estrangeiros para trabalhar exclusivamente na periferia das grandes cidades e nos municípios do interior". Ver http://www.cartacapital.com.br/saude/precisamos-de-mais-medicos-imediatamente-diz-padilha-2122.html.
} 
por passarinho que tem voo curto e bico muito grande. Esse estado já merece uma constelação", referindo-se aos respectivos símbolos dos partidos.

A fim de dar publicidade às ações de Padilha como ministro, o Ministério da Saúde fez um investimento significativo no "capital simbólico" do candidato petista, como diria Bourdieu, tendo um aumento de 19,7\% em 2013 nos gastos com propaganda. O PT também acreditava que a candidatura de Skaf pelo PMDB ajudaria a tirar mais votos de Alckmin, levando a disputa para o segundo turno, o que aconteceu em 2002, quando estavam no páreo três candidaturas competitivas: Alckmin (PSDB), Genoíno (PT) e Maluf (PPB). Mesmo que isso não acontecesse, os petistas já consideravam um grande passo o PMDB não ter se aliado formalmente ao PSDB, como ocorrera na eleição de 2010.

Pesquisa do Ibope realizada em julho de 2014 mostrou que Alckmin liderava a disputa com $50 \%$ das intenções de voto, seguido por Skaf $(11 \%)$ e Padilha $(5 \%)^{93}$. Em outubro essa ordem se confirmou. Alckmin venceu em primeiro turno com uma diferença de mais de 7 milhões de votos para o segundo colocado, Paulo Skaf (PMDB), conforme pode ser visto na tabela 5, abaixo, vencendo em 644 municípios dos 645 existentes. Ele obteve $62 \%$ dos votos nos municípios interioranos e 51\% na Grande São Paulo. Padilha, por quatro pontos percentuais a mais que Alckmin, venceu apenas em Hortolândia.

Um dia antes da eleição, o jornal Folha de S. Paulo previu que o governador seria reeleito já no primeiro turno, "ajudado sobretudo pelo voto interiorano e de eleitores pobres e sem escolaridade" 94 , o que foi parcialmente confirmado pela pesquisa estatística realizada na primeira parte deste trabalho.

Embora Padilha tenha feito várias viagens e caravanas ao interior do estado, visando quebrar a resistência do eleitor interiorano em relação ao PT e conquistar votos na região, ele não conseguiu se sobrepor à hegemonia de Alckmin. Enquanto Padilha teve o pior desempenho do PT desde 1994 com a candidatura de José Dirceu, Skaf fez com que o PMDB tivesse seu melhor desempenho em duas décadas.

\begin{tabular}{c|cc}
\multicolumn{3}{|c}{$\begin{array}{c}\text { Tabela 5 - Resultado da eleição em 2014 para } \\
\text { governador em São Paulo }\end{array}$} \\
\hline \multirow{2}{*}{ Candidatos } & \multicolumn{2}{|c}{ Votação geral } \\
\cline { 2 - 3 } & $\begin{array}{c}\text { Votos } \\
\text { nominais }\end{array}$ & $\%$ \\
\hline Geraldo Alckmin (PSDB) & $12.230 .807 \quad 57,31$
\end{tabular}

\footnotetext{
${ }^{93}$ Pesquisa publicada na Folha de S. Paulo, Primeiro Caderno, 31 de julho de 2014, p. 8.

${ }^{94}$ Folha de S. Paulo, Eleições 2014, 5 de outubro de 2014, p. 12.
} 


\begin{tabular}{l|cc} 
Paulo Skaf (PMDB) & 4.594 .708 & 21,53 \\
Alexandre Padilha (PT) & 3.888 .584 & 18,22 \\
Outros candidatos & 627.123 & 2,94 \\
Votos brancos e nulos & 4.395 .559 & 17,08 \\
\hline \multicolumn{2}{l}{ Fonte: Elaboração da autora a partir dos dados do TSE. }
\end{tabular}

Para alcançar tal resultado, Alckmin, que utilizou durante a campanha o slogan "É com trabalho sério que São Paulo avança", contou não só com sua rede de aliados, mas também com os erros e equívocos de seus adversários. Padilha, que por si só não era um candidato visível, associou sua imagem à de Lula num contexto em que o PT já não possuía o mesmo encanto de 2002. O partido, que havia conseguido transformar seu crescimento nacional na ascensão de seus candidatos em São Paulo, como aconteceu com Genoíno e Mercadante, não realizou o mesmo feito em 2014, devido ao seu envolvimento em escândalos de corrupção, o que reduziu o seu prestígio entre os eleitores.

Nessa eleição, o partido chegou até a contratar “militantes de aluguel” - prática não incomum entre os candidatos paulistas - para que fizessem figuração em caminhadas e panfletagem. Diante da dificuldade de Padilha, Lula chegou a cobrar publicamente do partido mais empenho em São Paulo: “O partido precisa voltar a ocupar as ruas desse país como sempre fizemos. O lugar do PT não é no gabinete; o lugar do PT é na rua, conversando com o povo, politizando a sociedade" 95 .

Paulo Skaf, embora houvesse concorrido ao governo paulista em 2010 pelo PSB, também não era um candidato visível, principalmente entre o eleitorado mais pobre. Sendo uma liderança empresarial, viu sua campanha tomar mais corpo quando, como presidente da FIESP, interferiu juridicamente para a anulação do aumento do IPTU na capital, aumento esse defendido pelo prefeito petista, Fernando Haddad ${ }^{96}$.

Mesmo ultrapassando Padilha, Skaf não conseguiu chegar nem perto da votação recebida por Alckmin: a diferença foi de mais de 7 milhões de votos. Um dos fatores que pode explicar a fácil reeleição de Alckmin em 2014 é que, comparado aos demais competidores, "ele é o mais conhecido e já foi eleito (...)”, como mencionou um eleitor entrevistado pela Folha.

\footnotetext{
${ }^{95}$ Idem.

${ }^{96}$ Ver http://g1.globo.com/sao-paulo/noticia/2013/12/skaf-compara-iptu-cpmf-haddad-diz-que-fiesp-querprejudicar-sp.html.
} 


\subsection{Alianças e eleições: a modelagem da disputa pelas elites políticas}

No decorrer da democracia brasileira, as organizações partidárias, seus candidatos e os eleitores se adaptaram a um ambiente político mais competitivo, o que certamente resultou na aplicação de um comportamento estratégico em ambos os lados. Os partidos e políticos estabeleceram estratégias baseadas no marketing eleitoral, na constituição de alianças que antes eram tidas como impossíveis e em trocas de favores com os votantes - a famosa política do toma lá, dá cá. Já os eleitores, que passaram mais de uma década sem eleger um presidente, governador ou prefeito democraticamente, graças à emergência do sufrágio universal puderam dar voz às suas preferências e, com o passar do tempo, optar, tendo em vista a avaliação daquilo que fez (ou não fez) o governo, ou manifestar apoio nas urnas ao partido ou candidato que mais lhes agradavam ou presenteavam.

Com o aumento do número de partidos e com as transformações ocorridas no mercado eleitoral, veio à tona o voto estratégico, pautado pela simpatia ou pela rejeição em relação às alternativas ofertadas pelas elites políticas. A estratégia nesse caso consiste em abandonar o lado mais fraco, ou seja, não votar no candidato/partido visto como sem chances, a fim de não desperdiçar o voto, depositando-o na alternativa que se considera menos prejudicial entre aquelas que ainda estão no páreo (PASQUINO, 2005).

Diante das infinitas motivações e estratégias dos atores que protagonizam o período eleitoral, a conexão entre candidatos, partidos e eleitores é evidente e fundamental para entender a dependência entre eles. Portanto, os papéis dos sistemas eleitoral e partidário, por se acharem entrelaçados, devem ser ponderados para a compreensão do que ocorre antes da eleição e durante ela, sabendo que a etapa pré-eleitoral tem grande peso no resultado final da competição. Segundo Pasquino (2005), a formação de um governo se apresenta como o resultado das dinâmicas que envolvem ambos os sistemas e, evidentemente, o voto dos eleitores.

O que une o sistema partidário ao eleitoral não é somente a exigência de ser filiado para ser eleito ou a criação de identidades políticas, mas também, e principalmente, as normas eleitorais que hoje, no Brasil, por darem autonomia aos partidos políticos nos critérios de escolha e regime de coligações, incentivam a definição de alianças políticas 
fundamentadas no comportamento office-seeking das organizações partidárias, isto é, na procura pela ocupação de cargos.

Conforme apontou Max Weber, os partidos políticos podem se basear fundamentalmente na "patronagem de cargos", visando ao arranjo de "cargos públicos para seu séquito, composto do aparato de funcionários e de propaganda do partido" (WEBER, 2014, p. 195). A inserção política dos partidos menores, menos visíveis na arena eleitoral, dá-se comumente pela aliança aos partidos maiores; aqueles esperam ser lembrados na repartição dos cargos e benesses, caso haja a vitória do aliado. Com isso, beneficiam-se também os partidos maiores, os quais buscam parceiros que os ajudem na formação de uma coligação que tenha chances reais de (re)conquistar o poder.

Há vários motivos para o aumento das alianças entre as organizações partidárias; entre eles está o de atenuar o impacto da crescente fragmentação do sistema partidário sobre a competição política, o que faz com que uma candidatura isolada tenha menos chances de vitória (CARREIRÃO, 2006). É certo que muitos partidos desistem ou nem cogitam encabeçar uma candidatura, para que possam propiciar apoio a outro partido que possua mais chances de se eleger, isto é, que tenha uma candidatura viável, de peso (LIMONGI; MESQUITA, 2011). Esse movimento interfere na composição do governo, pois em caso de vitória os cargos terão de ser repartidos entre os aliados.

Se a escolha dos aliados influencia o resultado eleitoral, pressupõe-se que essa escolha deva levar em consideração a distribuição das preferências eleitorais com relação aos partidos políticos ou, pelo menos, a capacidade que esses últimos e suas lideranças possuem para mobilizar tais preferências. É evidente que uma aliança com um partido que tenha maior inserção territorial e apoio popular é mais vantajosa que se aliar a um partido na situação contrária. O vínculo a um partido de peso é importante não só para se conquistar uma eleição majoritária como também para angariar aliados no Poder Legislativo, que, por formarem a base de sustentação do governo, serão fundamentais no decorrer do mandato mediante a negociação ou intermediação de demandas.

Assim, a estrutura da competição interfere no êxito eleitoral (LIMONGI; GUARNIERI, 2015) de uma candidatura. A construção de alianças, que integra o jogo político, é um dos pontos que iniciam a modelagem da disputa. Limongi e Mesquita (2011) apontam que o desenvolvimento da capacidade de mobilização do eleitorado depende da 
construção pelos partidos da sua estratégia eleitoral, que passa pelas alianças formadas na pré-campanha e pela distribuição de forças, caso haja um segundo turno.

A mobilização eleitoral não é feita somente via identidade e ideologia partidária, mas também, e talvez com mais efetividade, via atração de eleitores de partidos que pecam por não apresentar candidaturas viáveis e/ou por não serem flexíveis quanto à formação de alianças, visando preservar e manter pura a sua linha ideológica.

Nesse sentido, "na ausência de coligações eleitorais entre os partidos dos diferentes blocos, a coordenação fica a cargo dos eleitores" (LIMONGI; MESQUITA, 2011, 209), o que abre espaço para o voto estratégico citado anteriormente. Aderir a uma estratégia de mobilização menos ideológica e mais eleitoreira parece ser a escolha de parte significativa dos partidos. Carreirão aponta que “(...) a estratégia de lançar coligações com graus fraco ou médio de coerência ideológica, não apenas não é punida pelos eleitores, como tem um rendimento superior ao das coligações ideologicamente mais consistentes" (CARREIRÃO, 2006, p. 158).

\subsection{A importância dos aliados para as vitórias tucanas em São Paulo}

As eleições para o Executivo estadual paulista desde 1994 nunca tiveram menos de nove candidatos, coligados ou não, alcançando, em 2006, o maior número de concorrentes disputando o cargo: 17 candidatos. Certamente o elevado número de candidaturas representa a alta quantidade de partidos políticos registrados hoje no Brasil. No entanto, a competição político-eleitoral comumente ocorre centralizada em poucos partidos e candidatos, o que aponta para uma dinâmica eleitoral bipolar ou, no máximo, tripolar. Conforme ressalta Peres (2013), fazer parte de uma competição não significa ser competitivo.

Uma candidatura viável, isto é, aquela que é visível aos olhos dos eleitores e considerada por eles, depende de vários fatores e de circunstâncias que se colocam no meio político, não bastando para a vitória apenas estar na disputa. De 1980 até o início dos anos 90 a política paulista foi centrada no PMDB e no PDS, que mais tarde virou PPR, partido de Paulo Maluf. Em meados dos anos 90, a centralidade do PMDB passou para o PSDB, e a partir daí os tucanos tiveram, com raras exceções, o PT como principal adversário, especialmente a partir de 2002. 
O PSDB, em 1989, participou pela primeira vez de uma disputa eleitoral; concorreu à presidência da República, com Mário Covas, sem estar aliado a nenhuma outra força, assim como ocorreu no pleito estadual paulista em 1990. Foi a partir das eleições de 1994 que a competição eleitoral se estruturou de outra forma. As alianças feitas pelo PSDB desde sua primeira vitória para o governo de SP incluíram partidos que se localizam em sua maioria à direita e ao centro do espectro ideológico.

Celso Ricardo Roma (2000) atribui parte do sucesso eleitoral do PSDB nos âmbitos federal e estadual às mudanças nas estratégias de aliança a partir de 1994, o que gerou um cenário de competição política diferente do que havia ocorrido no pleito de 1990. Segundo Roma, o PSDB cresceu eleitoralmente e aumentou a conquista de mandatos quando passou a buscar aliados vistos mais à direita do espectro político. $\mathrm{O}$ autor cita que em 1990 os tucanos concorreram para o governo de 14 estados e venceram apenas no Ceará, com o apoio do PDT. Já em 1994 o PSDB, tendo como a maioria dos aliados partidos considerados de direita e de centro, elegeu seis governadores ${ }^{97}$.

Considerando especificamente as eleições para o governo de São Paulo em 1990, o psdebista Mário Covas não alcançou a vitória nem mesmo o segundo turno, ficando atrás dos candidatos do PDS (Paulo Maluf) e do PMDB (Luís Antônio Fleury Filho). Nessa ocasião, os tucanos estavam parcialmente isolados no estado, possuindo apenas o apoio informal do Partido Verde (PV), que, tendo o registro provisório negado pela Justiça Eleitoral nesse ano, foi impedido de participar legalmente das eleições lançando candidaturas ou apoiando outros partidos.

O único insucesso do PSDB na competição pelo governo paulista pode estar relacionado não só à escassez de aliados, mas também ao fato de que o partido ainda era recente e não tinha a seu favor uma conjuntura política que o favorecesse. O PMDB, que possuía grande visibilidade por ter sido o partido de oposição oficial ao regime militar, havia se consolidado em São Paulo desde o início dos anos 80, com a eleição em 1982 de André Franco Montoro, e Paulo Maluf, que já tinha sido governador de São Paulo durante a ditadura, era uma das principais lideranças populistas no estado.

\footnotetext{
${ }^{97}$ Para informações mais detalhadas e acesso à base de dados do autor, ver o trabalho completo "Política de alianças e desempenho eleitoral: um estudo sobre as estratégias de competição do PSDB, 1988-1998", disponível http://www.anpocs.org/portal/index.php?option=com docman \&task=doc view $\&$ gid=4784\&Itemid=357.
} 
Corroborando o pensamento de Roma, Limongi e Mesquita (2011) assinalam que tanto o sucesso de Mário Covas quanto o de Fernando Henrique Cardoso em 1994 estiveram diretamente ligados à ausência de competidores de peso à direita que encabeçassem uma chapa. Paulo Maluf, do então Partido Progressista Renovador (PPR), o único que talvez pudesse ameaçar a vitória de Covas, tendo em vista a derrocada do PMDB, não foi candidato e tampouco se empenhou em transferir sua força eleitoral para outro competidor.

Nessa eleição, o PDT foi o principal rival dos tucanos, alcançando inclusive o segundo turno. Covas, que já contava desde o primeiro turno com o apoio do PFL, conseguiu o apoio do PT - que tinha ficado na terceira colocação - e de outras legendas na segunda fase da disputa e se saiu vitorioso.

Em 1998, Maluf voltou a concorrer ao governo de São Paulo e liderou a disputa por quase toda a campanha. Covas, que concorreu à reeleição, não tinha a seu favor um contexto favorável, tendo em vista o aumento do desemprego e o corte de gastos realizado na sua gestão. Além disso, perdeu o apoio do PFL, que se aliou a Maluf. Numa campanha difícil, o tucano, novamente apoiado pelo PT no segundo turno, venceu Maluf com uma diferença de menos de 2 milhões de votos.

Já em 2002 certamente a vitória de Alckmin deveu-se à conquista pelo PSDB em São Paulo dos partidos que apoiaram Lula - presidente eleito - nacionalmente: PPS, PSB e parte do PDT. Com essa composição de forças, o PSDB conseguiu barrar ou pelo menos minimizar a influência de Lula e isolar José Genoíno politicamente. A estratégia eleitoral de Alckmin no segundo turno também abarcou a comparação do seu governo com a gestão de Marta Suplicy (PT) na prefeitura da cidade de São Paulo, visando abordar as promessas não cumpridas pelos petistas e aquilo que não deve ser feito. Os tucanos paulistas também disputaram com o PT os eleitores que haviam votado em Maluf no primeiro turno, tendo o cuidado, no entanto, de se desvincular do apoio dele propriamente. Para tanto, os psdebistas buscaram o apoio de prefeitos e deputados estaduais pepebistas que não faziam oposição à Alckmin na Assembleia.

A vitória de José Serra para a prefeitura da capital paulista em 2004 teve duas consequências. Em primeiro lugar, reafirmou a liderança de Alckmin no estado, de modo que ele, além de emprestar sua imagem a Serra, auxiliou no delineamento de estratégias e discursos. Ademais, consolidou a aliança entre PSDB e PFL, que eram os principais 
partidos de oposição no Brasil. Com isso, nas eleições estaduais de 2006, o PFL novamente firmou sua aliança com o PSDB, que agora teria em SP José Serra como candidato a governador.

Em 2005, os pefelistas, que cogitavam lançar a candidatura de César Maia, então prefeito do Rio de Janeiro, para a presidência da República, abriram mão de encabeçar a disputa depois de fecharem um acordo com Serra, que até aquele momento era dado como o candidato tucano ao cargo ${ }^{98}$. Não contavam, no entanto, com a insistência de Alckmin em disputar a vaga do partido com Serra. Após uma série de manobras e conversas políticas, Alckmin acabou como candidato ao Planalto e Serra concorreu, a contragosto, ao governo de São Paulo. No entanto, nenhum dos tucanos perdeu o apoio do PFL nessas eleições.

Nas eleições de 2010, o PSDB conseguiu agregar em São Paulo o apoio do DEM, ex-PFL, e do PMDB, antiga força política no estado. O interesse da aliança entre peemedebistas e tucanos era mútuo: os primeiros queriam voltar a ganhar espaço político no estado e os últimos queriam refazer no âmbito estadual a aliança que dois anos antes tinha culminado na vitória de Gilberto Kassab (DEM) para a prefeitura de SP. Embora Alckmin e o PSDB tenham perdido a aliança formal ao PMDB nas eleições de 2014, tendo em vista a decisão do partido em lançar candidato próprio, eles contaram com o apoio dos prefeitos peemedebistas, que comandavam cerca de noventa municípios em São Paulo.

Alckmin em suas gestões sempre se preocupou em angariar aliados. Em maio de 2013, visando ao apoio nas eleições de 2014, ele deu ao Partido Republicano Brasileiro (PRB) o comando da Secretaria de Desenvolvimento Social; diante da reclamação de alguns tucanos sobre a perda de assessores na pasta, afirmou ser necessário que eles compreendessem a importância das alianças ${ }^{99}$.

Mesmo que as vitórias tucanas para o governo paulista hajam sido acompanhadas pelo crescimento de alianças que tinham como principais forças partidos de centro-direita, partidos considerados de centro-esquerda, mais especificamente, o Partido Popular Socialista (PPS) e o Partido Socialista Brasileiro (PSB), começaram a aparecer na coligação do PSDB paulista nas últimas eleições. O PPS se aliou aos tucanos desde 2006, e o PSB se aliou em 2014, devido a um acordo firmado entre o presidenciável Eduardo Campos e Alckmin.

\footnotetext{
${ }^{98}$ Ver http://congressoemfoco.uol.com.br/noticias/serra-fecha-acordo-com-pfl-para-2006/.

${ }^{99}$ Folha de S. Paulo, Primeiro Caderno, 5 de setembro de 2013, p. 4.
} 
Antes da aliança com os tucanos, o PSB em SP vinha, sem sucesso, tentando emplacar candidato próprio ao governo, como ocorreu nas eleições de 2002, 2006 e 2010. Na década de 90, PPS e PSB chegaram a apoiar os candidatos petistas que concorriam ao governo paulista. Em 1998 o PT perdeu o apoio do PSB, que se coligou ao PDT, e a partir de 2002 em diante não foi mais apoiado por nenhum deles.

Outro fator de sucesso dos tucanos em termos de aliança no estado de São Paulo é o apoio que o governo detém na Assembleia Legislativa (ALESP), a qual tem funcionado como extensão das vontades do Poder Executivo paulista. Praticamente todos os projetos importantes para os governadores tucanos foram aprovados sem resistência pelos deputados, que também quase não abriram Comissões Parlamentares de Inquérito contra a gestão Alckmin. Foram raras as insubordinações dos deputados contra o Executivo estadual durante as administrações psdebistas, não só devido à conivência dos parlamentares oposicionistas, como também graças às artimanhas do governo e de sua base aliada.

Segundo relato do ex-prefeito de Guarulhos, Elói Pietá, que foi líder do PT na Câmara Legislativa entre 1999 e 2002, naquela época "não se conseguia fiscalizar a fundo a administração estadual e não havia diálogo do governo paulista com a oposição. Não se conseguia instalar CPI nenhuma ao menos que a base aliada quisesse". Desde o primeiro mandato de Mário Covas, a base parlamentar aliada ao governo é maior que a da oposição, como mostra a tabela abaixo (tabela 6).

\begin{tabular}{c|cc}
\multicolumn{2}{c}{ Tabela 6 - Bancadas eleitas na Assembleia Legislativa de São } \\
Paulo (1994-2014)
\end{tabular}


Fonte: elaboração da autora a partir de dados da liderança do PT e dos arquivos históricos da Assembleia Legislativa.

Na legislatura iniciada em 2011, a oposição na Câmara Legislativa conseguiu instalar apenas a CPI dos Pedágios, para apurar irregularidades da gestão estadual na área. Ainda assim o PSDB conseguiu emplacar Bruno Covas como presidente desta. O PT tentou, sem sucesso, coletar assinaturas para a abertura de uma CPI para o chamado "escândalo das emendas", a fim de investigar a liberação de recursos pelo governo tucano para deputados acima do teto estipulado. Dados divulgados pela Secretaria de Fazenda do estado mostram que dos 97 deputados contemplados com verbas do governo estadual, 78 conseguiram a liberação de valores acima da cota de R \$ 2 milhões. Entre os beneficiados estavam tanto deputados tucanos quanto petistas.

No entanto, a bancada de deputados estaduais do PSDB apadrinhou quase um terço (cerca de 181 milhões de reais) de todo o montante liberado pelo governo paulista em emendas parlamentares ao Orçamento desde 2007 (615 milhões), incluindo as gestões de Serra e Alckmin. PT e DEM, que possuíam em 2011 as duas maiores bancadas depois do PSDB, apadrinhavam 105 e 75 milhões de reais, respectivamente. Bruno Covas, deputado tucano mais votado nas eleições de 2010, foi o relator do Orçamento do Estado para os exercícios de 2010 e 2011.

Tabela 7 - Valor do total de emendas liberadas pelo governo de São Paulo entre 2007

\begin{tabular}{c|cccc}
\multicolumn{5}{c}{ e outubro de 2011 por partido (em milhões de reais) } \\
Partido & $\begin{array}{c}\text { Valor total de } \\
\text { emendas recebidas } \\
\text { 2007 a 2011 - (em } \\
\text { milhões de reais) }\end{array}$ & $\begin{array}{c}\text { Bancada } \\
\text { (deputados } \\
\text { eleitos em } \\
\text { 2006) }\end{array}$ & $\begin{array}{c}\text { Bancada } \\
\text { (deputados } \\
\text { eleitos em } \\
\text { 2010) }\end{array}$ & $\begin{array}{c}\text { Apoio ao } \\
\text { governo } \\
\text { Alckmin (em } \\
\text { 2011) }\end{array}$ \\
\hline PSDB & 181,3 & 23 & 22 & Sim \\
DEM & 75,7 & 12 & 7 & Sim \\
PV & 37,8 & 8 & 8 & Sim \\
PSB & 34,5 & 4 & 6 & Sim \\
PTB & 33,1 & 4 & 4 & Sim \\
PPS & 33 & 5 & 4 & Sim \\
PRB & 14,9 & $*$ & 2 & Sim \\
PSC & 13,7 & 2 & 1 & Sim \\
PP & 13 & 2 & 1 & Sim \\
PR & 4 & $*$ & 1 & Sim \\
\hline Total/Base do & 441 & 60 & 56 & Sim \\
governo & 105,3 & 20 & 24 & Não \\
\hline PT & 24 & 4 & 5 & Não \\
PMDB & & & &
\end{tabular}




\begin{tabular}{l|cccc} 
PDT & 20,5 & 5 & 3 & Não \\
PSD & 12,7 & $*$ & 3 & Não \\
PSOL & 7,9 & 2 & 1 & Não \\
PCdoB & 2,5 & $*$ & 2 & Não \\
\hline Total/Oposição & 172,9 & 31 & 38 & Não \\
ao governo & & & \\
\hline Fonte: elaboração da autora a partir dos dados divulgados pela Secretaria de Fazenda do estado de \\
São Paulo e pelo TSE. \\
* Partidos que não tiveram deputados eleitos em 2006.
\end{tabular}

\section{Gráfico 1 - Porcentagens do valor total de emendas (em R\$) destinadas à base do governo e à oposição na Assembleia Legislativa de SP entre 2007 e 2011}

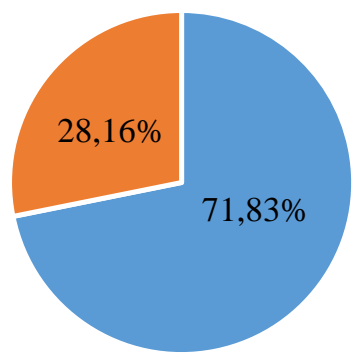

-\% do valor total recebida pela base do governo

- \% do valor total recebida pela oposição

Em 2014, a bancada de oposição ao governo Alckmin, formada por PT, PCdoB e PSOL, foi a menor desde 1998, com a eleição de apenas 18 parlamentares, número que correspondeu a pouco mais da metade do total necessário para a abertura de uma CPI. O PT foi o partido que mais contribuiu para tal queda, já que nessa eleição perdeu oito cadeiras na Casa Legislativa. Era evidente que a rejeição ao partido em São Paulo tinha afetado não só a eleição majoritária, como também a proporcional.

Sem número suficiente para abrir uma CPI, a oposição convocou desde meados de 2013 uma série de autoridades, empresários e consultores para prestar depoimento sobre as acusações de formação de cartel em licitações do metrô e da CPTM durante as gestões tucanas em São Paulo. Os requerimentos apresentados solicitavam a convocação de 26 pessoas. Dessas, somente três foram ouvidas na Assembleia Legislativa.

Segundo informações de reportagem de Paulo Gama publicada na Folha de S. Paulo, "As comissões em que os pedidos foram feitos - de Transportes e Infraestrutura, ambas com maioria governista - adiaram a análise de vários pedidos indefinidamente, rejeitaram outros e ainda transformaram convocações em convites, o que desobriga o 
convidado de comparecer" ${ }^{\prime 100}$. A bancada governista se defendeu das acusações de barrar na Assembleia as investigações sobre o cartel dizendo que a oposição tinha feito pedidos “eleitoreiros", que não passavam de "politicagem".

Diante do exposto, não se pode descartar a relevância das alianças eleitorais e daquelas firmadas durante o mandato tanto para as vitórias de Alckmin quanto para as de Covas e Serra. Em termos de alianças, pode-se dizer que o PSDB se fortaleceu eleitoralmente em São Paulo por dois motivos: i) reuniu em torno de si o PFL e demais partidos e lideranças que tinham ou ainda têm expressão no estado e/ou nacionalmente; ii) deu atenção não só às alianças para a eleição majoritária, como também para as eleições proporcionais, buscando ampliar a base governista na Câmara Legislativa.

Em São Paulo, a coligação entre tucanos e PFL, hoje Democratas, ocorre desde 1994. O PFL, durante os anos 90, tinha uma grande força política no âmbito nacional, pois possuía redutos eleitorais significativos principalmente na região Nordeste. Tendo isso em vista, os tucanos, a fim de alavancar a candidatura de Fernando Henrique Cardoso em 1994, firmaram aliança com o PFL, a qual se transpôs para alguns estados, incluindo São Paulo. A coligação com os pefelistas só não resultou em sucesso eleitoral para Paulo Maluf, que teve o apoio do partido em 1986. De lá pra cá não apenas o PSDB teve êxito eleitoral com o PFL, como também o PMDB, aliado a ele, saiu-se vitorioso em 1990.

Acredita-se que a aliança com o DEM beneficiou os tucanos nas últimas eleições na medida em que fortaleceu suas candidaturas no município, já que, assim como o PSDB, o DEM tem uma estrutura partidária bastante organizada no estado ${ }^{101}$, possuindo diretórios ou comissões provisórias em todas as cidades (BRAGA, 2008). O PSDB, só até 2005, possuía 615 diretórios municipais, segundo dados organizados por Braga. Em contraposição, o PT tinha 299 em todo o estado.

Entende-se que o sucesso eleitoral do PSDB em São Paulo também está relacionado à governabilidade obtida pelo partido e seus candidatos no decorrer dos mandatos, tendo em vista o tamanho da bancada aliada na Câmara Legislativa no estado. Os projetos e demandas advindas do Poder Executivo são, com raríssimas exceções,

\footnotetext{
${ }^{100}$ Folha de S. Paulo, Primeiro Caderno, 23 de dezembro de 2013, p. 4.

${ }^{101}$ Segundo pesquisa realizada por Maria do Socorro Braga (2008), a estruturação do PFL paulista tem como responsáveis o ex-governador de SP, Claudio Lembo, e o ex-prefeito de SP, Gilberto Kassab. A autora afirma que o objetivo de tal estruturação do PFL no estado foi "disputar, com o enfraquecido PP [Partido Progressista], o eleitorado conservador" (BRAGA, 2008, p. 462).
} 
aprovados pelos deputados - incluindo os de oposição -, que, em contrapartida, contam com a liberação de verbas para aplicação em seus redutos eleitorais.

Quanto à fiscalização do governo do estado, comumente as Comissões Parlamentares de Inquérito para a investigação de possíveis irregularidades são barradas ou direcionadas pela base governista, o que certamente protege o governador de possíveis escândalos ou acusações. 


\section{CAPÍTULO 3 - A IMPORTÂNCIA DA IMAGEM DE ALCKMIN PARA ALIADOS E ELEITORES}

\subsection{A centralidade da imagem do candidato nas eleições e suas causas}

Embora diversos estudos mencionem a importância dos partidos na arena eleitoral e encontrem dados que corroboram isso, o debate na literatura ainda é grande acerca da preponderância da figura do candidato sobre o partido. David Samuels denomina os sistemas eleitorais que contribuem para uma política eleitoral individualista de "centrados no candidato" (SAMUELS, 1997). Os políticos, ao tentarem se diferenciar dos demais concorrentes, fazem uma campanha eleitoral focada em sua autoimagem, o que contribui para que o voto dos eleitores constitua-se como uma forma de manifestar apoio pessoal a um candidato, e não ao partido (SAMUELS, 1997).

A centralidade no candidato pode ser ampliada também devido a fatores externos às regras dos sistemas eleitorais. Marcello Baquero relaciona o perfil do eleitor personalista à desconfiança e à descrença dos cidadãos nas instituições políticas e na política em geral (BAQUERO, 2000).

Ana Maria Belchior (2015), ao comparar os níveis de confiança em três instituições políticas - os governos, os partidos políticos e os parlamentos nacionais - em 52 países entre 2010 e 2014, conclui que das três instituições analisadas, as organizações partidárias são as que possuem menor apoio na totalidade dos países observados. Segundo Belchior (2015, p. 64): “(...) o desgaste das instituições das democracias liberais, os desaires econômicos, os escândalos políticos e demais problemas de eficiência governativa e de falta de transparência terão estado na origem do declínio e dos atuais baixos níveis de confiança política", situação que certamente confere aos partidos uma imagem negativa.

Mesmo que os políticos sejam também afetados por essa onda pessimista, a imagem, a atitude e/ou o carisma salvam alguns, enquanto os partidos são vistos como agrupamentos compostos por pessoas que querem apenas se autobeneficiar e alcançar o poder. É nesse sentido que os eleitores muitas vezes descolam o candidato do partido e nutrem por esses últimos sentimentos antipartidários.

Além disso, o grande alcance dos meios de comunicação torna próxima e direta a relação entre eleitor e candidato. Como aponta o teórico da comunicação Herbert 
Marshall McLuhan em entrevista ao programa australiano Monday Conference ${ }^{102}$, "um dos efeitos peculiares da mídia na política é que os partidos e políticas se tornam desimportantes e a imagem de um político ganha uma tremenda nova importância”. Nesse caso, os partidos deixam de funcionar como as principais instâncias de intermediação entre aqueles que estão na esfera social e os que estão na esfera política - não só por causa do destaque do candidato, mas também por conta do surgimento de novas organizações que se inserem na sociedade para representar interesses, como as organizações não governamentais, por exemplo -, o que explica a decadência do papel das identidades partidárias na decisão do voto (MANIN, 1995).

Sabendo ainda que os interesses dos eleitores podem estar agregados seja por linhas individuais, território ou classe, o candidato eleito, ao ter nas mãos os recursos a serem por ele alocados, pode escolher que grupos tratar como clientelas e, com isso, sua centralidade se baseia nas negociações em torno da alocação de benefícios políticos, financeiros, materiais, etc., conforme aponta o modelo distributivista (CARVALHO, 2003). O fruto eleitoral disso são escolhas personalistas, que fazem surgir um "mercado de votos" (ROCHA \& BARBOSA, 2008).

Segundo Barry Ames, “Os políticos não se sustentam como tais cuidando da prosperidade de suas regiões e da provisão de bens públicos, mas distribuindo verbas, serviços e empregos a indivíduos" (AMES, 2003, p. 42). Nesse sentido, a ligação entre políticos e eleitores baseia-se numa relação estratégica que transcende a representação dos interesses sociais, de maneira que esses elos tendem a ser mais individuais do que institucionais.

Em contraponto a essa perspectiva, Marcos Bezerra aponta que o político mantém relações mais intensas com as regiões e os municípios onde a sua votação foi mais expressiva, ou seja, as localidades que formam suas bases eleitorais (BEZERRA, 1999). Essas regiões, segundo o autor, são visitadas com mais frequência e recebem maior quantidade de recursos, o que pode contribuir para a manutenção e ampliação desses redutos eleitorais em benefício do governante. Assim, o voto envolveria um elemento retrospectivo de avaliação dos que estão no poder (NICOLAU, 2006).

No entanto, se se considera a relação entre Alckmin e suas bases eleitorais, analisada posteriormente, ver-se-á, pelo menos em termos estatísticos, que não há em São

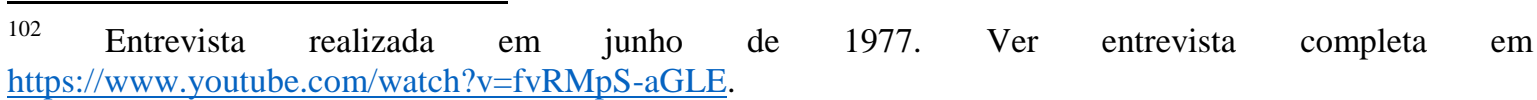


Paulo um padrão de voto regional que contribua significativamente para o êxito eleitoral do tucano. Isso, porém, não significa dizer que os eleitores do interior do estado e as articulações construídas por Alckmin com as autoridades municipais não sejam importantes para a sua votação, conforme já discutido. No entanto, dada a baixa relevância dos indicadores socioeconômicos e do grau de agregação das bases eleitorais para explicar o voto em Geraldo Alckmin no estado, acredita-se que a sua imagem contribui, conjugada com outros fatores, positivamente para o seu ganho de votos em face de seus adversários.

\subsection{Quem é o político Geraldo Alckmin? O bom moço metódico e paciente}

Alckmin. O sobrenome não tem uma origem definida: alguns dizem que vem do aramaico al-kemyn, que significa "o químico"; outros, que tem raiz na palavra árabe alkimya, significando "alquimia", protociência praticada na Idade Média, antecessora da química.

Geraldo, atual governador de São Paulo, não é o único Alckmin que ficou conhecido na política brasileira. Seu tio-avô, o político mineiro José Maria Alckmin (19011974), é uma referência do folclore político nacional. Foi um dos fundadores do Partido Social Democrático (PSD), além de ter sido deputado federal, ministro da Fazenda de Juscelino Kubitschek (1956-1958) e vice-presidente da República no governo de Castelo Branco (1964-1967), tendo combatido o governo de Jânio Quadros.

Geraldo também é sobrinho de José Geraldo Rodrigues de Alckmin (19151978), ex-ministro do Supremo Tribunal Federal (STF), nomeado em 1972, durante a ditadura militar, pelo então presidente Emílio Médici. Outros irmãos de seu pai foram eleitos prefeito e vereador em cidades do interior paulista pela União Democrática Nacional (UDN), partido criado em 1945 em oposição a Getúlio Vargas.

O próprio pai, Geraldo José, foi chefe de gabinete da Secretaria de Agricultura no governo Jânio Quadros. Parece, então, que Geraldo tem no seu sangue o talento ou a aptidão para a vida pública, embora afirme que nunca teve "pretensão de fazer política".

Nascido no município paulista de Pindamonhangaba em 1952, Geraldo Alckmin, médico anestesista, deve grande parte de sua ascensão política a Mário Covas. Na verdade, não há como falar de Alckmin sem falar em Covas. Assim como Alckmin teve Covas como padrinho político, esse último foi levado à política por Jânio Quadros. Com o 
apoio de Quadros, Covas disputou, sem sucesso, sua primeira eleição, em 1961, para a prefeitura de Santos, sua cidade natal. Janista, Covas adotou na época a vassoura como símbolo de sua campanha. Aos 32 anos, elegeu-se para seu primeiro cargo público, o de deputado federal pelo Partido Social Trabalhista (PST). Após ter seus direitos políticos cassados na ditadura, Covas retornou à política em 1979 e foi indicado por Franco Montoro para prefeito da cidade de São Paulo em 1983, tendo como sucessor Jânio Quadros. Como se vê, Alckmin compõe uma lista de nomes importantes na política paulista e herdou direta e indiretamente o legado político construído por figuras da estatura de Covas e Jânio.

Tendo raízes políticas na família, mas optando por caminhos diferentes de seu tio-avô, Geraldo Alckmin, semelhantemente a Covas, iniciou na política ainda jovem. Sua vida pública começou aos 19 anos quando, filiado ao antigo Movimento Democrático Brasileiro (MDB), foi eleito vereador em Pindamonhangaba no ano de 1972, com uma votação recorde. Logo em seguida foi eleito prefeito da mesma cidade. Tornou-se ainda deputado estadual e deputado federal.

Quando deputado estadual, no governo Franco Montoro (1983-1987), foi vicelíder do PMDB na Assembleia Legislativa. Já no Congresso Constituinte, aderiu ao grupo do então senador pelo PMDB e futuro padrinho político, Mário Covas. Nesse período, teve opiniões políticas contraditórias. Propôs a adoção do sistema parlamentarista, votou a favor do direito de greve e da reforma agrária e defendeu um mandato de quatro anos para o então presidente da República, José Sarney. Ao mesmo tempo, votou contra a redução da jornada de trabalho para quarenta horas semanais, contra a estabilidade no emprego, contra o tabelamento dos juros e contra a licença paternidade. Na avaliação do Departamento Intersindical de Assuntos Parlamentares (DIAP), que atribuiu nota de zero a dez aos parlamentares tendo em vista os pontos constitucionais classificados como de interesse dos trabalhadores, obteve média sete ${ }^{103}$.

Em 1988, seguindo Covas, fundou o PSDB. Seu nome consta em sétimo lugar entre as assinaturas presentes no livro de fundação do partido. Foi reeleito deputado em 1990 e, no segundo mandato na Câmara Federal, foi autor do projeto que originou o Código de Defesa do Consumidor e relator do projeto da lei de benefícios da previdência. Em agosto de 1991, tornou-se presidente do PSDB paulista, derrotando a deputada Zulaiê

\footnotetext{
${ }^{103}$ A avaliação máxima era atribuída aos parlamentares que votaram a favor em todos os pontos tidos como de interesse dos trabalhadores.
} 
Cobra; Sérgio Motta, candidato patrocinado pelo então senador Fernando Henrique Cardoso, desistiu da disputa antes da votação.

Como presidente estadual de seu partido em São Paulo (1991-1994), Alckmin começou a mostrar seu talento para canalizar aliados - qualidade política que Covas também possuía - e fundou diretórios. Realizando um trabalho de formiguinha, iniciou a construção de um leque de apoios que se mantém até hoje. Já naquela época, ele percorria todo o estado visando organizar as bases do PSDB, trabalho que o fortaleceu politicamente no interior e chamou a atenção de Covas.

Não foi à toa a escolha de Alckmin como candidato a vice-governador na chapa de Covas, embora a cúpula psdebista preferisse o economista e secretário da pasta de Emprego e Relações do Trabalho de SP, Walter Barelli. O próprio Covas tinha simpatia por Barelli, mas, tentando conciliar o partido em torno de um nome, organizou em seu apartamento uma votação com alguns dos deputados tucanos e o resultado foi favorável a Alckmin.

O vereador Mário Covas Neto, o Zuzinha, filho de Covas, lembrou em entrevista à jornalista Julia Duailibi que os tucanos "tinham que escolher um candidato que fosse palatável para o Covas, mas que também fosse para o Montoro, o Fernando Henrique e o Serra. O Geraldo era essa pessoa" ${ }^{104}$, pois era o "elemento neutro", tanto pelo seu bom relacionamento com todos os diretórios e alas do partido quanto por não incomodar ninguém.

Alckmin, graças à sua discrição, lealdade e honradez, qualidades atribuídas a ele por Covas, conquistou a confiança desse. Zuzinha lembra que Alckmin “(...) teve [como candidato a vice-governador] uma atitude absolutamente colaborativa, e isso foi conquistando o meu pai" ${ }^{\text {"105 }}$. Na disputa no segundo turno contra o candidato pedetista Francisco Rossi, foi ele quem negociou o apoio do PT e de Paulo Maluf à candidatura tucana.

Alckmin, quando presidia o PSDB paulista, já demonstrava seu jeito prudente para fazer política. Em 1994, Mário Covas era pré-candidato do PSDB ao governo paulista, todavia Alckmin sabia que José Serra também tinha intenções de disputar o governo. Tendo isso em vista, não assinou uma lista em que Covas solicitou que alguns deputados

\footnotetext{
104 “'O paulista Ge-ral-do” por Julia Duailibi. Revista Piauí, n. 99, ano 8, 2014, dezembro, p. 23. 105 Idem.
} 
recolhessem assinaturas de apoio a seu nome, alegando, para tanto, que como presidente do PSDB em São Paulo não poderia apoiar nenhum dos dois pré-candidatos.

Dois anos após a vitória em 1994, Alckmin assumiu a presidência do Programa Estadual de Desestatização (PED). Devido à grave crise financeira do estado, o governo estava cheio de dívidas e impedido de contrair empréstimos. O PED era um programa complexo que tinha por objetivo privatizar empresas estatais, além de conceder trechos de rodovias e ferrovias à iniciativa privada, com a finalidade de assegurar o equilíbrio das contas públicas e promover uma profunda reorganização de São Paulo.

Na época, o PED foi o único projeto estadual que satisfez todas as metas de privatização estabelecidas pelo governo federal. O programa foi concluído em 2000 e retomado em 2005, no primeiro mandato de Alckmin como governador. Segundo a Secretaria da Fazenda de SP, entre 1997 e 2005 a receita obtida com o programa foi de aproximadamente 26 bilhões de reais ${ }^{106}$.

Em 1998, Alckmin sentiu pela primeira vez o gosto de ocupar a cadeira de governador, tendo substituído Covas, que se licenciou do cargo para dedicar-se à campanha de reeleição. Sendo novamente reeleito vice-governador, ele destacou-se na campanha devido à articulação política que fez a favor do governo principalmente no interior paulista, nas regiões do Vale do Paraíba e no litoral norte.

Em 2000, Covas resolveu que era hora de dar peso político a Alckmin e o indicou para concorrer pelo PSDB à prefeitura da cidade de São Paulo. Na campanha, foi apresentado como um político com a cabeça no lugar. Porém, sendo mais visível no interior do estado do que na capital, o apoio de Covas como cabo eleitoral não foi suficiente ante as forças petista e malufista no município, e Alckmin foi derrotado no primeiro turno, ficando em terceiro lugar com 17,21\%, atrás de Paulo Maluf por uma diferença de pouco mais de 7.600 votos.

Voltou a assumir o posto de governador no lugar de Covas quando este se afastou por questões de saúde em 2001. Quando Alckmin assumiu pela segunda vez o cargo, colou à sua imagem características de correção e lealdade atribuídas a Covas, e até hoje o cita em campanhas e discursos como o "saudoso" Covas. A confiança dele em Alckmin era evidente. Covas sabia que seu pupilo não tomaria nenhuma decisão sem antes consultá-lo, e na reunião em que comunicou sua licença do governo disse: “O Geraldo é o

\footnotetext{
106 Para mais detalhes das medidas fiscais tomadas a partir de 1994 em São Paulo, ver
} http://www.fazenda.sp.gov.br/ajustes/. 
homem certo na hora certa". Era chegada a hora de Alckmin retribuir o empenho tenaz de Covas para transformá-lo em seu herdeiro direto no PSDB e na política do principal estado do país.

Diga-se de passagem, essa foi a grande ação que Covas poderia fazer por Alckmin no mundo político. Afinal, sendo os políticos também, e tão mais, mordidos pelo bicho da vaidade humana, sabe-se que geralmente notáveis figuras resistem a eleger ou sequer colaborar com a eleição de outros grandes personagens para lhes suceder. Em março de 2001, "Geraldinho", como era chamado por Covas, assumiu, com a morte de seu padrinho político, em definitivo o governo, embora isso não tenha agradado alguns tucanos que o achavam um "político menor".

Se Covas tinha a fama de ser turrão, Alckmin é a antítese disso, sendo conhecido por ter um estilo silencioso e conciliador. Zuzinha diz que Alckmin é conhecido por seu estilo “(...) meio mineiro, que evita polêmicas, bola dividida"107. Sempre prudente, desconversou em 2002 quando lhe perguntavam se assumiria definitivamente no lugar de Covas. O mesmo fez em 2005, quando era dado como virtual candidato do PSDB à presidência da República: “Cada coisa tem seu tempo. Eleição é só ano que vem. (...) O meu dever é fazer um bom trabalho no estado" ${ }^{108}$. Diante de problemas, costumar citar JK: "O otimista pode até errar, mas o pessimista já começa errando".

Duailibi relata que Alckmin, muito discreto, gosta de citar um conselho que diz ser de Juan Domingo Perón, ex-presidente da Argentina, à sua mulher Isabelita: "Fale muito das coisas, pouco das pessoas e nada sobre você". E completa: "Se não puder falar bem, não fale nada", outro ditado que ouvia do pai. Perguntado sobre o que achava de Lula, Alckmin disse que não gostava dele, nem do seu jeito de fazer política, mas, talvez por lembrar o conselho do pai, elogiou-o: “(...) eu o respeito, acho que ele é uma pessoa inteligente. O cara tem méritos, até a perseverança dele, foi cinco vezes candidato a presidente"109. Quando questionado sobre Dilma, disse que a presidente "sempre agiu de maneira correta" $" 110$ e demonstrou querer estabelecer com ela uma relação positiva.

Dentro do PSDB, Alckmin é visto como um político caipira que preserva valores provincianos, já que não tem vícios - não fuma e não bebe -, não fala francês e

\footnotetext{
107 “O paulista Ge-ral-do" por Julia Duailibi. Revista Piauí, n. 99, ano 8, 2014, dezembro, p. 23.

${ }^{108}$ Folha de S. Paulo, Primeiro Caderno, 29 de maio de 2005, p. 9.

109 "O paulista Ge-ral-do" por Julia Duailibi. Revista Piauí, n. 99, ano 8, 2014, dezembro, p. 24.

110 “O paulista Ge-ral-do” por Julia Duailibi. Revista Piauí, n. 99, ano 8, 2014, dezembro, p. 24.
} 
arrasta o inglês. Ele próprio se orgulha de dizer que não é elitista. Um integrante da sua campanha em 2014 atribuiu seu sucesso justamente a essa característica, que o faz parecer “(...) uma pessoa comum da classe média. Por isso, praticamente não precisa de pesquisas de grupo. O que ele pensa é o que pensa a média da população paulista"111.

Seu perfil pessoal apagado ou insignificante lhe rende alguns apelidos "chuchu diet", "político-água", "picolé de chuchu" - até mesmo por parte de companheiros de partido. Mas também faz com que, enquanto político, tenha baixo potencial de provocar um sentimento de rejeição no eleitorado, de modo que seu perfil “(...) não atrai antipatia, [tornando-se] um Teflon, nada gruda e não há como brigar com ele", explicou Roberto Romano, professor de filosofia política da Unicamp, na Folha de S. Paulo ${ }^{112}$.

Sabendo do que é chamado, Alckmin não se sente incomodado. Quando foi confirmado como candidato do PSDB à presidência da República em 2006, fazendo menção ao "picolé de chuchu", disse: "No meu governo, o Brasil vai crescer pra chuchu e terá trabalho pra chuchu"113. Segundo o marqueteiro Nelson Biondi, responsável pela campanha do tucano em 2014, a imagem de chuchu atribuída a Alckmin pela imprensa e por correligionários não casa com a imagem que a população paulista tem dele, a de um "cara com pulso", como disse a Duailibi ${ }^{114}$. Para Biondi, que já foi sócio de Duda Mendonça e ex-marqueteiro de Serra na campanha de 2002, e também de Maluf na eleição municipal em 2000, a boa avaliação de Alckmin pelos paulistas em áreas críticas como saúde e segurança se dá porque a população percebe nele a dedicação e o empenho para solucionar problemas.

Rogério Gentile, colunista da Folha de S. Paulo, descreveu-o como um político incomum, que "não fala alto, está sempre com a gravata alinhada e o colarinho branco, gosta de contar "causos" e é um ouvinte atento, capaz de passar horas escutando prefeitos e vereadores do interior com um sorriso discreto e ar acolhedor"115. Rende-lhe afeições o hábito de telefonar para prefeitos - e também para donos de postos de gasolina e outras pessoas que compõem sua rede interiorana de contatos. Nesse sentido, Alckmin sabe administrar como ninguém o que Bourdieu chamou de capital social.

\footnotetext{
111 “O paulista Ge-ral-do" por Julia Duailibi. Revista Piauí, n. 99, ano 8, 2014, dezembro, p. 20.

${ }^{112}$ Folha de S. Paulo, Eleições 2014, 05 de outubro de 2014, p. 12.

${ }^{113}$ Folha de S. Paulo, Primeiro Caderno, 15 de março de 2006, p. 8.

114 “O paulista Ge-ral-do" por Julia Duailibi. Revista Piauí, n. 99, ano 8, 2014, dezembro, p. 22.

${ }^{115}$ Folha de S. Paulo, Especial Mário Covas, 6 de março de 2001, terça-feira, p. 8.
} 
O psdebista Acir Filó, prefeito de Ferraz de Vasconcelos, é um dos que recebem ligações de Alckmin. Em entrevista a Julia Duailibi, Filó conta que "Em 2012, ele [Alckmin] ligou lá em casa num domingo de manhã. Fiquei tão encantado que poderia filmar o telefonema. Ele queria avisar que viria à cidade comer um pastel" ${ }^{116}$. Um ponto favorável a Alckmin são suas viagens pelo interior de São Paulo. Meticuloso, ele costuma, enquanto está no avião ou no helicóptero, aproveitar o tempo para repassar informações sobre o município que irá visitar, como o estágio de obras, por exemplo.

Nas eleições de 2002, Alckmin obteve o apoio de prefeitos de diversos partidos, o que compensou o seu árduo trabalho - que, ressalta-se, começou ainda quando era presidente do PSDB paulista - de reunir aliados por todos o estado, independentemente da filiação partidária. Nesse ano os prefeitos aliados atribuíram seu apoio à atenção que o governador dava às suas cidades.

Gilson Bargieri (PL), prefeito de Peruíbe, cidade do litoral paulista, mencionou na ocasião que "Alckmin faz tanta coisa para o meu município que eu não tenho outro caminho senão apoiá-lo"117. Para o prefeito de Poá, Eduardo Carlos Felippe, do PSD, "[chegava] o momento de agradecer a Geraldo, que ajudou todos nós com veículos, com remédios"118. Para outros, como José Carlos Teixeira (PPS), prefeito de Barra Bonita, a justificativa estava no fato de que seu partido já fazia parte da base de apoio do governador na Assembleia Legislativa e, por isso, o apoio era algo natural ${ }^{119}$.

Se Alckmin é atencioso com políticos de outros partidos, o é dez vezes mais com políticos tucanos. Em 2006, quando se lançou pré-candidato a presidente da República, disputando a vaga do partido com José Serra, saiu na frente do colega devido à sua perspicácia política. Duailibi conta que enquanto Serra, FHC e Aécio Neves se reuniram em um renomado restaurante italiano na Avenida Paulista para tratar da candidatura do partido, Alckmin, acompanhado do baixo clero do PSDB, foi a um rodízio de carnes de R\$15,90. Nesse ano, "Geraldinho", correndo pelas beiradas, foi escolhido como candidato à presidência mesmo sem o apoio das lideranças do partido.

Certamente ser um bom ouvinte ajuda Alckmin a captar aliados políticos, mesmo quando esses deveriam ser, em tese, opositores, como também ocorreu com os

\footnotetext{
116 “O paulista Ge-ral-do" por Julia Duailibi. Revista Piauí, n. 99, ano 8, 2014, dezembro, p. 27.

${ }^{117}$ Folha de S. Paulo, 16 de agosto de 2002.

118 Idem.

${ }^{119}$ Idem.
} 
prefeitos peemedebistas nas eleições de 2014, que o apoiaram apesar de terem um candidato próprio concorrendo ao governo. Quando Alckmin era candidato virtual do PSDB à presidência da República nas eleições de 2006, o deputado federal Xico Graziano (PSDB-SP), em fala dirigida ao governador, evidenciou por que Alckmin chegou ao sucesso eleitoral em SP: "Governador, continue com seu jeito, continue com sua simplicidade, vai andando, não só por SP, comece a andar pelo Brasil, que em 2006 está chegando aí e nós vamos voltar ao governo deste país"120.

Suas recorrentes viagens, a percorrer o estado, sua capacidade de telefonar, ouvir e de se aproximar de seus interlocutores, distraindo-os com causos, difere-o e o coloca na frente de José Serra, nome que ainda rivaliza com ele no PSDB paulista. Em 2002, Serra, candidato à presidência da República, teve complicações na campanha pelo interior de São Paulo devido a problemas de coordenação, agenda e estrutura ${ }^{121}$. Ele fazia poucas viagens ao interior e não tinha a mesma capacidade de articulação que Alckmin possui.

Para entender mais o comportamento de Alckmin e como ele o favorece, nada melhor do que observar mais detidamente José Serra, que é conhecido por ser o seu oposto no cenário político de São Paulo. Em 2005, quando Serra assumiu a prefeitura da capital, um colega de partido fez a seguinte observação: "Ele não liga no teu aniversário para te cumprimentar. Afabilidade e gentileza não são o seu forte. Se está conversando em um restaurante com alguém e chega uma terceira pessoa querendo sentar-se à mesa, Serra tem a frieza necessária para pedir ao intruso que se retire"122. Outro correligionário, Renilson Rehem, ex-secretário nacional de Assistência à Saúde na época em que Serra era ministro da Saúde do governo FHC, disse que o tucano “(...) detesta conversa arrastada e decide muito rapidamente" 123 , comportamentos que se opõem claramente aos de Alckmin, que pode passar horas falando ou simplesmente escutando. Covas, assim como Serra, também tinha fama de ser turrão, mas equilibrava essa característica com seu jogo de cintura, qualidade que parece faltar a seu companheiro.

A imagem de arrogante acompanha Serra desde a época em que ele era secretário de Economia e Planejamento do governador Franco Montoro em São Paulo

\footnotetext{
${ }^{120}$ Folha de S. Paulo, Primeiro Caderno, 20 de maio de 2005, p. 4.

${ }^{121}$ Idem.

${ }^{122}$ Folha de S. Paulo, Folha Cotidiano, 2 de janeiro de 2005, p. 4.

123 Idem.
} 
(1983-1987). De acordo com o ex-deputado estadual Paulo Ricardo Montoro (PSDB), filho e à época secretário particular do ex-governador, "Tinha um monte de gente no governo que preferia ver o diabo a ter que falar com o Serra. Ele ganhou muitos desafetos apesar de seu grande poder de decisão e de se cercar de uma equipe excelente" ${ }^{\text {"124 }}$.

Ao passo que Alckmin é um bom interlocutor que normalmente escuta aliados e sua equipe antes de tomar uma decisão, Serra é curto e grosso mesmo com os auxiliares mais próximos. Ambos valorizam o gerenciamento e o trabalho, no entanto, ao contrário de Serra, Alckmin consegue conduzir o governo e prezar as relações pessoais ao mesmo tempo, sendo aprazível e gentil. Considerando que no meio político a capacidade de governar, e antes, de chegar ao poder, passa pela habilidade de fazer relações públicas, Ricardo Montoro foi sábio ao dizer que "se Serra tivesse tido no passado um comportamento afável (...) ele já poderia ter colhido êxitos maiores. Populismo não é com o José Serra",125.

Prezando características contrárias à aspereza atribuída a Serra, Alckmin passa ao eleitorado a imagem de bom moço, possuidor de valores familiares, e deve a ela grande parte de sua projeção na política paulista. A abertura de seu último programa na TV, em 27 de outubro de 2006, como candidato à presidência da República em 2006, é um exemplo de como ele se vale do título 'político família' para angariar a empatia dos eleitores ${ }^{126}$. Nele, Alckmin aparece sentado em um ambiente familiar ao lado da esposa, Maria Lúcia Alckmin, e dos três filhos. A mulher é a primeira a falar: "É um pai maravilhoso, um marido exemplar, é um amigo. Eu acho que é um avô também muito querido". Em seguida, o filho: "Nossa família é muito unida. Dá pra perceber isso, que a gente vai junto aos debates, a gente vai junto a todo lugar". Os filhos o enchem de elogios, imputando-lhe força, determinação, coragem e amadurecimento precoce. É evidente a relação que se tenta fazer entre valores e princípios familiares e vida pública, Alckmin, que aparece como um "homem de bem", encerra os depoimentos: "seja na vida pública, seja na vida particular, precisa ter princípios, precisa ter valores que norteiam essa caminhada".

Ao articular o perfil de bom homem e a capacidade de angariar o apoio de prefeitos, Alckmin ganha eleitores: "Voto em Alckmin porque é um homem bom e porque

\footnotetext{
124 Idem.

${ }^{125}$ Idem.

${ }^{126}$ Ver https://www.youtube.com/watch?v=10wZQm5emno.
} 
a ex-prefeita pediu" "27, disse à Folha de S. Paulo Saturnino Fogaça, eleitor aposentado, morador da cidade interiorana de Taquarivaí.

Sendo um administrador cuidadoso que levanta cedo para trabalhar, Alckmin também costuma ouvir aqueles que fazem parte de sua equipe e reflete bastante antes de decidir sobre qualquer coisa. Gentile conta que Alckmin, "na campanha para prefeito, fazia longas reuniões noturnas com arquitetos e técnicos em transporte para se aprofundar sobre os problemas urbanísticos de São Paulo"128.

Antes da campanha de 2010, mergulhando na máquina estadual, reuniu-se periodicamente em reuniões longas com secretários de várias pastas - Educação, Saúde, Segurança Pública e Gestão -, a fim de captar informações sobre os setores cruciais do governo $^{129}$. Para exemplificar seu jeito metódico e organizado, anota tudo o que ouve em audiências num caderno, para não esquecer nenhuma recomendação, proposta ou demanda: “(...) no gabinete, mantém quatro cadernos universitários, onde anota dados das reuniões com secretários e aos quais recorre para checar informações", relata Duailibi ${ }^{130}$. A jornalista também observa, após conviver com Alckmin durante e após a campanha, que ele é "obsessivamente didático", expressando-se de forma profundamente articulada e fazendo, durante a fala, perguntas às quais ele mesmo responde.

Alckmin, ao considerar que as maiores lacunas da política são o bom gerenciamento, a seriedade e a austeridade, não se acha conservador, mas sim um socialdemocrata pragmático. A propaganda partidária contribui com sua imagem de bom gerente da coisa pública. A inserção do PSDB na TV em São Paulo em 2005 o apresentava como um político com "olhos para o futuro", preocupado com o desenvolvimento e a geração de empregos. O slogan de sua pré-candidatura para 2006 era "Por um Brasil competente, Geraldo Alckmin presidente".

Em suas campanhas, deixa explícito que experiência na vida pública é sinônimo de competência. No evento de lançamento de sua pré-candidatura ao governo de São Paulo em 2010, disse que "o governo não é um curso de graduação, de madureza, nem de pós-graduação [no qual] quem ganha vai aprendendo no governo o que fazer, enquanto a necessidade da população fica sem atenção"131.

${ }^{127}$ Folha de S. Paulo, Eleições 2014, 5 de outubro de 2014, p. 12.

${ }^{128}$ Folha de S. Paulo, Especial Mário Covas, 6 de março de 2001, terça-feira, p. 8.

${ }^{129}$ Folha de S. Paulo, Primeiro Caderno, 4 de junho de 2010, p. 6.

130 "O paulista Ge-ral-do" por Julia Duailibi. Revista Piauí, n. 99, ano 8, 2014, dezembro, p. 27.

${ }^{131}$ Folha de S. Paulo, Primeiro Caderno, 09 de maio de 2010, p. 4. 
Autointitulando-se, em tom de brincadeira, "o único tucano franciscano"132, contrapondo, com isso, seu estilo de vida ao das demais lideranças de seu partido, tem orgulho de dizer que "Antes de ser político, eu me prezo de ser cristão"133, característica que deve agradar principalmente aos eleitores mais velhos do interior. Um dos responsáveis pelas pesquisas encomendadas pelo governo paulista caracterizou Alckmin como "um cara conservador, extremamente católico. Tem uma atitude republicana e uma visão cristã das coisas. Entre que o Estado tem que ajudar os mais pobres, mas não é nem de longe um revolucionário. É um Montoro sem a mesma solidez democrática”"134.

A religiosidade da família Alckmin foi uma herança deixada pela avó paterna, Ida Ravache, que era descendente de alemães. Católico praticante de Pindamonhangaba, hábito passado pelo pai, ex-integrante da Terceira Ordem de São Francisco, Alckmin sabe de cor todos os mistérios do terço e vai à missa quase todo domingo. Seu tio, José Geraldo, ex-ministro do STF, foi um influente membro da Opus Dei, movimento conservador da Igreja Católica, criado em meados do século XX.

Alckmin, influenciado por seu tio, quando morou com ele na capital, enquanto fazia cursinho, se afeiçoou à Obra, forma como é chamada a Opus por seus integrantes, e, desde 1976, "carrega na carteira um bilhete do pai com uma passagem de O Caminho, livro com ensinamentos do fundador da Obra [o padre espanhol José María Escrivá]"135, relata Duailibi. Algumas reuniões religiosas realizadas, em 2005, na parte residencial do Palácio dos Bandeirantes com pessoas ligadas à Opus, renderam ao governador alguns questionamentos e, por isso, ele se afastou do movimento. Hoje, limita-se a dizer que tem grande "apreço" e "respeito" por quem faz parte dele.

Se a religião é um facilitador da relação entre Alckmin e uma parte de seus eleitores, os cafezinhos cumprem a mesma função e é entre um e outro que Alckmin consegue circular entre vários segmentos, desde empresários a garçons. Em suas andanças por São Paulo, prefere parar e tomar um cafezinho em estabelecimentos simples a fazê-lo em restaurantes ou bares caros.

O governador, que não anda em carro blindado e diminuiu sua segurança pessoal, alegando, segundo Duailibi, que o contrário disso poderia não ser visto com bons

\footnotetext{
132 “O paulista Ge-ral-do" por Julia Duailibi. Revista Piauí, n. 99, ano 8, 2014, dezembro, p. 21.

${ }^{133}$ Folha de S. Paulo, Folha Eleições, 26 de outubro de 2002.

134 “'O paulista Ge-ral-do" por Julia Duailibi. Revista Piauí, n. 99, ano 8, 2014, dezembro, p. 20.

135 “O paulista Ge-ral-do" por Julia Duailibi. Revista Piauí, n. 99, ano 8, 2014, dezembro, p. 26.
} 
olhos pela população, costuma visitar uma vez por semana Paraisópolis, favela que fica a menos de dois quilômetros da sede do governo no Morumbi. Entre cafezinhos, Alckmin conversa com os moradores, ao lado de seu motorista e do ajudante de ordens, conta Duailibi, que acompanhou o governador em sua ida à favela dois dias depois de sua vitória em outubro de 2014.

Ao fazer isso, ele põe em prática a sua tese de que "em política, você não obriga, você conquista". Também foi pensando assim que conversou com os moradores de assentamentos em São Paulo, regiões onde perdeu nas eleições de 2010. Após levar energia elétrica para essas localidades e estabelecer uma parceria entre o governo e agricultores familiares, Alckmin, nas últimas eleições, somou votos entre os assentados. Questionando a teoria do voto determinado, Alckmin disse a Duailibi que “(...) não tem essa história de que o eleitor tem carteirinha"136.

Alckmin preza muito por sua imagem perante o eleitorado, pois sabe das vantagens que podem advir desse zelo. O sociólogo Antônio Lavareda, encarregado pelas pesquisas qualitativas do governo tucano em períodos eleitorais, disse a Alckmin, quando ele foi reeleito governador em 2014, que sua vitória tinha ocorrido "mais pela aprovação à sua imagem do que pela sua gestão"137.

No entanto, mesmo obtendo bons índices de aprovação, nem sempre as pessoas o reconhecem quando anda nas ruas de São Paulo. Se seus correligionários criticam seu governo por não ter uma grande marca, a sua figura física também parece não ser tão marcante entre os eleitores. Segundo Duailibi, "Alckmin conta que é confundido com Britto Júnior, apresentador da Record, e que já o chamaram de Serra e até de Maluf"138.

O governador parece não se incomodar com essa dose de desconhecimento, embora já seja a quarta vez que ocupa o posto máximo no estado, e indica a "identidade" com o povo paulista como uma das causas de suas vitórias. Fernando Henrique Cardoso concorda com Alckmin e vê nele "o espírito de São Paulo", relata Duailibi. Pode-se perguntar: mas a que se refere essa identidade, esse espírito paulista? O nome do palácio que é sede do governo de SP dá uma pista: Palácio dos Bandeirantes.

É interessante lembrar que o destaque político-administrativo e econômico do estado de São Paulo remonta aos tempos coloniais, ainda quando se chamava Capitania de

\footnotetext{
136 “'O paulista Ge-ral-do” por Julia Duailibi. Revista Piauí, n. 99, ano 8, 2014, dezembro, p. 23.

${ }^{137}$ Idem, p. 20.

${ }^{138}$ Idem, p. 22.
} 
São Vicente. Desde a época em que o Brasil era apenas mais uma das colônias de Portugal, São Paulo destacava-se pelas características do seu povo, tido como desbravador e corajoso, por suas potencialidades na agricultura, dada a vasta terra a explorar, bem como por sua posição geográfica, que fazia da capitania um escudo protetor da capital e das fronteiras ameaçadas pelos espanhóis.

A caça de índios e a busca do ouro levaram à atividade exploradora de territórios. Para citar Gilberto Freyre, São Paulo foi "autocolonizada" pela gente paulista, que “(...) participou mais do que nenhuma através de Bandeirantes que, ao sangue ibérico português e espanhol - juntavam quase sempre o indígena" (BRUNO, 1953, p. XIV). O desbravamento das terras brasileiras desconhecidas ocorreu com a ajuda das bandeiras, expedições que, embora tenham partido de todos os cantos da colônia, ganharam popularidade graças aos bandeirantes que advinham da região que hoje se denomina São Paulo. Bandeirante, no senso comum, tornou-se sinônimo de paulista. "Nós, paulistas, nos orgulhamos de ser um povo bandeirante, um povo que como antigos desbravadores, vai sempre em frente, é sempre vai à frente", disse Alckmin quando tomou posse em 2003.

A Coroa Portuguesa, embora qualificasse os paulistas de “(...) gente tão arredia à submissão" (BELLOTTO, 2007, p. 89), considerava-os os soldados mais próprios para expulsar da terra os espanhóis e os jesuítas. Para tanto, sempre que podia e quando era de sua conveniência, fomentava a vaidade dos paulistas, exaltando sua impavidez e seu desprendimento, “(...) lembrando-lhes os feitos dos antepassados contra os castelhanos" (BELLOTTO, 2007, p. 61).

Exemplo disso é o discurso de posse de Morgado de Mateus, primeiro governador de São Paulo após a restauração ${ }^{139}$, que engrandecia as realizações dos paulistas e apontava o quanto São Paulo merecia ter seu "antigo esplendor" renovado:

Foi Sua Magestade servido de me mandar com o governo desta Capitania, encarregando-me de procurar por todos os meyos estabelecela ao seu antigo esplendor, procurando os modos mais efficazes de acrescentar as suas povoaçõens, estender aos confins dos seus dominios, fertilizar os campos com a agricultura, estabelecer nas terras diferentes fabricas, idear novos caminhos,

\footnotetext{
${ }^{139}$ Por ordem da Coroa, São Paulo perdeu seu Governador e Capitão General em 1748 e, deixando de ter status de capitania, passou a ser subordinada ao Rio de Janeiro. A decisão, além de servir os fins de proteção e de vigilância das regiões auríferas, atendeu aos interesses das autoridades que acreditavam que o Sul do país deveria ficar sob um só comando, visando à defesa do território. A capitania paulista foi restaurada somente em 1764, tendo em vista que a distância e a dificuldade de comunicação entre a capital da colônia e as localidades mais importantes e ameaçadas do Sul impediam que a região sulina estivesse sob o controle central do Rio de Janeiro apenas.
} 
penetrar incognitos sertõens, descobrir o ouro das suas minas e finalmente, fortificar as suas Praças, armar o seu Exército, fazer observar as Leys e respeitar as Justiças $^{140}$.

São Paulo, considerado atualmente o estado mais importante da federação, possui particularidades históricas que saltam aos olhos e que são utilizadas na estratégia dos tucanos paulistas para a abordagem do eleitorado. Acredita-se que Geraldo Alckmin enaltece o passado, assim como fez Covas, almejando mobilizar a identidade do paulista, ligada ao passado aventureiro e desbravador do bandeirante, em favor de um corpo político específico.

Em 2011, quando assumiu o governo paulista, Alckmin asseverou que olhar para o futuro de São Paulo requeria contemplar o passado do estado, a história de trabalho e luta da qual os paulistas de hoje, segundo ele, fazem parte. Falou do espírito que movia os primeiros habitantes de São Vicente, citando, para isso, um trecho de carta escrita na capitania em 1568 pelo jesuíta Baltazar Fernandes: "Andamos, ordinariamente, descalços, passando águas, que há muitas nesta terra, e isso não uma vez, senão frequente; passamos caminhos e matos mui trabalhosos, e muitas vezes não temos nem um punhado de farinha da terra para comer" ${ }^{\prime 14}$.

Ao lembrar os esforços dos jesuítas, citou-os como o seu exemplo de trabalho e de predisposição ao serviço da população:

(...) orgulha-me pensar que a pujança de São Paulo deve-se ao fato de que as muitas águas, que sempre existiram nesta terra, tornaram-se ainda mais abundantes quando a elas se juntou o suor de gerações de trabalhadores. Hoje, me apresento diante do povo como mais um desses incansáveis trabalhadores. (...) Assumo o compromisso de trabalhar todos os dias, desde o primeiro dia. (...) De dar, permanentemente, o exemplo, personificar os valores e princípios que formam e nos quais acreditam os paulistas" ${ }^{\prime 14}$.

A relação que se faz entre o paulista e o trabalho é nítida e recorrente, e muitas vezes essas palavras parecem ser sinônimas, quando colocadas no mesmo discurso, como pode ser visto nas palavras de Alckmin: "Porque mais que de usinas, rodovias, fábricas, a força de São Paulo vem do seu povo, gente que confia no poder transformador do trabalho.

\footnotetext{
${ }^{140}$ Discurso de posse de Morgado de Mateus no governo de São Paulo, 1766. Apud BELLOTTO, 2007, p. 77.

${ }^{141}$ Ver discurso completo em http://www1.folha.uol.com.br/poder/853674-leia-integra-do-discurso-de-possede-geraldo-alckmin-no-palacio-dos-bandeirantes.shtml.

${ }^{142}$ Idem.
} 
A força de São Paulo vem da sua gente, que trouxe dos quatro cantos do País, dos quatro cantos do mundo a certeza de vencer, oferecendo a seus filhos um futuro melhor. Por isso, São Paulo é a terra do trabalho"

O tucano de Pindamonhangaba disse ainda em 2011: "Confio poder trabalhar com a mesma determinação dos paulistas, que todos os dias tocam em frente suas vidas, com muito esforço e dedicação" ${ }^{144}$. Em 2014, quando viveu em SP a crise da água, que poderia ter desastrosas consequências eleitorais, Alckmin novamente qualificou, inclusive em seus programas eleitorais, o paulista como autônomo e diligente, colocando-o em primeiro plano: "O desenvolvimento de São Paulo é, antes de tudo, fruto das melhorias alcançadas pela própria população. A cada decisão individual (...) quem ganha é São Paulo. O Estado avança, desenvolve-se, emancipa-se. O governo entra como parceiro, através da geração de oportunidades e do apoio a quem mais precisa" ${ }^{145}$.

Ao exaltar a figura do paulista forte e trabalhador, Alckmin leva adiante o slogan utilizado por Covas, que, como governador, foi taxativo quanto à dedicação do paulista ao labor, como evidencia o seu discurso de posse do segundo mandato:

Seja por uma questão de seriedade, seja por patriotismo, seja até por conveniência, São Paulo jamais virará suas costas ao Brasil. (...). Este país tem urgências. O Brasil não suporta mais adiar a retomada do desenvolvimento. São Paulo convoca a todos para esta árdua tarefa de construção e oferece, desde logo, todo seu vigor e amor à Pátria, sem temor e sem vacilação. Ao trabalho, paulistas! $!^{146}$

Como dito, Alckmin segue o exemplo de Covas, que, no discurso de posse do primeiro mandato em 1995, cita, como se pode ver no trecho abaixo, "a responsabilidade histórica” de São Paulo, responsabilidade, segundo Gilberto Freyre, “(...) cujo sentido só se esclarece pelo exato conhecimento do passado regional paulista em comparação com os de outras regiões do continente" (BRUNO, 1953, p. XVIII).

Tomo posse com humildade diante da grandeza de São Paulo - uma Argentina encravada no coração do Brasil. Sou portador de boa nova. Carrego a esperança que chegou a hora de resgatar duas dignidades. A de São Paulo, para que se reafirme como Estado-líder da federação; a da população desvalida, para que

\footnotetext{
${ }^{143}$ Em www.casacivil.sp.gov.br/biblioteca-ccivil/DiscursosFile.asp?id=12.

144 Em http://www1.folha.uol.com.br/poder/853674-leia-integra-do-discurso-de-posse-de-geraldo-alckminno-palacio-dos-bandeirantes.shtml.

${ }^{145}$ Folha de S. Paulo, Eleições 2014, 04 de outubro de 2014, p. 3.

$146 \mathrm{Ver}$ discurso completo em http://www.fundacaomariocovas.org.br/mariocovas/pronunciamentos/posseseggovsp/.
} 
conquiste efetiva cidadania. (...) São Paulo sempre padeceu de uma carência: desde os anos 30, nunca pôde equiparar sua influência política a seu peso econômico. Chegou a vez, por isso mesmo, de devolver a São Paulo a voz que lhe pertence. Uma voz que corresponde à sua importância estratégica. Mais ainda: é urgente recuperar o dinamismo econômico que sempre fez São Paulo uma alavanca do desenvolvimento brasileiro ${ }^{147}$.

As falas dos políticos psdebistas que governaram e ainda governam São Paulo aproximam-se daquelas proferidas pelos governantes de tempos remotos, ainda coloniais, o que destaca a inclinação dos representantes paulistas para incentivar e engrandecer a autoimagem de seus conterrâneos. Considera-se que o PSDB em São Paulo, por meio de seus candidatos, tornou-se no estado o herdeiro legítimo do discurso de autoengrandecimento promovido pelos antepassados, discurso esse que pode ser exemplificado pela caracterização que a britânica Maria Graham faz do paulista na sua passagem pelo Brasil no século XIX: "Os paulistas são considerados os mais audazes, generosos e esclarecidos entre os brasileiros" (GRAHAM, 1956, p. 80).

São Paulo, por razões antigas e atuais, sempre se distinguiu do restante do Brasil, representando para muitos uma "terra da esperança", como disse Alckmin em discurso proferido em 2003. Outro trecho informa mais claramente acerca do pensamento que instiga e ao mesmo tempo reproduz em palavras a significância do estado:

\begin{abstract}
São Paulo não é somente parte do grande corpo que forma o Brasil; é o seu órgão mais vital. O progresso paulista circula, nutre, irriga o país como sangue das veias mesclando o destino do povo da nossa terra ao de todos os brasileiros. São Paulo pode não ser a alma do Brasil, mas é a sua melhor síntese. São paulistas os que nasceram às bordas do Tietê e os que para cá vieram do sertão e das margens do São Francisco. São paulistas os que trouxeram do Rio o riso largo dos cariocas e os criados à sombra amiga dos pinheirais e das seringueiras. São paulistas os que vêm da fronteira, o corpo enregelado pelo Minuano, o coração ardente como o de todos os brasileiros. Ser paulista não é ter nascido aqui ou ali. É uma maneira de enxergar o Brasil e de trabalhar por ele ${ }^{148}$.
\end{abstract}

Gilberto Freyre, reconhecendo o poder de atração que SP ainda hoje exerce sobre os indivíduos, o que o faz ser destino de migrantes e imigrantes, utilizou como exemplo de sua reflexão a observação feita pelo professor europeu Tullio Ascarelli, que chegava “(...) a considerar São Paulo o centro de "americanização" (...) da vida brasileira, no sentido de ser a área do País onde maior se apresenta "a natural predominância

\footnotetext{
${ }^{147}$ Ver discurso completo em http://www.fundacaomariocovas.org.br/mariocovas/pronunciamentos/possegovsp/.

${ }^{148} \mathrm{Em}$ www.casacivil.sp.gov.br/biblioteca-ccivil/DiscursosFile.asp?id=12.
} 
psicológica da esperança no futuro sobre a tradição de um breve passado..."” (BRUNO, 1953 , p. X).

Freyre, no entanto, alerta para o perigo de que haja em São Paulo o pior sentido da "americanização", aquela que estima "o adventício branco que, filho de operário ou de camponês europeu, se engrandeça pelo esforço próprio (self-made man, strenuous man etc.) em barão industrial mas [cria] obstáculos à ascensão social do brasileiro ou do paulista (...) que conserve no rosto e no corpo marcas demasiadamente visíveis da origem africana" (BRUNO, 1953, p. XII).

Não obstante esse apontamento, o certo é que a valorização do ter pelas próprias mãos e pelo próprio esforço, o que pode ser resumido na imagem do self made man citada por Freyre, existe e parece casar com o discurso construído pelos vitoriosos psdebistas em São Paulo.

Alckmin, ao elogiar o publicitário Caio de Alcântara Machado, construtor do parque Anhembi, chamou-o de "bandeirante do século XX"149, tendo em vista sua contribuição para o crescimento do turismo e, por consequência, da economia paulista. No seu discurso de posse em $1^{\circ}$ de janeiro de 2015, afirmou que "ser paulista é enfrentar os desafios com trabalho". Para complementar sua definição, citou o poeta nascido em Santos, Martins Fontes:

Ser paulista é ser grande no passado E inda maior nas glórias do presente! E' ser a imagem do Brasil sonhado, E, ao mesmo tempo, do Brasil nascente ${ }^{150}$.

\footnotetext{
${ }^{149}$ Ver Folha de S. Paulo, Primeiro Caderno, 06 de junho de 2002, p. 9.

${ }^{150}$ Discurso completo em http://www.saopaulo.sp.gov.br/spnoticias/lenoticia2.php?id=239110.
} 


\section{CAPÍTULO 4 - ANTIPETISMO EM SP? DIFICULDADES DO PARTIDO DOS TRABALHADORES COMO COMPETIDOR PELO GOVERNO PAULISTA}

\subsection{Breve história do partido e trajetória da luta pelo governo paulista}

Criado oito anos antes do PSDB, o Partido dos Trabalhadores (PT) foi fundando em 10 de fevereiro de 1980, no Colégio Sion, em São Paulo. Na época, havia a dúvida de que se a criação, ainda na ditadura, de um novo partido popular seria benéfica para a transição democrática ou serviria para enfraquecer o Movimento Democrático Brasileiro (MDB), que até o momento era a contraposição do partido da Aliança Renovadora Nacional (ARENA).

Entre as várias alternativas, a ideia do PT se firmou e os movimentos operários ocorridos no final dos anos 1970, juntamente com suas lideranças, tiveram um peso decisivo na sua criação, que também foi viabilizada pelas circunstâncias da época. Em 1980 a ditadura já não tinha a mesma força dos anos 60, e seu aparelho repressivo intimidava cada vez menos, o que sinalizava tendências à democratização, mesmo entre pessoas da elite.

O declínio dos regimes ditatoriais nos países das Américas também favoreceu as democracias que estavam por vir, assim como contribuiu o pensamento do então presidente dos Estados Unidos, Jimmy Carter, que simpatizava com a queda das ditaduras, contanto que elas fossem substituídas em ordem (REIS, 2007). Estruturado nesse contexto, o PT reuniu lideranças sindicais, revolucionários marxista-leninistas e militantes da esquerda católica.

$\mathrm{Na}$ data de sua fundação, o PT lançou um manifesto assinado por 101 pessoas, onde se esclarecia que o partido nascia “(...) da necessidade sentida por milhões de brasileiros de intervir na vida social e política do País para transformá-la [bem como] da decisão dos explorados de lutar contra um sistema econômico e político que não pode resolver os seus problemas, pois só existe para beneficiar uma minoria de privilegiados"151.

Ainda segundo o texto, o partido teria como meta "chegar ao governo e à direção do Estado para realizar uma política democrática, tanto do ponto de vista

\footnotetext{
${ }^{151}$ Em Folha de S. Paulo, Primeiro Caderno, 11 de janeiro de 1980, p. 5.
} 
econômico quanto social, [para que] não haja explorados nem exploradores"152. Seu primeiro grande comício ocorreu em Osasco, onde foi apresentado o seu projeto de programa, reafirmando que o berço petista seria o estado de São Paulo, onde mais tarde também nasceria o seu principal rival, o PSDB.

As eleições gerais de 1982, que ocorreram para a escolha dos governadores dos estados, já apresentaram a interferência da criação do PT na estratégia dos demais partidos, principalmente do PMDB (ex-MDB) paulista. Em junho, a convenção estadual do PMDB iria decidir entre a candidatura de Orestes Quércia ou Franco Montoro para o governo do estado; todavia a escolha do vice era ainda uma incógnita.

Entre muitas alternativas, falava-se em escolher um nome ligado à Igreja, com a justificativa de que isso minimizaria a simpatia dos católicos pelo PT, que contava desde a sua fundação com o apoio de setores da Igreja Católica. Talvez isso haja influenciado na vitória apenas parcial da chapa de Montoro, já que o seu candidato a vice, Mário Covas, foi desbancado por Quércia, político católico que tinha todos os filhos batizados na Igreja de Roma, e que, beneficiando-se também da pressão feita por aliados, foi exigido por parte significativa dos convencionais como o candidato a vice.

Enquanto isso, o PT já tinha um candidato praticamente certo para o governo paulista: Luís Inácio Lula da Silva, presidente do Sindicato dos Metalúrgicos de São Bernardo. Lula concorreu, além de Montoro, com Jânio Quadros (PTB), Reinaldo de Barros (PDS) e Rogê Ferreira (PDT). O PMDB, por ter sido durante boa parte da ditadura o único partido de oposição ao regime, ganhou destaque na eleição paulista e seu candidato chegou a propor, dois meses antes do pleito, uma coalizão oposicionista, apontando que "todos os partidos que são contra o governo autoritário e entreguista que aí está têm de se unir para provocar as transformações necessárias na sociedade"153.

Lula considerou a proposta uma "petulância" do candidato peemedebista e, pouco depois do episódio, o PT decidiu apontar o PMDB como aliado das forças reacionárias, afirmando que este já começava “(...) a acordar para a infiltração arenista no partido"154. Valendo-se de um discurso duro, especialmente contra o PMDB, o petista

\footnotetext{
152 Idem.

${ }^{153}$ Folha de S. Paulo, Primeiro Caderno, 15 de setembro de 1982, p. 1.

${ }^{154}$ Folha de S. Paulo, Primeiro Caderno, 24 de setembro de 1982, p. 1.
} 
chegou a afirmar que existia no país “(...) um pacto nacional entre setores da direita e dos liberais para evitar que o PT derrube a corrupção que se instalou no país em 1964"155.

Mesmo com o ataque ao PMDB, principal adversário, e com os esforços, em que pese a falta de recursos da campanha, para fortalecer o partido nas cidades médias e pequenas, Lula e o PT não conseguiram o sucesso que esperavam e, devido à desconfiança do eleitorado paulista em relação ao seu discurso áspero, terminaram apenas em quarto lugar na disputa, com pouco mais de 1 milhão de votos (9,87\% dos votos válidos), atrás de Reinaldo de Barros e Jânio Quadros, para surpresa do vitorioso candidato peemedebista. Lula, um dia antes da eleição, chegou a admitir que não conseguira sensibilizar boa parte do eleitorado paulista: "Acho que não conseguimos atingir o grande público com a nossa mensagem porque os grandes veículos de comunicação não veicularam essa ideia"156.

Já Aírton Soares, líder do PT na Câmara Federal, observou que os resultados desanimadores de seu partido nas eleições gerais tinham como causa o radicalismo e o discurso excessivamente agressivo dos candidatos ${ }^{157}$. No entanto, minimizou a quarta colocação e apontou perspectivas futuras para o partido no estado, tendo em vista que "pela primeira vez, quase 1 milhão e meio de pessoas votaram num operário para governador" ${ }^{, 158}$.

Em 19 de novembro, quando a apuração ainda não havia terminado, o resultado já estabelecia Franco Montoro como vencedor, com mais de 3 milhões de votos a mais que Lula, conforme evidenciado na tabela 6.

Nessa eleição, o PT também ficou com a quarta colocação na Assembleia Legislativa paulista: elegeu move deputados, ao passo que o primeiro colocado PMDB ocuparia 42 das 84 cadeiras. Com a vitória não só em São Paulo, mas em outros estados da federação (Minas Gerais, Espírito Santo, Paraná, Goiás, entre outros), o PMDB parecia destinado a ser o principal partido da oposição no Brasil. Em São Paulo, encaminhava-se para ter destaque eleitoral entre os municípios interioranos (tabela 8).

\footnotetext{
${ }^{155}$ Folha de S. Paulo, Primeiro Caderno, 8 de novembro de 1982, p. 5.

${ }^{156}$ Folha de S. Paulo, Primeiro Caderno, 15 de novembro de 1982, p. 6.

${ }^{157}$ Folha de S. Paulo, Primeiro Caderno, 23 de novembro de 1982, p. 5.

158 Idem.
} 
Tabela 8 - Resultado parcial (em 19/11/1982) da eleição em 1982 para governador em São

Paulo

\begin{tabular}{|c|c|c|c|c|c|c|}
\hline \multirow[t]{2}{*}{ Candidatos } & \multicolumn{2}{|c|}{ Votação geral } & \multicolumn{2}{|c|}{$\begin{array}{c}\text { Votação capital } \\
\text { (total de } 7.400 \\
\text { urnas) }\end{array}$} & \multicolumn{2}{|c|}{$\begin{array}{l}\text { Votação Grande } \\
\text { SP/interior ( } 341 \\
\text { cidades) }\end{array}$} \\
\hline & $\begin{array}{c}\text { Votos } \\
\text { nominais }\end{array}$ & $\%$ & $\begin{array}{c}\text { Votos } \\
\text { nominais }\end{array}$ & $\%$ & $\begin{array}{c}\text { Votos } \\
\text { nominais }\end{array}$ & $\%$ \\
\hline Franco Montoro (PMDB) & 4.077 .960 & 48,1 & 1.226 .926 & 43,1 & 2.851 .034 & 50,7 \\
\hline Reinaldo de Barros (PDS) & 2.035 .797 & 24 & 543.380 & 19,1 & 1.492 .417 & 26,5 \\
\hline Jânio Quadros (PTB) & 1.027 .878 & 12,1 & 560.003 & 19,7 & 467.875 & 8,3 \\
\hline Lula (PT) & 840.653 & 9,9 & 416.729 & 14,6 & 423.924 & 7,5 \\
\hline Rogê Ferreira (PDT) & 63.267 & 0,7 & 36.037 & 1,2 & 27.230 & 0,5 \\
\hline Brancos & 422.919 & 4,9 & 63.081 & 2,2 & 359.838 & 6,4 \\
\hline Nulos & 223.138 & 2,6 & 73.265 & 2,5 & 159.863 & 2,7 \\
\hline Total de votos & \multicolumn{2}{|c|}{8.701 .602} & \multicolumn{2}{|c|}{2.919 .421} & \multicolumn{2}{|c|}{5.782 .181} \\
\hline
\end{tabular}

Nas eleições seguintes, em 1986, o PT lançou a candidatura do então deputado federal Eduardo Suplicy para o governo paulista. Quércia, vice-governador de São Paulo, que em janeiro foi apontado pelos membros do Diretório e da Executiva Regional do PMDB como o candidato preferido, foi o escolhido e contava com o apoio de PSB, PCdoB e PCB. A disputa foi completada ainda pelo empresário Antônio Ermírio de Moraes (PTB), Paulo Maluf (PDS) e Teotônio Simões (PH).

Em março, pesquisa do Datafolha apontou Suplicy como o candidato preferido na capital $(28 \%)$, na frente de Quércia $(23 \%)$ e Maluf $(16 \%)^{159}$. Na época, a população paulistana representava cerca de $32 \%$ do eleitorado no estado. Perto da eleição, outra pesquisa do Datafolha ${ }^{160}$ mostrava Quércia na frente nas intenções de voto, enquanto Suplicy estava na quarta colocação, posição que se repetia para o petista para a preferência na capital, na Grande São Paulo e no interior do estado.

Essa previsão foi confirmada em novembro, conforme mostra a tabela 9: mais uma vez, a vitória dos peemedebistas, com destaque eleitoral para as cidades do interior, e mais um quarto lugar com cerca de 1 milhão e meio de votos para o PT, que teve uma boa performance entre os municípios da região metropolitana, principalmente no $\mathrm{ABC}$ paulista (São Bernardo do Campo, Santo André, São Caetano do Sul e Diadema).

\footnotetext{
${ }^{159}$ Folha de S. Paulo, Primeiro Caderno, 23 de março de 1986, p. 4.

${ }^{160}$ Pesquisa divulgada em Folha de S. Paulo, Primeiro Caderno, 23 de outubro de 1986, p. 8.
} 
José Dirceu, na época secretário-geral do PT paulista, chegou a dizer sobre a vitória peemedebista que "Para milhões de pessoas, o PMDB ainda é o partido das mudanças"

\begin{tabular}{l|cc}
\multicolumn{3}{c}{\begin{tabular}{c} 
Tabela 9 \\
\multicolumn{2}{c}{ - Resultado da eleição em 1986 para } \\
governador em São Paulo
\end{tabular}} \\
\hline \multirow{2}{*}{ Candidatos } & \multicolumn{2}{|c}{ Votação geral } \\
\cline { 2 - 3 } & \multicolumn{2}{|c}{ Votos } \\
nominais & $\%$ \\
\hline Orestes Quércia (PMDB) & 5.578 .795 & 40,78 \\
Ermírio de Moraes (PTB) & 3.675 .176 & 26,86 \\
Paulo Maluf (PDS) & 2.668 .425 & 19,5 \\
Eduardo Suplicy (PT) & 1.508 .589 & 11,0 \\
Teotônio Simões (PH) & 250.657 & 1,8 \\
\hline
\end{tabular}

Fonte: Elaboração da autora a partir dos dados do TSE.

A vantagem de Quércia estava na máquina do PMDB em São Paulo e na ação do governo paulista a seu favor. O candidato peemedebista, apesar de ter se mostrado confiante nos debates, enfrentou denúncias de corrupção relacionadas à sua gestão como prefeito em Campinas, e em alguns momentos ficou atrás nas pesquisas, perdendo para o petebista Ermírio de Moraes, que, terminando na segunda posição com menos de 2 milhões de votos de diferença para Quércia, passou durante boa parte da campanha a imagem de um empresário moderno, preparado e capaz para gerir São Paulo.

Paulo Maluf e Suplicy pareciam fazer uma eleição à parte dos demais candidatos; o petista, que não contava com grande visibilidade, chegou a demonstrar intenção de apenas ultrapassar Maluf e ficar com a terceira posição. Para alguns petistas na época, como Hélio Bicudo, a escolha de Suplicy para concorrer ao governo paulista tinha sido equivocada, já que ele contava mais com o apoio de quadros do partido do que das bases ${ }^{162}$. Já Suplicy atribuiu sua derrota ao poder econômico de seus adversários e ao baixo tempo no horário gratuito eleitoral.

Em 1990, Suplicy declarou em entrevista que sua derrota quatro anos antes decorria também de outros fatores, “(...) como o assalto a uma agência do Banco do Brasil, em Salvador, por militantes petistas, e o episódio de Leme [cidade do interior de SP], quando o PT foi acusado falsamente de ter provocado o conflito entre polícia e boias-frias,

${ }^{161}$ Folha de S. Paulo, Primeiro Caderno, 18 de novembro de 1986, p. 7.
${ }^{162}$ Folha de S. Paulo, Primeiro Caderno, 20 de novembro de 1986, p. 6. 
que resultou na morte de duas pessoas ${ }^{163}$. Tive, ainda, problemas com segmentos do partido" ${ }^{, 164}$.

Em 1990, Plínio de Arruda Sampaio, que havia sido líder do PT na Assembleia Nacional Constituinte, foi o candidato petista ao governo paulista. Dessa vez o partido não estava sem coligação e contava com o apoio de PSB, PCdoB e PCB, partidos que nas eleições de 1986 tinham apoiado o vitorioso PMDB.

O PT, que ainda era o ícone da esquerda radical, sobrevivia essencialmente por meio das doações de seus militantes. Plínio e o PT, na reta final do primeiro turno, não tinham dinheiro em caixa para tocar a campanha pelo estado. Diante dessa dificuldade, somada a divergências dentro do partido, mais uma vez restou ao PT apenas o quarto lugar, como previam as pesquisas, atrás inclusive de Mário Covas, que concorria pelo recémcriado PSDB.

A apuração paralela de $85 \%$ das urnas, feita pela Companhia de Processamento de Dados do Município de São Paulo (Prodam), mostrava que Plínio realmente concorria mais pela terceira colocação com Covas do que pela primeira (tabela 10). Alguns chegaram a apontar que talvez a ausência de uma candidatura de Lula nessa eleição haja prejudicado o desempenho do partido.

\begin{tabular}{|c|c|c|c|c|}
\hline Região & $\begin{array}{l}\text { Votos } \\
\text { válidos } \\
\text { Maluf } \\
\text { (PDS) }\end{array}$ & $\begin{array}{c}\text { Votos } \\
\text { válidos } \\
\text { Fleury } \\
\text { (PMDB) }\end{array}$ & $\begin{array}{l}\text { Votos } \\
\text { válidos } \\
\text { Covas } \\
\text { (PSDB) }\end{array}$ & $\begin{array}{c}\text { Votos } \\
\text { válidos } \\
\text { Plínio } \\
\text { (PT) }\end{array}$ \\
\hline Capital & $35,8 \%$ & $18,3 \%$ & $14,5 \%$ & $11,1 \%$ \\
\hline Santos & $38,3 \%$ & $15,4 \%$ & $13,0 \%$ & $11,1 \%$ \\
\hline Campinas & $30,6 \%$ & $26,6 \%$ & $8,7 \%$ & $8,9 \%$ \\
\hline Bauru & $32,1 \%$ & $30,0 \%$ & $8,5 \%$ & $5,2 \%$ \\
\hline Ribeirão Preto & $29,5 \%$ & $31,4 \%$ & $7,0 \%$ & $7,4 \%$ \\
\hline $\begin{array}{c}\text { São José do Rio } \\
\text { Preto }\end{array}$ & $32,2 \%$ & $34,2 \%$ & $6,2 \%$ & $4,3 \%$ \\
\hline Presidente Prudente & $35,4 \%$ & $29,2 \%$ & $6,5 \%$ & $3,8 \%$ \\
\hline
\end{tabular}

\footnotetext{
${ }^{163}$ O governador de São Paulo, Franco Montoro (PMDB), chegou a dizer que "Os conflitos trabalhistas não podem ser resolvidos com intransigência dos poderosos ou a provocação dos agitadores. A nação repele as invasões, os assaltos a agências bancárias e a promoção de agitações". Ver https://www.youtube.com/watch?v=EmFyyXX7jdQ.

${ }_{164}$ Ver http://csbh.fpabramo.org.br/o-que-fazemos/editora/teoria-e-debate/edicoes-anteriores/nacionalentrevista-com-eduardo-suplicy-vit.
} 


\begin{abstract}
*As principais cidades de cada região eram: 1) Capital (Grande São Paulo e regiões de Sorocaba, S. José dos Campos e Taubaté); 2) Santos (Cubatão e litoral do estado); 3) Campinas (Jundiaí, Limeira, Leme, Americana, Rio Claro e Amparo; 4) Bauru (regiões de Marília, Lins, Jaú, Avaré e Botucatu); 5) Ribeirão Preto (regiões de Barretos, Franca, São Carlos, Jaboticabal e Bebedouro); 6) S. J. do Rio Preto (Araçatuba, Catanduva, Birigui e Jales; 7) Presidente Prudente (regiões de Andradina, Assis, Adamantina e Presidente Venceslau.

Fonte: elaboração da autora a partir de dados divulgados na Folha de S. Paulo em 12/10/1990.
\end{abstract}

Nas eleições de 1994, José Dirceu foi o primeiro petista a concorrer ao governo paulista e a ficar entre os três primeiros colocados, ultrapassando o PMDB, que tinha sido o principal rival nas eleições anteriores. Nesse ano, o PT ganhou espaço com a derrocada do PMDB paulista, bem como com a ausência de candidatura do PDS, partido de Maluf. Contudo, mais espaço com a decadência peemedebista em São Paulo ganhou o PSDB de Mário Covas, que sendo o grande vitorioso no segundo turno em 94 contra o candidato do PDT, tornar-se-ia o principal adversário a ser batido.

Ao ficar na terceira posição, com mais de 4 milhões de votos atrás de Covas, o PT, apesar da resistência de sua ala mais radical, foi um dos apoiadores do PSDB no segundo turno paulista, ideia defendida por Lula, que, adotando um tom moderado, disse que se deveria "levar em consideração o passado político de Covas". Na época, a negociação da aliança, que previa a interferência petista no programa de governo tucano, foi mediada pelo presidente do PT em São Paulo, Arlindo Chinaglia, e pelo candidato a vice de Covas e também presidente do PSDB paulista, Geraldo Alckmin; somem-se a isso os encontros entre Lula e Covas.

O PSDB e Covas receberam idêntico apoio do PT nas eleições seguintes, no segundo turno em 1998, quando a candidata Marta Suplicy repetiu a terceira colocação de Dirceu, embora tenha se aproximado mais do que este do segundo colocado ${ }^{165}$. Nesse ano, o apoio do PT ao PSDB ficou condicionado ao compromisso público assumido por Covas em adotar pelo menos um dos programas sociais defendidos pelos petistas.

Assim como as demais campanhas petistas, a de Marta foi prejudicada pela falta de recursos do partido; a dois dias da eleição, inexistia material de propaganda para distribuir entre os militantes, sem contar a falta de outdoors, que tinham ficado expostos por apenas poucos dias. Apesar disso, a petista manteve os redutos conquistados nas

\footnotetext{
${ }^{165} \mathrm{Na}$ época, houve rumores de que o desempenho eleitoral de Marta foi prejudicado pela manipulação de pesquisas de opinião pouco antes da eleição, o que minou a possibilidade da sua chegada ao segundo turno. Ver http://www.cartacapital.com.br/politica/relembrando-uma-pesquisa-na-eleicao-paulista-de-1998.
} 
eleições anteriores pelo PT, como os municípios de Araraquara, Diadema, Santo André e Sorocaba, obtendo uma votação total de $22,51 \%$, conforme evidencia a tabela 11 .

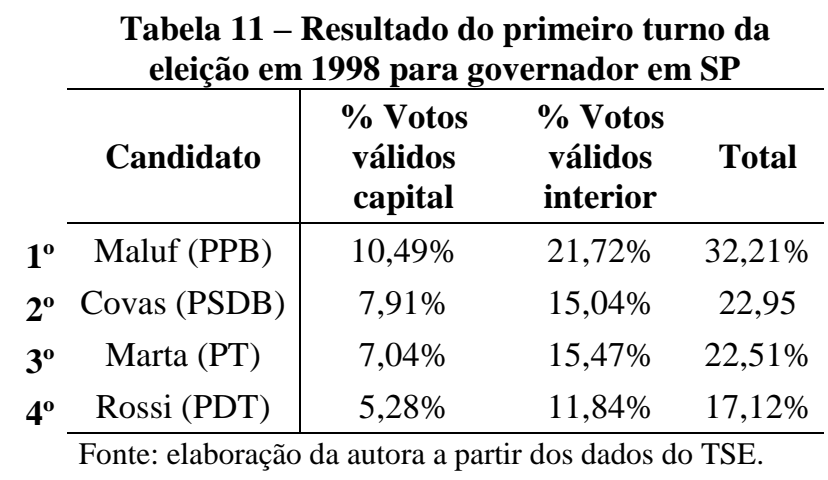

O apoio de Marta e do PT ao PSDB nas eleições de 98, foi retribuído por Covas quando a petista concorreu à prefeitura da capital, dois anos depois, em 2000, ano em que Alckmin, primeira opção de Covas, havia perdido no primeiro turno. $\mathrm{O}$ gesto indicava uma possível futura parceria entre PT e PSDB no estado. Marta, anos depois, quando se elegeu prefeita de São Paulo, chegou a convidar Stela Goldenstein, que tinha sido membro da equipe de Covas no governo estadual, para assumir a Secretaria Municipal de Meio Ambiente. Naquele momento, Covas havia se consolidado como a principal liderança do PSDB tanto em São Paulo quanto nacionalmente, e em seu estado funcionava como um intermediador entre tucanos e petistas, conforme já apontado anteriormente.

Covas tinha um bom relacionamento com figuras importantes do PT e conseguiu o apoio do partido em suas duas eleições para governador. A aliança entre os dois partidos nascidos em São Paulo mostrara-se viável mesmo antes do apoio à Marta na capital. Já nas eleições presidenciais em 1989, o PSDB, com a derrota de Covas, apoiou Lula contra Collor no segundo turno. Com a morte de Covas em 2001, o PSDB ficou órfão, e com ele morreu uma possível cooperação com o PT.

A política paulista desde meados dos anos 90, com a decadência do PMDB no estado, sustentava-se em Covas, Maluf e o PT. Sem Covas o PSDB perdeu quem dava as cartas e, ao mesmo tempo, a unidade ao tucanato, o que deu início a uma luta interna entre membros do partido pela herança covista. O PSDB não chegou a esfacelar, mas estremeceu e viu diminuída a homogeneidade que certamente o favorecia eleitoralmente tanto em São Paulo quanto no Brasil. 
Enquanto as lideranças psdebistas disputavam internamente o espaço e a influência que tinham sido deixados por Covas, o PT, que já estava em ascensão, ampliou a sua entrada nos estados e em âmbito nacional. Em São Paulo, viu-se beneficiado tanto pela crise vivida pelos tucanos quanto pela decadência do malufismo. Foi nesse contexto que, no segundo turno das eleições de 2002, Lula foi eleito presidente da República, derrotando José Serra do PSDB, inclusive em São Paulo, onde recebeu 55,39\% dos votos válidos.

Inédita também foi a ida para o segundo turno na eleição para o governo paulista de José Genoíno, petista que, enfrentando Geraldo Alckmin, obteve 4 milhões e meio de votos a mais do que Marta Suplicy em 1998. A chamada "onda Lula" nessa eleição certamente contribuiu para o desempenho de Genoíno em SP, mas não foi suficiente para a vitória, que ficou novamente com os tucanos. Genoíno, apoiado pelo PCdoB e por setores pequenos e isolados do PMDB, PDT e PSB, contou ainda com a derrocada de Maluf, candidato que era tido como favorito para avançar na disputa com Alckmin.

Em 2006, Aloizio Mercadante, senador paulista mais votado nas eleições de 2002, foi o nome do PT para disputar o governo paulista. O candidato governista e favorito para a vitória era o tucano José Serra, e a disputa contou também com Orestes Quércia, exgovernador que tentava com sua candidatura firmar novamente o PMDB em São Paulo. Embora Mercadante tenha recebido no primeiro turno mais votos (6.771.582) do que Genoíno em 2002 (6.361.747), isso não foi suficiente para barrar o sucesso de Serra ainda no primeiro turno com uma votação recorde.

O PT, novamente segundo colocado, foi acusado durante a campanha de participar de um esquema para prejudicar a candidatura psdebista, conluio que envolvia a compra de um dossiê contra Serra com informações sobre ilegalidades supostamente cometidas por ele quando ministro da Saúde do governo FHC, o que pode ter prejudicado em alguma medida o seu desempenho eleitoral. Ressalta-se que em 2005 o partido e seus candidatos tiveram ainda a imagem arranhada pelo escândalo do mensalão.

A tabela 12, abaixo, mostra a votação em 2006 de Serra e Mercadante por região administrativa de São Paulo. Nota-se que a região metropolitana e a da Baixada Santista são as únicas em que a diferença entre a votação de ambos os candidatos não ultrapassa os $16 \%$, o que evidencia, apesar da perda, maior penetração de Mercadante e do PT nos municípios que compõem essas localidades. 


\begin{tabular}{|c|c|c|c|}
\hline & $\begin{array}{c}\text { Região } \\
\text { administrativa }\end{array}$ & $\begin{array}{l}\text { Votos válidos } \\
\text { José Serra }\end{array}$ & $\begin{array}{c}\text { Votos válidos } \\
\text { Aloizio } \\
\text { Mercadante }\end{array}$ \\
\hline 1 & Central & $65,24 \%$ & $25,20 \%$ \\
\hline 2 & Baixada Santista & $52,85 \%$ & $37,10 \%$ \\
\hline 3 & Araçatuba & $68,91 \%$ & $24,89 \%$ \\
\hline 4 & Barretos & $68,13 \%$ & $23,84 \%$ \\
\hline 5 & Bauru & $68,79 \%$ & $23,51 \%$ \\
\hline 6 & Campinas & $60,19 \%$ & $31,00 \%$ \\
\hline 7 & Franca & $61,28 \%$ & $19,20 \%$ \\
\hline 8 & Marília & $69,90 \%$ & $23,26 \%$ \\
\hline 9 & Presidente Prudente & $66,88 \%$ & $27,26 \%$ \\
\hline 10 & Registro & $69,35 \%$ & $24,47 \%$ \\
\hline 11 & Ribeirão Preto & $66,71 \%$ & $25,09 \%$ \\
\hline 12 & São José do Rio Preto & $68,58 \%$ & $21,98 \%$ \\
\hline 13 & São José dos Campos & $65,04 \%$ & $26,86 \%$ \\
\hline 14 & Sorocaba & $67,09 \%$ & $24,84 \%$ \\
\hline 15 & Metropolitana & $51,55 \%$ & $36,29 \%$ \\
\hline
\end{tabular}

Fonte: elaboração da autora a partir dos dados do TSE.

Pela primeira vez, em 2010, o PT repetiu um nome para a disputa em São Paulo: Mercadante concorreu novamente, agora contra o psdebista Geraldo Alckmin. A tática de repetir a candidatura para maximizar as chances de sucesso eleitoral deu quase certo para o PT, já que Mercadante obteve mais de 1 milhão de votos acima da votação recebida por ele em 2006, o que correspondeu à maior votação da história do partido em SP no primeiro turno. Com esse resultado, por apenas $0,2 \%$ dos votos Mercadante não levou a disputa para o segundo turno.

A participação de Lula na campanha em SP foi um fator que deve ser considerado para o bom desempenho do PT nessa eleição, assim como teve importância nos anteriores, quando o partido ganhou expressão nacional e o cargo de presidente da República. Como exemplo, a propaganda de Mercadante na TV em 2010 retratou sua importância no governo Lula, como senador, e fez questão de explicitar a relação de confiança dos dois petistas ao longo de mais de trinta anos. Em um dos programas, Lula, logo no início, disse: “O Mercadante é, sem dúvida, uma das pessoas mais preparadas desse país. Eu me lembro que em 2002, eu convidei ele para ser ministro e ele disse "Presidente, você vai precisar muito mais de mim lá no Senado". E graças a ele a gente 
conseguiu um bocado de vitórias" E completou: "Eu gostaria que você depositasse no Mercadante a mesma confiança que depositou em mim. Estou cada vez mais convencido de que, assim como mudamos o Brasil para melhor, o Mercadante vai conseguir fazer o mesmo em São Paulo"166.

No entanto, a ajuda de Lula em 2014 na campanha de Alexandre Padilha como candidato do PT ao governo paulista não surtiu o efeito esperado e o partido viu o seu desempenho eleitoral em São Paulo retroceder ao que era entre os anos 80 e 90. Certamente por prever o desconhecimento que a população paulista apresentaria em relação a Padilha, Lula, no programa eleitoral do candidato, apelou não para a imagem de Padilha, mas para a história do partido e para os investimentos que o governo federal petista fez em São Paulo, apontando que “(...) a grandeza desse partido são os milhões de seres humanos anônimos que nunca apertaram a mão da gente, e que acreditam que nós somos o partido deles".

O discurso de apelo social não foi suficiente para tornar viável a candidatura de um político desconhecido que nunca havia concorrido a nenhum cargo eletivo, e também não minimizou os efeitos da crise que se iniciou para o PT nacional em 2012, quando Dirceu, Genoíno e o ex-tesoureiro do PT, Delúbio Soares, foram presos por corrupção ativa e formação de quadrilha, como resultado do escândalo do mensalão que explodiu em 2005. Além disso, não abafou o escândalo da Petrobras que veio à tona no próprio ano eleitoral e implicou o PT no recebimento de propina advinda de contratos firmados pela estatal.

O resultado desse contexto para o PT paulista foi o terceiro lugar de Padilha nas eleições, com a conquista de menos de 4 milhões de votos (18,22\% dos votos válidos), ficando atrás até mesmo do candidato peemedebista, Paulo Skaf.

Outro fator ao qual se pode atribuir o mau desempenho do PT nessa eleição é o crescimento da rejeição do eleitor paulista ao partido. Segundo reportagem de Valdo Cruz publicada na Folha de S. Paulo ${ }^{167}$, o PT, especialmente em São Paulo, foi em 2014 relacionado "(...) a escândalos, com os principais quadros presos devido ao mensalão, e a uma política econômica que gerou inflação alta e baixo crescimento", o que pesou tanto para o setor empresarial quanto para os trabalhadores da indústria, que sofreram com demissões.

\footnotetext{
${ }^{166}$ Ver programa eleitoral em https://www.youtube.com/watch?v=MnBuo dV1x4.

${ }^{167}$ Folha de S. Paulo, Eleições 2014, 6 de outubro de 2014, p. 7.
} 
O resultado em São Paulo foi ruim até mesmo para a presidente e candidata à reeleição, Dilma Rousseff, que no estado recebeu somente $26 \%$ dos votos válidos, ao passo que seu principal adversário, Aécio Neves (PSDB), obteve 44\%. Diante da perda no maior colégio eleitoral do país, Dilma refez sua estratégia, visando melhorar a comunicação com os paulistas.

\subsection{O balanço do PT em São Paulo: progresso e retrocesso}

Em 1982, quando houve a primeira eleição direta nos estados para a escolha do governador desde os anos $1960^{168}$, o PT iniciou sua luta para chegar ao poder no estado de São Paulo. É evidente que de lá para cá o apoio da população paulista aos candidatos petistas nas urnas teve um aumento considerável, com exceção nas eleições de 2014, na qual Alexandre Padilha ficou na terceira colocação da disputa, fato que não ocorria desde as eleições de 1998, conforme evidenciado na tabela abaixo:

Tabela 13 - Desempenho do Partido dos Trabalhadores na disputa para o governo de São Paulo (1982-2014)

\begin{tabular}{|c|c|c|c|c|}
\hline Turno & Ano & Candidato & $\begin{array}{c}\text { \% Votos } \\
\text { válidos }\end{array}$ & $\begin{array}{l}\text { Colocação } \\
\text { na disputa }\end{array}$ \\
\hline $1^{\circ}$ turno & 1982 & Lula & 10,8 & $4^{\circ}$ \\
\hline $1^{\circ}$ turno & 1986 & Eduardo Suplicy & 11,03 & $4^{\circ}$ \\
\hline $1^{\circ}$ turno & 1990 & Plínio Sampaio & 12,12 & $4^{\mathrm{o}}$ \\
\hline $1^{\circ}$ turno & 1994 & José Dirceu & 14,86 & $3^{\circ}$ \\
\hline $1^{\circ}$ turno & 1998 & Marta Suplicy & 22,51 & $3^{\circ}$ \\
\hline $1^{\circ}$ turno & 2002 & José Genoíno & 32,44 & $2^{\circ}$ \\
\hline $2^{\circ}$ turno & 2002 & José Genoíno & 41,36 & $2^{o}$ \\
\hline $1^{\circ}$ turno & 2006 & Aloizio Mercadante & 31,68 & $2^{\circ}$ \\
\hline $1^{\circ}$ turno & 2010 & Aloizio Mercadante & 35,23 & $2^{\circ}$ \\
\hline $1^{\circ}$ turno & 2014 & Alexandre Padilha & 18,22 & $3^{\circ}$ \\
\hline
\end{tabular}

Quando o PT concorreu pela primeira vez para o governo de São Paulo com Lula, no início dos anos 80, o partido pecou pelo excesso de agressividade no discurso de Lula, e certamente por isso não obteve um resultado animador. Talvez o eleitorado paulista tenha se sentido acuado, ou pelo menos intrigado com o discurso radical estabelecido pelo PT e por Lula, que, embora fosse um candidato de expressão - o oposto do que seria um

${ }^{168}$ Os estados realizaram eleições alternadas para governador entre os anos de 1962 e 1965. 
"picolé de chuchu" -, passava uma imagem, inclusive física, um tanto extravagante, o que pode explicar, em parte, suas três derrotas consecutivas para a Presidência da República $(1989,1994$ e 1998).

Se a imagem traz consigo uma informação, o candidato petista em 1982 parecia ser um louco radical e, diante da experiência da ditadura, ficava a dúvida se seria benéfico ir de um extremo ao outro. Além disso, somada à sua radicalidade, a sua origem não the era favorável eleitoralmente: sua baixa escolaridade o destacava como despreparado para governar. Por fim, o despreparo do PT em sua primeira eleição se manifestou quando deixou as atividades eleitorais a cargo de intelectuais como Francisco Weffort, Frei Beto e José Dirceu, marginalizando da campanha políticos com expertise política para caçar votos.

Com efeito, ao que parece, em 1982 o PT em SP não tinha uma candidatura viável, pois o discurso estabelecido e a imagem de seu candidato não permitiam, o que era agravado pelo fato de a campanha eleitoral ser guiada mais por doutores e militantes do que por indivíduos experientes no jogo político.

Em 1986, Eduardo Suplicy foi o candidato do PT ao governo paulista e, diferentemente de Lula em 1982, possuía um tom menos agressivo e foi a aposta de parte significativa dos quadros do partido. Embora o PT se colocasse como uma alternativa aos grandes partidos com candidatos diferentes dos velhos políticos, a sua imagem, difundida pelos meios de comunicação e adversários, era de agitador e baderneiro. Sem visibilidade, obteve, e mesmo contando com um bom apoio do eleitorado dos grandes centros industriais de São Paulo, Suplicy não passou do quarto lugar conquistado também por Lula em 82.

Posição idêntica à do petista Plínio Salgado nas eleições de 1990, que, embora tivesse uma eleição quase garantida para a Câmara Federal, foi a aposta do PT em São Paulo principalmente por sua trajetória política. Nesse ano, o partido tinha maiores esperanças eleitorais no estado, tendo em vista que, em 1986, conseguira eleger Lula como o deputado federal mais votado no Brasil e, em 88, havia ganhado a prefeitura da capital paulista com a candidatura de Luíza Erundina. Além disso, em 1989, Lula foi ao segundo turno com Fernando Collor (PRN), na disputa para a presidência da República. No entanto, o embalo eleitoral do PT não se repetiu na disputa para o governo paulista. 
José Dirceu em 1994 e Marta Suplicy em 1998 foram os primeiros candidatos petistas a galgar uma posição acima do quarto lugar do partido nas eleições anteriores: ambos ficaram na terceira colocação na disputa para o governo paulista. Marta, confirmando a tendência de evolução eleitoral do PT paulista desde 1982, recebeu mais votos que Dirceu. Ressalta-se, no entanto, que o crescimento do PT entre essas eleições decorreu também da saída e da entrada de candidatos e partidos da disputa, como ocorreu em 1994, quando o partido se beneficiou da queda do PMDB paulista e da ausência do PDS de Maluf.

Mesmo apresentando certo progresso, os candidatos petistas até o momento não contavam com grande visibilidade e imputavam sua derrota ao pouco tempo de propaganda eleitoral na TV e no rádio ou aos baixos recursos econômicos de que o partido dispunha para fazer uma campanha de peso ante os demais. É provável que tais fatores tenham comprometido o desempenho eleitoral do PT até 1998 em São Paulo. Todavia, deve-se considerar que, somada à má reputação do partido cultivada principalmente nos anos 80 , a sua deficiência no estado pode ser avaliada pela inexpressividade de seus candidatos, que sempre eram diferentes entre os pleitos.

No início dos anos 90, o principal adversário a ser enfrentado pelo PT, que estava em ascensão, havia mudado: não era mais o PMDB, mas sim o PSDB de Mário Covas, que, ao vencer a eleição para o Poder Executivo paulista em 1994, consolidou-se como uma das principais, se não a principal liderança tucana. Entretanto, Covas, famoso por sua capacidade de articulação política, conseguiu o apoio do PT no segundo turno das suas duas eleições para governador, o que indicava, no futuro, a possibilidade de os dois partidos trabalharem juntos, pelo menos no estado.

Em 2001, a morte do líder tucano foi também a morte dessa possível interlocução. O PT, diante do abalo do PSDB, ganhou espaço eleitoral nacionalmente, o que resultou na vitória de Lula ao Planalto e no segundo turno inédito de José Genoíno em SP. Nesse sentido, não seria exagerado dizer que a morte de Covas representou um daqueles incidentes que influem significativamente no curso da história política de um país. A expressividade do candidato petista ao governo paulista se deveu muito à visibilidade positiva que Lula ganhou naquele ano e, mesmo com a nova derrota, serviu para o partido crescer. 
A ascensão do PT entre 2002 e 2010 certamente colaborou para a segunda colocação na disputa pelo governo paulista do petista Aloizio Mercadante nas eleições de 2006 e 2010. Desde 2002 o PT já não sofria mais com escassez de recursos financeiros para realizar campanha em São Paulo e, portanto, essa já não poderia ser uma justificativa para a derrota no estado. Mercadante, tendo Lula atrelado à sua imagem, tinha uma visibilidade considerável entre o eleitorado e representou uma candidatura viável, assim como tinha sido Genoíno em 2002.

Mesmo com o crescimento eleitoral do PT no início dos anos 2000, era nítido que seus candidatos em São Paulo precisavam se apoiar em uma figura maior, no caso, Lula, e na expressão nacional do partido como um todo para se sustentarem como alternativas ao PSDB. Diferentemente, os candidatos paulistas - Covas, Alckmin e Serra tinham candidaturas dotadas de certa independência, sendo muitas vezes eles que contribuíam em peso com a campanha do partido no âmbito nacional, e não o contrário.

Nas últimas eleições de 2014, a pouca visibilidade de Alexandre Padilha como candidato do PT ao governo de São Paulo não foi superada pela participação de Lula nos programas eleitorais ou por sua presença em eventos pelo estado. Somado ao desconhecimento de Padilha, juntou-se, em prejuízo do PT, a crise pela qual o partido passou em âmbito nacional, sendo envolvido em escândalos de corrupção, que já tinham culminado em 2012 com a condenação de integrantes de sua antiga cúpula, a exemplo de José Dirceu e José Genoíno.

O PT, antes tido como o partido que criticava a velha política, como fez Lula arduamente em 1982, e apontava os envolvidos em corrupção, passou, de acordo com as denúncias e investigações, a fazer parte dos esquemas que tanto criticou em outros governos, o que certamente desagradou a muitos de seus eleitores. A insatisfação com o PT em São Paulo, não sendo um fenômeno recente e tampouco insignificante, fez com que o estado onde o partido nasceu haja se convertido num reduto do antipetismo, sentimento promovido sobretudo por meios de comunicação que possuem forte influência entre os paulistas.

Reportagem da jornalista Julia Duailibi publicada na edição número 106 da Revista Piauí ${ }^{169}$ mostra, por exemplo, que a rádio Jovem Pan funciona em São Paulo como uma voz antipetista, papel que ganhou notoriedade principalmente nos últimos anos. No ar

169 "A nova sinfonia paulistana: como a rádio Jovem Pan se reinventou ao dar voz para o sentimento antipetista em São Paulo” por Julia Duailibi. Revista Piauí, n. 106, ano 9, julho, 2015, p. 16-25. 
há sete décadas, a Jovem Pan, que nasceu com o nome de Rádio Panamericana, sempre foi, segundo Duailibi, mais inclinada a falar para a classe média paulista, popularizando-se de início por seus programas direcionados às populações estrangeiras localizadas em São Paulo, e depois por aqueles dedicados a locuções esportivas.

Hoje, após experimentar um período de decadência, a rádio se restabeleceu no topo da audiência graças à ideia de seu atual presidente de transformar em publicidade o aumento da insatisfação com o PT. Os programas Jornal da Manhã e Os Pingos nos Is, carros-chefes da rádio atualmente, contando com apresentadores polêmicos e abertamente contrários ao PT - Rachel Sheherazade, Joseval Peixoto, Marco Antonio Villa e Reinaldo Azevedo -, disseminam opiniões “(...) invariavelmente de oposição ao governo petista e quase sempre ultraconservadoras, na linha 'bandido bom é bandido morto" ${ }^{\prime 170}$.

A ideia do presidente, Antonio Augusto Amaral de Carvalho Filho, o Tutinha, de reformular sua rádio nesse sentido, investindo em programas estilo talk radio contrários ao PT, foi uma inspiração norte-americana. Duailibi explica que nos últimos dez anos, as rádios perderam nos Estados Unidos, graças ao advento das novas tecnologias, a função de veículos musicais. Diante disso, para se manter vivas, investiram em programas jornalísticos, em sua maioria conservadores, contrários aos democratas ${ }^{171}$ e à gestão de Barack Obama. "O formato dos programas é sempre o mesmo: um apresentador polêmico comenta as notícias do dia, enquanto recebe ligações dos ouvintes" ${ }^{\prime 172}$.

Com a emergência do escândalo do mensalão no final do primeiro mandato do ex-presidente Lula, o PT deixou de ser identificado como um partido da ética e perdeu, como principal representante da esquerda no Brasil, o que o jornalista Otavio Frias Filho chamou de "hegemonia moral". Essa perda foi agravada pelo envolvimento do partido e de seus quadros em outras denúncias de corrupção que vieram à tona nos mandatos posteriores, o que legitimou, segundo Duailibi, os discursos cada vez mais inflamados de comentaristas de direita nos meios de comunicação.

\footnotetext{
${ }^{170}$ Idem, p. 16.

${ }^{171}$ Duailibi conta na reportagem que "Em junho [de 2015], a candidata democrata Hillary Clinton sugeriu que a 'retórica inflamada' das talk rádios poderia ser o gatilho de massacres que ocorrem pelo país, como o de Charleston, onde nove negros foram mortos por um jovem branco". Rush Limbaugh, apresentador do conhecido talk radio conservador The Rush Limbaugh Show respondeu: "É a linguagem da esquerda que está destruindo a fé das pessoas no futuro. É a linguagem da esquerda, de seus intelectuais e de seus cientistas, que está dando às pessoas ideias apocalípticas” (p. 23).

${ }^{172}$ Idem, p. 22. "Esse tipo de programa se tornou possível em 1987, com o fim da Fairness Doctrine, lei que determinava às emissoras que dessem tratamento igualitário a diferentes pontos de vista".
} 
Na Jovem Pan, após as manifestações do dia 15 de março de 2015, Villa, apresentando o Jornal da Manhã, ao referir-se ao governo federal, "defendeu a expulsão do poder 'desses criminosos de lesa-pátria que nos governam"', e citando os protestos a favor do impeachment de Dilma, afirmou que ela estava “(...) mais perdida que o Lula em biblioteca" 173 .

Na mesma linha de seu colega de bancada, Sheherazade, que se autodenomina "conservadora como a maioria da população brasileira", ataca o PT, embora amenize o discurso com relação a outros partidos: "O partido [referindo-se ao PMDB] se desgastou por demais, andando de braços dados com o sujo Partido dos Trabalhadores. Tem um ditado que minha avó dizia: quem anda com porco, farelo come"174.

Joseval Peixoto, companheiro de Villa e Sheherazade, em entrevista a Duailibi, embora se diga incomodado com seu programa ter virado uma "trincheira contra o PT", aponta que o público da Jovem Pan é anti-PT e reconhece que “(...) o surgimento da direita no jornalismo até demorou. Principalmente no nosso estado [São Paulo], onde o PT sempre foi derrotado" $" 175$.

A propaganda negativa desse tipo contra o PT também é a pauta do jornalista Reinaldo Azevedo, criador do adjetivo "petralha" e apresentador de Os Pingos nos Is, uma extensão radiofônica do blog que ele mantém há dez anos no site da revista Veja, que é referência dos oposicionistas ao PT. Azevedo se refere ao "petismo" e a outras variações da esquerda como "doenças do espírito", e é enfático no ataque a Lula: "É impressionante que o Brasil tenha produzido essa monstruosidade política disfarçada de operário bonachão e bom camarada"

Se se considera a influência que os meios de comunicação exercem sobre as opiniões do eleitor, interferindo, portanto, na sua tomada de decisão, certamente a rádio Jovem Pan e outros veículos de comunicação que se colocam abertamente contra o PT têm grande peso na disseminação do sentimento antipetista em São Paulo e no Brasil, colaborando para os resultados eleitorais negativos do partido e de seus candidatos. Vários estudos e experimentos apontam que a esfera midiática possui preponderância suficiente

\footnotetext{
${ }^{173}$ Idem, p. 18

${ }^{174}$ Idem, p. 18.

${ }^{175}$ Idem, p. 19.

${ }^{176}$ Idem, p. 23.
} 
para provocar efeitos cognitivos e didáticos sobre o seu público (WEBER, 1990; LIMA, 2001).

No Brasil, o rádio é, depois da TV, o meio de comunicação mais acessado, embora seu uso entre os brasileiros tenha caído nos últimos dois anos de $61 \%$ para 55\%, de acordo com dados da Pesquisa Brasileira de Mídia, realizada pelo Ibope. Especificamente a rádio Jovem Pan, eleita nos anos 90 "a cara de São Paulo", contando com uma rede de cem afiliadas, está presente em 2.500 cidades, e nos meses que antecederam as eleições de 2014 sua frequência AM foi a segunda maior em São Paulo, atrás apenas da Rádio Bandeirantes $\mathrm{AM}^{177}$.

Com o slogan "informação e prestação de serviço" por meio de um “jornalismo sério, com responsabilidade e isenção", a Jovem Pan foi criada com foco em São Paulo e, segundo Duailibi, “(...) flertava com o malufismo e nunca foi uma voz de oposição ao regime militar" ${ }^{\prime 17}$. De acordo com um ex-executivo da rádio, a ideia do atual presidente de transformar sua emissora em uma voz de oposição ao PT veio da “(...) soma de duas coisas: "uma exacerbação ideológica, por questões de mercado, e a defesa da posição política em que eles [herdeiros da rádio], de fato, acreditam"179.

No entanto, colocar-se como uma das vozes da oposição ao PT no Brasil custou à Jovem Pan menos 12 milhões de reais advindos de publicidade do governo federal ou de estatais, segundo informações do próprio presidente da emissora a integrantes da equipe. Duailibi observa: “A Petrobras, por exemplo, que nesse ano [2015] já gastou 2 milhões de reais com rádios, alocou apenas 20 mil na Pan" ${ }^{\text {180 }}$. Ao passo que os anúncios do governo federal e de seus órgãos são escassos na rádio, as propagandas da Sabesp e do Metrô paulista, entidades ligadas ao governo estadual tucano, são veiculadas recorrentemente. Duailibi salienta que até junho de 2015 o Metrô já tinha investido 235 mil reais na Jovem Pan, encomendando anúncios bem como "publieditoriais", isto é, reportagens feitas pelos repórteres da rádio exaltando a empresa.

Coincidência ou não, o governo psdebista em São Paulo também se aproxima da Pan no uso e no elogio da imagem do paulista trabalhador. Desde os anos 70, o Jornal da Manhã abre com "Amanhecendo", canção que faz parte da Sinfonia Paulistana,

\footnotetext{
${ }^{177}$ Ver http://www.radios.com.br/relatorios/stat_2014-09_amfmestado_33-25.

178 Idem, p. 21.

${ }^{179}$ Idem, p. 21.

${ }^{180}$ Idem, p. 22.
} 
composta por Billy Blanco: "Começou um novo dia, já volta/ Quem ia, o tempo é de chegar/ De metrô chego primeiro, se tempo é dinheiro/ Melhor, vou faturar/ Sempre ligeiro na rua, como quem sabe o que quer/ Vai o paulista na sua, para o que der e vier". O refrão é marca registrada: "Vambora, vambora/ Olha a hora, vambora". Para Duailibi, a canção “(...) funciona como uma versão mais elaborada de um apito de fábrica, exortando quem a

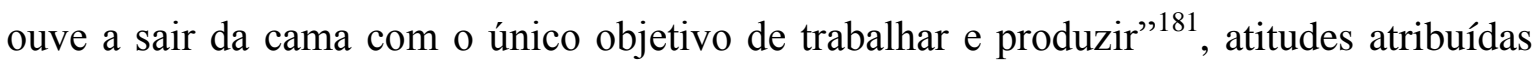
aos paulistas também por Alckmin em seus discursos, conforme apontado anteriormente.

Esse não é, todavia, o único ponto em comum entre Alckmin e a Jovem Pan. A rádio, que financia comentaristas anti-PT, demonstra certa simpatia pelo governador do estado, que é afastado dos posicionamentos críticos; estes recaem em sua grande maioria sobre Lula, Dilma e Haddad.

Nas eleições de 2014, o petista Alexandre Padilha também foi alvo dos comentários críticos de Reinaldo Azevedo. Comentando o debate entre os candidatos ao governo paulista ocorrido na Globo em 30 de setembro ${ }^{182}$, Azevedo disse que a ocasião "foi a frente dos seis contra um" e vitimizou Alckmin e seu governo em relação aos "ataques" de seus adversários. Minimizando a relevância dos representantes dos partidos nanicos, centrou suas críticas em Padilha, nas suas palavras, "membro do PT sem ser trabalhador", e no peemedebista Skaf, segundo ele, "presidente licenciado da Fiesp sem ser empresário". Qualificou o debate como um "show de horrores", mas não da parte de Alckmin, e afirmou que era para "estômagos fortes" ouvir do candidato petista e do peemedebista lições contra a corrupção, depois de vir à tona o escândalo da Petrobras.

Acrescentou que "ouvir de Padilha lições sobre segurança pública, dados os desastres colhidos na área por seu partido no país e nos estados em que é governo, seria de gargalhar não fosse o tédio". Chamou de "afirmação tecnicamente estúpida" e de "asnice" as críticas dos concorrentes de Alckmin contra a Sabesp e isentou o governo tucano da responsabilidade pela crise de abastecimento de água no estado, a qual, segundo ele, afetava apenas oito cidades localizadas no estado. Em comentário anterior sobre as pesquisas de voto em São Paulo, Azevedo já tinha dito que "o discurso da seca [era] uma secura de votos" $" 183$ para Padilha e Skaf. Finalizou dizendo que as pesquisas constatavam a

\footnotetext{
${ }^{181}$ Idem, p. 20.

${ }^{182}$ Ver comentário completo em http://front1.jovempan.com.br/opiniao-jovem-pan/comentaristas/reinaldoazevedo/candidatos-em-sp-se-juntam-contra-geraldo-alckmin.html.

183 Ver comentário em http://front1.jovempan.com.br/opiniao-jovem-pan/comentaristas/reinaldoazevedo/skaf-e-padilha-tem-muito-lamentar-com-numeros-de-pesquisa-em-sao-paulo.html.
} 
vitória do tucano já no primeiro turno, e justificou: “O debate de ontem da Rede Globo demonstrou por quê".

A conclusão à qual se chega é a de que o Partido dos Trabalhadores em São Paulo, em 32 anos de competição no estado, ao todo nove eleições, não foi capaz de lançar candidatos ao Executivo estadual que fossem vistos pelo eleitorado como opções viáveis, e tampouco de organizar uma máquina partidária que sustentasse as candidaturas e a formação de alianças.

Considerando o PT como variável isolada na análise das vitórias tucanas, os candidatos petistas, quando não tinham problemas relacionados à sua imagem - expressiva ou inexpressiva demais -, ou foram prejudicados pela falta de recursos do partido para a realização da campanha ou foram alvo de ataques dos meios de comunicação, os quais não atingiam os candidatos governistas; ou, ainda, pecaram pelo uso excessivo de muletas eleitorais, uma em especial: a figura do então presidente Lula, principalmente quando ele passou pela grande transformação que o conduziu ao Planalto em 2002. 


\section{CONSIDERAÇÕES FINAIS}

O sucesso eleitoral do PSDB e de seus candidatos ao governo do estado de São Paulo é um fato que vem de longa data, ultrapassando vinte anos de poder ininterruptos. Desde a vitória de Mário Covas no pleito estadual de 1994, o partido conquistou seis mandatos consecutivos - o último com a vitória de Geraldo Alckmin em primeiro turno, com mais de 12 milhões de votos nas eleições de 2014. Tendo em vista a complexidade que ronda a arena política bem como os resultados eleitorais, este estudo se propôs a contribuir com a discussão acerca das reeleições no Brasil, em especial sobre a manutenção do poder pelo PSDB no governo de São Paulo, por meio do tucano Geraldo Alckmin.

Foram trabalhados quatro fatores que, juntos, acredita-se poderem explicar, ainda que minimamente, as três vitórias de Alckmin em São Paulo (2002, 2010 e 2014). Primeiramente, foi analisada a distribuição geográfica das votações do candidato no estado, buscando identificar redutos eleitorais psdebistas. A seguir, partindo da literatura que tem as clivagens sociais como relevantes para a estruturação das organizações partidárias bem como de suas bases de apoio, procurou-se verificar o peso de indicadores socioeconômicos na explicação das proporções de votos recebidas por Alckmin nos municípios. Após a consecução de um modelo logístico linear generalizado (GLM) para cada ano eleitoral, utilizando-se como variáveis independentes anos de estudo, IDHMRenda, Gini, índice de envelhecimento, entre outras, os resultados obtidos mostraram a significância estatística de alguns desses índices.

Nos três anos, escolaridade, renda e grau de envelhecimento da população mostraram-se importantes para compreender as votações do tucano. Com exceção do índice educacional utilizado no modelo de 2014, todos esses indicadores tiveram o mesmo efeito nas três votações, apontando a tendência de Alckmin em receber maior votação nos municípios com menor nível educacional, menor renda e população mais idosa. Embora não seja possível utilizar tais dados para explicar o comportamento do eleitor, já que se trata de informações agregadas por município, deve-se ressaltar que esses resultados vão ao encontro das características do eleitor típico de Alckmin, o qual, segundo a imprensa, é "pobre, tem escolaridade baixa e renda familiar de até dois salários mínimos" "184, além de ser, sobremodo no interior do estado, mais velho. O número de famílias que receberam o

184 “O paulista Ge-ral-do” por Julia Duailibi. Revista Piauí, n. 99, ano 8, 2014, dezembro, p. 22. 
Programa Bolsa Família também se mostrou relevante estaticamente para compreender a votação de Alckmin em 2010 e 2014, com o resultado esperado: os municípios que possuíam mais famílias beneficiárias do programa, que é ligado ao Partido dos Trabalhadores, votaram menos em Alckmin.

Não obstante os modelos tenham revelado a significância estatística de alguns indicadores socioeconômicos na compreensão da votação recebida pelo governador nos municípios, eles explicaram menos de $20 \%$ da variação dos dados, o que pôde ser observado pelo valor do $\mathrm{R}$ ajustado ao quadrado $\left(R^{2} a d j\right)$, gerado por cada um deles. Isso levou à combinação da análise quantitativa com a pesquisa qualitativa, para o entendimento dos resultados eleitorais.

Nesse sentido, foram trabalhados os outros três aspectos que compõem o quadro interpretativo das eleições de Alckmin. O primeiro deles se referiu à importância das alianças estabelecidas por ele e pelo PSDB para concorrer ao governo paulista. Ligado a esse ponto, foi analisada a facilidade do governador em congregar aliados e ao mesmo tempo cativar eleitores, o que foi feito a partir do estudo de sua imagem, personalidade e estilo de trabalho. Por último, sabendo que as consecutivas vitórias do PSDB culminaram na perda de seus rivais, foi avaliada a viabilidade das candidaturas ao governo de São Paulo do Partido dos Trabalhadores, como principal rival dos tucanos desde o final dos anos 90 .

O PSDB venceu as eleições de 1994 para o governo paulista com Mário Covas devido, em primeiro lugar, à conjuntura política posta no estado. O PMDB, que era até então o partido mais forte em São Paulo, perdeu vigor quando se desestabilizou durante o governo de Fleury Filho, devido a rusgas e acusações entre ele e seu antecessor, Orestes Quércia, motivadas por escândalos de corrupção. O PSDB, aproveitando-se da fraqueza interna e externa de seu principal adversário, fez uma campanha consistente, que somada a outros aspectos, resultou na vitória de Covas, liderança do partido.

A partir daí os tucanos mantêm o governo em São Paulo, totalizando mais de vinte anos de poder, graças também ao mérito do partido e de seus candidatos. Covas foi a liderança mais importante do partido desde sua criação até o início dos anos 2000. Era ele quem unificava o PSDB e intermediava suas alianças com outras siglas. Sendo um exímio negociador político, conseguiu, com a ajuda de Geraldo Alckmin, o apoio do PT quando disputou os segundos turnos em 1994 e 1998. Com sua morte em 2001, o PSDB se viu 
órfão de seu líder, o que abriu uma disputa interna pela herança do covismo. Embora o partido não tenha chegado a se dividir, como foi o caso do PMDB nos anos 90, ele se fragilizou, e isso foi, em parte, o que permitiu que o petista José Genoíno disputasse, de forma inédita, o segundo turno com Geraldo Alckmin em 2002.

Alckmin, a contragosto de alguns psdebistas, herdou o lugar que era de Covas em São Paulo, apesar de nunca tê-lo substituído como a principal liderança do PSDB, lugar que até hoje não pertence a ninguém do alto comando. "Geraldinho", como era chamado por Covas, herdou de seu antecessor e padrinho político a facilidade de agregar apoiadores. Entre os principais aliados sempre estiveram os democratas, ex-pefelistas. O DEM, além de ser um partido com lideranças importantes em São Paulo desde os anos 90, dotado de uma estrutura organizacional bastante difundida no estado, sempre comandou boa parte das prefeituras paulistas.

Sabe-se que é essencial para o candidato ao governo ter no município alguém próximo da população local que intermedeie sua relação com esta. Ressalta-se que o número de aliados do PSDB nas eleições em São Paulo teve um crescimento significativo desde 1990, o que demonstra a percepção dos apoiadores para a viabilidade das candidaturas tucanas. Com efeito, pode-se dizer que Alckmin foi beneficiado tanto pelo aumento do número de aliados quanto pela importância destes em São Paulo, já que isso significa a maximização da força de sua candidatura a governador.

É certo que o jeito atencioso e cordial de Alckmin com seus pares facilita a formação de alianças. Em suas viagens frequentes pelo interior do estado, faz questão de informar aos prefeitos sobre sua chegada e gosta de estar bem informado acerca das obras em andamento nos municípios. O governador investe cotidianamente no trabalho de congregar aliados, desde a década de 90, quando foi presidente do PSDB paulista. Sua cordialidade alcança, além de políticos, sobretudo o eleitorado.

Frequentemente cativa eleitores com seu jeito de bom moço e de contador de causos. Faz questão de ser visto como um membro do povo, e não da elite. Povo para o qual tem orgulho de lembrar a "identidade" do paulista, que remete aos tempos das bandeiras e à qual atribui parte de seu sucesso eleitoral. A exaltação do paulista trabalhador sempre está presente em seus discursos, assim como esteve naqueles pronunciados por Covas. Sua imagem de político provinciano, que se aproxima do eleitor entre um cafezinho e outro nas ruas, rendeu-lhe o apelido de "picolé de chuchu". No entanto, seu método para 
conquistar votos tem dado certo, e isso é inegável: é o governador com mais dias à frente do estado de São Paulo.

Acredita-se que suas vitórias também se relacionam à dificuldade dos partidos adversários de viabilizar suas candidaturas no estado, como é o caso do Partido dos Trabalhadores, principal partido de oposição aos tucanos a partir do final dos anos 90. O PT, desde quando concorreu pela primeira vez em 1982, nunca teve uma aceitação significativa entre o eleitorado paulista, com exceção de 2002, quando, devido à morte de Covas e ao crescimento nacional do partido, bem como à eleição de Lula para o Planalto, chegou até o segundo turno da disputa.

Ao contrário do PSDB paulista, que reúne, por meio de seus políticos, habilidades que lhe permite agregar aliados, o PT em São Paulo não possui lideranças locais que detenham a capacidade de negociação demonstrada por Covas ou Alckmin. É nesse ponto que entra Lula, líder nacional, que, tendo o poder de escolher o candidato em São Paulo, especialmente a partir dos anos 2000, funcionou como um mediador entre seu partido e os demais no estado. Além disso, colocou-se - e foi colocado - como cabo eleitoral, tentando fazer valer suas escolhas, ou melhor, suas criações ou invenções. O caso mais recente foi o de Alexandre Padilha em 2014.

Nessas últimas eleições, o mau resultado do PT foi mais alarmante porque nessa ocasião o partido não conseguiu obter vantagem eleitoral em face do candidato à reeleição, Geraldo Alckmin, que enfrentou severas críticas à sua gestão, decorrentes, principalmente, da crise da água que se alastrou pelo estado. Pode-se dizer que a rejeição ao PT, especialmente nessa eleição, além de fatores internos, relacionou-se, em parte, à disseminação midiática de comentários e opiniões que hostilizavam o partido e, em contrapartida, preservavam o governo do estado.

Conclui-se que Geraldo Alckmin tem suas vitórias relacionadas não somente à estrutura socioeconômica ou à conjuntura política correspondente a cada eleição, mas também ao fato de ser um político nato. Não é um showman, como Lula, e também não possui o carisma do líder petista. Apesar disso, conquistou o eleitorado paulista por representar, em larga medida, uma espécie que parece em extinção na política brasileira. Na contramão dos escândalos que desmoralizam parte significativa da classe política como ocorreu com o próprio Lula -, Alckmin cultiva uma imagem de político humilde, atencioso, católico praticante e com princípios familiares. 
Suas características é que o fazem conseguir transitar com facilidade e eficácia entre todos os tipos de pessoas. Acusado de estar sempre em cima do muro, devido ao seu tom conciliador, é generoso com seus aliados e evita falar mal de seus adversários publicamente.

Alckmin parece ter descoberto o segredo de seu ofício enquanto político, que, como anota Tocqueville,

“(...) consiste em envolver-se continuamente entre os seus, e mesmo entre os adversários, em apresentar-se, em prodigalizar-se todos os dias, em abaixar-se e elevar-se a cada instante para atingir todos os níveis de inteligência, em discutir, em argumentar sem descanso, em repetir mil vezes as mesmas coisas sob diferentes formas e em animar-se eternamente diante dos mesmos objetos" (TOCQUEVILLE, 2011, p. 126). 


\section{REFERÊNCIAS BIBLIOGRÁFICAS}

ACERVO DO JORNAL ESTADÃO. <http://acervo.estadao.com.br/>. Acesso em: meses de abril e maio de 2016.

ACERVO DO JORNAL FOLHA DE S. PAULO $<$ http://acervo.folha.uol.com.br/?cmpid=menulate>. Acesso em: meses de abril e maio de 2016.

ALMEIDA, A.; LOPEZ, F. Legisladores, captadores e assistencialistas: a representação política no nível local. Brasília: Instituto de Pesquisa Econômica Aplicada, 2012.

AMES, B. Os entraves da democracia no Brasil. Rio de Janeiro: Editora FGV, 2003.

BAQUERO, M. A vulnerabilidade dos partidos políticos e a crise da democracia na América Latina. Porto Alegre: Editora da UFRGS, 2000.

BARTOLINI, S.; MAIR, P. Identity, Competition, and Electoral Availability: The Stabilization of European Electorates (1885-1985). Cambridge: Cambridge University Press, 1990.

BAUMAN, Z. Em busca da política. Rio de Janeiro: Zahar, 2000.

BELCHIOR, A. M. Confiança nas Instituições Políticas. Lisboa: Fundação Francisco Manuel dos Santos, 2015.

BELLOTTO, H. L. Autoridade e conflito no Brasil colonial: o governo do Morgado de Mateus em São Paulo (1765-1775). 2 ed. São Paulo: Alameda, 2007.

BEYME, K. von. Los Partidos Políticos em las Democracias Occidentales. Centro de Investigaciones Sociológicas: Madri, 1986.

BEZERRA, M. O. Em nome das "bases": política, favor e dependência pessoal. Rio de Janeiro: Relume-Dumará - NUAP, 1999.

BOFF, F. "Entrevista com Marshall McLuhan (1977) - Legendado". Disponível em: <https://www.youtube.com/watch?v=fvRMpS-aGLE>. Acesso em 6 de março de 2016.

BOURDIEU, P. Sobre o Estado: Cursos no Collège de France (1989-92). 1ạ ed. São Paulo: Companhia das Letras, 2014.

BRAGA, M. do S. S. "Organização partidária e seleção de candidatos no estado de São Paulo". Opinião Pública, Campinas, v. 14, n. 2, p. 454-485, novembro, 2008.

BRUNO, E. S. História e tradições da cidade de São Paulo. Rio de Janeiro: J. Olympio, 1953.

CARREIRÃO, Y. S. "Ideologia e partidos políticos: um estudo sobre coligações em Santa Catarina". Opinião Pública, Campinas, v. 12, n. 1, p. 136-163, abril/maio 2006.

CARVALHO, N. R. E no início eram as bases: geografia política do voto e comportamento legislativo no Brasil. Rio de Janeiro: Revan, 2003. 
CERVI, E. U. "Produção legislativa e conexão eleitoral na assembleia legislativa do estado do Paraná". Revista de Sociologia Política, Curitiba, v. 17, n. 32, p. 159-177, fev. 2009.

CHAPOLA, R.; TOMAZELA, M. "Prefeitos do PMDB deixam Skaf e dão apoio a Alckmin". O Estado de S. Paulo. Publicado em 30 de setembro de 2014. Disponível em: <http://politica.estadao.com.br/noticias/eleicoes, prefeitos-do-pmdb-deixam-skaf-e-daoapoio-a-alckmin-imp-,1568212>. Acesso em: 12 de fevereiro de 2016.

CLARK, T. N., LIPSET, S. M., e RAMPEL, M. "The declining political significance of class". In: CLARK, T., e LIPSET, S. (orgs), The Breakdown of Class Politics: a Debate on Post-Industrial Stratification, Baltimore: The Johns Hopkins University Press, p. 77-104, 2001.

CONGRESSO EM FOCO. Disponível em: 〈http://congressoemfoco.uol.com.br/>. Acesso em: 9 de novembro de 2016.

COUTINHO, M. "Promotoria já pediu ao menos dez vezes a prisão de executivos do cartel de trens em SP". O Estado de S. Paulo. Publicado em 14 de março de 2016. Disponível em: <http://politica.estadao.com.br/blogs/fausto-macedo/promotoria-ja-pediu-dez-vezes-aprisao-de-11-executivos-do-cartel-de-trens-em-sp/> . Acesso em: 5 de abril de 2016.

DALTON, R. "Political cleavages, issues and electoral change". In: LEDUC, L., NIEMI, R., e NORRis, P. (orgs.), Comparing Democracies: Elections and Voting in Global Perspective, Londres: Sage Publications, p. 319-342, 1996.

DATAFOLHA. Disponível em: 〈http://datafolha.folha.uol.com.br/>. Acesso em 15 de janeiro de 2016.

DCMARTE. "Programa Eleitoral | Biografia | Mercadante - 2010". Disponível em: <https://www.youtube.com/watch? $\mathrm{v}=\mathrm{MnBuo} d \mathrm{dV} 1 \mathrm{x} 4$ > . Acesso em: 3 de março de 2016.

DISCURSO DE POSSE DE GERALDO ALCKMIN EM 2002. Disponível em: <www.casacivil.sp.gov.br/biblioteca-ccivil/DiscursosFile.asp?id=12>. Acesso em: $10 \mathrm{de}$ maio de 2016.

DISCURSO DE POSSE DE GERALDO ALCKMIN EM 2011. Disponível em: $<$ http://www1.folha.uol.com.br/poder/853674-leia-integra-do-discurso-de-posse-degeraldo-alckmin-no-palacio-dos-bandeirantes.shtml>. Acesso em: 10 de maio de 2016.

DISCURSO DE POSSE DE GERALDO ALCKMIN EM 2015. Disponível em: <http://www.saopaulo.sp.gov.br/spnoticias/lenoticia2.php?id=239110>. Acesso em: $10 \mathrm{de}$ maio de 2016.

DOGAN, M. "Class, religion, party: triple decline of electoral cleavages in Western Europe”. In: KARVONEN, L. e KUHNLE, S. (orgs.), Party Systems and Voter Alignments Revisited, Londres: Routledge, p. 93-114, 2001.

DUAILIBI, J. "O paulista Ge-ral-do: quem é o político católico e caipira que assume pela quarta vez o governo de São Paulo"”. Revista Piauí, n. 99, ano 8, dezembro, p. 24, 2014 
- "A nova sinfonia paulistana: como a rádio Jovem Pan se reinventou ao dar voz para o sentimento antipetista em São Paulo". Revista Piauí, n. 106, ano 9, julho, p. 16-25, 2015.

DUVERGER, M. Os Partidos Políticos. São Paulo: Zahar, 1970.

ESTATUTO DO PARTIDO DA SOCIAL DEMOCRACIA BRASILEIRA (PSDB).

Disponível em: <http://static.psdb.org.br/wpcontent/uploads/2016/02/Estatuto\%202015_12_final.pdf.> Acesso em: 6 de maio de 2016.

FREIRE, A. Modelos de Comportamento Eleitoral. Oeiras: Celta Editora, 2001.

FUNDAÇÃO MÁRIO COVAS. Disponível

<http://www.fundacaomariocovas.org.br/>. Acesso em: 10 de maio de 2016.

FUNDAÇÃO PERSEU ABRAMO. "Nacional: Entrevista com Eduardo Suplicy - A vitória da transparência". Disponível em: <http://csbh.fpabramo.org.br/o-quefazemos/editora/teoria-e-debate/edicoes-anteriores/nacional-entrevista-com-eduardosuplicy-vit>. Acesso em: 14 de março de 2016.

FUNDAÇÃO SISTEMA ESTADUAL DE ANÁLISE DE DADOS (SEADE). Disponível em: 〈http://www.seade.gov.br/>. Acessado em 7 de agosto de 2016.

GASPAR, J.; ANDRÉ, I. “Portugal geografia eleitoral: 1975 e 1987”. In: COELHO, M. B. (org.), O Sistema Político e Constitucional, Lisboa, Instituto de Ciências Sociais, 1989.

GAZETA ONLINE. Disponível em: 〈http://www.gazetaonline.com.br/>. Acesso em: 18 de fevereiro de 2016.

GIDDENS, A. A constituição da sociedade. 2a ed. São Paulo: Martins Fontes, 2003.

GOMBATA, M. "Em Hortolândia, o PSDB não tem vez”. Carta Capital. Publicado em 14 de outubro de 2014. Disponível em: <http://www.cartacapital.com.br/politica/emhortolandia-o-psdd-nao-tem-vez-7597.html.> Acesso em: 2 de fevereiro de 2016.

GRAHAM, M. Diário de uma viagem ao Brasil. São Paulo: Companhia Editora Nacional, 1956.

HOUT, M., BROOKS, C., e MANZA, J. "The persistence of classes in post-industrial societies. In: CLARK, T., e LIPSET, S. (orgs), The Breakdown of Class Politics: a Debate on Post-Industrial Stratification, Baltimore: The Johns Hopkins University Press, p. 55-75, 2001.

HORÁRIO ELEITORAL 2014. "Horário Eleitoral - Governador SP 20/08/14 - Geraldo Alckmin (PSDB) - Primeiro programa”. Disponível em: $<$ https://www.youtube.com/watch?v=afkCL4ThW34>. Acesso em 29 de maio de 2016.

INGLEHART, R. "The changing structure of political cleavages in Western society". In: DALTON, R., FLANAGAN, S., e BECK, P. (orgs.), Electoral Change in Advanced Industrial Societies: Realignment or Dealignment? Princeton: Princeton University, p. 2569, 1984. 
INSTITUTO BRASILEIRO DE GEOGRAFIA E ESTATÍSTICA (IBGE). Disponível em: $<$ http://www.ibge.gov.br/home/>. Acessado em 7 de agosto de 2015.

INSTITUTO DE OPINIÃO PÚBLICA E ESTATÍSTICA (IBOPE). Disponível em: $<$ http://www.ibope.com.br/pt-br/Paginas/oquevoceprocura.aspx $>$. Acesso em: 8 de novembro de 2015.

JACOB, C. R.; HEES, D. R.; WANIEZ, P.; BRUSTLEIN, V. "Eleições presidenciais de 2002 no Brasil: uma nova geografia eleitoral?" Revista ALCEU, Rio de Janeiro, v. 3, n. 6, p. 287-327, jan./jun. 2033.

JOVEM PAN. Disponível em: 〈http://front1.jovempan.com.br/>. Acesso em: 15 de maio de 2016.

KINZO, M. D. "Os partidos no eleitorado: percepções públicos e laços partidários no Brasil”. Revista Brasileira de Ciências Sociais, São Paulo, vol. 20, n. 57, fev. 2005.

KIRCHHEIMER, O. "The transformation of the Western European party systems". In: LaPALOMBARA, J.; WEINER, M (orgs.), Political parties and political development. New Jersey: Princeton University Press, p. 177-200, 1966.

LAMOUNIER, B. "Comportamento eleitoral em São Paulo: passado e presente". In: CARDOSO, F. H., LAMOUNIER, B. Os partidos e as eleições no Brasil. Rio de Janeiro: Paz e Terra, 1975.

. “O voto em São Paulo, 1970-1980”. In: LAMOUNIER, B. (org.). Voto de desconfiança, eleições e mudança política no Brasil: 1970-1979. São Paulo: Vozes, 1980.

LEONARDI, T. "Programa Geraldo Alckmin Noite 27/10/2006". Disponível em: <https://www.youtube.com/watch?v=10wZQm5emno>. Acesso em: 4 de maio de 2016.

LIMA, V. A. de. "Televisão e política: hipótese sobre o primeiro turno da eleição presidencial de 1989”. Mídia Política: teoria e prática. São Paulo: Editora Perseu Abramo, p. 213-249, 2001.

LIMONGI, F.; GUARNIERI, F. "Competição partidária e voto nas eleições presidenciais no Brasil”. Opinião Pública, Campinas, v. 21, n. 1, p. 60-86, abril 2015.

LIMONGI, F.; MESQUITA, L. "Estratégia partidária e clivagens eleitorais: as eleições municipais pós-redemocratização". In: KOWARICK, L.; MARQUES, E. São Paulo: novos percursos e atores (sociedade, cultura e política). São Paulo: Ed. 34, Centro de Estudos da Metrópole, 2011.

LIPSET, S. M.; ROKKAN, S. Party Systems and Voter Alignments, Nova Iorque, Free Press, 1967.

LISI, M. Os partidos políticos em Portugal: continuidade e transformação. Coimbra: Almedina, 2011.

MACEDO, J. B. de. Portugal e economia "pombalina". Temas e hipóteses. Revista de História, São Paulo, 5(19): 81-101, jul. set. 1954. 
MAIA, J. "Geografia eleitoral e manutenção do poder: a importância das bases eleitorais para a reeleição do executivo estadual". Paraná Eleitoral: revista brasileira de direito eleitoral e ciência política, Curitiba, v. 3, n. 3, p. 407-436, dezembro 2014.

MANIN, B. “As metamorfoses do governo representativo". Revista Brasileira de Ciências Sociais, São Paulo, ano 10, n. 29, 1995.

MARCONDES, C. "José Genoíno e o Araguaia". Carta Capital. Publicado em 09 de dezembro de 2009. Disponível em: <http://www.cartacapital.com.br/politica/jose-genoinoe-o-araguaia>. Acesso em: 21 de maio de 2016.

MARQUES, E. C. Redes sociais, instituições e atores políticos no governo da cidade de São Paulo. São Paulo: Annablume: Fapesp, 2003.

MARTINS, R. ""Precisamos de mais médicos imediatamente", diz Padilha". Carta Capital. Publicado em 13 de julho de 2013. Disponível em: $<$ http://www.cartacapital.com.br/saude/precisamos-de-mais-medicos-imediatamente-dizpadilha-2122.html >. Acesso em: 6 de março de 2016.

MUNARI, C. "DEM e PMDB apoiam Alckmin em 2010 para ter apoio tucano a Kassab". G1. Publicado em 24 de abril de 2008. Disponível em: <http://g1.globo.com/Noticias/Politica/0,,MUL424988-5601,00-

$\mathrm{DEM}+\mathrm{E}+\mathrm{PMDB}+\mathrm{APOIAM}+\mathrm{ALCKMIN+EM+PARA}+\mathrm{TER}+\mathrm{APOIO}+\mathrm{TUCANO}+\mathrm{A}+\mathrm{KAS}$ SAB.html>. Acesso em: 4 de abril de 2016.

MUSEU DO TRABALHADOR DO CAMPO. "Confronto em Leme termina com morte de boia-fria". Disponível em: <https://www.youtube.com/watch?v=EmFyyXX7jdQ>. Acesso em: 13 de fevereiro de 2016.

NICOLAU, J. Dados eleitorais do Brasil, 1982 a 1996. Rlio de Janeiro: Ed. Revan, 1998. pp. 689-720, 2006.

"O sistema eleitoral de lista aberta no Brasil". Dados [online], vol.49, n.4,

NIEWBEERTA, P. "The democratic class struggle in postwar societies: Traditional class voting in twenty countries, 1945-1990". In: CLARK, T., e LIPSET, S. (orgs), The Breakdown of Class Politics: a Debate on Post-Industrial Stratification, Baltimore: The Johns Hopkins University Press, p. 121-135, 2001.

OAKESHOTT, M. "On Being Conservative". In: Rationalism in Politics and Other Essays. Indianapolis: Liberty Fund, 1991.

OLIVEIRA, M. "Skaf compara IPTU a CPMF; Haddad diz que Fiesp quer prejudicar SP". G1. Publicado em 19 de dezembro de 2013. Disponível em: <http://g1.globo.com/saopaulo/noticia/2013/12/skaf-compara-iptu-cpmf-haddad-diz-que-fiesp-quer-prejudicarsp.html>. Acesso em: 23 de maio de 2016.

OLIVEIRA, M. A. "Tese de repetir candidato reforçou escolha de Mercadante em SP". G1. Publicado em 24 de abril de 2010. Disponível em: $<$ http://g1.globo.com/politica/noticia/2010/04/tese-de-repetir-candidato-reforcou-escolhade-mercadante-em-sp.html>. Acesso em: 17 de abril de 2016. 
PASQUINO, G. Sistemas Políticos Comparados. Cascais: Principia, 2005.

PERES, P. S. "Institucionalização do sistema partidário ou evolução da competição? Uma proposta de interpretação econômica da volatilidade eleitoral". Opinião Pública, Campinas, v. 19, n. 1, p. 21-48, junho 2013.

PIERUCCI, A. "São Paulo 92, a vitória da direita”. Novos Estudos, São Paulo, n. 35, 1993.

RAMOS, U. "Eleições 1998: Mário Covas X Paulo Maluf”. Disponível em: $<$ https://www.youtube.com/watch?v=V23Cgj6Po-8>. Acesso em 24 de abril de 2016.

ROCHA, C. "Eleitorado paulistano: continuidades e descontinuidades entre 1947 e 2004 ". Paraná Eleitoral: revista brasileira de direito eleitoral e ciência política, Curitiba, v. 1, n. 3, p. 249-278, 2012.

ROCHA M. M; BARBOSA, C. F. "Regras, incentivos e comportamento: as comissões parlamentares nos países do Cone Sul". Revista de Sociologia Política, Curitiba, v. 16, n. suplementar, p. 93-104, agosto 2008.

RÁDIOS. Disponível em: 〈http://www.radios.com.br/>. Acesso em: 30 de maio de 2016.

ROMA, C. R. "Política de alianças e desempenho eleitoral: um estudo sobre as estratégias de competição do PSDB, 1988-1998”. Petrópolis, XXIV Encontro Anual da ANPOCS, 2000 .

SAlLES, J. M. "O caseiro". Revista Piauí. Publicado em outubro de 2008. Disponível em: <http://piaui.folha.uol.com.br/materia/o-caseiro/>. Acesso em: 16 de março de 2016.

SAMUELS, D. "Determinantes do Voto Partidário em Sistemas Eleitorais Centrados no Candidato: Evidências sobre o Brasil’”. Dados, Rio de Janeiro, v. 40, n. 3, 1997.

SARTORI, G. Parties and Party Systems. New York: Cambridge University Press, 1976.

SECRETARIA DA FAZENDA DO ESTADO DE SÃO GOVERNO. Disponível em: <http://www.fazenda.sp.gov.br/ajustes/>. Acesso em: 4 de maio de 2016.

SENADO FEDERAL. Disponível em: 〈http://www12.senado.leg.br/hpsenado>. Acesso em: 31 de maio de 2016.

SIMÃO, Aziz. "O voto operário em São Paulo". Revista Brasileira de Estudos Políticos, Belo Horizonte, n. 1, 1956.

SOARES, G. A. D.; TERRON, S. "Dois Lulas: a geografia eleitoral da reeleição (explorando conceitos, métodos e técnicas de análise geoespacial)". Opinião Pública, Campinas, v. 14, n. 2, nov. 2008.

STORNI, T. P. Comportamento Eleitoral e Estratégia Partidária: uma análise espaçotemporal das eleições de SP e MG a partir dos conceitos de Inovação e Representação Sociais. 2010. 165 f. Dissertação (Mestrado em Economia), Centro de Desenvolvimento e Planejamento Regional da Faculdade de Ciências Econômicas, Universidade Federal de Minas Gerais, Belo Horizonte, 2010.

TOCQUEVILLE, A. de. Lembranças de 1848: as jornadas revolucionárias em Paris. São Paulo: Companhia das Letras, 2011. 
TRIBUNA DO NORTE. Disponível em: 〈http://www.tribunadonorte.com.br/>. Acesso em: 4 de março de 2016.

TRIBUNAL SUPERIOR ELEITORAL (TSE). Disponível em: 〈http://www.tse.jus.br/>. Acessado em 6 de agosto de 2015.

UNIÃO DA INDÚSTRIA DE CANA-DE-AÇÚCAR. Disponível em: http://www.unica.com.br/. Acesso em: 6 de abril de 2016.

VIOMUNDO. "Relembrando uma pesquisa na eleição paulista de 1998". Carta Capital. Publicado em 03 de agosto de 2010. Disponível em: <http://www.cartacapital.com.br/politica/relembrando-uma-pesquisa-na-eleicao-paulistade-1998>. Acesso em: 12 de maio de 2016.

WEBER, M. H. "Pedagogias de despolitização e desqualificação da política brasileira: as telenovelas da Globo nas eleições presidenciais de 1989”. Comunicação \& Política. São Paulo, ano 9, n. 11, abril-junho, p. 67-83, 1990.

WEBER, M. "Parlamento e governo na Alemanha reorganizada: sobre a crítica política do funcionalismo e do partidarismo". In: WEBER, M. Escritos Políticos. 1a ed. São Paulo: WMF Martins Fontes, 2014.

WEFFORT, F. C. "Raízes sociais do populismo em São Paulo". Revista Civilização Brasileira, Rio de Janeiro, ano 1, n. 2, 1965.

WHITELEY, P.; SEYD, P. High-intensity Participation: The Dynamics of Party Activism in Britain. USA: Ann Arbor, The University of Michigan Press, 2002.

ZUCCO, C. "The President's 'New" Constituency: Lula and the pragmatic vote in Brazil's 2006 presidential elections". Journal of Latin American Studies, 40(1), p. 29-49, 2008.

\section{APÊNDICE}

Tabela A.1. Estatísticas descritivas das variáveis utilizadas nos modelos de cada ano eleitoral

\begin{tabular}{|c|c|c|c|c|c|}
\hline Ano & Variáveis & Média & Desvio Padrão & Mínimo & Máximo \\
\hline \multirow{6}{*}{2002} & Anos de estudo (2000) & 6,447 & 0,777 & 4,230 & 9,760 \\
\hline & IDHM-dimensão renda (2000) & 0,671 & 0,050 & 0,520 & 0,867 \\
\hline & Índice de envelhecimento & 43,971 & 14,824 & 13,180 & 120,490 \\
\hline & Índice de Gini (2000) & 0,522 & 0,058 & 0,356 & 0,766 \\
\hline & Partido do prefeito & 0,565 & 0,496 & 0 & 1 \\
\hline & Número de empregos formais & 13346 & 133851 & 104 & 3360921 \\
\hline \multirow{4}{*}{2010} & Anos de estudo (2000) & 10,502 & 0,739 & 7,220 & 12,550 \\
\hline & IDHM-dimensão renda (2000) & 0,716 & 0,040 & 0,592 & 0,891 \\
\hline & Índice de envelhecimento & 63,489 & 22,007 & 22,140 & 158,730 \\
\hline & Índice de Gini & 0,459 & 0,057 & 0,334 & 0,686 \\
\hline
\end{tabular}




\begin{tabular}{|c|c|c|c|c|c|}
\hline & Partido do prefeito & 0,394 & 0,489 & 0 & 1 \\
\hline & Número de empregos formais & 19959,080 & 194441,780 & 159 & 4873339 \\
\hline & $\begin{array}{l}\text { Número de famílias que recebem } \\
\text { Bolsa Família }\end{array}$ & 1821,460 & 7377,690 & 24 & 166137 \\
\hline \multirow{7}{*}{2014} & IPRS-dimensão escolaridade (2012) & 55,192 & 7,512 & 35,000 & 77,000 \\
\hline & IPRS-dimensão riqueza (2012) & 35,913 & 6,800 & 14,000 & 59,000 \\
\hline & Índice de envelhecimento & 76,244 & 26,0550 & 30,130 & 194,690 \\
\hline & Índice de Gini (2010) & 0,459 & 0,057 & 0,334 & 0,686 \\
\hline & Partido do prefeito & 0,553 & 0,498 & 0 & 1 \\
\hline & Número de empregos formais & 21743,160 & 209479,43 & 186 & 5247898 \\
\hline & $\begin{array}{l}\text { Número de famílias que recebem } \\
\text { Bolsa Família }\end{array}$ & 1981,990 & 11534,770 & 27 & 281067 \\
\hline
\end{tabular}

* Variável binária, categorizada da seguinte forma: valor 0 caso o partido seja da base do governo e 1, caso o partido seja de oposição.

Fonte: elaboração da autora a partir dos dados do IBGE e SEADE. 